Florida International University

FIU Digital Commons

$7-2-2020$

\title{
The Legacies of Vagrancy Law in Contemporary Homelessness Regulation: A Global Historical and Ethnographic Examination of Tokyo, Japan and Kuala Lumpur, Malaysia
}

Rayna Marlene Rusenko

Florida International University, rruse001@fiu.edu

Follow this and additional works at: https://digitalcommons.fiu.edu/etd

Part of the Sociology Commons

\section{Recommended Citation}

Rusenko, Rayna Marlene, "The Legacies of Vagrancy Law in Contemporary Homelessness Regulation: A Global Historical and Ethnographic Examination of Tokyo, Japan and Kuala Lumpur, Malaysia" (2020). FIU Electronic Theses and Dissertations. 4474.

https://digitalcommons.fiu.edu/etd/4474

This work is brought to you for free and open access by the University Graduate School at FIU Digital Commons. It has been accepted for inclusion in FIU Electronic Theses and Dissertations by an authorized administrator of FIU Digital Commons. For more information, please contact dcc@fiu.edu. 


\section{FLORIDA INTERNATIONAL UNIVERSITY}

Miami, Florida

\section{THE LEGACIES OF VAGRANCY LAW IN CONTEMPORARY HOMELESSNESS REGULATION:

\begin{abstract}
A GLOBAL HISTORICAL AND ETHNOGRAPHIC EXAMINATION OF
\end{abstract} \\ TOKYO, JAPAN AND KUALA LUMPUR, MALAYSIA}

A dissertation submitted in partial fulfillment of the requirements for the degree of

DOCTOR OF PHILOSOPHY

in

GLOBAL AND SOCIOCULTURAL STUDIES

by

Rayna Marlene Rusenko 
To: Dean John F. Stack, Jr.

Green School of International and Public Affairs

This dissertation, written by Rayna Marlene Rusenko, and entitled The Legacies of Vagrancy Law in Contemporary Homelessness Regulation: A Global Historical and Ethnographic Examination of Tokyo, Japan and Kuala Lumpur, Malaysia, having been approved in respect to style and intellectual content, is referred to you for judgment.

We have read this dissertation and recommend that it be approved.

$\begin{array}{r}\text { Percy Hintzen } \\ \hline \text { Vrushali Patil } \\ \hline \text { Amy Bliss Marshell } \\ \hline \text { Matthew D Marr, Major Professor }\end{array}$

Date of Defense: July 2, 2020

The dissertation of Rayna Marlene Rusenko is approved.

Dean John F. Stack, Jr. Green School of International and Public Affairs

Andrés G. Gil Vice President for Research and Economic Development and Dean of the University Graduate School

Florida International University, 2020 
(C) Copyright 2020 by Rayna Marlene Rusenko

All rights reserved. 


\section{DEDICATION}

To everyone who shared their time and kindness.

To everyone needing more tolerant space. 
ABSTRACT OF THE DISSERTATION

THE LEGACIES OF VAGRANCY LAW IN CONTEMPORARY HOMELESSNESS

REGULATION: A GLOBAL HISTORICAL AND ETHNOGRAPHIC EXAMINATION

OF TOKYO, JAPAN AND KUALA LUMPUR, MALAYSIA

by

Rayna Marlene Rusenko

Florida International University, 2020

Miami, Florida

Professor Matthew D Marr, Major Professor

This dissertation illustrates how contemporary policy responses to homelessness in Tokyo, Japan and Kuala Lumpur, Malaysia have tapped into historically-entrenched policy ideas and institutions and been shaped by varied experiences with transnational policy networks from the mid-19th century. Using archival and ethnographic methods, I trace practices and policies pertaining to homelessness management while underscoring the unique yet globally-connected nature of local policy variations and impacts, including street-level experiences. I take a distinctly broad view of homelessness regulation to consider the criminal justice, welfare, and urban development policies that authorize street-level interventions by government and non-government actors. By focusing on Asian cities of varied developmental statuses, this research contributes to knowledge of —and reckoning with—the legacies of imperial and colonial politico-legal cultures in neoliberal governance beyond Euro-American contexts. 
This dissertation reveals the locally-situated ways in which homelessness has been (re)constructed across time and space as a problem of social and spatial disorder, ostensibly threatening spiritual and material modernity, defined differently across (post)colonial and (post)imperial contexts. This policy re/construction upholds what I identify as the legacy of vagrancy law: a delegitimization of homelessness across multiple policy fields, rendering it grounds for criminalization, eviction, public assistance disqualification, and political disenfranchisement. In highlighting street-level effects, the dissertation underscores how policy innovations across time, including welfarist approaches, incorporate terms constraining rights and socio-spatial mobility justified under legal frameworks classifying homelessness as an illegitimate and, hence, unprotected state of existence. I argue that truly democratic, humane solutions would require full legalization and public recognition of homelessness as not an aberration but an unexceptional variation in modern distributions of wealth and power. 


\section{TABLE OF CONTENTS}

CHAPTER

PAGE

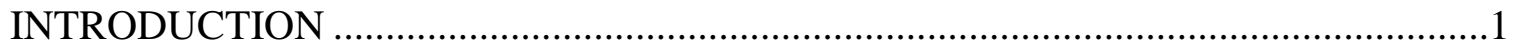

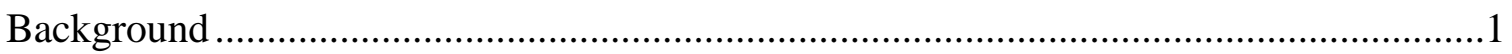

Statement of Problem and Methods ...............................................................................

The Constitution of Homelessness Regulation ..................................................................

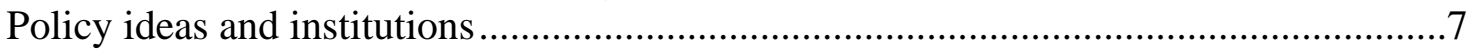

Neoliberal imperatives of social and spatial order ............................................................

Supportive, ambivalent, and punitive policy—versus freedom? .....................................14

Modern spatial and social development-and imperatives of order.............................17

Global history, compassionate acts, and power..........................................................19

Homelessness Today and Related Policy Regimes ..........................................................2.

Narrative Outline of the Dissertation...............................................................................35

Value of Research - Legacies and Democracy..................................................................37

CHAPTER 1. LITERATURE REVIEW AND METHODOLOGY ………………….......38

Social and Spatial Order in Global History ……………..................................................38

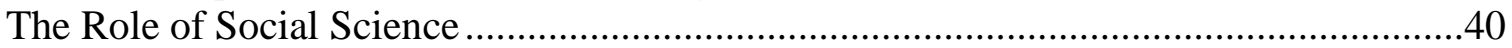

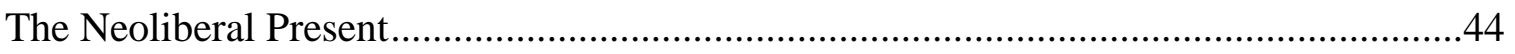

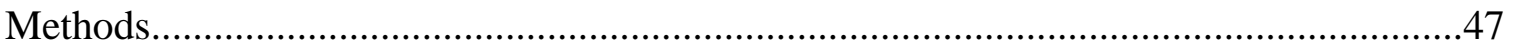

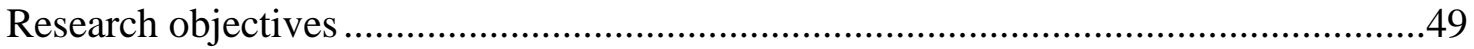

Research design and methods ..........................................................................50

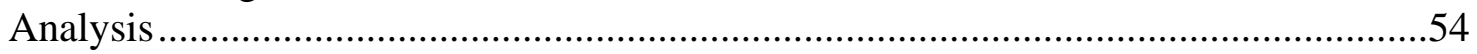

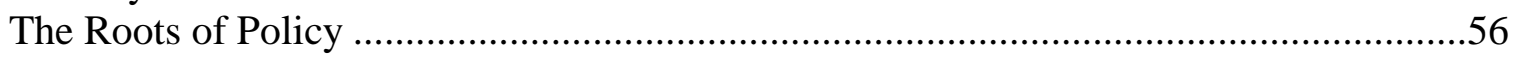

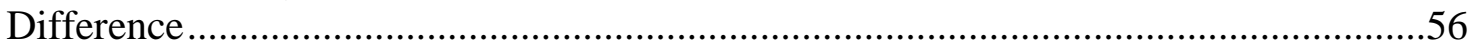

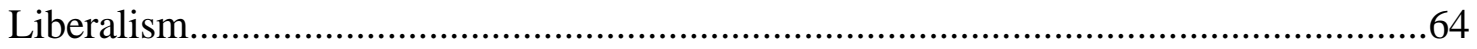

Police and the maintenance of order ……………................................................65

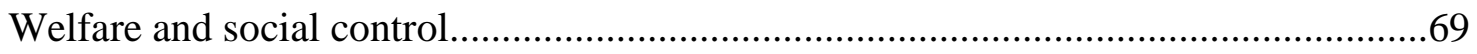

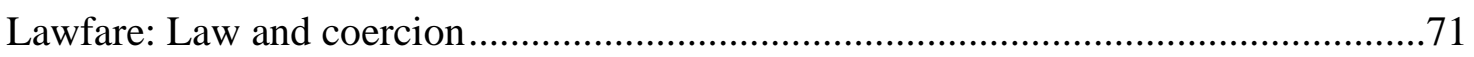

Discrimination, discretion, and homo sacer ...............................................................75

CHAPTER 2. IMPERATIVES OF CARE AND CONTROL ……………………….........

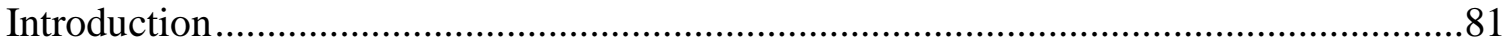

Homelessness Regulation, Policy Mobilities, and the Neoliberal Punitive Turn ...............83

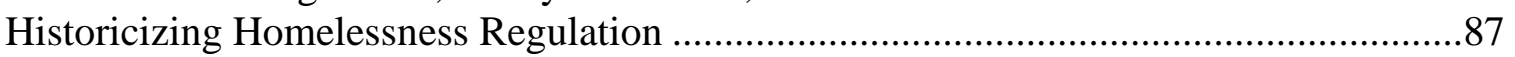

City Strategies and Policy Re/Formation in KL ............................................................89

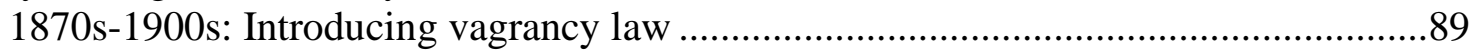

1910s-1930s: Refuge and repatriation........................................................................92

1940s-1960s: Preserving public order through compulsory care...................................94

1970s-1980s: Policing as social welfare services ..........................................................96

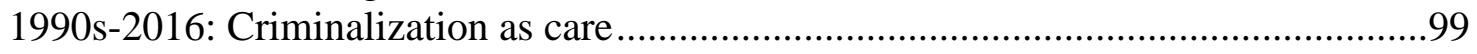

The Trajectory of Vagrancy Law..................................................................................102

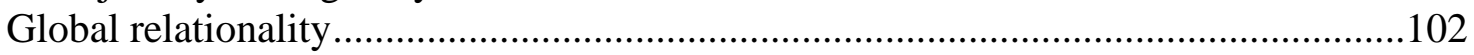

Territorial particularities ............................................................................................104 
A Malay(si)an paradigm of homelessness regulation ..................................................106

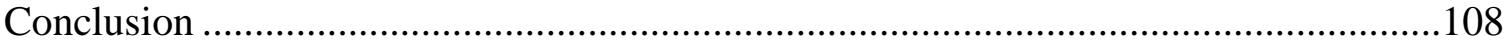

CHAPTER 3. NEOLIBERALISM'S IMPERIAL PAST ..............................................112

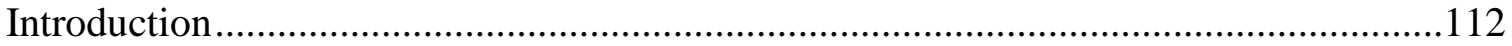

Why the Imperial Past? ..........................................................................................114

Tracing Imperial Formations (1868-2019) ……………...............................................119

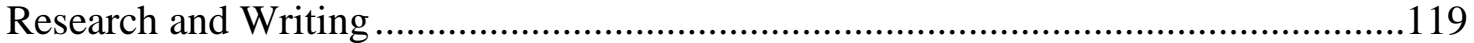

Imperial beginnings: Status containment to spatial containment (1868-1899) .............122

The private realm made public (1900-1929) ……………..........................................124

Welfare as empire's burden (1930-1945)...................................................................128

Making then insulating the universal state: discretion, self-reliance, devolution .........131

Turning the public realm private (1980-2019) ……………..........................................135

Neoliberalism's Imperial Past—and Present .............................................................140

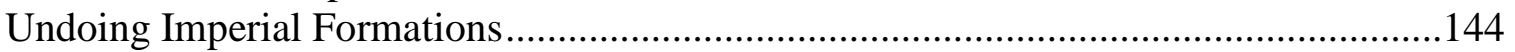

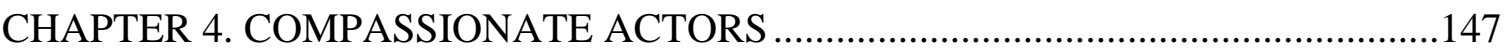

Introduction...........................................................................................................147

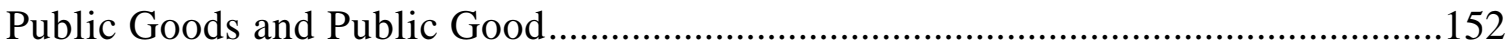

Framing the problem: Public agents, perspectives, and powers ...................................152

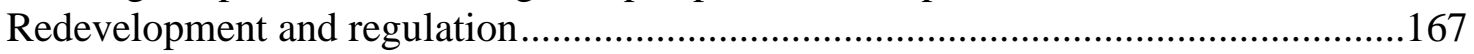

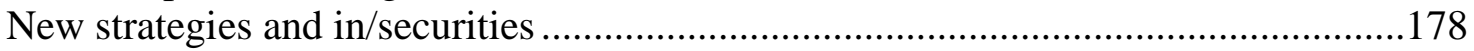

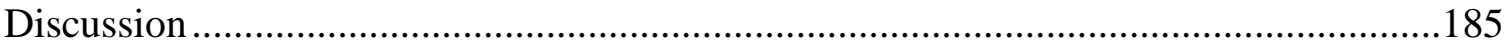

Imperiality — or democracy in socio-spatial governance ...........................................185

Socio-spatial security as a foundation of power.......................................................191

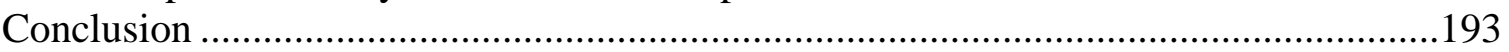

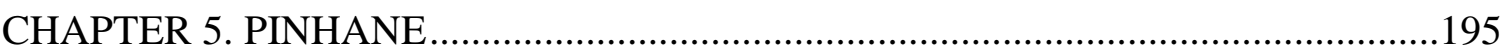

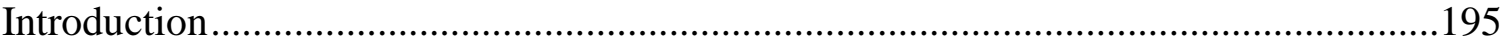

Between a Rock and a Hard Place .................................................................................197

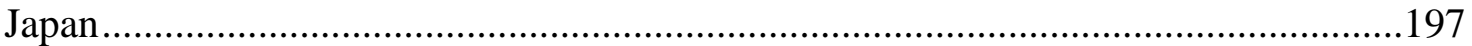

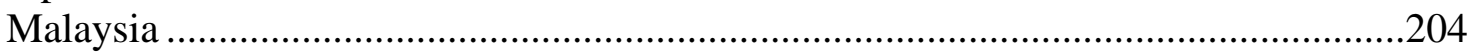

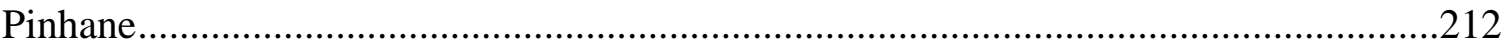

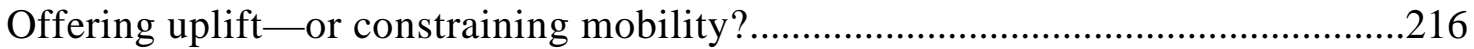

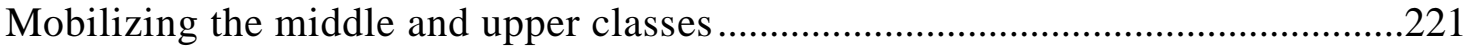

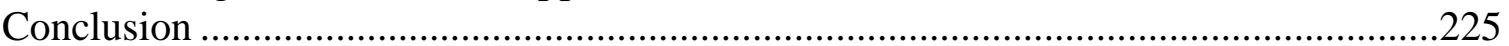

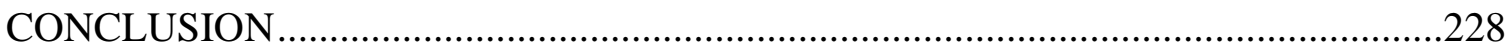

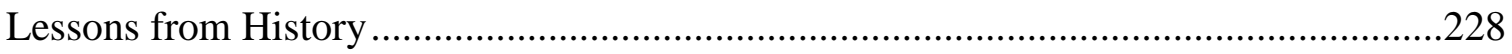

Neoliberal transformations.............................................................................228

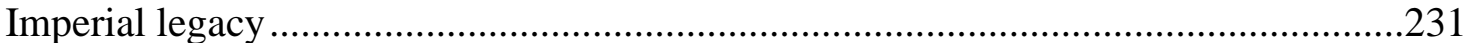

Global capitalism, Compassion, and Paternalism...................................................234

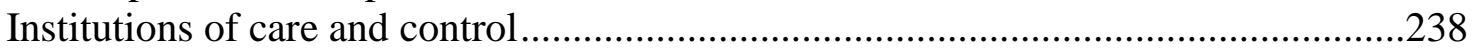

Capitalist divisions of labor and global homelessness .................................................241

Socio-spatial Governance: The Relation between Public Order and Welfare..................244

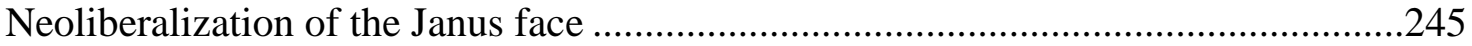


Animation across welfare-state and non-welfare-state infrastructure .......................248 The Unevenness of Democratic Power in the Present .................................................254

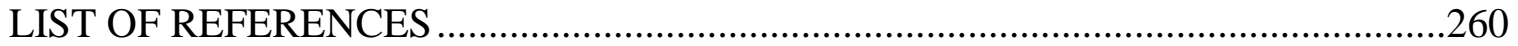

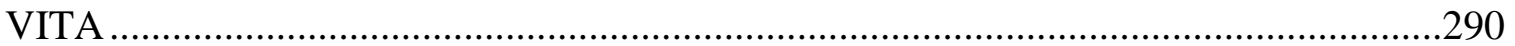




\section{TABLES}

TABLE

PAGE

Table 1. List of public, quasi-public, and civic organizations at my field sites..............10

Table 2. Government agencies and laws used to govern street homelessness.................28

Table 3. 2019 Tokyo Metropolitan count of homeless people, by type of facility........167

Table 4. 2019 Tokyo Metropolitan count of homeless people, shown by ward............168

Table 5. Number of people rescued annually, according to Ministry of Women data..172

Table 6. Institutions involved in public order and social welfare measures..................240 


\section{FIGURES}

\section{FIGURE}

PAGE

Figure 1. Article on homelessness: Mr Vagrant, Sir, you can't stay here ........................29

Figure 2. Results of 2005 survey showing highest concentrations of homelessness.........31

Figure 3. Newspaper article on Operasi Kutu Rayau, or vagrant operations ...................33

Figure 4. Map of Special Priority Development Areas for Urban Renaissance ...............149

Figure 5 Map of central Kuala Lumpur, showing the River of Life area .......................150

Figure 6. From the Homeless Measures Manual on Improving Park Management ........156

Figure 7. From the Homeless Measures Manual on Improving Park Management........157

Figure 8. Google map showing Anjung Singgah on Hang Lekiu Street ........................174

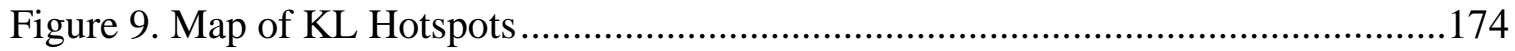




\section{PHOTOS}

PHOTO

PAGE

Photo 1. The Transition-to-Community-Life office in Yoyogi Park, 2005.......................153

Photo 2. Signs posted by Kuala Lumpur City Hall on Hang Lekiu Street. .......................162

Photo 3. Barriers placed to prevent people from resting beneath New Miyashita Park...170

Photo 4. Malaysia’s new Welfare Minister on the cover of CSR Malaysia.................175

Photo 5. Photos used by media and government to shame CSOs.........................175

Photo 6. Cahaya Suria Park in 2014, when it was known as a hotspot.....................176

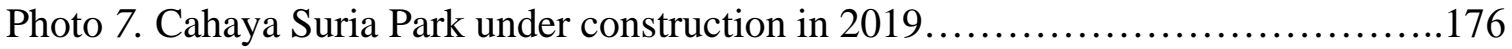




\section{INTRODUCTION}

\section{Background}

Before starting dissertation fieldwork in 2017, I knew the policy landscape of Tokyo and Kuala Lumpur well. I first developed an interest in homelessness as a matter of human rights after I first traveled to Tokyo as an exchange student in 1995. In late January 1996, I watched protests broadcast live on TV showing over 100 people from an underground encampment at Shinjuku Station resisting eviction by Tokyo metropolitan government officers and police. Three years later, when I returned to Tokyo for work, I consulted the Tokyo Resource Center for Human Rights of the Homeless to learn more and they suggested I spend time volunteering with the Soggidan day laborers' union in Sanya, Tokyo’s old day labor district—or yoseba.

Although Sōgidan started as a day laborers’ union in 1982, once homelessness_already common among day laborers_-became a more protracted problem across Tokyo in the 1990s, they shifted their focus to homelessness. Sōgidan organized a weekly kyōdō suiji (lit. collective kitchen, usually held outdoors) where people of mixed backgroundsincluding yoseba activists, unemployed and unsheltered laborers, university students, and other volunteers like myself-spent 5-10 hours each Sunday cutting vegetables, tending open fires, and chatting while preparing and distributing food for around 2000 people. Over my 10 years of engagement, I saw the introduction of new national regulations and metropolitan programs pertaining to homelessness, as I also learned in Sanya from a wide range of views on these policies and their mismatches.

I moved to Kuala Lumpur in 2011 to attend a master’s program in public policy as my experience with Sōgidan and other civil society organizations (CSOs) inspired me 
to learn more about how policy was made. In Kuala Lumpur, I found little in the way of rights-based or community-based movements addressing homelessness. Numerous CSOs distributed meals or ran drop-in centers, but these were almost exclusively charitable or altruistic in design, which is to say they were purposefully apolitical. I did, however, find Food Not Bombs-Kuala Lumpur, and began participating regularly in early 2011. Later that year, we launched an “outdoor kitchen” modeled after Sanya’s kyōdō suiji based on interest in creating an open space for people to spend more time together. At this time, homelessness was gaining salience, especially since a recent government count indicated nearly 1400 people were homeless in central Kuala Lumpur, which led Malaysia’s Prime Minister to announce that his office would fund Malaysia’s first transitional shelter. As a graduate student, I was able to develop research projects exploring federal policy like the Destitute Persons Act (DPA) and newly instituted models for aid like transitional shelters. I spent months observing programs at Malaysia’s first shelter and wrote my thesis on the DPA-based practice of conducting mass roundups, or “rescues", in place since 1965. Therefore, when government “rescues” became the subject of public scrutiny in 2014, Food Not Bombs and I were ready with information to share.

Over fifteen years in two cities, I witnessed the response of homeless and nonhomeless publics to the launch and implementation of various policies. In retrospect, I can see more clearly how political and economic interest in urban renewal and redevelopment had played a key role in the sustained interest of government agencies in tackling homelessness. I can also see more clearly the malicious effects that the manipulation of public interest has for democracy. Wherever public responses to homelessness have appeared punitive or insensitive in terms of rhetoric or action, public 
figures faced a backlash, particularly from organized groups in civil society. As a result, public officers and agencies have worked hard to distance themselves from unsympathetic stances and embrace supportive measures offering, for instance, free or low-cost shelter and housing. Moreover, public agencies have made way for civic groups to design, implement, oversee, or otherwise exercise power at the frontiers of policy. These policies, however, have also ferried less altruistic —and more dubious—ends, as public order measures and new modes of securitization tend to accompany changes. Consequently, the proliferation of material and economic aid has corresponded with the rise of anti-homeless urban architecture, such as the installation of "hostile" benches but also "green-washed" or "art-washed" landscaping planters and sculptures, and prohibitions against can-collecting and food distributions in both cities. At the extreme, there has also been a near-total eradication of tent cities in Tokyo and a doubling-down on programs of "rescue" and detention in Kuala Lumpur. Why exactly is this so?

Statement of Problem and Methods

Over the past two decades, Japanese and Malaysian government agencies have enacted new housing, welfare, and public order initiatives to achieve "zero homelessness" in their capital cities of Tokyo and Kuala Lumpur, respectively. Growing literature on homelessness regulation explores the influence of neoliberal strategies on measures like these (Beckett and Western 2010; Willse 2015), often attributing their spread to the political and economic influence of Euro-American hegemony (Wacquant 2009). However, few studies have investigated how historical processes have shaped contemporary homelessness governance, while fewer still look at countries beyond 
advanced Western contexts. Although both Tokyo and Kuala Lumpur adopted Britishinfluenced vagrancy laws in the 1880s, their regulatory regimes today operate in starkly different ways_-from each other and Euro-American models. How and why did different policy trajectories emerge? How have past policies and practices contributed to today's regulation? What do these trajectories mean for unsheltered persons and society more broadly today?

I answer these questions through global historical and ethnographic research on homelessness regulation in Tokyo and Kuala Lumpur from the late nineteenth century to the present. Owing to common origins, regulation in both cities incorporates Westerninfluenced penal and welfare strategies for managing homelessness. However, differences in the logics and institutions of these regulatory regimes also exist, thereby providing rich ground for exploring the legacies of global and local historical forces in regulation today. I argue that policy differences: 1) stem from ideational and institutional shifts reflecting particular (post)imperial and (post)colonial trajectories, and 2) are crucial for understanding contemporary policy change and experiences of homelessness.

This study will investigate four key empirical questions:

Q1. What changes emerged in policy codes and institutions governing homelessness in each city?

Q2. What conceptions of homelessness underpin such policies, and how do they shift over time?

Q3. How have conceptual frames, policy codes, and government institutions affected individual and collective experiences of homelessness in each city? 
Q4. What do these transformations reveal about socio-political drivers of homelessness regulation at global and local scales?

I collect data using ethnographic and archival research methods. The former centers on sites located near Chinatown in Kuala Lumpur and Sanya in Tokyo, which I have chosen for their significance as spaces of survival for unsheltered persons since the late nineteenth century. The latter concentrates on data illustrating ideas and institutions in homelessness governance. This includes archival materials like policy documents, legislative debates, and non-public communications to examine policy change and the influence of global and local forces therein at each locale. I take an ethnographic approach to archival research and treat the "archive as subject” (Stoler 2002). This approach supplements "hard" data on laws, practices, and institutions with the "soft" context of values, beliefs, and ideas that cohere these artifacts into a working system.

Ethnographic fieldwork builds on and extends archival findings by evidencing how past views and practices are, or are not, carried into contemporary policy. For example, I investigate how residual policy logics and structures shape policy changes and street-level experiences as they govern conditions for social inclusion via aid. I achieve this by spending time with people experiencing homelessness at each of my sites to observe interactions with enforcement officers and the artifacts of policy. I then expand on this by interviewing public officers responsible for policy formation and implementation, as well as people experiencing homelessness, to gain their insights on the objectives and effects of various policies. I take inspiration from scholars who have enriched homelessness studies by bringing to light "street-level" views of public policy 
through ethnographic research, combined with historical (Gill 2001; Gowan 2010; Stuart 2016) and comparative analysis (Marr 2015).

As I look into the form and effect of policy ideas and institutions in each city, historically and today, my aim is twofold. First, I aim to explore how raced, gendered, abled, and otherwise hierarchical conceptions of modernity have or have not been carried across time to the present, and whether and how such hierarchical conceptions underpin inequalities today. This is because both the realities of homelessness (i.e. demographics of people most vulnerable to homelessness) and implementation of policy are shaped by raced, classed, gendered, and otherwise inequitably ordered processes and structures of dis/advantage. In other words, I explore whether and how structural inequities exist in remedies to homelessness-itself an expression of inequities in society —and what their impacts are over time. To achieve this, first, I trace shifts in policy ideas, institutions, and street-level impacts in each city across political-economic changes over time. Second, I also identify legacies of empire in regulation, that is, the propagation of unequal power relations through policy and their relation to socio-political inequalities. My objective is to illustrate how social inequities can be propagated through policy over time.

For over a century, agencies in Japan and Malaysia have sought technical policy fixes for reducing or eliminating homelessness in their capital cities. In this dissertation, I offer a critical study of homelessness policy that underscores the central role of nonhomeless actors in creating and propagating problems through policy. As someone whose engagement with homelessness is limited almost exclusively to the streets, my concerns regarding the street-level effects of policy are in fact somewhat narrow. That is, by virtue of my focus on homelessness, I necessarily fail to include instances where people have 
exited or averted homelessness. My study is, in this regard, one of policy failure-and, more specifically, the myriad and specific ways in which homelessness policies fail users.

To date, conventional knowledge often pins the blame for policy failure—such as refusal to use shelters, remain employed, or sustain housing —on policy users. I aim to not only provide historicized insight into the roots of this bias, but I also aim to correct it. To start, I outline below how policy and law relate to homelessness in the context of each of my cities. I also explore each city's history of homelessness regulation, and why those histories remain relevant today.

The Constitution of Homelessness Regulation

Policy ideas and institutions

Policy is an instrument that renders particular ideas, events, and processes visible, while simultaneously casting a shadow on others. This can be seen in policy narratives, which are discursive strategies outlining the responsibility of public agencies and intended effects on target groups. The power of policy is also visible in how policy narratives emerge from and shape conventional thinking. I first recognized the influence of narratives in 2015, when I began to research the history and use of vagrancy laws in Japan. I was already aware that vagrancy statutes had been embedded in Japan's penal code by Taishō (1912-1926) and so I visited the Penal Archives in Nakano to search for more information. After entering the one-room library and presenting my research subject to the archivist, I was nearly turned away by a response I am now accustomed to. Once I stated I was interested in homelessness and its historical treatment, I was told I was in the 
wrong place: that homelessness in Japan is a matter of welfare so I should go look into welfare policy.

Over the coming weeks and years, as I looked into not only the history of vagrancy laws and arrests, but also interventions into homelessness by transportation, sanitation, and parks management departments, I heard this narrative repeatedly, including from senior public officers at national and metropolitan agencies and from young part-time staff at public libraries. In most cases, I have no reason to believe that people were trying to dissuade me from looking into policy outside of welfare. Also, the fact that I am both foreign (i.e. not Japanese) and a woman likely influenced people to think I would benefit from impromptu correction or advice. However, the predictability and uniformity of this response across multiple institutions underscored for me the effect of policy narratives on what we see and how we see it.

In Japan and Malaysia alike, policy narratives categorically identify homelessness as a matter of public welfare, and this necessarily deflects attention from its relation to other agencies and agents. This may even occur in spite of a narrator's good intentions, such as in advocating for better welfare provisions while failing to highlight concrete strategies for other fields. Moreover, the practice of collectively recognizing homelessness as a matter of humanitarian concern only in the context of welfare necessarily contributes to the objectification, or dehumanization, of people experiencing homelessness in other contexts addressed by non-welfare agencies.

Based on my experiences, I have deliberately taken a distinctly broad view of homelessness regulation to consider not only criminal justice and welfare but also urban development policies that authorize interventions by governmental and quasi- 
governmental agencies, including transportation, sanitation, and parks management departments. While I find that government agencies have been unanimous in presenting welfare and labor policies as instruments of singular importance in addressing homelessness, this narrative is both unhelpful and untrue. In actuality, the lives of people experiencing homelessness are profoundly impacted by decisions made across multiple agencies. Naturally, the full range could span policies as broad as education, immigration, credit and bankruptcy, urban planning, environmental conservation, and more. For the purposes of my research, I limit the scope of agencies and policies to those directly connected to interventions in public spaces by my fieldwork sites in the Taito and Shibuya Wards of Tokyo and the area spanning Central Market and Chow Kit in Kuala Lumpur (see Table 1, next page). I do this to offer a fuller record of how government responses to street homelessness in each city may or may not work together on the ground, along with the social, political, and material effects of particular policies and practices.

Neoliberal imperatives of social and spatial order

Policy narratives, or the rationale justifying interventions on the ground today, vary according to their local contexts — even where policies implemented appear identical to those elsewhere. When I returned to Tokyo in 2017, for example, the 2020 Tokyo Olympics featured prominently in explanations for various projects and programs under central, metropolitan, and ward-level agencies. This included Shibuya Ward's sudden decision to close Miyashita Park for redevelopment—-thereby pushing through tens of evictions-with a promise to reopen the park in the spring of 2020. Tokyo’s Summer 
Olympics have also been used to justify changes to zoning and use regulations, including those governing use of public and quasi-public land, to facilitate the development of

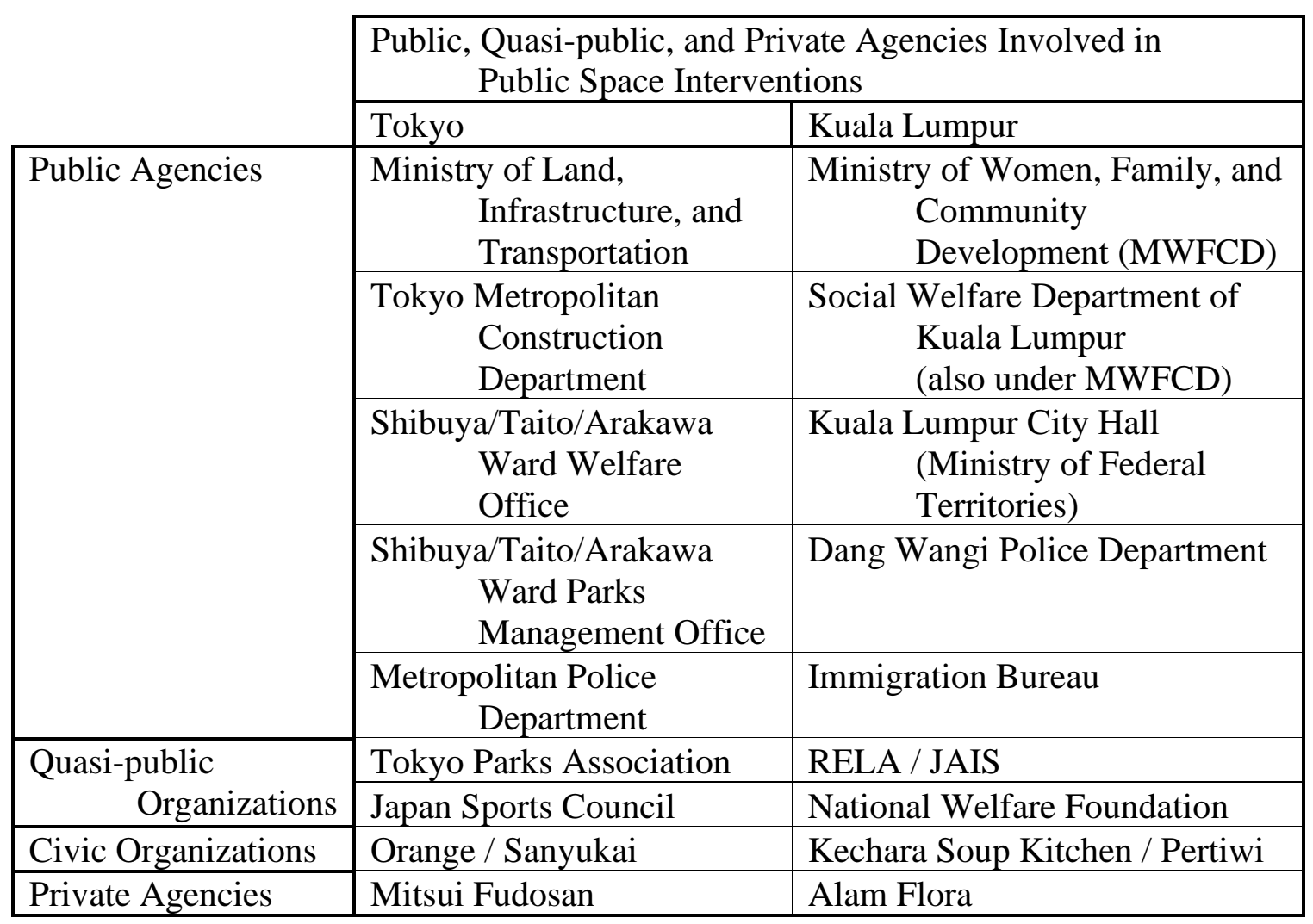

Table 1. List of public, quasi-public, and civic organizations at my field sites.

luxury hotels and high-rise residential suites across the city. National and metropolitan agencies assert that these developments offer short- and long-term benefits to the national economy by not only attracting Olympic visitors, but also increasing residential tourism and foreign direct investment into the future. In this way, the Olympics have acted as leverage for bolstering and often accelerating pre-existing ambitions for tackling homelessness in the interest of advancing economic growth via urban development and tourism. 
Consequently, although Shibuya's landscape has been continually in flux, large patches of the city have quickly become unrecognizable in just the last decade. Massive swathes of land are regularly cordoned off for construction, sometimes overnight, or unveiled as new streets, theaters, and shopping centers. The impact of this rapid, farreaching change on Shibuya's public space, and people relying on that space for survival, has been profound: in less than a decade, hundreds have been displaced from Miyashita Park, Yoyogi Park, and areas around the ward office and Shibuya Station. In Sanya, the pressures of development have manifested in a much slower, more circuitous fashion. Over this same span, neighborhoods surrounding the yoseba district are increasingly rebuilt or sporadically interrupted with new infrastructure like high-rise apartments, shopping centers, medical institutions, hotels, and new "green” park infrastructures. The neighborhood I resided in between August 2017 to February 2019 in Minami Senju sat next to a new high-rise premium residence for young families. Moreover, the high-rise was a ten-minute walk from a new three-story shopping center, but both buildings were still tucked into blocks of quaint one- and two-story homes inhabited by senior citizens who spent much of each day socializing in the street. Similarly, the nearby Asakusa area—home to Tokyo's historic Sensōji Temple, a patchwork of downtown streets, and scenic riverside parks—is being rapidly rebuilt for tourism. This bustle contrasted the lack of even a moderate push to invest in yoseba district infrastructure, as epitomized in late 2017 by the removal, rather than repair, of the awning on the old Iroha Shopping Arcade. The Arcade was once the commercial center of Tokyo's yoseba frequented by its thousands of laborers through the late twentieth century. However, as shops have gradually been shuttered and closed over the last two to three decades, the arcade 
primarily served as an evening resting spot for tens, if not over 100 people, who found themselves without shelter in the neighborhood. Now, without the awning, Sanya’s rough sleepers have lost their last defense against inclement weather.

My return to Kuala Lumpur—also after a 5-year absence—presented me with similar changes. The downtown area where I once coordinated the outdoor kitchen— known for its landmark: the Segi College building on Hang Lekiu Street—had changed little except for two new cafes about $100 \mathrm{~km}$ away on a parallel street. In the evenings, after the College and its surrounding businesses began to close, over 100 persons would gather in the area before CSOs came each night bringing food, clothes, and other aid. The two new cafes seemed to have young owners whose affluent taste contrasted the neighborhood's gritty nature. That is, the area's prewar-era Chinese shoplots were picturesque but overrun by cockroaches, rats, stray cats, and aggressive vegetation covering the buildings. In fact, the smell of death hugged the buildings as the small bodies of feral animals and pests rotted in the nooks of crumbling infrastructure. The older generation of shoplot owners have repurposed building for two enterprises: on the ground floor, they keep simple diner-style restaurants or print shops catering to college students, and partition second-floor space into bed-sized rooms, which can be rented for 20 Ringgit per night to single parents, migrant laborers, and other people working—or seeking work—in minimum-wage or illicit jobs. The new cafés, located at the neighborhood's edge, have been renovated so that brick fabrics still look decayed, but are in fact cleaned and stabilized. This aesthetic of sanitized dilapidation is now popular among leisure-class aficionados of authentic urbanism and KL's cultural heritage. Inside, 
customers easily spend 30 Ringgit each on drinks and delicacies like roselle-infused coffee and chocolate-hazelnut cake.

However, the gamble made by the café owners is a fair one. On either side of Hang Lekiu Street is Chinatown to the east and Kuala Lumpur's oldest mosque and famed attraction Masjid Jamek to the west. Also, there are historic museums, colonial buildings, and Merdeka (Independence) Square just a ten-minute walk away. That is, considering Kuala Lumpur's compact size and remarkable history, all tourists end up here. All a café would need is a strong online presence to attract presumably endless streams of new customers_-and the new cafes seem to be doing well so far.

Moreover, the names of transnational companies, including Mitsui Fudosanknown for redevelopment of Shibuya’s Miyashita Park—are highly visible throughout central KL as they appear on billboards and construction sites that are now popping up throughout the central district. Advertisements promise condos, shopping centers, office towers, hotels, and other buildings destined to bring more wealth to the capital. Against that background, the new sidewalks, bridges, bus stops, and mist machines installed by my fieldwork site appeared quite modest. In both Tokyo and Kuala Lumpur, the drive to bring in foreign business and investment, including tourist activity, has visibly accelerated development throughout each city—and I was stunned by how this "boom” contrasted the inertia or inactivity of even just upkeep for spaces in by each city’s homeless hub. 
Supportive, ambivalent, and punitive policy—versus freedom?

Policies that typically govern public and social order have an array of supportive, ambivalent, and punitive effects rooted in imperial and colonial systems of treating offenders with punishment or care (Garland 1985, 2001; DeVerteuil 2006). After I reacquainted with Kuala Lumpur in my first weeks, I suddenly realized that conditions in Tokyo and Kuala Lumpur had flipped—at least relative to my earlier stays. Between 2001 and 2011, I thought of Japan’s approach to homelessness as predominantly supportive, owing to its relatively generous welfare-state infrastructure and the absence of criminal treatment ${ }^{1}$ of homelessness (both unlike the US). Consequently, in Tokyo, people experiencing homelessness were able to erect and/or stay in tents and other makeshift abodes in some public spaces. However, during my stay in Kuala Lumpur between 2011 and 2014, I thought of measures addressing homelessness as more harsh owing to the meagre extent of state aid and the use of regularly scheduled mass roundups and compulsory detention to clear the streets. Intuitively, I once thought that people experiencing homelessness in Tokyo had more options, autonomy, and resources available to them; this is, I think, what many people presume the function and effect of welfare systems would be. However, by the end of 2019, I no longer felt the same way.

In late 2018, prior to my arrival in Kuala Lumpur, the Kuala Lumpur Welfare Department and Kuala Lumpur City Hall had halted their night-time anti-vagrancy roundups — albeit unannounced—likely owing to the entry of a new ruling party into government. Over time, as people sleeping rough sensed that roundups had stopped, at

\footnotetext{
${ }^{1}$ Anti-vagrancy statutes in Japan’s Minor Offenses Act remain in effect, from 1948 to the present.
} 
least for a short while, they began congregating more openly on the streets and socializing without as much self-consciousness or fear. Seeing people come together in large numbers and freely use public space reminded me of how encampments once existed and felt in Tokyo. When I first started living in Tokyo, until policy designed to eliminate encampments was enacted in 2004, anywhere from five to 20 to over 100 tents could be easily found in open areas, especially large parks. Today, however, encampments have largely disappeared as regular patrols and other forms of rigid security prohibit settlement, while street homelessness too is rendered less visible by antihomeless measures, such as the criminalization of can-collecting and the installation of ‘hostile’ benches and landscaping planters to reduce space for rest.

While I initially interpreted the visibility of encampments and homelessness in Tokyo as a sign that the broader public had greater understanding or empathy regarding homelessness relative to the United States, I now believe that this quasi-liberation of homeless life, similar to what I saw in Kuala Lumpur, may just be a sign of a policy system changing gears. In Tokyo in the late 1990s, public concern for homelessness had mushroomed as visible protest against evictions received positive media attention; this empathy triggered a gradual slowing down of public order enforcement, just like Kuala Lumpur's, for the purposes of minimizing controversy while agencies regrouped for the development of new policies.

Tokyo's relative freedom, therefore, was short-lived. Government enacted a new national policy on homelessness in 2002, which signaled its intent to more keenly govern the relationship of people experiencing homelessness to public spaces through a statute aimed to ensure "appropriate use" of public facilities. Soon after, in 2004, a new program 
offering low-cost housing was enacted to reduce encampments throughout Tokyo-and this inspired new policies ${ }^{2}$ and agencies governing public space. When I returned to Tokyo in 2017, I learned that public and civic sector agents, now obliged by various policies to conduct weekly outreach patrols, regularly approach people experiencing homelessness. Such intervention is not unjustified as it serves the purpose of informing people of public assistance options, such as entry into the self-reliance shelter system or applying for welfare aid.

At the same time, under current law, outreach is designed to double as a mode for informing people of the parameters of "appropriate use” and, depending on the manner and discretionary intent of the agent, urge the uptake of welfare options and/or relocation. I met several people who felt policed under the current policy regime-albeit by officers not affiliated with police but instead more "friendly" or dispassionate agencies like welfare or transportation. By this legal framework, welfare is increasingly framed as compulsory for all citizens. Hence, while this is not equivalent to, for example, the mass roundups and detention I witnessed in Kuala Lumpur between 2011 and 2014, the difference between the two is, in my view, only one of degree. Once I recognized a liberation of sorts taking place in Kuala Lumpur after the toning down of rescue operations, I also recognized in Tokyo a gradual loss of freedom by virtue of its enhanced public order measures.

\footnotetext{
${ }^{2}$ Tokyo metropolitan's last formal count in 2016 shows a reduction of over $90 \%$.
} 
Modern spatial and social development—and imperatives of order

At the end of the nineteenth century, public policy was largely comprised of public order systems that regulated people through spatial segregation—often through arrest and imprisonment—-to protect "good” members of society. Scholars such as Garland (1985) have underscored the largely punitive nature of past measures, but they were not exclusively so: interest in rehabilitating people also grew across the nineteenth century. Over this century, as new technologies facilitated the rapid expansion of colonial rule and information exchange, policy practitioners began experimenting in rehabilitative reform and associating it with "civilized” society, while distancing themselves from penal practices such as confinement and corporal punishment, increasingly characterized as barbaric. As David Garland (1985, 2001) details this history, he highlights two major policy shifts over time: first a welfarist turn inspired by the ethos of social development and investment in productive and reproductive labor and life in the early twentieth century, and a punitive turn towards neoliberal austerity and penalty in the late twentieth century.

In decades since Garland’s “punitive turn” thesis, additional scholarship (Cloke et al 2010; DeVerteuil et al 2009; Johnsen and Fitzpatrick 2010) has presented how this turn has been more nuanced. For instance, while heavy-handed evictions did recur in Tokyo in the 1990s and early 2000s, civic protest and public opposition led to the incorporation of new policies that have led to the more neutral, or even helpful, managerialism of “outreach” systems today. Policies that appear to carry exclusionary objectives are often infused with caring aims and compassionate rhetoric, which "blurs" (Hennigan and Speer 
2018) the actual directionality of policy. Stated differently, the punitive nature of the punitive turn has been arguably diluted—or perhaps the turn itself was not purely punitive.

While I do adopt compassionate, ambivalent, and punitive frames where they are useful in describing policy aims and effects, I have come to view the broader shift as one moving between preference for spatial or social objects of control. At present, I believe that what has been summarized as a trajectory of welfarist and punitive turns over the modern history of advanced capitalist nations may be better read as an alignment of policy: 1) from imperialist material and economic interest in expanding capitalist markets through spatial development across the latter-half of the nineteenth century, 2) to post/imperialist political-economic interest in gains accrued through social development (and control over divisions of labor) for much of the twentieth century, and 3) to today's neoliberal financial interest in land and the consolidation of power accrued through spatial development and control. Moreover, it appears to me that Global South countries like Malaysia have not necessarily followed the same course as the Global North. For instance, my research suggests that interest in social development in Malaysia has grown in recent decades—despite neoliberal austerity rhetoric —-with roots in labor shifts sparked under the New International Division of Labor.

Fundamentally, the compassionate, punitive, and even dispassionate managerial aims that punctuate each city's history of homelessness regulation are expressions of political strategies and instruments for asserting power. Plainly stated, they justify and serve global and local capitalist interest in spatial and social development (i.e. land and labor) and — by extension—spatial or social control. The ways in which spatial and social 
control are exercised over individuals - regardless of whether they are punitive, supportive, or dispassionate and managerial—has profound ramifications for social existence itself, as seen in both Kuala Lumpur and Tokyo today. These forms of regulation can and do impinge on people’s liberties and rights and, by extension, the very foundation of our democracies.

Global history, compassionate acts, and power

As noted above, understanding homelessness regulation today requires understanding regulation in the past. Homelessness has been seen—or framed—as a metonym for social and spatial disorder since the mid- to late-nineteenth century, when Euro-American imperialist agents became increasingly fixated on comparatively assessing each society's level of civilization by its spatial and social order. Policy tools since developed to manage perceived socio-spatial disorder necessarily express each era’s particular anxieties. For instance, prior to the welfarist turn in the late nineteenth and early twentieth centuries, policies addressing homelessness were used to spatially contain populations deemed dangerous on account of their supposed criminality, (biological) contamination, and/or political insurgency. This was also true in Tokyo and Kuala Lumpur, where the Meiji state and the British colonial administration, respectively, managed social and spatial order almost exclusively through police. At this time, state measures relied heavily on forced clearance and containment, including policies centered on providing care, including through Japan’s Sick Traveler's Law, the Tokyo Poorhouse, and Kuala Lumpur’s Pauper Hospital. However, anxieties and expressions of care shifted 
as political and economic players developed greater corporal interest in uprooted and impoverished people in each city.

As explained in the subsection above, homelessness regulation underwent a more compassionate, welfarist turn in the early twentieth century as resource extraction, industrial production, and transnational commerce quickened over capitalism's global expansion. The incorporation of care into policy, also expressed through the reduction (but not elimination) of segregation and clearance, had everything to do with the political and economic value of labor and loyalty among imperial and colonial subjects. In the mid- to late-nineteenth century, allocations for housing, food, and transport granted to imperial officers dispatched to colonial territories like Kuala Lumpur were standardized and served as a precursor to what later took shape in metropoles as social assistance for the "uplift" of the poor. For instance, in Kuala Lumpur, high-ranking British officers would receive houses with allowances for their wives and children, whereas middleranking officers—often unmarried—would receive more modest accommodation but with subsidized domestic help, and the lowest classes of workers would generally get shared quarters (not unlike today’s shelters) with migrant “coolies” receiving the worstoften located next to livestock or in tents. In this way, the quality and quantity of aid for public service was typically determined in line with nationality, race, gender, age, marital status, and class. Over time, government agencies became more conscious of the stability that material and economic provisions brought to laborers and, by extension, political and economic security for the colony and empire. These systems of public investment in labor-including its reproductive needs was then slowly adapted over time from colonies into the metropoles. 
At the same time, however, the British colonial administration was not willing to carry responsibility for the social well-being of society at large, comprised in Kuala Lumpur of European and Chinese entrepreneurs, British colonial public servants, and Indian and Chinese migrant laborers. Therefore, state actors chose to operate through nodes of power organized around racial, religious, geographic, linguistic, and genderbased categories that enabled them to entrust management of fractious publics to devolved networks of lower-level agents through legal pluralism (Benton 2002) and other systems. This divide-and-rule methodology, by definition, precluded any kind of universal or comprehensive programmatic approach ${ }^{3}$ to resolving problems as each nationality and class had to be managed separately. Thus, colonial governance necessarily produced piecemeal social policies (Midgley 2011) that structurally required individual subjects to seek aid for immediate problems through race-, class-, and genderspecific networks of social belonging. For instance, while British colonial administrators determined the general direction of policy for so-called vagrants-they left funding and implementation to separate institutions, each operating by different standards and rules for people of varying race, class and, gender-resulting in widely divergent outcomes for vagrants of different class backgrounds and nationalities, including European, American, Indian, Chinese, and Japanese women, men, and children.

In metropoles, public agencies managed minimal social infrastructure through the late nineteenth century, as they largely left matters of public welfare to private-sector

\footnotetext{
${ }^{3}$ For instance, decrepit camps only existed for Indian and Chinese persons and, once inside, their prospects for repatriation versus Malayan residence was largely left to the discretionary judgement of multiple agencies. Moreover, no formal policy existed for European vagrants and, as one would suspect, those from upper-class backgrounds were granted more liberty in determining their own outcomes.
} 
philanthropists. Japan’s civic agents—inspired by the Salvation Army and other European reformists seeking to uplift and enlighten the "savage” urban poor—opened free and low-cost shelters and employment referral centers in Tokyo's most impoverished districts. Before long, Japan’s public agencies began utilizing and working these private institutions into public systems. This switch hinged on the growing efficacy of these institutions and an ethos of benevolent state care in enforcing particular modes of social and spatial organization advantageous to industrial capitalist development. Social programs acted as a bond for keeping subjects "invested" in the status and economy of the empire, while care became the basis upon which state agents could exercise power over individual conduct.

Moreover, as social movements grew stronger over the early twentieth century, state-provided assistance and, gradually, the expansion of democratic suffrage proved to be valuable instruments for bringing marginalized groups—such as women, propertyless men, outcaste burakumin ${ }^{4}$, Chinese laborers, and Korean students—on board with the empire's agenda. That is, state and society were brought closer together within the boundaries of an imperialist and limited democratic system while social programs tied their security to the present and future of the polity. Hence, social and political rights and protections - necessarily distributed in line with raced, gendered, and classed norms facilitated specific modes of social organization—served as currencies for securing the economic labor and political loyalty of individuals in the imperial/colonial state.

\footnotetext{
${ }^{4}$ Burakumin are descendants of a feudal caste-based group associated with impure or tainted occupations, and thus deemed (according to the feudal caste system) to exist outside of human society.
} 
Under this early twentieth century shift, policies conveyed new anxieties, which emerged from desire to preserve and even elevate industrial economic growth (i.e. idleness), a civil social order (i.e. deviance) and collective status or prestige (i.e. disgrace) now that policy aims of integration rather than segregation ostensibly took precedence. People grappling with social and economic insecurity — whether they were extracting resources in colonies or underwriting industrial production in metropoles-were offered limited protection and compensation for their contribution to empire, but these were implicitly and explicitly calculated in line with raced, gendered, and classed systems of valuations. This often opaque and irregular distribution of resources and power meant that individuals were compelled to appeal to, or appease, only proximate nodes for survival. Under such a structure, elites gained political legitimacy not from the public per se, but from their relations with each other-in networks external to the public.

Consequently, these paternalistic systems of aid and compassion were necessarily entangled with views and valuations that ultimately upheld and affirmed, if not exacerbated, inequalities. Because government agencies calculated different standards of care for people based on race, gender, class, and ability, social policy systems were marked by inconsistencies in the quality of care delivered to communities, households, and individuals both inside each of the metropole and the colony, as well as between them.

After World War II, Japan and Malay(si)a were each occupied by Euro-American imperial powers that guided them to independent governance, lasting through 1952 and 1957, respectively. Over this span, groundwork for a new international order was also being laid. Within this order, headed largely by British and American experts, supportive 
welfare-state programs were deemed quintessential markers of advanced capitalist states. The welfare state formed in Japan ensured most citizens relative housing and income security through universal programs as well as specific aid disbursed to senior citizens, persons with disabilities, and persons grappling with unemployment or illness. These programs bolstered intergenerational security for normative households who, in turn, became Japan's middle class. However, because of the overall system's sociallyconservative orientation, that is, built-in mechanisms for offering people different standards of aid based on their nationality, gender, occupation, marital status, and so on, particular groups such as resident (zainichi) Koreans, single mothers, formerly incarcerated persons, casual laborers, and people experiencing homelessness were rendered more vulnerable to exclusion from protection and, by extension, financial and material insecurity.

Conversely, international experts argued that welfare-state systems were not suited to former colonies as they believed them to be insufficiently developed socially, economically, and politically. British experts in particular argued that, in an independent Malaya, programs of social restraint and austerity carried greater feasibility, particularly because they would preclude problems of public expense and mass dependency. Hence, in postwar Malay(si)a, social insurance systems were organized into two tiers-both of which preceded the postwar era. First there were credit and thrift societies, re-introduced in 1948 for poor households in fishing, agriculture, and other domestic industries. These organizations provided relative collective security, and tethered individuals to geographic communities and industries. Second, from 1951, labor and social insurance systems providing pension, health care, and other benefits and transfers brought intergenerational 
economic security to households with enough social, political, or economic capital to enter middle- and upper-class jobs. Consequently, homelessness primarily affected people thrust into gaps between these systems, like those who lost ties to community and family or access to social insurance. Most often, however, this meant foreign-born or rural-urban migrants who were injured, ageing, or displaced from rapidly modernizing industries, as well as women, men, and children seeking an exit from community and/or family.

My main fieldwork sites in Tokyo and Kuala Lumpur — that is, Sanya in Tokyo as well as the area between Central Market and Chow Kit in Kuala Lumpur, each known as slums throughout their histories — originally formed in the late nineteenth century as spaces for displaced persons and migrant laborers to find employment and accommodation. In the early twentieth century, as private- and public-sector agencies began investing in infrastructure in these spaces, they developed into enclaves (Tokyo’s yoseba and Kuala Lumpur's Chinatown today) for marginalized laborers and, from the perspective of government, served as a fixed point for organizing and managing labor power.

These districts were not only disproportionately populated by people from marginalized backgrounds—such as the burakumin, Korean, and Ryukyuan individuals in Tokyo and Chinese and Javanese migrants in Kuala Lumpur- - but also located next to neighborhoods that historically served as sites for the spatial containment of other marked communities. Hence, there has been layer on layer of stigma associated with these zones and their residents for over a century, including associations with crime, vice, and 
poverty. The need for labor throughout wartime, interwar, and postwar eras guaranteed the maintenance of these spaces for their productive and reproductive purposesespecially because the geographic area itself was so well-linked into global capitalist systems by virtue of its proximity to railway and waterway transportation hubs and infrastructures.

From the late 1960s and 1970s, in Japan, yoseba spaces began to manifest more visible suffering and death as the middle- and upper-classes increasingly distanced themselves from city centers and urban life. At the same time, anxieties linking yoseba neighborhoods and homeless people to filth, violence, and depravity bolstered policy action designed to protect the public from physical proximity by ramping up policing in the so-called slums of Sanya, and practices of taraimawashi (moving people along) outside Sanya to ensure their containment within the yoseba. Public works programs and emergency winter shelters were sustained, but other than these, imperatives of social care appeared to ease with enhanced spatial management.

In Kuala Lumpur, however, care appears to have been somewhat ascendant. In 1965, the Parliament passed the Vagrants Act, which created an avenue for police to take people into custody, not for the crimes of homelessness or begging but rather compulsory (and indefinite) rehabilitation for the same provided in remotely located institutions run by the welfare ministry. At this time, spatial interest in the city center due to increased tourism and international events in the 1960s lead to increased action and calls for more compassionate policy. Hence, in 1977, the Vagrants Act was revised to replace police with welfare officers at the frontlines conducting "rescues" and renamed to the Destitute Persons Act. Thus, in Kuala Lumpur, Malaysia’s most densely-populated labor market 
area during the Global North's internationalization of industrial production—primarily to Southeast Asia — the positive pursuit of social and spatial development went hand in hand.

\section{Homelessness Today and Related Policy Regimes}

Japan's prewar trajectory as a rapidly industrializing capitalist economy—guided by clear programmatic agendas for social and spatial governance—-served as the foundation for its postwar multi-level regulatory frameworks that established and continued to guide formal land and labor markets over much of the twentieth century. By this system, homelessness in Tokyo's 23 wards is governed by over 50 agencies at multiple levels ${ }^{5}$, or approximately 20 agencies for each ward, spanning four levels of government in line with roughly as many laws, policies, programs, and by-laws (Table 2, left - example of Taito Ward).

In Kuala Lumpur, where post/colonial governance has been highly centralized, autocratic, and responsive to external political-economic interests over domestic democratically-determined ones, both the state and the public have relied on informal markets to temper material insecurity—symptomatic of a lack of social policy. In the eyes of the state, informal markets have served two purposes: 1) to ensure domestic labor and land markets can flexibly respond to external demands and 2) to ensure social burdens such as welfare, health care, and housing are largely managed through sociallyconservative—or so-called traditional—institutions such as "self-help", community and

\footnotetext{
${ }^{5}$ Such as, with regard to welfare, the Ministry of Health, Labour, and Welfare; the Tokyo Metropolitan Government Bureau of Welfare and Insurance, the Special Ward Human Resources and Welfare Bureau, and a ward-level Livelihood Assistance Office.
} 
family. Consequently, homelessness in Kuala Lumpur is governed by just three laws

under ten agencies, all federal (Table 2, right).

\begin{tabular}{|c|c|c|}
\hline & Tokyo (Taito Ward) & Kuala Lumpur \\
\hline $\begin{array}{l}\text { Agencies } \\
\text { involved in } \\
\text { development } \\
\text { and } \\
\text { enforcement } \\
\text { of } \\
\text { homelessness- } \\
\text { specific } \\
\text { policies, as } \\
\text { verified } \\
\text { through } \\
\text { interviews } \\
\text { (Legislative } \\
\text { not included) }\end{array}$ & $\begin{array}{l}\text { Central } \\
\text { - } \quad \text { Ministry of Health, Labor, and Welfare } \\
\text { - } \quad \text { Kanto Regional Development Bureau at } \\
\text { the Ministry of Land, Infrastructure, and } \\
\text { Transportation } \\
\text { - } \quad \text { National Police Agency } \\
\text { - } \quad \text { Parks Association (Quasi-Government) } \\
\text { - Japan Sports Council (Quasi-Government) } \\
\text { Metropolitan } \\
\text { - } \quad \text { Fire Department } \\
\text { - } \quad \text { Welfare and Insurance Bureau } \\
\text { - } \quad \text { Industrial Labor Bureau } \\
\text { - } \quad \text { Consan Development Bureau } \\
\text { - Metropolitan Pureau } \\
\quad \text { local station and sub-stations, e.g. Asakusa } \\
\text { Station, Nihontsudumi Police Box) } \\
\text { Special Ward } \\
\text { - Special Ward Human Resources and } \\
\quad \text { Welfare Bureau } \\
\text { Ward/City } \\
\text { - Parks Office } \\
\text { - } \quad \text { Livelihood Assistance Office }\end{array}$ & $\begin{array}{ll}\text { Federal } \\
\text { - } \quad \text { Ministry of Women, Family, and } \\
\text { - } \quad \text { Federal Territories Department } \\
\text { - } \quad \text { Ministry of Health } \\
\text { - } \quad \text { National Police } \\
\text { - } \quad \text { National Anti-Drugs Agency at the } \\
\text { - } \quad \text { Mome Affairs Ministry } \\
\quad \text { (RELA) at the Home Affairs Ministry } \\
\text { - } \quad \text { National Welfare Foundation (Quasi- } \\
\quad \text { Government) } \\
\text { - } \quad \text { Alam Flora (Government-linked) } \\
\text { Federal Territories (Kuala Lumpur) } \\
\text { - Social Welfare Department Kuala } \\
\quad \text { Lumpur } \\
\text { - } \quad \text { Kuala Lumpur City Hall } \\
\text { - } \quad \text { Federal Territory Islamic Religious } \\
\quad \text { Council (MAIWP) }\end{array}$ \\
\hline Laws/Policies & $\begin{array}{l}\text { (Enforcement governed by Administrative } \\
\text { Procedures Act) } \\
\text { Central } \\
\text { - National Constitution } \\
\text { - } \quad \text { Act concerning Special Measures to Assist } \\
\text { Self-Support among the Homeless Act } \\
\text { - } \quad \text { Urban Parks Law } \\
\text { - } \quad \text { Roads Act } \\
\text { - Livelihood Assistance Act } \\
\text { - Minor Offenses Act } \\
\text { - Administrative Subrogation Act } \\
\text { (Evictions) } \\
\text { Metropolitan } \\
\text { - Tokyo Metropolitan Park Ordinance } \\
\text { - Tokyo Metropolitan Park Ordinance } \\
\text { Enforcement Regulations } \\
\text { - Tokyo Metropolitan Implementation Plan } \\
\text { for Special Measures to Assist Self- } \\
\text { Support among the Homeless } \\
\text { - Sanya Measures } \\
\text { Metropolitan Roadside Environmental } \\
\text { Cleanup Measures } \\
\text { Special Ward } \\
\text { Special Ward Measures for Street Sleepers } \\
\text { - Pilot Program } \\
\text { Tupportive Transition-to-Community-Life } \\
\text { Trogram (from 2020) } \\
\text { - Ward Parks By-laws } \\
\text { - Children's Recreation \& Sports Parks By- } \\
\text { laws }\end{array}$ & $\begin{array}{l}\text { (Limited by Government Proceedings Act) } \\
\text { Federal } \\
\text { - } \quad \text { Federal Constitution } \\
\text { - } \quad \text { Destitute Persons Act } \\
\text { - } \quad \text { Penal Code } \\
\text { Child Act }\end{array}$ \\
\hline
\end{tabular}

Table 2. Government agencies and laws used to govern street homelessness. 
Tokyo’s neoliberal policy regime

Homelessness surged in the 1980s and 1990s. At the time, it was perceived and reported as being “new” because of how it increasingly affected blue- and white-collar regular workers throughout Tokyo, rather than just the yoseba and its casual laborers as before, due to mass retrenchment during recessionary corporate restructuring. Although universal welfare is guaranteed to all via Article 25 of Japan's constitution, men—and particularly those without families — were often deemed fit to work by street-level bureaucrats and turned away at welfare offices for decades. In addition, many people also opted to avoid the stigma of welfare by not applying for aid. Ultimately, over the 1990s, homelessness increased tenfold in Tokyo alone.

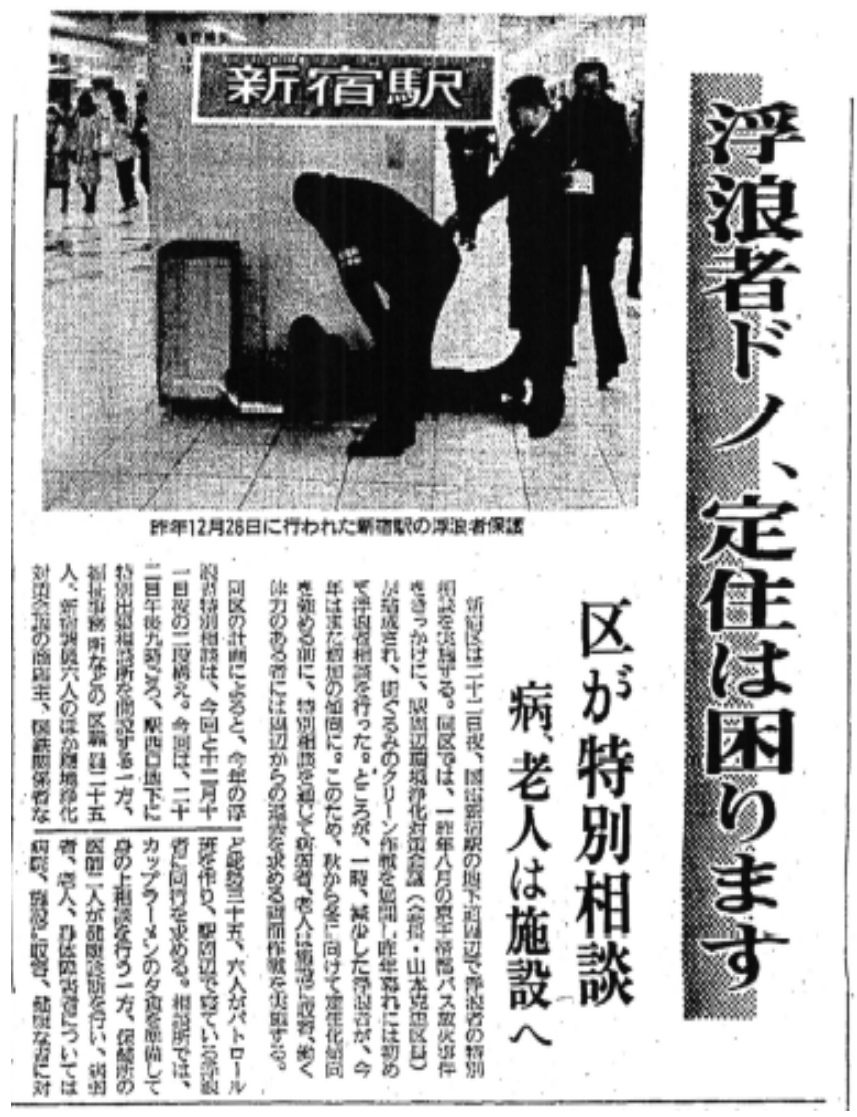

Figure 1. Article on homelessness: Mr Vagrant, Sir, you can't stay here Source: Yomiuri Shimbun, Sept 14, 1982 
In the mid- to late-1990s, the Tokyo Metropolitan government devoted itself to the cause of urban renewal (toshi saisei) as a solution to Tokyo's economic slump, often attributed in part to its declining international status (Shima et al 2007; Waley 2007). Early projects revolved around the development of urban underground thoroughfares, often for commercial and recreational use in proximity to subway stations, where swelling numbers of people experiencing homelessness already tended to congregate, particularly during winter and summer months (see Figure 1). In response, local governments extended patrols to clear underground spaces, but this, in turn, lead to a rise in the number of settlements outdoors. As a result, ward and metropolitan governments sought other solutions (Hasegawa 2005; Shima 1999; Tokubetsu-ku Kyōgikai 2017). In 2002, Japan's Diet passed the Self-Reliance Support Act formally recognizing the central government's responsibility to address homelessness by bolstering self-support (Article 1) and the authority of public agencies "to ensure appropriate use” of waterways, roads, and parks (Article 11).

As metropolitan self-reliance shelters were inaugurated under the 2002 Act, state agencies noted that people living in tents-approximately 60\% of Tokyo’s homeless population (Shinjuku Ward 2006)—were the least likely to enter temporary shelters and work search programs because many had secure accommodation and an income stream (Ministry of Health, Labour, and Welfare 2003; Shinjuku Ward 2006). The metropolitan government, however, was determined to address "the lack of reduction in numbers of tents, representing approximately 2400 persons $^{6 "}$ (Housing First Kenkyūkai 2013:16;

\footnotetext{
${ }^{6}$ In Japanese, "heranai burū tento = koremade no torikumi ni kuwaete aratana torikumi ga hitsuyō na sō, yaku 2400 nin."
} 
also TMG Construction Bureau 2004:30), which it did by launching its Transition-toCommunity-Life Program in 2004 targeting tents near commercial districts like Shinjuku, Shibuya, Taito and Sumida (Figure 2). The Program began in Shinjuku, Tokyo's administrative district, and brought an over 50\% drop in numbers of tents between 2003$2004^{7}$. Two-thirds (420 people) of people relocated received a two-year contract for subsidized housing under the Program (Kubota 2009). People who refused metropolitan aid were allowed to remain in parks, while government agencies introduced new security measures to make any future re/settlement of abandoned park space impossible.

Number of homeless persons in Tokyo's 23 wards according to an August 2005 survey

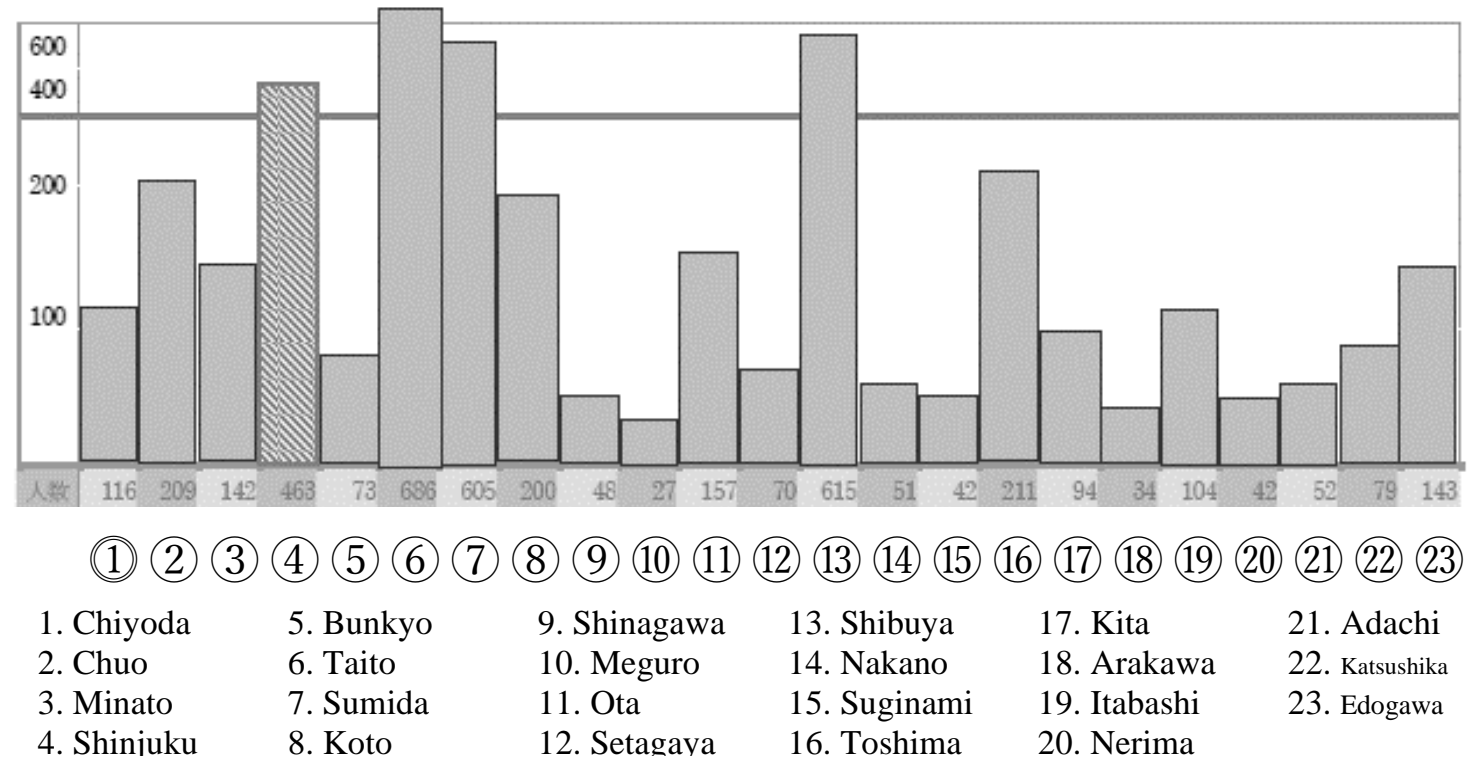

Figure 2. Results of 2005 survey showing highest concentrations of homelessness. Source: Shinjuku Ward (2006:11) (Translated by author)

Over this same span, ward governments also adopted more expedient means of clearing open spaces. Following September 11, 2001, government agencies began restricting public access to parks and facilities, underscoring security concerns, and often

\footnotetext{
${ }^{7}$ From 1102 to 463 tents according to Shinjuku Ward (2006:6).
} 
installing enclosures, locks, and cameras after evicting encampments (Haraguchi 2016; Hayashi 2015; Murota 2017; Sasanuma 2008). Similarly, after the 2011 Tohoku Earthquake, Shibuya and other ward offices began closing public spaces ostensibly for earthquake-proofing and structural upgrades, thus justifying additional evictions (Shimokawa 2013). In 2013, once Tokyo won its bid for the 2020 Olympics, pressure to commodify and improve Tokyo's image has reached a fevered pitch. As part of this, Japan's central government and the International Olympics Committee have become embroiled in a lawsuit after the former pushed through an unlawful eviction of just under 10 people from Meiji Park in January 2016. Government surveys indicate that street homelessness in Tokyo is at an all-time low, a data point often credited to welfare measures ${ }^{8}$. Yet, security measures have also comprised a sizeable portion of work undertaken, with their own unique effects. In Taito Ward, for example, ward level officers from the Park and Welfare Offices conduct 156 and 48 patrols, respectively, each year with authority to engage people experiencing homelessness ${ }^{9}$.

Kuala Lumpur, Malaysia

The 1980s and 1990s were decades of profound transformation. Prime Minister Mahathir took charge of the capital as part of his plans to transform Malaysia into a firstworld economy while also pushing neoliberal change including deregulation, financial liberalization, public spending cuts, and "mega-projects" to attract global finance. As

\footnotetext{
${ }^{8}$ Such data excludes, however, rising numbers of "internet café refugees" or unsheltered persons sleeping in business establishments like restaurants, saunas, and internet cafes.

${ }^{9}$ Email correspondence with Officer Kurita of the Parks Office at the Taito Ward Urban Renewal Bureau (Taitō-ku Toshi-Dzukuri-bu Kōen-ka) October 18, 2018
} 
manufacturing and service industries expanded rapidly, demand for labor grew in the capital, which drove in-migration from East and West Malaysia and beyond. Government agencies managed pressure on the capital by more stringently regulating urban poor communities including so-called vagrants and beggars who, according to the welfare minister, "mak[e] a nuisance of themselves [so we must] round them up and put them in rehabilitation centres” (Minister orders checks 1996). To maximize efficiency, the Kuala Lumpur Social Welfare Department began incorporating officers from the National AntiDrug Agency, the Immigration Bureau, and police forces into its anti-vagrancy operations (see Figure 3), thereby forming multi-agency enforcement teams.

Concurrently, as Malaysia's middle class grew, so did the number of CSOs and their willingness to challenge state policies. One early critic noted, "authorities say the operations will continue until the city is free of its homeless people... [but a] true solution requires a far greater social undertaking.” (Ramlan 1993)
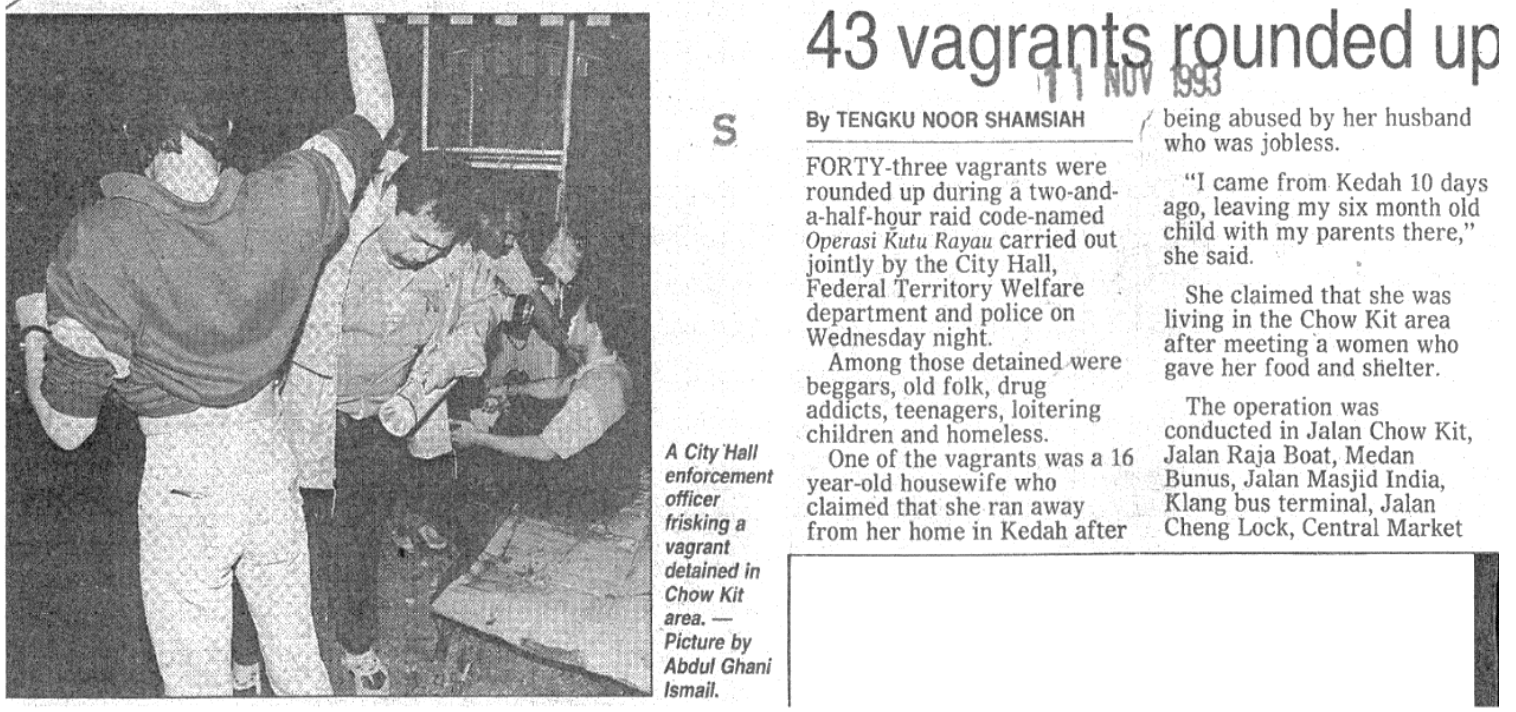

Figure 3. Newspaper article on Operasi Kutu Rayau, or vagrant operations. Source: The Star, November 11, 1993. 
In 2010, Prime Minister Najib announced the launch of one such social undertaking using federal funds: a pilot transitional "home for the homeless", according to government and press materials. Once established, this shelter—named Anjung Singgah — was entrusted by the federal government to the National Welfare Foundation, a quasi-governmental organization chaired by the Minister of Women. While federal funding continued through 2013, covering the launch of six new Anjung Singgah facilities nationally, it formally remained a one-off allocation renewed only intermittently in years since. However, state-orchestrated fanfare surrounding Anjung Singgah starkly contrasts the discreet federal expansion of DPA detention infrastructure under the Ministry of Women, Family, and Community Development. Between 2010 and 2014, the Ministry opened two new rehabilitation centers and instituted statutory and organizational reforms bringing DPA enforcement to more closely resemble law-and-order models (i.e. policing with powers of arrest). When federal agencies announced new stringent regulations in 2014, protest from CSOs forced them to backtrack ${ }^{10}$ and, instead, develop plans for two new transitional shelters—opened in 2016 and 2017—-that include “integrated” CSOs offering meals, clothing, medical care and other aid on-site. While Anjung Singgah is still administered under the National Welfare Foundation, KL's two new facilities have been handed over to Kuala Lumpur City Hall, the new face of homelessness management. City Hall also patrols the River of Life district and other tourist areas to ensure that, in their words homelessness does not remain

\footnotetext{
${ }^{10}$ Although clearance measures were indeed implemented, albeit at a smaller scale than initially planned.
} 
"unchecked... with regards to the image of the capital city"11. Notably, DPA operations have doubled nationally between $2013-2017^{12}$. These include, since 2016, new antibegging campaigns and anti-begging operations that structurally replicate multi-agency operations used to tackle homelessness since the 1980s. As in Tokyo, state duties vis-avis welfare are being increasingly delegated to CSOs, private sector actors, and locallevel authorities, while non-welfare agents take up less touted positions as foot soldiers directly engaging people as part of public order interventions.

In light of these and other changes over the last several decades in each of Tokyo and Kuala Lumpur, I answer the following questions:

- How have these changes impacted people experiencing homelessness?

- What do they say about the past and present formation of homelessness policy?

Narrative Outline of the Dissertation

This dissertation explores the institutional framework and street-level impacts of homelessness regulation in Tokyo and Kuala Lumpur from the mid-nineteenth century to the present, while considering how global historical political-economic shifts have shaped contemporary policies in each context. In Chapter 1, I provide an outline of literature on governance and policies related to social and spatial control as well as homelessness across the modern era. I also provide an overview of my methodology for

${ }^{11}$ Email correspondence with the Policy Planning Division at the Ministry of Federal Territories' Town Planning Section, June 3, 2019.

${ }^{12}$ Moreover, numbers nearly sextupled in KL in 2017 from 348 to 2310 persons (Jabatan Kebajikan Masyarakat 2018:132, 2017:136) 
dissertation research. Chapters 2 and 3 detail the locally-situated ways in which homelessness has been (re)constructed as a problem of social and spatial disorder across modern history, ostensibly threatening spiritual and material modernity, defined differently across Kuala Lumpur’s post/colonial (Chapter 2) and Tokyo’s post/imperial (Chapter 3) context. This policy construction upholds what I identify in Chapter 3 as the legacy of vagrancy law: a delegitimization of homelessness across multiple policy fields, rendering it grounds for criminalization, eviction, public assistance disqualification, and political disenfranchisement. Chapters 4 and 5 are ethnographic chapters offering insight into how this and other imperial legacies shape contemporary policy governing street homelessness (Chapter 4) and related institutions of labor, welfare, and care (Chapter 5). Specific material explored in each chapter is as follows.

In Chapter 1, I introduce in a literature review how particular modes of social and spatial organization have been bound up in policy ideas and institutions over the course of modern capitalist expansion as mechanisms for preserving the relative privilege of particular people. In Chapter 2, I review from a global historical perspective the regulation of homelessness in modern Kuala Lumpur (1970s-2018). Therein, I identify commonalities and differences between Malay(si)an paradigms of regulation and those commonly attributed to Global North contexts. In Chapter 3, I similarly review the regulation of homelessness in modern Tokyo (1868-2019) while also identifying the form and effect of imperial formations, or uneven relations of power, in homelessness-related policy across its history. In Chapter 4, I explore the role of compassionate actors, that is, the interest of public- and private-sector organizations in the neoliberal-era adoption of compassionate rhetoric and supportive policies surrounding the socio-spatial governance 
of street homelessness in both cities. Here, in addition to highlighting each city's changing policy landscapes, I also explore enhanced CSO participation in policy processes and its implications for democracy. In Chapter 5, I explore the social and geographic im/mobilities experienced by people who enter institutions of welfare, labor, and care and the relation of these $\mathrm{im} / \mathrm{mobilities}$ to the political and economic interests of middle- and upper-class organizations and interests. Last, in my concluding chapter, I explore the significance of these findings to underscore that a democratic, humane solution would require full legalization and public recognition of homelessness as not an aberration but an unexceptional variation in modern distributions of wealth and power.

Value of Research - Legacies and Democracy

By illuminating how past trajectories of homelessness regulation have shaped contemporary regimes and their street-level impacts using the cases of Tokyo and Kuala Lumpur, this dissertation offers insight into policy ideas, institutions, and processes of diffusion that are of critical importance for understanding contemporary regulation globally—particularly in light of shared global histories and related policy networks. More specifically, I identify legacies of imperial and colonial politico-legal cultures in contemporary policy configurations and processes that not only reproduce structural inequalities but also systematically undermine democracy. 


\section{CHAPTER 1. LITERATURE REVIEW AND METHODOLOGY}

Social and Spatial Order in Global History

Homelessness has long been a matter of distinct state concern. At the foundation of homelessness regulation historically and today is anti-vagrancy law, or legal statutes that emerged in mid-fourteenth century Europe to control the movement of people uprooted by expanding systems of private property. This "bloody legislation against vagabondage” (Marx and Engels 1996:732) did not assume a position of major importance ${ }^{13}$ until traditional European economies transitioned into wholly capitalist ones at the turn of the sixteenth century. This shift began with England's Enclosure Movement, or the consolidation of open fields into private holdings, which occurred alongside a new boom in industry and the proliferation of roadways facilitating migration and commercial exchange (Beier 1986; Kiddey 2017). Because modern capitalist systems have necessarily triggered profound social and spatial effects through expropriation—or, land seizure and mass dispossession—vagrancy regulation historically served as a crucial instrument for protecting capitalist territories against threats posed by “idle” and "wandering” persons. The enforcement of vagrancy regulation—intended to suppress social and spatial disorder—continued as industrial capitalist systems were extended throughout Europe and much of the world over the next five centuries of colonial and imperial expansion and governance.

\footnotetext{
${ }^{13}$ For more on debates regarding the role of the Enclosure in the formation of modern capitalist systems, see Lazonick, W (1974) Karl Marx and Enclosures in England. Review of Radical Political Economics 6(2):1-59.
} 
History is not linear and, similarly, the effects of multiple centuries of capitalist globalization have been neither singular nor homogenous. Although globalization is often characterized as a "homogenizing” or "flattening" (Friedman 2005) force—one presumed to have at its endpoint the ubiquity of Western capitalist modernity (Krishnaswamy 2008) — its course has been far more complicated, and outcomes tend to produce divergences, conflicts, and contradictions as often as they unify. In the following chapters, I look at modern homelessness regulation in Tokyo, Japan and Kuala Lumpur, Malaysia, from the integration of each city into the world economic system in the midnineteenth century to the present. While vagrancy laws mark the early decades of capitalist transformation —and remain in force to this day—-their role and effects have changed, as have related ideas and institutions still bound into the fabric of our political, economic, and social lives (Garland 1985; Lowe 2015; Stoler 2008). Although I discuss laws, organizations, and practices that may technically exist in both cities, or one city across time, (including vagrancy laws, welfare departments, and outreach patrols) there should be no presumption that any single instance is substantively or effectually the same as another. Across time and space, the ideas and institutions underlying policy infrastructure carry within them multiple legacies of the global and local past as well as reflections of demands imposed by the present (Bhabha 1984; Comaroff and Comaroff 2006; Go 2008; Halperin 2015; Stoler 2006, 2008).

For much of its global history, homelessness regulation has been designed primarily to remedy "what officials saw as the disintegration of social order at the hands of urban life and capitalism” (Burton and Ocobock 2008:271). In this dissertation, I aim to trace varied forms of regulation across generations of political economic change in- 
and beyond — each city from the mid-nineteenth century to the present (2019). As I do so, I explore policy ideas and institutions that have served as mechanisms for preserving social and spatial order and, by extension, the relative privilege of elite groups by: a) politically and economically limiting the powers of people experiencing homelessness to ensure, b) conformity to continually-shifting-yet-rigid social divisions of labor and welfare, as well as conformity to the spatial organization of dominant modes of capitalist growth.

The Role of Social Science

A sociological study of global history must begin with recognizing how sociology itself has emerged from, and been complicit in, the same systems and networks that propagated imperial rule globally. Social sciences as we understand them today ${ }^{14}$ took shape over the course of nineteenth century imperialist projects driven by the "great powers" of Europe and the United States. The political and economic ambitions of these empires produced demand for knowledge of social, cultural, and geographic difference as captured in studies of language, religion, social and economic organization, and natural environment (Connell 2007). Similarly, principles of objectivity, self-discipline, and epistemic virtue — each heralded by the mid-nineteenth century as essential for true scientific inquiry—necessarily ensured that science itself could only be conducted by the so-called "civilized" or "modern” people who were not objects of study and sustained

\footnotetext{
${ }^{14}$ This is not to say that all of science itself is inherently Eurocentric. Sciences developed from other paradigms have, of course, co-existed and traveled continents for centuries. As Bhambra (2010) explains, scholarship that became the foundation of modern Eurocentric science merely produced the narratives and other structures of knowledge that produced and shaped the Eurocentrism itself.
} 
distance from objects of study; as such, they were wholly invested in the superiority and centrality of Western civilization (Blaut 1970; Daston and Galison 2007). For this reason, scientific methods, theories, practice, and other fundamentals of "objective" knowledge have, in fact, been built from Eurocentric biases (Bhambra 2010; Steinmetz 2013) intended to justify particular modes of social, political, and economic domination through the proliferation of normative ideas and institutions (e.g. Connell 1997; Magubane 2005).

At the turn of the twentieth century, sociology was inextricably intertwined with the "social turn" of imperialism, by which colonial agencies began advancing social research ${ }^{15}$ to "uplift” colonial populations through social "development” (Aspengren 2013; Duffield and Hewitt 2013). In the post-war era, this was replaced with the idea of modernization, which fundamentally held that societies could be guided along a linear trajectory from an impoverished and weak "traditional" state to a free and affluent "modern" state, based on evolutionist notions of social progress that upheld capitalist industrial societies as an ideal. As modernization theory developed throughout the 1950s and 1960s, its proponents generally took a "positive view of the imperial legacy" (Midgley 2011:2) as it was presumed to have provided former colonies with advantageous legal, educational, and administrative infrastructure for rational governance and economic growth. Modernization theory quickly proved influential because it was essentially an extension of the sociology that had already long-served as a "methodology and an ideational framework for action-oriented policy” in colonial development globally

\footnotetext{
${ }^{15}$ Only in particular colonies, rather than uniformly.
} 
(Aspengren 2013:47; Duffield and Hewitt 2013). Thus, discourse of "uplift” and social reform became in the post-war era "the discourse of development” (Escobar 1995).

In recent decades, postcolonial studies have transformed social sciences and humanities by calling attention to Eurocentricism and related normative bias in foundational ideas, institutions, practices, and norms while offering critical approaches to identifying these in enduring systems of Western dominance. Said's Orientalism offered a ground-breaking introduction to the ways in which Eurocentricism pervades popular and scientific knowledge and creates Orientalist ideas that enable people in positions of power "to manage — and even produce — the Orient politically, sociologically, militarily, ideologically, scientifically, and imaginatively” (Kapoor 2008; Said 1977:12). Similarly, Mbembe (2001) underscores that embedded cultural biases such as these, entangled in political and economic ideas and institutions, have facilitated the propagation of uneven relations of power after decolonization.

Postcolonial theory underscores how culture and society, including structures and relations, are dialectically shaped from the "ground up" through cooperation, opposition, negotiation, and subversion amongst actors. Bhabha (1984) identifies binary oppositions inflecting modern global culture—such as ideas of East and West, lazy and productive, objective and subjective, or deviant and proper-as uniquely fertile. Such binaries, he explains, serve to organize colonizing and colonized actors into discrete categories of difference while also discounting any convergence or overlap while, at the same time, dialectical interactions between parties necessarily produce new hybrids. Social science as it stands today still tends to distill objects, knowledge, and events into binaristic categories and, to the extent that we perpetuate this tradition, we become complicit in 
cloaking structures that justify inequalities by affirming the strength and glory of modernity (e.g. law and order), affirming the weakness of what opposes it (e.g. anarchy), and erasing the colonial wounds (e.g. genocide) (Mignolo and Tlostanova 2008). However, by “decentering” normative narratives and practices that underpin traditional science, we may make space for plurality—and better scholarship (Chakrabarty 2000). Scholars working in feminist, critical race, queer, (dis)ability and intersectional theory also share similar aims of decentering dominant discourses to better recognize and incorporate plurality. Such scholarship complicates and debunks notions of the universal subject (i.e. "the worker”) and universal experience (e.g. marriage, or poverty), among other things, by highlighting how social, political, and economic processes are shaped by the socially-constructed roles assigned to individuals and, by extension, their access to resources and power. Willse (2015:170) gets at the heart of such analysis as he states that, “It is not true that 'anyone’ could be homeless. Far from it”. Rather, he notes that colonialism and related traditions of biased thought and practice in American society have produced an implicit social truth of the disposability of particular "surplus" populations. Willse (2015:30) notes that to take accurate account of such processes, we do not need to "add...back in" processes of racism and exclusion to our investigations because "they are there already, submerged under universalist accounts...we [must] draw them back forward."

In this dissertation, I aim to make explicit the raced, gendered, classed, and otherwise biased forces of exclusion and their effects so as to include, rather than passively discount or omit, variation in individual experience with homelessness and related policy. Hence, in the following chapters, I aim to elaborate experiences, 
processes, and phenomena typically subject to exclusion based on their non-normative “difference”, including by methodologically embracing plurality. For example, this can be seen in my choice to conduct a global historical analysis of two cities of differential developmental status_-taking each as "ordinary cities” (J Robinson 2011)—as well as in exploring the relevance of diverse personal backgrounds, circumstances, and experiences, without seeking representative cases or generalizeable findings.

The Neoliberal Present

Sociological and geographical literature on neoliberal-era homelessness regulation tends to focus on the mechanisms and impacts of punitive and supportive tendencies in policy—often organized into binaristic categories. This would include the expansion of public space laws and security measures in recent decades, as epitomized by Smith’s (1996) "revanchist city”, or the promise of more compassionate responses in social policy, exemplified by the popularization of Housing First models and more vocal movements for rights. This focus is rooted in what Garland $(1985,2001)$ has termed a "punitive turn" in governance in advanced capitalist countries like the US, characterized as a retreat from universalist liberal principles and welfare-state systems towards "penal treatment of urban marginality” (Wacquant 2009:21). While critical scholarship on homelessness regulation has primarily adopted the punitive thesis (e.g. Amster 2003; Haraguchi 2016; Mitchell 2001), growing scholarship has directed interest in the interplay between punitive, supportive, and ambivalent strains (DeVerteuil 2006, 2012; Laurenson and Collins 2007; Marr 2015; Murphy 2009), also recognized by Garland 
(1985) in his conception of punitive welfarism. DeVerteuil, Mays, and von Mahs (2009) use the framework of "poverty management" (Wolch and DeVerteuil 2001) as a vessel to capture these various approaches in policy, and argue that a highly nuanced homeless regime birthed at the turn of the twenty-first century has rendered homeless spaces more complex. Few studies, however, have mapped complexities across time.

Complexity as expressed through punitive, supportive, and ambivalent tendencies in policy is visible alongside a global wave of re-urbanization that, as raised in Smith's (1996) work on revanchism, displaces working class and poor residents. Smith (2002:446) indicates that contemporary gentrification, unlike that of Glass’s (1964) era, has become generalized as a new global urban strategy "ambitiously and scrupulously planned” and enacted through the collaborative efforts of private and public actors who have produced a dangerous neoliberal urbanism that "mobilizes individual property claims via a market lubricated by state donations.” Recent literature on Japan draws attention to similar gentrification processes that incentivize exclusion of homeless persons from public spaces and the reconstruction of yoseba neighborhoods (Haraguchi 2016). In Malaysia, too, state involvement in urbanization processes and exclusionary pressures targeting urban poor communities—especially in Kuala Lumpur-have been the subject of sustained scholarly interest since the 1990s (Bunnell 1999, 2002; Bunnell and Nah 2004; Lepawsky and Jubilado 2014; Sabri and Yukuup 2008). In order to better understand relationship of homelessness regulation to urban re/development in each of Tokyo and Kuala Lumpur, I review the formation of current policy using archival and ethnographic data and a global historical view of policy mobilities (Kennedy 2016; McCann 2011; Peck 2003, 2011). 
Although neoliberal restructuring does play a large role in molding contemporary events, attention to its effects should not diminish our ability to recognize the legacies, or vestiges, of the past. Sparks (2012:1512) and Gowan (2010) offer rich illustration of how historically entrenched ideas of "homeless deviance and dependence work alongside and through" neoliberal policies in a "mutually constitutive" relationship. Such works show that contemporary state forms and governance are far from "historically unprecedented" (Halperin 2015: 69) but, instead, extend from past structures, practices, and ideas. However, the focus of leading scholarship tends to center on affluent, global North cities (Davis 2005) without considering relations to "'other' cities in 'other' places” (Oncu and Weyland 1997) or "ordinary cities" traversing the same networks (J Robinson 2006). This spatial and temporal myopia is indicative of imperial legacies that uphold and reinforce Euro-Americentric systems of knowledge, social practice, and cultural representation as paragons of truth and conventionality (Blaut 1970).

Additionally, considering the role of empire, and especially recent forms of EuroAmerican imperialism, in connecting much of the globe historically, greater attention is due to these "complex, multiple, and multi-directional cross-border colonial processes, circuits and formations" (Patil 2017:143) and their non-neutral lasting effects (Bhambra 2010) across multiple regions and scales. Therefore, I apply postcolonial theory to social science methods in an effort to decolonize Eurocentric paradigms by resisting traditional classification processes and "globalize” social (Go 2016) and spatial (J Robinson 2011) inquiry. As described above, this involves thinking across different experiences and allowing for pluralities (J Robinson 2011), rather than adopting essentialist, hierarchical constructs. Therefore, as I look at the global historical course of homelessness regulation 
in and across both cities, I also aim to make visible the webbed connectivities (Patil 2017) shaping regulatory regimes across time and space. I argue that ways of thinking about homelessness in policy and society—including the use of care and control— emerge from and are essential to imperial formations (Stoler 2008), defined as asymmetrical relations of power that, in homelessness regulation, propagate antidemocratic governance of people and places deemed disorderly.

Methods

In Colonialism in Question, Frederick Cooper (2005:4) raises the ethical dilemma of: "How can one study colonial societies, keeping in mind—but not being paralyzed by - the fact that the tools of analysis we use emerged from the history we are trying to examine”. I introduce this dilemma here because it also pervades research on homelessness—and particularly that relating to government intervention—because, by the turn of the twentieth century, knowledge and practices that emerged from governance of colonial territories was being applied to the management of poverty by public and private sector welfare agents in metropoles. For instance, as William Booth explained in the case of London, the poor were the "savages" of the "urban jungle" (McLaughlin 2000). This is to say that policies historically designed to address homelessness—and particularly those seeking to uplift and enlighten people through social work—emerged as technologies for managing populations perceived much like colonies were: incapable of self-governance.

Mignolo and Tlostanova (2008:112)—after positing that modern achievements necessarily engender colonial wounds_-identify mechanisms in Eurocentric science 
designed to create ignorance by glorifying modernity and its perceived progress, on the one hand, while overshadowing — or even erasing — colonial wounds (i.e. contradictory or uncomfortable truths) (Bhabha 1984; Cooper 2005; Halperin 2015), on the other. This is captured, to give a basic example, in rhetoric of how Great Britain introduced law and order to its colonies. Homelessness itself—in the context of Eurocentric science-has long been conceptually understood as a mark of social and spatial disorder. So, how does one challenge Eurocentric conceptions of homelessness-those that deliberately define it as a hindrance to a glorified social and spatial order achieved under modernity—while also making visible the colonial wounds that these conceptions of order hide? How could we best understand the ideas and institutions we have for managing homelessness as an extension of our imperial and colonial pasts, and a product of our contemporary global political economy and culture? How could understanding homelessness and related policies in this way improve our systems for addressing homelessness in Kuala Lumpur and Tokyo, or Malaysia and Japan, or other "ordinary cities” globally today?

Moreover, under contemporary neoliberalism in Malaysia and Japan, depressed wages, rising costs of living, and increased responsibilization of individuals and families have propelled larger numbers of people into socioeconomic precarity and homelessness. Yet, the fundamental conception of what homelessness is and how it ought to be addressed has changed only marginally over the last 150 years. Fundamentally, welfare policies, in particular, seek to adapt people to capitalist markets—by encouraging new labor skills, "motivating” workforce participation, ensuring financial literacy and proper household formation, as well as "enlightened" embrace of modern responsibilities. In my research, I will illustrate how current trends in homelessness policy tap into historically 
established institutional arrangements and their ideational underpinnings, all-the-while driving unique policy variations and street-level experiences in Kuala Lumpur and Tokyo.

Research objectives

As I explore shifts in the configuration of homelessness regulation in Kuala Lumpur and Tokyo, I am also mindful of the relation of change from the mid-nineteenth century on to global governance networks and strategies. In conducting such research, I take into account the influence of ideas, institutions, and uneven power relations at the transnational scale, and thus aim to bolster both policy scholarship and urban scholarship “at a world scale” (J Robinson 2011: 1) by considering city strategies beyond EuroAmerican contexts. The field of policy mobilities—albeit concentrated on contemporary neoliberal matters—takes a similar approach to studying agents and processes that produce ‘local globalness' (McCann 2011) in policy at any given site. However, here too scholarly attention is focused on liberal welfarist structures and Euro-Americentric frames. Ananya Roy (Baker et al 2016) makes the point that, because of differences in structures across First and Third World states, comparative policy studies must incorporate more historical analysis for illustrating the shifting geographies of each region's statecraft. Without templates of prior state forms and functions, she explains, we cannot fully gauge forces transforming governance. Hence, understanding neoliberal transformation requires consideration of prior assemblages of governance to measure policy uptake on its own terms (Bunnell 2015). 
In my dissertation, I achieve this through examination of three central questions:

- What idea and institutions shape policy development and how does their application differ across post/metropolitan and post/colonial contexts?

- What are past and present street-level impacts of such policies, particularly on persons experiencing homelessness?

- What implications do policy structures have for individual and collective human securities?

I investigate and answer these questions using global historical and ethnographic research methods including archival ethnography, participant observation, interviews, historical process-tracing, and action research as described below.

Research design and methods

To answer the above questions while achieving my stated objectives, I look at the production of homelessness and its regulation in each country by adopting postcolonial concern for understanding structures through subjects (Bhabha 1984; Mbembe 2001), including a view of the city as a subject of history. At the same time, I adopt global historical methods for analyzing processes, policies, and urban environments (read: cities) as constructed on their own localized terms while acknowledging wider global conditions (Bhambra 2010) and the global field (Go 2008) influencing political, economic, and cultural changes. This includes seeking “connected histories” (Bhambra 2010; Chakrabarty 2000; Patil 2017) that trace the links between imperial and colonial era formations and their re-formations as mediated by global and transnational circuits. 
Research design and methods involve interdisciplinarity to facilitate study of processes that are simultaneously historical yet also contemporary, global yet also local, transnational yet also socio-spatially-specific, social yet also political-economic, scientific yet also cultural, and so forth.

Archival research is the foundational component of my research design. The archives are an important source for data; archival records offer views into past knowledge—and knowledge production—-pertaining to homelessness and its regulation. I adopt an ethnographic approach to archival research that involves methods of treating the “archive as subject” (Stoler 2002) by reflecting as I read material both with and against the grain (Stoler 2009). Data have been collected from materials ranging from policy documents, legislative debates, agency reports, non-public communications, and demographic surveys. An ethnographic approach supplements "hard" data on specific policy-related laws, practices, and institutions found in such materials with the "soft" context of values, beliefs, and ideas that cohere these artifacts and practices into a working system. The combined use of descriptive and inferential data in my qualitative analysis of archival materials fits well with process tracing methods (Jacobs 2015) that I adopt in later stages. Archival research sites include the University of Malaya Law Library and the Malaysian National Archives in Kuala Lumpur, Malaysia; the National Archives of Singapore and the Singapore National Library in Singapore; and the National Archives, National Diet Library, and Metropolitan Archives in Tokyo, Japan.

After completing archival research, I engaged in twelve months of participant observation, spending six months in each of Tokyo and Kuala Lumpur. In each city, I stayed in rooms neighboring areas where homelessness was historically concentrated: in 
the Sanya area in Tokyo and Chinatown in Kuala Lumpur. My research plans were shaped by an awareness of ethical questions regarding who benefits from research on homelessness and the risk of perpetuating social inequalities, exploiting informants, or exacerbating harm to marginal groups as a researcher (e.g. Borchard 2012). Scholarly works on homelessness that document social processes or lived experiences may not necessarily beget significant change to, or broaden public knowledge of, the same processes and conditions (Lyon-Callo 2012). For this reason, I took inspiration from action research methods (Stringer 2014) and incorporated into ethnographic fieldwork the use of collaborative inquiry sessions designed to facilitate more open, collaborative engagement with people experiencing homelessness. By this design, I aimed to more broadly contribute to generation of knowledge beneficial to not only my own research, but also to others' strategies and lives.

My methods for collecting data relating to questions on ideational and institutional constructs, street-level policy impacts, and implications for human securities were: participant observation, collaborative inquiry, and semi-structured interviews. For participant observation, my primary aim was to examine the interface between policy, practice, and policy impacts on people’s daily lives. I adopted Snow and Anderson's (1987) ethnographic "perspectives of action” and "perspectives in action” as frames for ethnographic data collection. "Perspectives in action," refers to individual views of and responses to government policy at the time that interactions with officers and artifacts occur. I would "go along” (Kusenbach 2003) with interviewees and stay outdoors to observe both daytime and night-time policy enforcement. As interviewees engaged officers, artifacts, and "political technologies" (Shore and Wright 1997), I took notes on 
their “perspectives in action”. I then expanded on this data by probing interviewees' postfactum reflections, or "perspectives of action" in interviews and collaborative inquiry sessions (outlined below). Data from interviews and field notes were organized in an NVivo project with archival and documentary data and coded to classify ideational and institutional bases in policy and their impacts.

Collaborative inquiry is a participatory activity designed to bring people into the inquiry process through the creation of spaces for sharing and generating multiple forms of knowledge, including that experiential, presentational, propositional, and practical (Reason 2006 2014). I arranged small (approx. 3-10 persons) “open-air” collaborative inquiry sessions, usually facilitated by one or two participant informants. Facilitators guided the exchange of information or questions, relating to research themes as I shared or otherwise made my own archival and ethnographic findings available. Sessions were meant to explore participant perspectives on policy, policy impacts, state objectives, and interactions with state agencies and civil servants. This forum expanded opportunity for the emergence of new knowledge and ideas relating to policy and its relationship to local and global political, economic, social, and cultural factors.

I also conducted semi-structured interviews with public- and civic-sector policy agents as well as persons experiencing homelessness in each country. In Japan I interviewed government officers responsible for national-, metropolitan-, and ward-level policy formation and implementation about contemporary policy and its effects. This included officers from the Taito Ward Urban Planning and Parks Section, the Taito Ward Welfare Office, the Shibuya Ward Parks and Greenery Section, the Shibuya Ward Council, the Tokyo Metropolitan Bureau of Construction, the Tokyo Metropolitan 
Bureau of Welfare and Insurance, and two separate offices within the Ministry of Land, Infrastructure, Transport and Tourism's Bureau of Kanto Regional Development. In Kuala Lumpur, I interviewed officers from the Ministry of Women, Family, and Community Development’s Policy Division and Enforcement Division, as well as officers from Kuala Lumpur City Hall—one of whom provided me with a tour of Pusat Transit. In interviewing people with experience of homelessness, I utilized theoretical sampling (Glaser and Strauss 1967) to seek differences in experience by ethnicity, gender, age, and other dimensions of identity to the best of my ability. I interviewed 20 people with experience of homelessness at each site and collaborated with local partners in Kuala Lumpur to secure interpretation for Malay- and Chinese-language interviews and transcriptions.

Analysis

For analysis, borrowing from comparative historical methods, I conducted a withincase historical analysis of each city to trace the embeddedness of certain historical practices in the construction and enactment of policy today. I began with a review of historical data, organized according to era and policy system. Because government records and archival resources emerge from ambiguous processes and power relations that “[contain, obscure, or deny] certain historical truths” (Trundle and Kaplonski 2011:409), I adopted Stoler's (2009) critical approach to qualitative content. That is, I read materials both with and against the grain to best appreciate and scrutinize documented claims for insight into the myriad values, beliefs, pressures, and ideas that animated working systems. I primarily utilized Fingfeld-Connett’s (2014) methodology 
for qualitative systematic review as I concentrated on policy changes over time, and then used process tracing (Mahoney and Rueschemeyer 2003; Jacobs 2015) to infer key mechanisms in the ideational and institutional transformation of homelessness regulation. This included processes of selecting and coding data, memoing, diagramming, and reflection. For instance, I identified regulatory systems by first selecting and sorting data on pertinent institutions, laws, and practices and then conceptualizing policy structures in visual diagrams. Then, I used historical process-tracing to examine key mechanisms in and outcomes of street homelessness interventions across public service agencies.

After within-case historical analysis, I extended inductive study to include analysis of cross-case variation (Lange 2013; Jacobs 2015) and identified key mechanisms and patterns across both countries while also concentrating on contemporary policy and related ethnographic data. I began by reviewing field notes and transcribed interviews to identify codes that offer answers to my research questions regarding: ideational and institutional constructs, street-level impacts, and implications for human securities. After coding ethnographic data, I considered it together with historical data in cross-case analysis to identify: 1) the relative trajectory of key ideas, institutions, and impacts across both countries; 2) the relationship of binational convergences and divergences in policy and practice to local and global factors, and 3) which continuities across policy trajectories are inherent to capitalist socio-spatial regulation functions. Insights from this analysis were then organized thematically and presented according to contemporary policy impacts, namely, within Kuala Lumpur (Chapter 2) and Tokyo (Chapter 3) as well as across public spaces (Chapter 4) and social institutions (Chapter 5). 
My analysis of policy has revolved around key themes that surface repeatedly throughout this dissertation. I introduce the significance of and foundational scholarship on these themes, as relates to the global history of homelessness regulation, below.

The Roots of Policy

Difference

Just as extraordinary poverty was produced from the spread of industrial capitalism throughout Europe-due to expropriation, on the one hand, and the retraction of state systems for poor relief, on the other (Halperin 2004; McLaughlin 2000; C Robinson 1983)—so it was also produced from imperialist territorial expansion in the nineteenth century. For example, England’s gradual colonization of Ireland gave rise to racialized relations between the two that surged as "Ireland [was] transformed into a dependent sector of the English economy” by the turn of the nineteenth century (C Robinson 1983:38). The political and economic powers that rested with colonizers accorded favor to people who were valued more highly under Britain's social order. This uneven balance of power and opportunity shaped the formation of Ireland's industries, legal systems, labor markets and urban infrastructure including housing and health care facilities. As industrial capitalism went global over the course of the nineteenth century such imbalances between imperial (metropolitan) and colonial actors were recreated at the global scale.

The spread of capitalism through Europe via expanding intra-regional exchange was accompanied by the formation of states that entailed drawing boundaries between not 
only territories, but also people. Elite groups expanded their market economies by linking horizontally with outside regions rather than developing local markets. This enabled elite groups to gain wealth through inter-regional trade while also expanding their political reach and power as political participation was contingent on wealth itself (Halperin 2004). Moreover, while dispossession experienced by the lower classes fueled protest often framed in ethnocentric (e.g. linguistic and geographic) terms, competition between ruling, bourgeois, and aristocratic elites led to (proto-)nationalist desires to claim and cohere territories. Therefore, the growth of empires and economies necessarily involved social and political boundary-making, often ethnic and racial in nature. Cedric Robinson (1983:62) argues that the rise of myriad nationalist and ethnocentric sentiments was in fact "a force which has proved definitely stronger in the modern world than the class struggle which for orthodox Marxists makes the essence of history” and, at all scales, racialism and ethnocentricism served as a key organizing structure for expanding European industrial capitalism. ${ }^{16}$

Bayly (2004:199) stresses that as European empires extended to other continents, "tide[s] of nationalism...drew on indigenous legends, histories, and sentiments about land and people" and therefore developed in locally specific ways. For this reason, nationalisms (and socio-political organization in general) should not be viewed as "exports" delivered along with industrial capitalism from the West, but rather as indigenously constructed, often marked by continuities with historically entrenched

\footnotetext{
${ }^{16}$ Mignolo (2000) clarifies differences between the transantlantic expansion of commercial systems and colonial rule into the Americas (i.e. Occidentalism) prior to industrialization and the expansion of the same into Africa and Asia (i.e. Orientalism) during industrialization. Together these comprise a geo-economic order that, nonetheless, carries a qualitatively different character of "coloniality" on each end.
} 
governing structures or cultural or economic systems, or a combination of these. Moreover, Bayly (2004) underscores that, over the nineteenth century, longstanding ${ }^{17}$ globalizing processes and ensuing growth in the global economy "produced a paradox": as movement became freer and covered more territory, it became the focus of more attention, prompting the development of more rigid systems of regulation to control flows between spaces and bodies. Thus, a "nationalization" of territories took place (enabling central coordination of key urban and non-urban zones), creating a foundation by which states became more interventionist. As part of this, laws, institutions, and other technologies for organizing the political economy and society were created, each indelibly shaped by ideologies pertaining to civilization and the "natural order" of things-influenced as they were by transnational exchange. Ultimately, difference itself—as seen between races, genders, (dis)abilities, and so on—became an organizing principle of imperial and colonial systems at global, regional, and local scales.

While the concept of difference was itself not new, it was applied more systematically in the late nineteenth century owing to the rise of social scientific work dedicated to classification—and the ability of states to intervene. As a result, "difference" took a more structural, institutionalized form across social, political, and economic contexts. More specifically, ideas and knowledge drawn from global colonialist projects—or, more importantly, the "othering” that both underpinned and was produced by them—-pervaded scientific, political, and social thought. In particular, race theory and ideas of social hierarchy were popularized at the turn of the twentieth century among

\footnotetext{
${ }^{17}$ Bayly (2004: 42-44) explains in depth earlier “archaic globalization”, a loosely-constructed pre-modern international system of exchange facilitated by the bonds of kingships, religion, and moral understanding of physical health.
} 
academics, scientific experts, government officers, and the public at large through international social science conferences and colonial expositions (Cristy 2004; Siddle 2004; Weiner 1997). Fora such as these advanced and legitimized the classification and hierarchical arrangement of raced, gendered, sexualized, and physically and intellectually (dis)abled bodies, organized at local, regional, and global ${ }^{18}$ scales. These constructs of difference circulated globally and served in both metropolitan and colonial territories as templates for directing the regulation and control of populations.

These constructs, legitimized through social and scientific theory and proliferated in public and government thinking, came to be seen as an intrinsic foundation for social order. Hence, they were woven into ideas and institutions that guided the continuing expansion of capitalist systems and modernization efforts. Historically, the effects of raced, gendered, and otherwise hierarchical modes of thinking and practice have been visible in the economic, social, political, and legal structures of normative orders in both metropoles and colonies: they could be seen in profoundly raced, gendered, and otherwise socially-differentiated divisions of labor (Lowe 2015; Mahmud 2012; C Robinson 1983) including, for example, conditions by which free and unfree laborers traveled, lived, and worked in line with (or in spite of) regulatory schemes (e.g. Driscoll 2012; Lee and Sivanathiran 1996). Scholarship has shown that effects were visible in the management of sexuality (Foucault 1978; Stoler 1995; Woollacott 2006) and health care facilities (Manderson 1996; Swarr 2012), as well as housing provision and the structure

\footnotetext{
${ }^{18}$ Use of scale was demonstrated in practices of grouping and classifying people; for example, Japanese scientists participated in identification of peoples of the Japanese empire according to indigenous and ethnic/caste affiliation, on the one hand, as well as the organization of global populations into European, African, Asiatic, and Malay races, on the other (Weiner, 1997).
} 
of households (McClintock 1991; Watson and Austerberry 1986). It is for these reasons that constructs of difference are not only inextricably linked to homelessness but actually precede and produce it.

Until recent decades, the constructed nature of differences other than those marked by class and/or nation were understated in sociological research (Tilly 1998). Therefore, although regimes of difference such as gender, ethnicity, ability, and sexuality, among others, have historically mediated political, economic, and social processes and played a key role in the organization of the global capitalist order, the presence and effects of such regimes were not often rendered visible in social scientific work, except where they were "naturalized and normalized in the dominant culture" (Seidman 1997:8). The result is that, as Seidman (1997:25) critically notes, even the "progressivist hopes and narratives [of sociology to date] are a part of a dynamic of colonization, and... its language of rights, constitutionalism, and legality in part, conceals disciplinary forms of social control.”

The ramifications of this are evident in literature on poverty and homelessness too, which has for much of its history treated each of the "the poor" and "the homeless" categorically as social classes of their own (O’Connor 2009). For example, while poverty and homelessness were studied as social problems at the turn of the twentieth century, research concentrated on evaluation of the "submerged tenth" or "dangerous classes"or, more specifically, “vagrants,” "beggars,” “vagabonds,” and “tramps,” (Bassuk and Franklin 1992) — who were deemed to be either "deserving” or "undeserving” of their poverty (Cresswell 2001). Such studies generally treated poor and homeless persons as a degraded—and often racialized (e.g. “Darkest England”) (McLaughlin 2000)—class 
"beneath" normative society who were to be uplifted, if worthy, and disciplined, if not, by social reformers and policy agents (Beier and Ocobock 2008; Vorspan 1977; Haggard 2001). Thus, concerns regarding homelessness largely revolved around the presumed moral or cultural (“civilized”) status of the homeless individual or social group—-thereby serving to naturalize and normalize their condition by associating it with individual responsibility and/or inherent capacity. While gender, race, ability, and other factors were also recognized apart from poverty (e.g. "vagrant women," "Native beggars”), such dimensions of social difference were given only secondary concern in terms of their relation to homelessness. That is, one's poverty or homelessness was naturalized or normalized considering one's moral character or inherent capacity, and this character or capacity could be further explained (read: naturalized and normalized) for marginal groups by their inherent (biologically-, culturally-, or environmentally-determined) deviance from "civilized” norms (e.g. as "unsettled Natives," or "promiscuous women” ${ }^{19}$.

From the mid-twentieth century, homelessness studies began to direct greater attention towards the social structural roots of homelessness and looking beyond individual responsibility (Pleace et al 1997). As part of this shift, scholarship today has directed greater attention to processes of racism, sexism, ableism, and other forms of discrimination or exclusion as they affect particular social groups. However, considerations of gender, race, sexuality, ability, and other differences often remain

\footnotetext{
${ }^{19}$ However, early studies did nonetheless allow for some consideration of structural factors and social processes producing homelessness such as: a) economic downturns, labor exploitation, and other occasions that could not be traced to the fault of the "deserving" poor, or b) social sanctions against, or rejection of, the insiduous behavior or nature of the "undeserving" poor.
} 
secondary; in other words, homelessness as a phenomenon is theorized as existing apart from social difference but with outcomes exacerbated by social difference ${ }^{20}$, which obscures the relation of gender, race, sexuality, ability, and other such categorical differences intrinsic to homelessness’ production. As a result, dominant approaches to studying homelessness of marginalized groups and individuals (e.g. "the mentally ill”, “single mothers") and implementation of policy ${ }^{21}$ continue to involve "naturaliz[ing] and normaliz[ing]” (Seidman 1997) the homeless state of the group by positing that the deviation of the individual from broader norms is at the root of the homelessness (e.g. a woman’s lack of a breadwinner, a person's lack of medication for their mental illness), rather than posing questions regarding the beliefs and norms that underpin their exclusion. These approaches propagate the idea that such groups (and homeless populations in general) need continued moral supervision via policy (Mohr 1998). Over the last two decades, increased attention has been directed by scholars to this “responsibilization” of individuals for their homelessness (Dej 2016; Whiteford 2010) or the “medicalization” and “pathologization” (Lyon-Callo 2004; Mills 2015; Willse 2015) of experiences of poverty and homelessness, which, in essence, justify homelessness as a destiny or condition rooted in the individual. Lyon-Callo (2004:19) posits that, under such a system, “the 'natural' processes of social inequality remain largely unchallenged”; I would add that they simultaneously remain underexplored. Processes that produce

\footnotetext{
${ }^{20}$ For example, as due to insufficient stocks of affordable housing in a given locality, which then disproportionately impacts “minority” groups (see Wolch and Dear, 1993:20-27). Conversely, I believe the emphasis should lie on the racist, sexist, and otherwise exclusionary nature and aims of policy guiding housing production historically.

${ }^{21}$ For discussion of how dominant approaches to policy practice today naturalize and normalize homelessness, see Lyon-Callo (2004) and Beckett and Herbert (2010).
} 
social difference must be viewed in their proper context as forces at the root of — and inseparable from - the production of homelessness.

In his exploration of “durable inequality”, Tilly (1998:7) puts forth a model for understanding how "significant inequalities in advantages among human beings correspond mainly to categorical difference, such as black/white, male/female, citizen/ foreigner, or Muslim/ Jew rather than to individual differences in attributes, propensities, or performances”. Fundamentally, his model explains how groups are distinguished, defined, and organized using social discriminators, which then serve as the basis for exploitation, opportunity hoarding, and other "social mechanisms...[that] lock categorical inequality into place”. Such perspective shows that inequalities borne from difference become durable as they are reinforced via institutions and practices across time. Nonetheless, the categorical differences that underlie social organization are not stable or solid entities; rather the boundaries that define and contain social groups are inherently ambiguous and shift over time (Sibley 1995; Tilly 1998).

Tilly (1998) gives numerous examples—both historical and contemporary_of how the creation and maintenance of categories has been used within social structural systems to preserve advantages for a social elite. His work corresponds in many ways to approaches to the construction of "the other" or otherness as seen in postcolonial studies. For example, Homi Bhabha (1984:19) argued that social difference was an axis on which colonial exploitation was possible as: "construction of the [subject] in discourse, and the exercise of colonial power through discourse, demands an articulation of forms of difference —racial and sexual”. Bhabha also identifies the "fixidity" of categorical boundaries as paradoxically known in stereotypes yet never fully true, thus requiring 
constant redefinition and refashioning. In Colonialism in Question, Cooper (2005)

highlights postcolonial contributions to scholarship on difference stressing:

“Modern” empires were in some ways more explicit about codifying difference - and particularly codifying race - than aristocratic empires, for the giving way of status hierarchies to participation in a rights-bearing polity raised the stakes of inclusion and exclusion. Just where lines of exclusion would be drawn - in terms of territory, race, language, gender, or the respectability of personal or collective behavior-was not a given of the "modern state," but rather the focus of enormous and shifting debate in nineteenth and twentieth century Europe.

Thus, while boundaries defining categories of difference and exclusion shift, these can be recognized in public and government debates guiding change in ideas and institutions.

\section{Liberalism}

In The Birth of Biopolitics, Foucault (2004) explains that liberalism transformed modern governance by introducing a new rationality, namely, one that defined economic processes as governed by a quasi-natural order (such as Adam Smith’s “invisible hand”). In liberalism, the free market is defined as a realm that must in fact be left to its natural processes, without interference by government; thus, in theory, it becomes incumbent on government to limit its own powers and manage the economy in ways that enhance prosperity for the state and its subjects. Because of the advance of liberalism as a rationality, the scope and form of the state's powers shifted from what they had previously been in the feudal era; for one, while the economy remained a concern of the state, the state could no longer directly control or intervene in its institutions, now considered to belong to a private, and apolitical, realm. Instead, it needed only to treat them administratively (Agamben 2011). In effect, the modern state was understood to be not unlike "an 'enterprise' just like a factory" (Weber in Comaroff 1998). 
At the same time, these changes transformed state governance over its subjects. In his lecture from April 4, 1979, Foucault (2004) explores the relation between governance, the economy, and civil society. First, he establishes government as an organic extension of civil society (and therefore not a contrary force). Then, he (2004:296) defines homo economicus as an "economic point that inhabits the dense, full, and complex reality of civil society" while also recognizing civil society as "the concrete ensemble within which these ideal points, economic men (sic), must be placed so that they can be appropriately managed." (italics are mine) Therefore, for the state to ensure prosperity, which is determined through the function of the economy, it must manage “economic men” and (enforce) their place in civil society. As a result, state management of the economy is entangled with its management of society, and vice versa or, in the words of Foucault (2008:296), “homo economicus and civil society belong to the same ensemble of the technology of liberal governmentality.” This links into his discussion (2008:67) of biopolitics in an earlier lecture where he states, “Economic freedom, [that is,] liberalism in the sense I have just been talking about, and disciplinary techniques are completely bound up with each other.”

Police and the maintenance of order

In The Fabrication of Social Order, Neocleous (2000) details the history of the police as a core force in the maintenance of social order from feudal to modern times in Europe. In particular, he notes that the introduction of liberalism as a rationality of government required “a rethinking of the police concept in new, liberal terms.” That is, 
across time police and policy have consistently served as state instruments for ensuring security $^{22}$, but prior to the nineteenth century this meant intervening in food production and overseeing markets to ensure public order and welfare vis-a-vis the smooth distribution of food as well as security by preventing riots. As feudalism disintegrated and peasants were dispossessed of the commons, police became responsible for mobilizing “masterless men” into work (Neocleous 2000; Piven and Cloward 1993). Neocleous (2000:16) elaborates that, by the time liberalism was introduced into governance, feudal police obligations to guard and enforce welfare were removed. In Punishment and Welfare, Garland (1985:46) speaks of this same transformation as follows.

[L]iberalism, and its strict division between public and private spheres, specified that [questions of] welfare were private matters, unsuitable for state concern... [and thus the domain of] private agencies... Much care was taken ensure that agencies dealing with welfare [- like] reformatories [and] discharged prisoners' aid societies - retained their private status and reputation, even when they were a de facto element in the normal routines of penal practice... [Welfare] was in no sense the duty, responsibility or proper concern of the Liberal State.

As neither the state nor the police were responsible for public security vis-a-vis welfare, unlike prior centuries where they assisted distribution of food, police duties were limited to ensuring security vis-a-vis public order (Neocleous 2000). In this regard, laws and the "rule of law" grew in importance such that police became protectors and enforcers of law, positioned to act not as direct agents of the state (as before) but as arbiters for the state in the interest of law. Because the liberal system of freedom was founded on

\footnotetext{
${ }^{22}$ And, moreover, largely indistinguishable from each other until the $16^{\text {th }}$ century. Thus, in historical legal studies, "police” or "policy" are used interchangeably.
} 
principles of property (including one's labor as one’s property) as a right and essential to life, legal and policing systems served to ensure its protection.

The liberal system—organized around the protection of property—in many respects cemented and perpetuated social and economic inequalities. Ideologically, liberalism espoused a universalism, one of a horizontal community in which every homo economicus was equally free. By the same token, all persons who were economically active could, in theory, claim freedom. However, despite this premise of egalitarianism, in reality, those with only their labor to sell were not equally free; rather, they were inserted in a hierarchical relationship with "his or her master, the owner of the means of production” (Gordon 1991:28) who possessed under liberal "rule of law” a largely unregulated power as a private sector actor. The state, concerned with the management of land and the production of value, left the (social) security and welfare of workers—all matters outside of its realm of administration—-to employers and other private associations.

However, the state, concerned as it was with ensuring state prosperity and (public) order, sought to achieve both by mobilizing labor. On the one hand, this was historically achieved through master and servant legislation (later to become labor legislation), distinguished by the stringent leveling of penal sanctions against servants/employees for breaching contracts over breaches by masters/employers (Hay and Craven 1993). On the other hand, this was also achieved through policing vagrancy — an important task at a time of massive poverty owing to widespread displacement and dispossession. Forcing vagrants into wage labor was believed to reduce crime since, it was argued, income prevented people from choosing to meet their needs 
through crime; on the other hand, by forcing unemployed persons to perform labor in workhouses, the state was able to keep wages low while also capitalizing on reserve labor pools ${ }^{23}$ by contracting them out to private employers and public projects, among other things (Garland 1985; Neocleous 2000; Piven and Cloward 1993).

By construing “idleness”, or individual failure to capitalize on one’s labor, as a threat to public order, the state endowed police with power to directly govern over "men and things” (Dubber 2005). In Manhunts, Chamayou (2012) dedicates a chapter to the history of "hunting the poor" and homeless through police sweeps and patrols. He asserts that hunting for the poor was justified through blaming victims by characterizing their presence as insidious ${ }^{24}$ while also claiming that capture/arrests and punishment helped to inculcate freedom "by taming their nature" (52). In other words, crackdowns on the poor and homeless fit onto a broader paternalistic order which requires that, before people may be considered emancipated, they must achieve the "ontological responsibility" or "selfgovernance” (Chamayou 2012:53) they are presumed to lack. Manhunts for the poor were fueled by both punitive intent and coercive benevolence determined by police discretion. Social reformers and voluntary associations also wielded punitive intent and coercive benevolence but in their capacity as guarantors of the welfare of the poor (Haggard 2001; Hansen 2007). Thus, in tandem with the rise of scientific study and professional specialization pertaining to matters of poverty, classification of poor people

\footnotetext{
${ }^{23}$ As stated by Foucault $(1988,229-230)$, "poverty was necessary too because it made wealth possible. Because they labor and consume little, those who are in need permit a nation to enrich itself... [I]n short, a people would be poor which had no paupers.”

${ }^{24}$ As Garland (1985:17) notes, "the twin doctrines of individual responsibility and presumed rationality" crafted a belief that "the criminal actor, like his economic counterpart, [homo economicus] was deemed to be in absolute control of his destiny.”
} 
into "dangerous categories and categories in danger" was reinforced broadly throughout public, private, and civic sectors (Fassin 2015)

Welfare and social control

Reforms in poor laws across Europe over the nineteenth century [as explained in detail by Dean (1991)] involved a reduction of state responsibility for welfare, primarily by narrowing "eligibility" and institutionalized more rigid enforcement through private associations. Stated differently, police function was attached to two parallel systemsone penal and one welfare-and policing in each grew even more vigilant in its strategy and technique for regulating the poor. Welfare agents, like police, were expected to enforce laws and policy as arbiters for the state.

Numerous scholars including Dean (1991), Foucault (1988), Garland (1985), Piven and Cloward (1993) and Rusche and Kirchheimer (1968) have illustrated the common roots of and parallels between the juridical and welfare models of punishment prominent in the nineteenth century. Dean, for one, stresses that these systems emerged not from class relations (as theorized by Marx) or religious moral values (as theorized by Weber) but, rather, from the emergence of the liberal and patriarchal ethos of "selfgovernance”, which demanded that wage-laborers engage in labor in formal markets. Garland (1985:48) details that welfare recipients (who, by definition, violated these imperatives) were subject to a "denial of citizenship"; that is, people who accepted aid were obligated to "relinquish [their] private freedom [and] quit the political community [to occupy] the status of outcast or pariah” in the workhouses and asylums. Garland (1985:48) also notes that this "negative, repressive axis of the disciplinary network 
[targeting the poor]" was operative in both systems of welfare assistance and penal sanction.

In many cases, state aid and private/civic aid were necessarily contingent on work, as labor was considered "an infallible panacea, a remedy to all forms of poverty" (Foucault 1988:55). Piven and Cloward (1993:29-30) explain,

To cope with [disturbances of rising poverty and unrest], relief expanded... Everywhere, however, the main principle was the same: an unemployed and turbulent populace was being pacified with public allowances, but these allowances were used to restore order by enforcing work, at very low wage levels... Conditions in the workhouse were intended to ensure that no one with any conceivable alternatives would seek public aid.

This proliferation of policing via state, non-state, and quasi-state channels of aid provision gave rise to "the modern nation [and] an unprecedented extension of the organizational and moral community"; such developments would not have been possible without "the penetration and continual presence of central political authority throughout daily life.” (Silver 1967:12-13)

From the early twentieth century, poverty management in metropolitan regions shifted in response to the proliferation in science and politics of eugenic concern for social degeneration, presumably caused by modern urban life (Garland 1985; Rusche and Kirchheimer 1968). Imperial states began absorbing responsibility for social welfare and gradually transformed into "welfare capitalist states” (Epsing-Anderson 1990). This shift included not only increases in public aid but also the integration of rehabilitative ideals into penal policies, resulting in what Garland (1985) terms the hybrid "penal-welfare complex”, which lasted through the 1970s. However, these largely rehabilitative systems emerged not from an interest in resolving poverty per se; rather they were designed to 
organize and stabilize a national labor force through a new "familialization” (Orloff 2005) of the social order. That is, the state "both regulated and supported" (Orloff 2003:231) breadwinning at the household level by developing a state welfare apparatus that legitimated and enforced paternalistic social divisions of labor (Haney and Pollard 2003). This extension of law and policy into social economic organization enabled private and public sector agents to more rigidly enforce paternalistic norms of social difference at the household level based on gender, sexuality, nationality, marriage status, and formal (as opposed to informal) labor market participation, among other things (Orloff 2003, 2005).

Lawfare: Law and coercion

Jean and John Comaroff, scholars of post/colonial governmentality and the post/colonial legal cultures, have advanced the concept of lawfare to explain the ways in which law has been used as an instrument for imposing a fabricated, patriarchal order over colonized people and places to consolidate political power and facilitate the extraction of labor and wealth. The use of law as a coercive tool is possible, they (2006:30) argue, because legal instruments—-from legal code itself to its execution through policing and the courts—collectively serve as "means of violence ${ }^{25}$ rendered legible, legal, and legitimate by [law’s] own sovereign word.” Thus, Comaroff and Comaroff (2006) stress the power that colonial governments exercised over human life and political existence while law obscured its own complicity in creating inequity and

\footnotetext{
${ }^{25}$ For more on state monopolies on legitimate violence as promised through law, see Harcourt (2010), Hussain (2009), Leonard (1995), and Tilly (1985).
} 
violence. Correspondingly, Comaroff (2001) argues that law is a mode of domination imposed in the name of civilization and progress ${ }^{26}$, as well as a site of resistance for people subordinated to colonial systems. James Fitzjames Stephen, a nineteenth century political philosopher and British high court judge, declared that the purpose of law in colonial society is, "the sum and substance of what we have to teach them. It is, so to speak, the gospel of the English, and it is a compulsory gospel which admits of no dissent and of no disobedience.” (Hussain 2003:4) For this reason, law and policy produced through negotiations between colonial agents and colonial subjects capture the social and moral ideas, norms, and practices that produced the colonial state. Moreover, because of particular colonial ideologies and institutions—including those valuing raced, gendered, classed, (dis)abled, and other people of "difference” in divergent ways—law and policy were "applied to multiple statuses and juridical subjects differently....often beyond judicial inquiry” (Hussain 2003:6).

In her exploration of colonial legal pluralism ${ }^{27}$ in Law and Colonial Cultures, Benton (2002:253) also echoes analogous views that "the colonial state was in no small part the product of the politics of legal ordering”. Her book emphasizes that colonial legal orders were fashioned from ideologies of difference, racial supremacy, and the essential

\footnotetext{
${ }^{26}$ Imperialists and colonialists believed that non-European cultures lacked "a modern sense of right-bearing selfhood" (Comaroff, 2001:306) and adequate capacity for self-governance within the context of their own socio-political orders. This view justified the imposition of western legal orders on their communities within colonial territories.

${ }^{27}$ Generally defined as the co-existence of multiple legal systems, as developed in colonial cultures, to allow for differential governance over matters of importance to the colonial administration and "native" subjects. Benton (2002:22) explains, "Colonial legal policy relied on familiar categories in distinguishing between property disputes that were central to colonial interests and should therefore be handled in courts dominated by colonizers, and property transfers that could be properly viewed as familial, religious, or culturally specific and could be safely relegated to other forums.”
} 
“order” of social hierarchies (also see Chatterjee 1993; Hussain 2003). In turn, she explains, these legal systems underpinned the definition and distribution of local property rights, for example, which profoundly shaped social organization and cultural norms while also linking colonies to an international order of accumulation and exploitation based on coercion and violence. Comaroff (2001:309) provides a clear view into the ways in which international trade, liberal thought, and sociocultural transformations intersected with colonial law as the latter set in motion "a process that made spaces into places to be possessed, ruled, improved, [and] protected" while laying out how the world was “constructed and valorized" and how colonial subjects "were construed, ethnicized and racialized, their relations with other human beings, to the earth, and to their own cultural practices delineated”.

In fact, Comaroff (1998:329) differentiates the legal system that emerged in colonial contexts from their metropolitan counterparts by underscoring that, whereas the latter were assigned "the ideological work of manufacturing sameness, of engendering a horizontal sense of fraternity; the [former], despite its rhetoric of universalising modernity, was concerned with the practical management, often the production, of difference" based on imperatives of "govern[ing] development and discipline among natives”. In other words, legal systems, legal codes, and their enforcement in colonial spaces were meant to administer to numerous "populations" and "nationalities" but only while explicitly erecting divisions and enforcing strict hierarchical relations among them. This is evidenced by the structures of legal pluralism itself (e.g. the subordinate position of traditional courts to modern ones) as well as the proliferation of laws and policies that 
distributed rights and protections differentially according to nationality, ethnicity, and race, among other things.

Now, as specifically relates to poverty management, it was standard practice prior to the mid-twentieth century for colonial administrations to fund urban policing and public security measures, which included sweeps ("manhunts”) and arrests of "beggars and vagrants," while guaranteeing the social welfare of only government officers, who as a rule predominantly hailed from the dominant (e.g. European) racial group. Because the colonies relied almost exclusively on the labor of non-Europeans, often hailing from “native” or migrant populations, “master and servant [read: labor] acts were coupled with vagrancy, pass, police, prison, and other legislation to attract, control, and direct flows of labor” (Hay and Craven 2004:24). Responsibility for the social welfare of indigenous and migrant groups was delegated to leaders of their respective non-European communities and justified by the liberal and colonial ethos of "self-sufficiency” (Midgley 2011). Exceptions did exist, such as hospitals for non-European paupers, but these generally served the specific purpose of advancing colonial interest in exploitation and accumulation (MacPherson 1982).

In the mid-twentieth century, imperial powers became more interested in “colonial development” and began introducing social services agencies into colonial governments in the 1940s and 1950s. However, these were typically underfunded, reactive, and at best piecemeal attempts to quell local unrest, and have been described by Midgley (2011:199) as "largely inappropriate, inequitable and marginal to the needs and circumstances of the majority of the population [making only limited] impact on people's well-being.” Thus, whereas poverty management in imperial states had been 
characterized by its welfarist approaches by the mid-twentieth century, it remained largely in the hands of police and juridical systems in colonial and postcolonial states ${ }^{28}$. As a result, the advent of neoliberalism, too, has had a different effect on poverty management in postcolonial countries: although "small government” has indeed been taken up as a mantra in many such countries, changes are rarely directed at alreadyneglected welfare systems and, instead, concentrate on economic, administrative, and legal systems manifested, for example, in liberalization, privatization, and deregulation (Comaroff and Comaroff 2006; Midgley 2011)

Discrimination, discretion, and homo sacer

In the Fabrication of the Social Order, Neocleous (2000) explains that police have historically possessed a general mandate of order maintenance. Moreover, he advances the idea that the execution of the order maintenance mandate relies on the practice of discretion as authorized through law. He (2000:100-1) summarizes as follows.

'[D]iscretion' in practice involves discrimination in the form of selective lawenforcement and order maintenance... [The] discriminatory nature of discretion therefore has its foundation in the permissive structure of law and the powers given to the police to preserve order.

His point in presenting this view is to underscore how the existence of discretion insulates the state and its systems—-such as the penal and welfare systems—-from accountability for discriminatory and unequal outcomes; it serves as the primary field in which universal policies and protections may be applied by entrusted authorities in nonuniversal ways. Should problems arise, it is only individual agents that are questioned. As

\footnotetext{
${ }^{28}$ Except wherever communalist or alternate approaches emerged, such as in India.
} 
Neocleous (2000:104) states, "challenges to the welfare system become focused on questions of maladministration in the exercise of discretionary power, while... challenges to the police are turned into debates about individual acts of individual officers and whether they used their discretion in the most 'reasonable' way.”

Scholarship on the history of police and the origins of modern criminal justice systems emphasizes that neither police nor law were, in reality, designed to uphold justice; rather, each have roots in liberalist desires "not to deliver justice so much as to sustain a right moral and social order with property at its center" and, thereby, to ensure "the welfare of the community" [read: public security and order] ${ }^{29}$ (Gatrell 1996:518; also see Benton 2002; Failer 2002; Dubber 2005). In her monograph on the rights of homeless persons with mental illness facing commitment, Failer (2002) notes that, for centuries, not only were "homeless people" labeled as social threats, but other groups such as persons with mental illness too. She explains that, as a result, individuals and groups have each been assigned different "bundles of rights” within the legal system to facilitate their policing. She (2002: 33) highlights the roots of these practices in liberal philosophy such as where, for example, John Stuart Mill limits his definition of liberty to people in "the maturity of their faculties" thereby denying equal liberty to children, people that "require being taken care of by others," and—in a nod to colonialism—people in "backward states of society" ${ }^{30}$. She also notes that Kant outlined identical views,

\footnotetext{
${ }^{29}$ Similarly, Neocleous (2000:110) states that, "[J]ustice has never been the primary value to which law devotes itself...[Instead, that value] has been order.”

${ }^{30}$ Tellingly, Mill (2002:8) follows this assertion with an explanation that "Despotism in a legitimate mode of government in dealing with barbarians, provided the end be their improvement".
} 
denying full liberty to "passive citizens" such as women, children, and other “dependents”.

Such philosophical views have had vast consequences for numerous groups deemed as being “in need” (Failer 2002) of special paternalistic protection and governance. Such protection and governance is: 1) rooted in the state authority of parens patriate, which enables the state as exercised through the courts to make decisions on behalf of persons deemed incapable of self-governance, and 2) implemented through the "notion of police as state household governance" (Dubber 2005:xv). Historically, such groups have included persons with mental illness, single mothers, alcoholics, and juveniles and, as Failer notes, such governance necessarily denies them "regular rights". At the same time, as paternal protector, the state may extend special "protections" via welfare systems thereby "construct[ing them and their] needs according to certain specific —and, in principle, contestable—interpretations, even as they lend those interpretations an aura of facticity that discourages contestation” (Fraser 1989:146). Here, there is a slippage between policing and protecting subjects constructed as insufficiently "mature" to exercise their full agency as citizens in a liberal political economy. Thus, social policy is discursive in the same ways that criminal justice systems are because both—separately and together—construct "dangerous categories and categories in danger” (Fassin 2015:2). Welfare systems, like penal systems, “may be privileged as central determinants of how systems of power and domination are perpetuated in society as a whole.” (Mohr 2014:211)

Of pertinence to understanding political inequalities produced by socially constructed difference here is the concept of homo sacer (and bare life), advanced by 
Agamben (1998). Agamben explains homo sacer as people rendered into "bare life," simultaneously sacred and accursed ${ }^{31}$, and who are for that reason denied political existence in modern society. He explains homo sacer's role in the modern juridicopolitical order as something of a paradox: "That which is excluded from the community (i.e. homo sacer) is, in reality, that on which the entire life of the community is founded" (17) Agamben explains this paradox through the lens of Foucault's biopolitics. Agamben (1998:119) posits that politics itself inevitably calls the existence of modern man into question, which runs parallel to Foucault's (2008) assertion of biopolitics and state power "to make live and to let die". He adds that "If life, in modern biopolitics, is immediately politics, [then] this unity... appears as an indissoluble cohesion” and homo sacer-the one who is deprived of political existence, and therefore reduced to "bare life"-is one who all people possess political power over, and one who they may deprive of life. Agamben (1998:88) elaborates by stating that, by abandoning homo sacer, sovereign power (read: the state) demonstrates how sacred life is; the importance of life in politics is made real "not [by] simple natural life but [by] life exposed to death”. Marginalized groups in the modern legal and political order are, like Agamben's homo sacer, included in society only by their exclusion. Purity, or absolute order, in the social collective requires their elimination, thus they are "that on which the entire life of the community is founded,” yet they are produced by the order itself. As one example, Agamben (180) highlights the "poor classes" simultaneously scorned and pitied, purged and produced globally through the "democratico-capitalist projects" of development. This

\footnotetext{
${ }^{31}$ Sacred as in pitied, for example, and accursed as in scorned.
} 
conceptualization of homo sacer and their reduction to "bare life" illustrates the process that selectively reduces people, through discrimination, to conditions of political exclusion and economic poverty, which may lead to homelessness. It also shines a light on the particular power "to make live or let die" that not only the state—-but also society—exercise over homo sacer.

In Citizens without Shelter, Feldman (2004:5) poses the question of why people experiencing homelessness "need to be contained, enclosed, disciplined, or excluded" (italics in original) and pursues an answer through the lens of homo sacer. He identifies portrayals of people experiencing homelessness as vacillating between those of the "profanely free (justifying criminalization)" and the "sacralized, helpless sufferers (justifying shelter)”. He (2004:18) nods to Agamben's assertion that bare life is the foundation of the civic body, and adds that state policy, in the face of the existence of "homeless bare life” must "recover the fiction of 'the people' as a unity, of bare life as fully morphed into the citizen [and p]olicies of exclusion and containment.... are one example of this process.” From here, Feldman does what Agamben does not do. Whereas Agamben (1998) focuses on bare life as life that is sacrificed, exemplified in his exploration of Nazi concentration camps, and therefore made “victims” (in Feldman’s words), Feldman (2004) takes the persecution of bare life as an opportunity to analyze the production of "normal" subject, on the one hand, and marginal status, on the other ${ }^{32}$. Specifically, he (2004:20) highlights that "[h]ome dwelling citizen and homeless bare life are political [not social] statuses" and that the liberal state produces these "mutually

\footnotetext{
${ }^{32}$ He states that, "Outlaws of various forms are not the victims of particular injustices but rather signifiers of a new universal condition."
} 
constitutive categories of home-dwelling citizen and homeless bare life.” These statuses, he continues, are produced by law, which “'eliminat[es] the evidence' of its own involvement [by] pretending to re-cognize a pre-existing sociocultural or personhood status 'out there.”' He (2004:22) offers that the creation of a universal rule by which all people must inhabit normative homes creates "homeless bare life" by its denial of any (potential) plurality; therefore, “[t]he dream of proper homes—even in its redistributive progressive form - is implicated in the production of bare life when grand schemes for ending homelessness are based on the destruction or conversion of nonnormative dwellings such as residential hotels... and homeless encampments”. Such a view underscores the substantive meaning and impact of systematic discounting of "bare life," or, stated differently, the consequences of social being deprived of political existence. Such a reading calls into question of suitability or "justice" of any socio-legal response to homelessness that does not simultaneously affirm the social and political existence of "homeless bare life". In other words, the root of ineffective policy lies not in penal or therapeutic approaches_-or any combination thereof—-but rather in the deprivation of political existence. 


\section{CHAPTER 2. IMPERATIVES OF CARE AND CONTROL \\ THE REGULATION OF HOMELESSNESS IN KUALA LUMPUR - 1880S TO \\ PRESENT}

Introduction

In April 2014, Malaysia’s Ministry of Women, Family, and Community Development announced plans to criminalize begging by amending federal vagrancy law, the Destitute Persons Act. As explanation, Minister Rohani emphasized the importance of an aggressive approach, asserting: “It has to be severe, otherwise it wouldn’t be a deterrent." (Nurbaiti 2014) Two months later, the Federal Territories Ministry proposed bylaws aimed at establishing a homelessness-free zone in Kuala Lumpur's commercial Golden Triangle by banning food distribution and almsgiving. That same week, Minister Rohani announced the launch of a month-long sweep called Operasi Qaseh, or "Operation Generosity" in honor of Ramadan, to clear the capital of visible homelessness through anti-vagrancy crackdowns and compulsory relocation of arrestees into "rehabilitation centres" outside Kuala Lumpur (KL). In the press, public officers offered that such measures were integral to achieving "zero homeless".

Begging and homelessness are treated as a set in Malaysia based on vagrancy law, a consistent force in urban regulation since the nineteenth century. The Destitute Persons Act defines destitute persons as "person[s] found begging...[or with] no visible means of subsistence" under the jurisdiction of Rohani’s Ministry, the lead agency for social welfare. Government's embrace of punitive sanctions could be read as the revanchist city 
drawing near. Is Malaysia undergoing a “punitive turn”? Has neoliberalism’s global creep beckoned an escalation of the "culture of control” (Garland 2001) in homelessness politics in Southeast Asia?

These are fair questions rarely posed for cities outside the global North. When "punitive turn" scholarship emerged in the 1990s, focus rested on Euro-American developments signaling a "reversal of a settled historical pattern...towards 'rationalization' and ‘civilization’” (Garland 2001:3) in penal and welfare trends. Scholars have tested the thesis, often in advanced capitalist contexts. In this article, I analyze the formation of modern penality and neoliberal influence in homelessness regulation in KL. My objectives are two-fold: 1) to consider the applicability of the punitive thesis to homelessness management in Malaysia’s capital, and 2) to consider how processes underpinning neoliberal outcomes in KL may inform transnational understanding of the "settled", or unsettled, nature of global and historical patterns in policy development.

As a former colony and Commonwealth country, Malaysia has inherited British forms of governance and customarily referred to UK practices. Overall, dominant politico-legal institutions and ideologies are analogous to British-derived systems elsewhere, the US included. Nevertheless, I argue that uncritically applying the concept of a "punitive turn" to Malaysia would be a mistake. Transnational trends in urban spatial orders cannot be understood apart from linkages to global and historical forces. This Malaysian case provides opportunity for urban scholarship on punitivism to operate "at a world scale” (J Robinson 2011:1) by considering city strategies beyond advanced EuroAmerican contexts. Specifically, I select KL for its historical and contemporary 
significance as a site for development of homelessness policy. Additionally, I offer through historical analysis a new frame for understanding the co-constitution of punitive and supportive dynamics under pre- and post-neoliberal reforms.

Homelessness Regulation, Policy Mobilities, and the Neoliberal Punitive Turn

The "turn” underscored in punitive turn discourse signifies deviation from a theorized late nineteenth century shift towards integrating rehabilitative ideals into penal policies. Garland (1985), in his genealogical account of crime control in the US and Britain, terms this concern for the welfare and reform of offenders as culminating in a hybrid "penal-welfare complex," lasting through the 1970s. He argues that whereas deterrence through punitive sanctions defined nineteenth century penal justice, penalwelfarism arose from "modern” ways of thinking about individuals and their relationship to society. Increasingly, state actors sought to rehabilitate offenders who were "to be pitied, cared for and, if possible, reclaimed” (1985:27) through scientific expertise.

Proponents of the punitive thesis reason that this inclusionary shift has been upturned by a neoliberal penality that, like its Victorian predecessor, embodies state power to enforce order through deterrence and punishment. Neoliberal faith in free markets and self-governance as solutions to poverty has absolved government from poverty management other than through security and policing. Hence, neoliberalism in advanced countries is associated with measures that "roll-back" supportive social programs and "roll-out” disciplinary institutional reforms (Peck and Tickell 2002), such as corrective social programs and enhanced policing of society’s “dispossessed, deviant, 
and dangerous” (Wacquant 2009:20). Often, such neoliberal outcomes are attributed to the influence of “made-in-the-USA ideologies and policies” (Wacquant 2001:405).

Policy mobilities literature highlights the transnational travel and translation of neoliberal policy. Scholars therein define neoliberalization as tied to retraction of Keynesian-welfarist institutions, inspiring transformation of "[this] geographically and historically specific form of statecraft...[into] new forms of statecraft " (Peck 2003:222; emphasis in original). The concept of "fast policy" underscores the speed and complexity characterizing contemporary policy travel. It seeks to correct notions of policy diffusion as smooth, unidirectional transfers and invites consideration of processes that select and modify policy over time. Study of fast policy mobilities highlights agents and processes that variously transform policy to produce its "local globalness" (McCann 2011) at each site. However, scholarly attention generally concentrates on neoliberal transformations pertaining to liberal-welfarist structures. How might one recognize neoliberal era policy beyond Euro-American-centered frames, particularly when most global cities fall outside such scope (Halperin 2015)?

Ananya Roy (Baker et al 2016) makes this point in questioning comparative policy studies that lack account of historical geographies of statecraft. Without a template of prior state forms and functions, she explains, one cannot fully gauge forces transforming governance. McCann (2011:109) similarly offers that "the circulation of policy knowledge is paradoxically structured by embedded institutional legacies and imperatives,” meaning that local agents and power structures markedly shape outcomes. Hence, understanding neoliberal transformation requires consideration of prior assemblages of governance to measure policy uptake on its own terms (Bunnell 2015). 
Scholars concerned with neoliberalism in homelessness regulation agree that exclusionary rhetoric and practice has transformed policy landscapes; however, debate surrounds whether recent punitive approaches should be unequivocally attributed to neoliberalism (Doherty et al. 2008; O’Sullivan 2012; Sylvestre 2013) and whether literature adequately accounts for inclusionary trends (DeVerteuil et al. 2009; Johnsen and Fitzpatrick 2010; Marr 2015). Such concerns are sound. The propensity to label homeless persons as threats to order, ostensibly necessitating their segregation and punishment, is well-documented in Western and Western-influenced policy (Adler 1989; Beier and Ocobock 2008). Furthermore, one cannot disregard ambivalence (Murphy 2009) bound into regulation, particularly where compassion and discipline intersect. Government agencies strategically cast anti-vagrancy crackdowns in KL as benevolent exercises of generosity, unapologetically slated for Ramadan. As DeVerteuil (2012) posits, the punitive relies on the supportive. Clear lines cannot be drawn between the two; rather, we ought to critically evaluate how they co-constitute and counterweigh each other.

Such scholarship underscores the importance of considering distinct socio-legal histories undergirding government and public thinking about homelessness, and how punitive and supportive strains shape regulation. These aims are parallel subsets of a larger concern: the need to account for the global and historical scope of regulation that defines homelessness and constructs terms for addressing it. Recently, O’Sullivan (2012) and Sylvestre (2013) have contended that contemporary responses to homelessness extend from historical treatment of vagrancy. O’Sullivan (88), while considering nineteenth and twentieth century Euro-American interventions, reasons that current 
punitive trends are tied to a continuation of "a core response to homelessness [that] was always punitive”. Additionally, he asserts that today’s "politics of social inclusion” are a more forceful driver of policy change. In response, Sylvestre acknowledges the same history yet refutes O’Sullivan's negation of neoliberal influence; instead, she (364) uses events in Canada as evidence that neoliberal ideas have instigated distinct punitive effects, owing to their power as "legitimating discourses to justify existing repressive practices” (original emphasis).

These perspectives raise important questions about transnational and transhistorical dynamics shaping homelessness regulation, and how situated agents respond to neoliberal pressures. As O’Sullivan suggests, neoliberal outcomes need not be imported or even explicitly pursued, but may derive from local agents and processes. Similarly, literatures on transnational policy networks (Stone 2008), global urban systems (King 1990; Knox 1995), and urban history (Home 1997; King 1976) illustrate that transnational networks—crafted from colonial and imperial urbanizations—-have long informed transnational urban imaginaries and distinct local histories. Hence, policy mobilities as a construct need not be limited to neoliberal-era policy diffusion but, rather, ought to include historical sets of inter-referencing practices exercised through global policymaking circuits (Bunnell 2015).

As Sylvestre's analysis concentrates on contemporary Canada and O’Sullivan's spans a broad swath of historical Europe, neither account traces data from a single site across time. Hence, I offer a transhistorical analysis of homelessness policy in KL to examine the "punitive turn” thesis, using Garland's genealogical approach and a concentration on vagrancy legislation. Elaboration of policy history is crucial for 
considering statecraft in locales, such as $\mathrm{KL}$, typically excluded from policy literature owing to their developmental status (J Robinson 2011). Moreover, it illuminates the circuits and effects of policy mobilities beyond those neoliberal (Bunnell 2015). Together, these facilitate critical interrogation into the neoliberal—or non-neoliberal— nature and roots of contemporary outcomes. Thus, I offer a response to calls by Bunnell (2015) and J Robinson (2011) for more comparative work across contexts, and by DeVerteuil (2012) for representation of interplays between punitive and supportive strands in homelessness policy outside the US.

\section{Historicizing Homelessness Regulation}

In Malay(si)a, KL has served as a key commercial and government center and a crucible for economic and urban development since the 1880s. Here, the scale of homelessness—and state attention to the same- - have regularly fluctuated with economic and developmental shifts. I present a historical analysis of transformations in antivagrancy regulation based on primary data from government and historical documents collected at Malaysia's National Archives, Singapore's National Archives, and the Singapore National Library. Archival records detail policy change over time, as well as underlying influences and debates. I obtained primary data on recent developments through interviews with officers responsible for enforcing and formulating policy at the Ministry of Women, Family, and Community Development. Last, I utilize secondary sources to locate legal and institutional developments within their socio-political and economic contexts. 
I take law and its implementing institutions as my unit of analysis; therefore, I do not trace changes outside the governmental sphere. In collecting data and conducting analysis, I identify how ideas are not only advanced by agents, but also transformed and embedded in codes and practices over time. Through a longitudinal analysis, I aim to highlight the history-laden context of contemporary plans to achieve "zero homeless" through care and control. I also adopt a global historical perspective as I trace ideational and institutional shifts in policy by situating them in the global field (Go 2008; Patil 2017).

Findings are organized into five historical periods, each containing ideological shifts shaping policy and practice. Since ideological and policy changes cannot be parsed into clear-cut chronologies, I introduce trends that pre-exist, persist, and overlap across categories. Nevertheless, each period highlights principal reforms in care and control. I adopt historically-accurate terminologies when referring to policy subjects, such as vagrants and beggars. While I see general use of such language as problematic, I employ it here to convey relevant socio-legal categories and historical forms of urban marginality. Also, I inflect history with recognition of "graduated citizenship", or differential treatment of diverse populations via state policy rooted in "market calculations and ethnic governmentality” (Ong 2006:79). Lastly, while I call attention to punitive and supportive measures in each era, my aim is not to classify them per twentyfirst century normative standards. Hence, although past supportive measures may appear punitive, I stress consideration of these policies as expressions of a particular geohistorical context. 
City Strategies and Policy Re/Formation in KL

1870s-1900s: Introducing vagrancy law

"Scrambles" for Africa and Asia followed the 1869 opening of the Suez Canal. This new state-led phase of global imperialism was fueled by aims to extend territorial control, manifested as Britain's Forward Movement in Malaya. Britain progressively expanded its political control beyond the Straits Settlements ${ }^{33}$ into the peninsula's interior, consolidated into the Federated Malay States (FMS) in 1895.

British Malaya’s politico-economic system—fashioned in the interests of British, Chinese, and Malay elites—guided homelessness regulation. Social Darwinism and racial thinking stimulated use of race as a strategy for cross-cultural negotiations (Manickam 2009) that produced and reified a hierarchy of ethnic identities: Europeans, Natives, and Migrants (Ooi 2003). Formal treaties established Malay rulers as symbolic heads of states and endowed British advisors with administrative control over the political economy. Government was predominantly British, while Chinese and British capital served as the economy's foundation.

Urbanization accelerated once KL became the capital of Selangor state in 1880, and the FMS capital in 1896. Growing commercial and manufacturing industries, regional development, and income from mining fueled transformation, all reliant on indentured and recruited labor from China, British India, and the Dutch East Indies. Sustaining this colonial economy required monumental in-migration, totaling 200,000500,000 persons annually by the 1900 s. Laborers, treated as expendable, were vulnerable

\footnotetext{
33 The crown's early mercantile ports.
} 
to illness, injury, exploitation, and homelessness. Many—especially Chinese laborers employed in mines surrounding KL—sought services or better prospects in the capital. In 1883, the government opened a Pauper Hospital in central KL. It received thousands of patients yearly, almost exclusively "coolies”, prompting its relocation to the outskirts in 1889. Government officers recognized high morbidity among coolie laborers as rooted in employer negligence and sought partial remedy through the 1895 Labour Code. Government also urged local Chinese elites to provide for their "population,” directing organized philanthropy into a central force in aid. KL's Chinese Capitan ${ }^{34}$ established the Tai Wah Institution and Fund to improve access to medical care for Chinese paupers. Located on Pauper Hospital grounds, the Institution provided housing for discharged patients, while the Fund subsidized carts for picking up sick and dying persons “from the roadsides” (Selangor Journal 1896:193-194).

Economic downturns also led to spikes in homelessness. In 1895-1896, “many labourers were thrown out of...the mines and...became vagrants” (Daniels 1906). Others became homeless after leaving employers to seek opportunity elsewhere. Hence, government officers recognized that hospitals alone were insufficient for reducing vagrancy. Yet, as visibility of "idle, “filthy”, “diseased”, and “weak” people in public grew (Hare 1897), so did pressure to “[rid] our towns of [this] most undesirable portion of our community” (Belfield 1904). Contemporaneously, in England, imaginaries of “vagabond savages” emerged from evolutionary and racial thinking that fused fears surrounding “itinerancy, class, criminality, race, and morality” (Hansen 2007:65). From

\footnotetext{
${ }^{34}$ Capitans were appointed Chinese leaders.
} 
this, greater scrutiny of “deserving” and "undeserving” characters (Haggard 2001) materialized in social policies and programs, including those brought by British colonialists to Malaya.

Vagrancy in KL became punishable by imprisonment in the $1880 \mathrm{~s}^{35}$. However, widespread illness among offenders spurred officers to allow admission to the Pauper Hospital's Vagrant Ward in lieu of jail (Welch 1894). Although the Vagrant Ward was built "as a Prison Ward...with iron bars," medical workers could not legally or logistically detain patients who were wont to leave (Residency Surgeon 1894). Thus, in 1893, Selangor adopted the 1872 Straits Settlements’ vagrancy ordinance mandating imprisonment for all vagrants, including those needing medical care (Daniels). Nonetheless, insufficient space in the prison hospital made policy impracticable. Advancing that neither hospitals nor prisons were adequate "for dealing with vagrants” (Hare), the government developed a new system for classifying and managing them. In 1902, the FMS enacted the Decrepit Vagrants Act, aimed at "provid[ing] for the control and relief of sick and decrepit vagrants.” The law stipulated that decrepit vagrants, defined as “medically certified...as physically incapable of earning a living," be held in special wards on prison premises. By this distinction, decrepit vagrants were legally absolved of wrong-doing, while able-bodied vagrants were subject to criminal treatment. However, both "classes” were confined to prison grounds.

Rules for Selangor's vagrant wards stipulated that "inmates are humanely treated, discipline is strictly enforced, and economy is duly promoted” (Selangor State 1902).

\footnotetext{
${ }^{35}$ I have arrest records, but not an exact statute. Arrests may have occurred without legal basis (Residency Surgeon, 1894).
} 
These norms sprung from customary notions that "Government [should not] support vagrants in idleness” ("Vagrancy Bill” 1906) and vagrants, including decrepits, would benefit from labor (Hare). Perak’s Resident enthused, “[C]onfinement in the ward is [not] merely a punishment but also a means of enabling the vagrant to recover his health and become a useful [community] member” (Belfield 1904). He then urged that decrepit vagrants in wards receive longer sentences than the able-bodied in jails.

1910s-1930s: Refuge and repatriation

In the early twentieth century, global political-economic integration amplified individual vulnerability to international markets and facilitated the spread of sociopolitical mobilizations. In response, imperial states increasingly turned to interventionism and the provision of social protections to quell unrest and enhance legitimacy at home and abroad (Bayly 2004). British Malaya gained prominence in the global market as accelerated production of tin and rubber elevated its commercial importance. Its political order remained fragmented with supreme power vested in Malay rulers, economic power in Chinese and British capitalists, and the Colonial Office overseeing each. The scale and demographics of homelessness in KL shifted with development and the economy, such as upsurges in Indian vagrants during rubber market slumps.

At the century’s turn, white homeless “beachcombers”-often European sailors and American soldiers - pervaded Asian port cities. Fear that they might "lower the standard of the orang-puteh (white people)” (Vagrancy Bill 1906) in colonies quickly manifested in policy such as the Straits Settlements’1906 Vagrancy Ordinance, which included statutes to expedite repatriation. This law, lauded for purging the "disgrace” of 
"poor Whites" and deterring "vagrant classes of Chinese [who] fear banishment...more than imprisonment” (“Vagrancy Bill”), soon shaped FMS regulation.

FMS officers used repatriation to tamp down vagrancy even before its incorporation into vagrancy law. As early as 1891, the Prisons Department advocated solving the "intolerable nuisance" of vagrants through repatriation (Hare). Some Chinese vagrants were repatriated via the 1899 Banishment Enactment. Additionally, government regularized and funded extra-legal repatriations, particularly during the 1910s.

Nonetheless, the FMS streamlined repatriation through its 1921 Vagrancy Enactment, modeled after the Straits Settlements' Ordinance, enabling commitment of both decrepit and able-bodied vagrants to vagrant wards for up to one year "until work has been found...or until he is [repatriated]”. Government records show decrepit workers frequently resisted repatriation, spurring some officers and civic leaders to defend their right to remain.

Concurrently, multiple agencies sought to establish a Central Decrepit Asylum. They aimed to support key mining districts by removing "vagrants knocking about” and offering "laborers [suffering from] ware and tare" (Choo 1925) "a decent home and refuge....in accordance with modern notions” (Dowden 1927). The 1928 Vagrants and Decrepit Persons Enactment and its 1934 successor passed in this spirit. The laws redefined decrepits and vagrants as "two classes" deserving "differential treatment" (Rigby 1933), namely, rehabilitation for decrepits and punishment for the able-bodied, both subject to repatriation unless employed in one year. Decrepits were sent to “settlements," inspired by European labor colonies and managed under the High Commissioner and Medical Department. The largest, located outside KL in Sungai 
Buloh, opened in 1934 for Chinese laborers. Debate continued over forced repatriation, as few migrants wished to return. Eventually, the asylum was abandoned. Instead, officials granted settlement land to a neighboring leprosarium and dispersed inmates throughout FMS hospitals (Fitzgerald 1934).

1940s-1960s: Preserving public order through compulsory care

World War Two played a powerful role in unsettling empire globally. For one, Japan dislodged Euro-American rule throughout Southeast Asia. Afterwards, colonialists returned to their former colonies, the British with plans to reconstruct empire. However, nationalist and anti-imperialist movements persisted, eventually leading to decolonization. In Malaya, ethnic tensions and a communist insurgency prompted the British to declare a state of emergency (1948-1960) complicating plans for a centralized multi-ethnic state. Between 1948 and 1957, native-born and long-term residents of all ethnicities were gradually conferred citizenship. The federal government, embracing economic fundamentalism, undertook development plans that channeled investments into "productive” economic sectors while avoiding "consumptive”, "non-remunerative” liabilities of social services (Ness 1967:107; Rudner 1972:65). Mass rural-urban migration and urban extension fueled population growth in KL, now the federal capital, exacerbating underemployment and housing insecurity.

Policies for managing destitution were modified for different aims under Japanese rule (1941-1945), not explored here. After their postwar return, the British reorganized government agencies, authorities, and legislation at all levels, resulting in a substantial shift in homelessness management. In 1948, the newly-formed Social Welfare 
Department (SWD) was given jurisdiction over pauper hospitals and decrepits. As it planned unified federal legislation, the SWD coordinated repatriation of "destitutes and other persons” (David 1950). Simultaneously, large numbers of "unfortunate old men, many [who served Malaya] in their youth” were filling prisons, causing the Prisons Commissioner (1946) to protest with "great embarrassment" at having to incarcerate them like criminals.

By the mid-1950s, anxiety rose over a perceived begging epidemic in the capital. The SWD conducted a nationwide survey of 750 beggars, finding that three-quarters were Chinese and concluding that the problem for all ethnic groups lay in "elderly folk being pushed...into the ranks of the unwanted” (SWD 1955:16). The report also debunked “popular myths about beggars” like lucrative earnings. However, such considerations were not reflected in policy. Instead, federal agencies pursued legislation for “deterrence and punishment” (SWD 1955:1), realized through statutes in the 1955 Minor Offenses Ordinance that expedited arrest of "idle and disorderly persons". The report (1) concedes that most beggars had disabilities, but government homes were full and "demands for drastic economy" made expansion impossible; thus, penalization seemed the most expedient route.

In 1957, federal agencies formed a Committee to "rid the streets of Kuala Lumpur of beggars” prior to independence celebrations (Elliott 1957). Teams of police and social welfare officers conducted raids publicized as “Operation Beggar”. In 1958, social welfare officers discussed using Mersing Camp in Johor, 200 miles from KL, as a multistate detention facility (Raja Abdul 1958). The Municipal Secretary urged immediate action to "remove the scar...of beggars...leav[ing] a bad impression on...foreign 
visitors” (Mohamed Din 1961). In response, the Prisons Commissioner (1961) insisted that, "prison is NOT the place for beggars and vagrants.” The Social Welfare Ministry (n.d.) agreed, calling incarceration “incompatible with social justice and human rights”. Thus, alternate means were necessary.

Malaya’s first federal vagrancy law was drafted over 1961-1964. The Act endowed police with powers to arrest "destitute persons” and have them “compulsorily detained” (Fiennes 1962) at social welfare facilities. The parliamentary counsel assumed the arduous task of drafting legislation that decriminalized begging and vagrancy, yet justified arrest and detention for the same. This was achieved by defining such acts as offenses against public order, enabling circumvention of constitutional protection of movement. The bill also presented detention as a mode of care delivered in “rehabilitation centers”. Parliament passed the Vagrants Act “for the care and rehabilitation of destitutes and the control of vagrancy” in 1964. Police enforced the law in periodic raids, and the Ministry opened Desa Bina Diri (DBD), its federal rehabilitation center, in Mersing.

1970s-1980s: Policing as social welfare services

The 1970s world crisis transformed economic globalization, as shifts to off-shore production prompted global restructuring. This essentially underwrote the "East Asian miracle” and the rise of Southeast Asia’s newly industrializing economies. Many Asian states moved to control quick-paced industrialization and urban change by intervening in development processes. Additionally, swelling Southeast Asian tourism inspired states to take appearances seriously. Malaysia was no exception in any case. 
In Malaysia, postwar development exacerbated socio-economic disparities and political discontent, culminating in an ethnic riot in 1969. Thereafter, political leaders used inter-ethnic tension to justify “soft authoritarian” rule (Khoo and Loh 2002:4) and garnered favor by elevating poverty eradication as a national objective via the New Economic Policy (NEP). However, NEP focus on rural sectors meant that urban poverty received little attention, despite growing pressure on the capital as manufacturing drew migrants from Malaysia and abroad. Simultaneously, KL’s escalating importance—after its cession from Selangor and establishment as Malaysia's first federal territory-fostered concentrated development (Bunnell 2002) and federal desire to control the city.

Between 1965-1970, police caught over 2,500 people nationwide in anti-vagrancy raids and the Social Welfare Ministry launched a Three-Year Plan to "eliminate” (menghapuskan) beggars nationally. In KL, police formed the Beggar Eradication Committee (Jawatan Kuasa Membasmi Pengemis) to coordinate apprehension of migrating (berhijrah) beggars and their "sentencing” (menghukum) to rehabilitation centers (Lim 1970). In 1973, the Social Welfare Minister was asked in Parliament whether government would aid "these people... as [poverty eradication] is the policy of the Alliance Government” (Dewan Rakyat 1973). She responded that vagrancy and poverty were separate matters, rebuffing that aid was necessary. However, government publicly presented raids and arrests as "benefit[ing]” and "protect[ing]” subjects, thereby more closely aligning policy to care (Hartog 1972:218).

In 1975, the Ministry’s research division produced an unpublished internal report urging “greater understanding and compassion” for beggars and vagrants (Welfare Services Ministry 1975). In a nationwide survey, it found that beggars were "[not] an idle 
shiftless lot...[and generally had] honest employment well into old age”. Authors noted that most were foreign-born, often with Malaysian citizenship but no family, and half were former rubber estate, tin mining, or manual laborers. Moreover, they (110) criticized the "evolving" system by which people must reach absolute destitution to access state assistance and urged consideration of "a right to protection and care”, especially for “dependent ageing person[s]”.

The next iteration of vagrancy legislation brought little substantive but radical procedural change. Enacted in 1977, the Destitute Persons Act transferred powers of arrest from police to social welfare officers ${ }^{36}$. Hence, the social welfare ministry attained legal mandate over the regime, from coordination of raids to arrests and rehabilitation centers. Vagrancy legislation became social welfare policy: further removed from its penal origins in theory but largely identical in practice.

Officers conducted over 1,000 raids nationally between 1977-1979, averaging five weekly in KL in 1979 (Begging Bares 1979). In 1981, an investigative newspaper report on DBD decried the practice of indefinite detention saying, "many become mad over time...[or] stay until they die” (Dregs 1981). This prompted a 1985 amendment limiting detention. The explanatory statement conceded that indefinite detention was "longer than necessary" and caused "emotional disturbance [that] could adversely affect rehabilitation programme[s].” (Act A638 1986)

\footnotetext{
${ }^{36}$ Also, officers appointed by local authorities.
} 
1990s-2016: Criminalization as care

Through the 1990s, Southeast Asia remained a key site for the transnationalization of production, and swelling migration and capital flows. While the 1997 Financial Crisis served as impetus for neoliberal structural reform throughout the region, it also kindled popular mobilization and protests against the hegemonic powers of US and international institutions. In Malaysia, Prime Minister Mahathir advanced neoliberal tendencies towards furthering privatization, liberalization, and deregulation as he tightened authoritarian rule. He also made KL a symbol and vanguard site for Malaysia’s global future by further interweaving it into global and regional politicaleconomic circuits.

Malaysia had minimal "big government” infrastructure for paring down, but neoliberal principles discouraged expansion of social protections through the bogeyman of the welfare state. Near double-digit GDP growth through 1997 fueled optimism and dampened tension brought by rising drug addiction, pressure on low-income households, and swelling numbers of foreign workers. The late 1990s reformasi movement mainstreamed social protest and paved new avenues for civic dissent. As Mahathir's successors ascended in 2003 and 2009, popular support for Malaysia's ruling party waned and protests grew, spurring authoritarian backlash and new strategies for retaining power.

In the 1990s, Mahathir sought to make KL a "world-class” city though heightened urban development, directing multiple mega-projects and a new limelight to the capital. This intensified colonially-rooted aversions to "dirt, disorder, and underdevelopment” (Bunnell 2004:299) and fostered policies for removing the urban poor. Federal agencies 
expanded anti-vagrancy sweeps using vagrancy law statutes to form multi-agency operations (operasi bersepadu); thereafter, Immigration and the newly-established National Anti-Drug Agency, among others, became regular partners in enforcement. Hence, while welfare officers could only provide "rescue" by sending arrestees to rehabilitation centres, other agencies could investigate and charge vagrancy offenders for crimes. Homelessness was presented as a menace to Malaysia's economy and dignity, as when the social welfare minister proclaimed tourists must "not see these people making a nuisance of themselves [so we] round them up and put them in rehabilitation centres.” (Minister orders 1996)

The Ministry of Women, Family, and Community Development began bolstering anti-vagrancy infrastructure in the 2000s by building four new DBD centers, more than doubling capacity. It also sought to extend protections and powers for enforcing officers in a 2008 bill (DR18/2008), later withdrawn. Ministry data show persons taken into custody rising between 2000-2009. Concurrently, the Ministry took steps to engage civil society, noting growing grassroots involvement in homelessness outreach. In 2010, it collaborated with NGOs in a KL street count. The following year, Prime Minister Najib announced he would direct federal funds to a pilot shelter. Nevertheless, federal agencies unfurled deterrence measures like the KL campaign, "Henti Memberi, Kami Prihatin (Not Giving is Caring)” designed to educate the public that almsgiving fuels addiction and anti-social behavior.

The Ministry’s plans to criminalize begging, announced in April 2014, involved neither criminal legislation nor police. Rather, Minister Rohani explained, vagrancy law would be amended to make begging “an offense” because current provisions included 
only avenues to rehabilitation centers and "no element of punishment” (Nurbaiti). Since begging remains a punishable offense under the 1955 Minor Offenses Act, the Ministry was proposing the creation and management of a new offense governed through its own powers. While this announcement elicited little response, plans revealed in June prompted greater scrutiny.

That summer, public protest erupted following statements by Minister Rohani and the Federal Territories Minister. The former promised an escalation of anti-vagrancy raids in KL for Ramadan, and the latter introduced plans for metropolitan bylaws criminalizing almsgiving and food distribution. Ramadan's significance as a charitable season, and restrictions on civil liberties affecting the public writ large, sparked tumult. Civic organizations vowed to disobey municipal bans, and unflagging media attention to the controversy inspired both agencies to reverse rhetoric and undo plans within days. Minister Rohani insisted publicly that raids were "rescues”, while proposed bylaws were abandoned. The Ministry proceeded with smaller-scale sweeps throughout KL during Ramadan, spurring opposition politicians and NGOs to call for vagrancy law’s repeal. Eventually, the Prime Minister, Minister Rohani, and the Federal Territories Minister sought to regain public trust by visiting NGOs. Within days, Prime Minister Najib promised a new shelter.

In 2016, the Federal Territories Ministry and a property developer collaboratively launched the Homeless Transit Center in KL, currently administered by a governmentlinked NGO. Rohani’s Ministry is formalizing a new stance that supportive homelessness programs be managed by civil society and lower government tiers; thus, it urges action from state and local governments and NGOs. Simultaneously, it continues to enforce 
vagrancy law with 1,500 persons caught nationwide in 2015, and plans expansion of its “rescue and rehabilitation” regime.

The Trajectory of Vagrancy Law

Here, I answer my queries about whether KL's homelessness regulation is undergoing a “punitive turn”, and what these events could tell us about the "settled”, or unsettled, nature of historical patterns in policy development. I examine KL’s policy trajectory vis-à-vis its global relationality and territorial particularities. Together, these denote Malay(si)a’s regulatory paradigm. I conclude with lessons from history.

Global relationality

Just as cities are “relationally (re)constituted [through] 'citation, allusion, aspiration, comparison, and competition"” (Bunnell 2015:1984), the arc of changes in laws and institutions applied to KL from the 1880s has been distinctly shaped by translocal references. Management in late nineteenth century KL began with arrests and imprisonment, reflecting practice in early US-UK penal regimes. While philanthropic organizations offered aid, agencies in KL increasingly reoriented engagement with vagrancy as a social rather than criminal justice concern, analogous to contemporaneous penal-welfarist approaches. Such change is illustrated in treatment of decrepit vagrants, who emerge as an exceptional category differentiable from the able-bodied. Their difference was formalized in law, and later prompted creation of management strategies such as facilities for “relief” and "refuge,” derived partly from European systems. 
From here, a penal-welfarist fusion took place in vagrancy institutions, redesigned according to Western-influenced “modern notions” prescribing state intervention. State institutions sought to segregate and repatriate vagrants when providing for welfare, based partly on Singaporean precedent. In the 1960s, rehabilitation centers became central institutions for "care and rehabilitation" consistent with globally-prevailing ideas of the protective duty of welfare agencies. By 1977, the regime was entirely recast under the social welfare ministry's jurisdiction. Over this course, punitive and supportive aims were married in myriad ways. Policy objectives counterbalanced early aims of control with "care and rehabilitation,” while enforcement incorporated both policing and (compulsory) care. Thus, penal-welfarism emerged in forms that reflected British origins by simultaneously drawing from and perpetuating binaristic classification of people as pitiable or dangerous. Nonetheless, policy perceptibly stressed care over punishment. Policy developments from the 1990s also reflect relational influences. For one, the expansion of anti-vagrancy raids to target drug users and undocumented immigrants, among others, mirrors "broken windows” policing. In the 2000s, the social welfare ministry doubled its capacity to detain destitute persons via newly-built "rehabilitation" facilities. Such neoliberal transformations were achieved through extension of existing domestic institutions and infrastructure. Additionally, since 2010, state initiatives for care have been increasingly devolved to local government and civic and private actors. In Malaysia, as elsewhere, such changes are not driven solely by government since civic and private sector actors vie for state sanctioning to manage care. Together, these transformations mark a recalibrated orientation in state anti-vagrancy regimes: whereas 
agencies foregrounded care in the 1960s and 1970s, by the late 1990s they used demands for increased "security" to justify enhanced policing and forced removal.

Territorial particularities

While globally-travelling ideas shaped homelessness regulation, territorial particularities reveal that their adoption did not mean wholesale accession to "imported" frameworks. Rather, local factors had a decisive effect on outcomes. For instance, when public officers advocated for long-term refuge for decrepits, demands for economy nevertheless lead to systematic repatriation. Similarly, rights and justice sworn to vagrants in the 1960s relieved prisons of having to incarcerate them, but did not prevent government from sidestepping their constitutional protections. Moreover, recent government calls for enhanced deterrence and punishment have spurred no "turn" to police involvement. In each case, globally-mobile ideas were reformatted to fit local circumstances, ideologies, and institutions.

Relative to Euro-American developments, Malaysia’s (post-)colonial context uniquely shaped policy interventions. For one, demographically, most unsheltered persons in colonial KL were Chinese and South Asian laborers who existed at the intersection of three marginal positions: as "sojourners" at the bottom of class and ethnic hierarchies. Their disposability, manifested in processes leading to vulnerability to homelessness lasting into the 1970s, shaped institutionalization of homelessness policy. As repatriation became a leading strategy, the scale by which people were expelled from the city meant that homelessness management became less a matter of social engineering, aimed at reintegrating persons into national life, and more of segregation of non- 
productive workers and citizens. The "civilization" achieved through this rationalization was an exclusionary one, consistent with KL's colonial ethos.

Similarly, whereas emerging social protections shaped penal-welfare complexes in post-imperial countries, the absence of such protections shaped Malay(si)a's. For instance, police remained the lead agency responding to homelessness until 1977, and in 1965 the social welfare ministry undertook responsibility for care only after vagrancy arrests. From 1977, in the absence of a welfare state, or universal rights to protection and care, the welfare ministry took on a distinctive role by serving as arbiter of policing and detention vis-a-vis the Destitute Persons Act. This “rescue and rehabilitation” regime, bolstered by abundant substructures for "control” and "care," led to Malaysia's twentyfirst century approach to homelessness criminalization: through social welfare initiatives. This "punitive turn" does not appear as a "startling reversal of a settled historical pattern" (Garland 2001). Instead, it resembles a continuation.

Although impulses for care were occasionally stymied or abandoned, care should not be construed as the weaker force. Care, like punishment, was repeatedly proposed, opposed, subverted, and renewed in negotiations that shaped management. Notably, its influence was channeled through Malay(si)a’s (post)colonial constraints; agencies governed in accordance with raced, classed, and otherwise hierarchically-ordered imperatives. In response to resistance by vagrants to detention and repatriation, some civic and government figures adopted more stringent practices (e.g. "iron bars") to ensure state care, while others challenged the cruel nature of the same. Criticism of overlycoercive care, coupled with demands for more genuine protection, proliferates in nineteenth and twentieth century historical records. Multiple agents in and beyond 
government continually (re)assessed these imperatives, making care and punishment alike driving forces in policy.

Today, too, the force of multiple agents and events bears down on vagrancy regulation. Public protest halted the adoption of new criminalizing measures. Yet, federal agencies remain reluctant to repeal vagrancy law, which is central to historicallyentrenched logics justifying removal of "destitute persons" and the material substructures for doing so. Policy change would require realignment of each and, as public pressure remains marginal, little impetus for change exists. Moreover, neoliberal ideas reinforce state aversion to social assistance by absolving government of social responsibility. As before, engagement with globally-circulating ideas inspires policy transformation, but changes are channeled through local logics and imperatives.

A Malay(si)an paradigm of homelessness regulation

In Malaysian vagrancy law, care and penality have historically functioned as two sides of the coin of control. As in Europe, they variously intertwine with imaginaries of the deserving and undeserving poor, defined by who is "fit to work". However, in practice, punitive and supportive aims have been fluid and nearly transposable. In the late nineteenth century, for instance, forced labor and confinement were prescribed as curative measures for "sickly" and "sturdy" vagrants alike. This obscure terrain between supposedly clear-cut policy categories illustrates the ambivalence bound up in regulation: of knowing and not knowing the problem, of wanting and not wanting to help. As the colonial government navigated penal and social reform, it fused deterrence strategies of 
banishment and imprisonment with benevolent strategies of care to produce a succession of hybrid institutions like vagrant wards, decrepit settlements, and rehabilitation centers.

In post-independence Malaysia, rhetoric surrounding implementation of vagrancy law has been both disciplinarian and compassionate. Mass round-ups and raids, albeit contrary to constitutional rights, have been presented as a win-win response that delivers an orderly city while providing compassionate "rescues" to those in need. Thus, it discursively becomes practical and ethically palatable as policy. However, within the dichotomous framework of deterring the dangerous and rescuing the pitiable hides a paternalistic parlor trick: namely, the will and wishes of persons experiencing homelessness is rendered irrelevant. Once one qualifies as a "destitute person,” only the state is deemed capable of making decisions affecting one's life. Such a view of “destitute persons” opens a Pandora’s box of violations; it reasons that an individual's best interests are served by suspending their civil rights.

This alienation of the rights and interests of persons experiencing homelessness rests at the core of vagrancy law. The doctrine of parens patriae, derived from English common law, confers the state with power to act as guardian for individuals regarded as incompetent or otherwise incapable of making decisions (Stauts 2000). Consequently, legal systems, welfare practice, and public attitudes in many Western and Westerninfluenced societies assign persons "in need” with a different "bundle of rights” (Failer 2002). Vagrancy laws historically rendered people experiencing homelessness secondclass citizens via parens patriae, essentially denying them "full personhood" (Feldman 2004). The logic of this control, amalgamated from seemingly opposed-yet-intertwined tendencies for compassion and repulsion, is shared among multiple countries in the 
global North and South. Such connectedness may facilitate transnational circulation of strategies that amplify globally- and historically-entrenched imperatives of punishment and care. The danger to persons experiencing homelessness and, by extension, our collective ability to prevent or reduce homelessness lies not in punishment or care but in the overarching frame of legal paternalism that merges these. Overcoming such a danger requires an alternate frame: one that does not harm the rights, undermine the human securities, and obscure the voices, knowledge, and interests of persons experiencing homelessness. Decisions that are forced upon unsheltered persons, founded on convictions of their incapacity, are instruments of control—and a barrier to constructively addressing homelessness.

O’Sullivan (88) notes that “a core response to homelessness was always punitive.” Supportive aims, too, consistently drove responses. While politics of inclusion and imperatives of care are essential for developing and enacting policies to improve individual and collective security, history shows that they will not necessarily lead to the same. Inclusion not set on the terms of persons experiencing homelessness risks prolonging difficulty and exacerbating harm as it may channel paternalistic drives to “care and control”. Care must be enacted outside of paternalistic frames.

\section{Conclusion}

Recently proposed measures suggest that globally-mobile policies carried neoliberal, or "punitive turn," trends into Malaysian homelessness regulation. However, closer examination reveals that pre-existing ideologies, institutions, and pressures were also activated as pillars for reform. That is, change emerged from both relational and 
structural contingencies: while federal proposals signaled references to neoliberal strategies elsewhere, they were also built from historically-established logics and practices. This pattern has surfaced for over a century. Historically, cross-border flows of policy ideas — channeled, challenged, and transformed through interface with variouslysituated agents—-have generated KL’s particular trajectory of regulation.

In Malaysia, shifts under neoliberalization indicate that, as before, locally-situated politics of punishment and care variously drive change in homelessness policy. Simultaneously, punitive and supportive state practices have upheld principles of parens patriae, undermining basic rights. Such principles embrace caring, yet raise grave questions about the nature and legacies of paternalistic care. Why would rights and protections be null once one is “destitute”? Does "rehabilitation” address the interests of persons experiencing homelessness? Public and civic actors have long posed such questions, stimulating continual resistance and change.

Comparison of change across developmental contexts reveals that neoliberalization in homelessness regulation need not revolve around "rolling back" state social programs, which may be sparse in global South countries. Nevertheless, my account shows that the Malaysian neoliberal state "rolls out” disciplinarian restructuring alongside disavowals of responsibility for care. Important here is that (post-)colonial states historically consigned care to family, community, and non-government sectors, and this enduring practice is now (re-)emerging in (post-)imperial states. This affirms Halperin’s (2015) claim that neoliberalization deploys practices once “submerged” (70) by Keynesian-welfarism in the global North, such that "post-Keynesian spatial policies...[resurrect] pre-Keynesian structures” (90). Greater study may show that this 
disavowal of the "social state" has led to intensification of anti-vagrancy codes and parens patriate doctrine in homelessness regulation globally. While these were "submerged" in the global North by welfare state interventions that reduced homelessness, they nonetheless persisted—as evidenced by Britain's 1824 Vagrancy Act, still in force, and US substitution of vagrancy law with criminalization and coercive care.

This longitudinal account illustrates history's bearing on the neoliberalization of homelessness management, as mediated through contemporary ideational and institutional foundations in policy. Tracing the local re/formation of regulatory regimes over time facilitates identification of globally- and locally-rooted factors in policy changes. Additionally, this study shines a light on the prominent role of historical policy mobilities in not only shaping policy re/formation at the city scale, but also underpinning the transnational construction of policy fields, such as homelessness management. The global historical dissemination and propagation of vagrancy laws facilitated development of divergent city strategies for homelessness management that, with greater study, ought to evidence shared imperatives of care and control.

Across other policy fields, too, long histories of cross-border policy travels have produced global constellations of comparable policy regimes. These contemporary regimes—albeit mutually distinct—necessarily incorporate logics and institutions that potentially resonate across borders. The synergies that exist between policy approaches enacted by regimes that are differently-located yet historically-entangled likely direct and reinforce policy trends at multiple scales. That is, in KL as elsewhere, it is precisely because globally-mobile neoliberal ideas activate nodes of illiberal rule historicallyembedded in local policy that agents may select them as "legitimating discourses to 
justify existing repressive practices” (Sylvestre). Hence, examining neoliberalism’s global reach requires understanding, through global historical studies, how contemporary governance structures, policy regimes, and inter-referencing strategies have evolved. 
CHAPTER 3. NEOLIBERALISM'S IMPERIAL PAST

THE JANUS FACE OF ANTI-HOMELESS URBANISM AND TOKYO’S MODERN SOCIO-SPATIAL DEVELOPMENT

Introduction

The 1995 Tokyo metropolitan government report, “A New Urban Problem and Future Responses” marks a turning point in public and government thinking around homelessness in Japan. Historically, homelessness was characterized as a matter of "idle” “vagrants” lacking stable employment or accommodation, as defined in a century of antivagrancy codes. However, regulatory attention shifted in the 1990s to "homeless persons” engaging in "inappropriate use” of public space. In its 150-page report, the Metropolitan Policy Planning Office (1995:64) underscored detrimental effects of homelessness on "the health and well-being of urban society" and advocated action to ensure “[everyone] including homeless persons can live like human beings". This view underlay Japan’s first national policy on homelessness, enacted in 2002, which newly defined "homeless persons" as people living in public space.

In 1996, tensions felt by government regarding urban redevelopment and swelling recessionary homelessness led to actions that heightened public scrutiny. Notably, metropolitan agencies evicted one large encampment in Shinjuku Station’s West Exit corridor while arguing that construction of a \$3-million walkway required it. Agencies prepared accommodations for evictees but most encampment residents refused to leave prompting a stand-off and intense media attention (Hasegawa 2006). News reports 
highlighted divergent public views: some identified camps as unwelcome and supported clearance, while others voiced dismay regarding copious investment in walkways over welfare. Ultimately, the clash fueled movements that brought greater civic involvement and rights protections into policy.

These tensions birthed Japan's first national policy, designed to manage the twin interests of bolstering "self-reliance” and ensuring "appropriate use” of public facilities under welfare and urban development agencies, respectively. Metropolitan- and localgovernment agencies also replicated this dual-focus structure fusing social and spatial remedies in subsequent measures involving housing-first initiatives, public work programs, and public assistance, each offset by enhanced securitization of public space (Kitagawa 2010). These policies have had distinct socio-spatial effects, as users are directed to facilities and districts that historically accommodated housing-insecure populations. Additionally, people who find no refuge in the current system face mounting prohibitions against using tents, benches, and public facilities essential for their survival.

Abundant literature on neoliberalization details these socio-spatial effects, marked by the production of “certain kinds of spaces” (Mitchell 1997:304) for reintegrating or relocating people (Peck 2001). Moreover, Sparks (2012:1512) finds historicallyentrenched ideas of "homeless deviance and dependence work alongside and through" neoliberal policies in a "mutually constitutive" relationship with spatial management and social citizenship, as evidenced elsewhere (Feldman 2004; Gowan 2010; Lyon-Callo 2004) including for Japan (Hayashi 2015; Marr 2015). However, historical inquiry into homelessness regulation in Global North contexts rarely extends prior to welfare states, thus averting the "traumatic mid-twentieth century" (DeVerteuil 2012:875) of 
imperialistic militarism and genocidal violence; therefore, why prior ideas would be symbiotically attached to neoliberal-era policy is left to speculation. Here, I ask: exactly how are past ideas bound up in responses to homelessness, spatial management, and social citizenship?

In this chapter, I argue that historically-entrenched ideas concerning homelessness are produced from—and essential to—imperial formations (Stoler 2008), defined as asymmetrical relations of power that, in homelessness regulation, propagate dual-focus regimes of care and control governing “disorderly” peoples and spaces. In a review of policy history, I illustrate how public agencies have variously merged corrective and compassionate logics and practices when crafting interventions, and how these responses simultaneously distract from — and reinforce-a nullification of the right-full existence of persons experiencing homelessness. I argue that this systemic delegitimization of homeless existence via policy lies at the root of anti-homeless urbanisms, and not the supportive, punitive, or ambivalent ambitions thereby conveyed.

Why the Imperial Past?

Increasingly, scholarship explores what is old rather than new about neoliberal transformations. This multidisciplinary literature builds on postcolonial studies of imperial-colonial relations and their lasting effects in fields like urbanization (King 1976), social science (Blaut 1970), and economic development (Rodney 1973). Today, scholars extend postcolonial theory into "cosmopolitan" methodologies that decolonize Eurocentric and nation-state-centric paradigms by “globalizing” social (Go 2016) and spatial (J Robinson 2011) inquiry. This involves “thinking across” different experiences 
and allowing for pluralities (J Robinson 2011:2), rather than adopting essentialist, hierarchical constructs. Such cosmopolitan approaches facilitate identification of “webbed connectivities” (Patil 2017) across time and space that reveal the globalhistorical roots of contemporary political-economic systems, including relations of domination (Stoler 2006; Narayan 1995) and other legacies of empire (Halperin 2015).

Colonial and capitalist expansion have been justified through ideas of racial difference since feudal Europe (C Robinson 1983). By Japan’s Meiji era (1868-1912), Western imperialist powers traded mercantilism for liberal ideology, prompting states to pursue wealth by governing individuals (rather than markets) in what Foucault (1980, 2008) calls a society of normalization intent on suppressing abnormalities. Nineteenth century Lockean thought spurred litmus tests of liberal citizenship, barring inclusion to people deemed incapable of reason like children, persons of insufficient "breeding” or “inheritance”, and colonial subjects (Mehta 1999:59). Thereafter, ideas and institutions borne from the liberal codification of hierarchical relations and the Eurocentric legal ordering of people (Benton 2016) proliferated in policy systems globally owing to EuroAmerican imperialist expansion. Concurrently, Meiji leaders navigated the global order by emulating and challenging dominant Eurocentric models (Hane 2016) in an autocolonial mode of Westernization (Komori 2004) that produced Euro-normative yet distinctly Japanese policy systems.

In Japan, industrial capitalist development began with dispossession of socially marginalized groups from their customary lands, particularly those believed to fall outside of Japan's civilizational boundaries. This had a lasting impact on communities considered external to: national polity, like Koreans and Ryukyuans; Japanese culture, 
like indigenous Ainu people; and the pre-Meiji social order like outcaste burakumin (Hane 2016; Howell 2003). Consequently, from the late nineteenth century, urban zones formed in Tokyo where these and other impoverished and uprooted people were spatially contained (Dohi 1994). During Taishō (1912-1926), yoseba (day labor) districts emerged from these zones where people grappling with socio-economic insecurity found casual employment and accommodation, including sons and daughters shed from rural households under male primogeniture systems (Aoki 1989; Fowler 1996). Hence, yoseba “turned vagrants into laborers” (Takenaka 1969), though labor and housing insecurity meant yoseba also intrinsically produced homelessness (Eguchi 1979).

In Japan (Bayliss 2013; Soejima 2014) and globally (Beier and Ocobock 2008), nineteenth century homelessness regulation was exemplified by vagrancy law and the ambiguous legal category of vagrants, while twentieth century management introduced welfarist strategies producing "a hybrid penal-welfare structure” used for rehabilitation (Garland 2001:28). As neoliberalization in the Global North has advanced the roll-back of twentieth century social protections and roll-out of new disciplinary interventions (Peck 2001), historically-entrenched "tropes of homeless deviance and dependence” have bolstered an otherization of homeless existence that delegitimates claims to social citizenship (Sparks 2012:1512-1514). In Japan, decades of deindustrialization, welfare reforms, deregulation, and urban redevelopment have produced similar outcomes, disproportionately impacting persons experiencing homelessness and yoseba neighborhoods characterized as “dark” and deviant (Haraguchi 2016; Hasegawa 2006; Hayashi 2015). For instance, recent policies direct attention to people “dependent” on public space via policy narratives that downplay welfare-state principles of universality 
and state responsibility, while advocating neoliberal tenets of self-reliance and publicprivate partnerships (Sasanuma 2008; Kitagawa 2010; Marr 2015; Yamada 2008).

Growing attention to gentrification (Haraguchi 2016), anti-homeless securitization, and their effects of reducing "tolerant space" (Murota 2017) has stirred Japanese scholarly interest in Smith’s (1996) revanchist theory, owing to its unwavering critique of profiteering urbanisms, increasingly state-led, that defend displacement in furtherance of redevelopment. Revanchist theory and related literatures underscore exclusionary forces advanced by neoliberal socio-spatial regulation as state interests shift from "underwrit[ing] social reproduction" in cities (Smith 2002) to "penal treatment of urban marginality” (Wacquant 2009:21). However, controversy surrounding revanchist discourse and its “dystopian” and "singularly punitive” tenor, has motivated scholars to pursue more “sympathetic” critiques of neoliberal shifts (DeVerteuil 2012:875). Such scholarship elucidates “more complex, and more varied” (DeVerteuil et al 2009:655) arrays of responses spun from not only punitive but "kinder and gentler” (Murphy 2009:323) aims. A "shifting constellation of policies and practices" (Greene 2014:320) constituting a "blurry geography" of hybrid practices has emerged to include “compassionate revanchism” (Hennigan and Speer 2018), “coercive care” (Johnsen and Fitzpatrick 2010), and “therapeutic policing” (Stuart 2016).

Lawton (2018), borrowing from this scholarship on hybridity, offers that today's revanchist city has a double: "the seductive city", which reshapes gentrifying processes by incorporating promises of justice and diversity. Such dualisms and hybridities not only blur the neoliberal present, but also saturate our modern global past, as underscored in postcolonial literature on colonial-imperial relations (e.g. Bhabha 1994). Therein, social 
control through law has hinged on punitive and therapeutic responses (Black 1993) that pervade Euro-American “harsh relief practices” (Piven and Cloward 1993:177). Indeed, welfarism itself was established in metropoles by European reformists who mimicked nineteenth century colonial civilizing missions, epitomized by Salvation Army’s projects in “darkest” London (McLaughlin 2000). Hence, policy histories reveal care’s “dark side” of paternalistic tendencies (F Robinson 2016) that "sometimes function ideologically to justify or conceal relationships of domination” (Narayan 1995:135). However, in homelessness regulation, continuities across nineteenth, twentieth, and twenty-first century policy regimes remain largely unexplored.

As DeVerteuil (2012:880) notes, this gap derives partly from academic silences surrounding "the traumatic mid-twentieth century” of war and genocidal violence, leading to the demise of the imperial world order. These silences limit our ability to interrogate modern governance because they hide "basic political contradictions of nation-states [as seen in] gaps between the political freedoms implied and the political limits experienced” and their ramifications under neoliberalism today (Kelly and Kaplan 2004:140). Such silences reinforce still-unexamined narratives that postwar policy regimes established by imperialist states are structurally more compassionate or just than their predecessors. By extension, divorcing the postwar global order from its past also risks inferences that neoliberal configurations and complexities are wholly unique. As Halperin (2015: 69) notes, recent changes in state forms and political-economic governance are far from "historically unprecedented”.

While DeVerteuil (2012:879) is correct to dispute “singularly punitive” narratives of neoliberalism, his argument against “pessimistic” discourses urges a "historical 
appreciation” that optimistically adopts a singular view of mid-twentieth century genocidal violence as "intentional” and incomparable to today's "sort of non-intentional structural violence”. I offer this not to single out DeVerteuil but underscore how hegemonic narratives and silences that selectively put various pasts to rest insulate particular histories from examination. The imperialist past and neoliberal present are neither the same nor entirely separable. However, defending human life, rights, and securities requires knowing the ties and divides between them.

Tracing Imperial Formations (1868-2019) -Research and Writing-

This chapter draws on archival materials collected to identify "legacies of empire" (Halperin 2015) and “imperial formations” (Stoler 2008) in modern homelessness regulation spanning criminal justice, welfare, and urban development policies. Primary sources included policy documents, agency reports, and social survey data procured from the National Archives, National Diet Library, Tokyo Metropolitan Archives, and public information disclosure systems.

Because government records and archival resources emerge from ambiguous processes and power relations that "[contain, obscure, or deny] certain historical truth" (Trundle and Kaplonski 2011:409), I adopt Stoler's (2009) critical approach to qualitative content. I read materials both with and against the grain to appreciate and scrutinize documented claims in an archival ethnography centered on recovering the experiences and voices of subjects. For analysis, I adopt Fingfeld-Connett's (2014) methodology for systematic review, including processes of coding data, memoing, diagramming, and 
reflection. I identified regulatory systems by first selecting and sorting data on pertinent institutions, laws, and practices and then conceptualizing policy structures. Last, I used historical process-tracing to examine key mechanisms in and outcomes of interventions across public agencies.

This history merges with Foucault’s population geographies (Legg 2005), or the advent of modern population regulation through classification systems and penal-welfare structures (Garland 2001). Therein, social policies cultivated biopolitical divides between insured and non-insured lives to realize socio-spatial control (Duffield 2008). Because I focus on street homelessness, and have limited space, I do not detail the myriad rehabilitative and custodial institutions produced by social policy for people deemed “deserving” of protection like women, children, and people with disabilities. However, in reviewing history, I include signposts to indicate how these institutions emerged as mechanisms for reinforcing a social and spatial order necessarily premised on raced, gendered, abled, and classed capitalist divisions of labor. As this paternalistic policy framework re/defined "deservingness" of aid over time, street homelessness—and urban zones like yoseba districts—became spaces for cultivating and enforcing "self-reliance" among those excluded. Consequently, this chapter narrates how imperial formations, or uneven relations of power, in policy and practice across the twentieth century led to disproportionate homelessness among outwardly able-bodied men. Likewise, I highlight how policy frameworks prolong and capitalize on homelessness, including through yoseba, as an institution for these unprotected "labor-capable men". 
In doing so, I adopt the following terminologies:

- Labor-capable - refers to people deemed suited to labor in the discretion of policy agents, considering age, mental and physical condition, etc.

- Men - refers to people deemed men in the discretion of policy agents.

- Vagrants, sick travelers, beggars - are specific policy terminologies. I use these terms only where they illuminate popularized policy categories.

As outlined earlier, marginalized groups have historically been over-represented in yoseba populations. Although I do not detail these histories, I urge readers to remember that "labor-capable" has been globally and historically aligned not only with gendered (male) bodies but also with raced and classed ones (Roberts and Mahtani 2010) owing to locally-situated ideas of who is more suited to casual labor and enforced/coerced "self-reliance”.

I divide Japan's modern history into five epochs of socio-spatial re/development encompassing: early Meiji (1868-1899), early twentieth century (1900-1929), wartime (1930-1945), postwar (1945-1979) and neoliberal (1980-2019) eras. Trends introduced pre-exist, persist, and overlap across periods. Nevertheless, each represents a key stage of institutional and ideological development, discussed further in subsequent sections. By this history, I demonstrate how state control over spaces and people, realized through Janus-faced arrays of compassionate and corrective interventions, rely upon the delegitimization of homeless existence. I argue that this delegitimization, a legacy borne from imperialism, is the heart of the imperial formation. 
Imperial beginnings: Status containment to spatial containment (1868-1899)

Homelessness today is perhaps regarded as a problem experienced by people rather than of people, but historically this was not so. For centuries, European antivagrancy codes created a legal truth of homelessness as an anomaly. As the globalizing imperialist order engaged Japan in the mid- to late-nineteenth century, people without stable employment or abode were deemed spiritually and materially “savage” and anathema to enlightened modernity. Meiji-era leaders understood that the world's great powers would not recognize Japan as an autonomous civilized state unless its people and urban landscapes exhibited such spiritual and material—social and spatial—development.

The Meiji Restoration, or Japan’s transition to a renewed imperial state, was largely guided by bureaucrats trained in Western studies. Hence, the Meiji mission of “rich nation, strong army” brought Western-influenced capitalist development and empire-building, primarily achieved by merging Western and Japanese institutions. Western powers imposed some policy changes through unequal treaties like Westernstyle penal codes. Other changes, like the abolition of caste, emerged under less explicit pressure. As Japan’s modernization untethered people from feudal orders and stimulated new territorial claims and expansion, outcaste burakumin, Ainu, Ryukyuan, Taiwanese, Korean, and other subjects disproportionately endured dispossession and impoverishment owing to displacement from social economies under imperial systems.

Japan’s feudal caste systems had allocated social roles to vagrants, but Western models of regulation required their removal from public space. Japan’s Justice Ministry ordered Tokyo’s first clearance in 1872 prior to a Russian diplomatic visit to avert 
"weakened public security and national shame” associated with homelessness (Dohi 1994:57). Police detained hundreds, later transferred to a new poorhouse. Able-bodied poorhouse residents were subsequently conscripted to urban development projects advanced by the Home Ministry, rebuilding the very spaces they were driven from (Dohi 1994).

From the 1880s, penal and welfare programming more closely reflected structures and logics of Western liberal capitalist systems. Japan’s first penal code (1880) criminalized vagrancy, defined as lacking stable abode or employment. Vagrants were presented as criminals who "disturb and intimidate others [and] yearn for unlawful property...[harming] both public and private” (Yokairei 1892). Rights advocates challenged anti-vagrancy measures, but authorities argued that "vagrants' activities obstruct human freedom [so they] earned their fate.” (Yokairei 1892) Reinstituting public order—previously organized though caste systems—required relinking subjects to community and state through allegiance to the modern economy, measured according to labor. Hence, anti-vagrancy codes became crucial instruments for interrogating individual relations to the political-economic system.

Early Meiji welfare policies offered limited material aid. Sick Travelers Assistance Regulations (1871) authorized police to pick up people incapacitated along roads and public spaces, sending those without homes to the poorhouse. Relief Regulations (1874) obliged communities—not the state—-to care for the poor, but offered rations to non-labor-capable persons lacking caretakers. Home Ministry officials insisted that Japan, unlike Europe, must offer only sparse relief to prevent any "loss of independent spirit” (Akaishi 1982:315) but encouraged private-sector actors to help the 
needy. Philanthropist Shibuzawa Eiichi modeled this altruism by taking charge of Tokyo’s poorhouse, eventually limited to sick travelers. Vagrancy statutes were used to arrest outwardly healthy people vilified in media reportage as "maggots”, known to live along district borders and evade police by crossing jurisdictions (Tokyo’s Maggots 1891). In the late 1880s, urban development involved spatial segregation of lower-class communities, presumed to carry contagion. Segregation included: bans on kichinyado (cheap lodgings) in Tokyo, excepting peripheral zones like Asakusa and Ueno, alongside laws authorizing police surveillance of kichinyado occupants. Studies on homelessness described vagrants as comprising societies with people of various ages, genders, and (dis)abilities. One 1896 survey of ragpickers found 95\% stayed near kichinyado in Asakusa and Ueno. Poorhouse records show sick travelers were predominantly workingage adults found in kichinyado districts where employment brokers clustered (Muzenshi 1903). Overall, police occupied the frontlines of homelessness regulation as they monitored kichinyado, rescued sick travelers, and arrested vagrants—all in districts formed by law to facilitate surveillance by containing poverty.

The private realm made public: "Improving social infrastructure and inner life" (19001929)

Imperialist expansion and laissez-faire capitalism cohered the globalizing order. Japan adopted a coordinated market economy and German-influenced paternalism in social policies. Western powers recognized Japan's constitutionally limited democratic government as evidence of its modern, autonomous status and dissolved the unequal 
treaties by 1899. Moreover, Japan’s 1905 victory in the Russo-Japanese War rendered it a "great power” globally, which bolstered domestic support for the imperial state.

Increasingly, people viewed themselves in relation to the world. Qualifying exams for civil servants required proficiency in international law and European languages. Policymakers and practitioners regularly referred to foreign sources and attended international conferences on law and development. Mass media, too, connected people to the world such as by reporting on vagrancy abroad.

Public investment in social infrastructure accelerated after the 1900 enactment of Kanka (Reform) Law, inspired by Protestant movements in Europe and Japan. Reformist ideology was instrumental in spiritually binding subjects to industrial capitalist society as it limited liberty to "self-governing” individuals_-defined as people imbued with virtues like industry, sobriety, and self-help. Conversely, poverty was treated as evidence of virtue’s absence-either through willful deviance or blameless incapacity. Hence, by law, poverty undercut claims to liberty. Poor people deemed unable or unwilling to work, like sick travelers or delinquents, were obliged to enter rehabilitative or reformatory institutions. Labor-capable persons could only claim autonomy if they pursued employment; hence, reformists opened employment services, typically specialized according to gender, nationality (i.e. Japanese, Korean), and class.

Japanese reformist movements adopted European colonialist rhetoric, as seen in publication of In Darkest Tokyo (1894), modeled after William Booth’s book In Darkest England, depicting the "dark" nature of lower-class neighborhoods and the "light” of virtuous labor. Japanese researchers launched surveys, including Tokyo’s earliest on beggars (1909) and vagrants (1910), while political leaders, scholars, philanthropists and 
industrialists began collaborating on reform agendas "to prevent [poverty] and provide aid where it already exists” (Hiro-Chusa 1913:1). Persons associated with homelessness were portrayed as existing on a spectrum from pitiable to dangerous, all adjacent to criminality. Muzenshi (1903:6) noted, "vagrant youth start earning through begging and later...become pickpockets and muggers...before finally becoming habitual criminals and sick travelers.” Tropes specific to women also emerged, especially as gendered labor divisions (i.e. male breadwinners, dependent housewives) became widely accepted in the 1920s. These featured women or girls who start begging or sex work, contract disease, and then turn to exploiting children and joining organized crime (Sechiyama 2013). Hence, social interventions were intended to forestall or end criminality by assisting people based on their ability and will to work and nurturing self-governance. Shibuzawa himself endorsed labor-based solutions, highlighting reduced prison expenses and increased productivity as benefits.

Gendered labor-market segmentation and its relation to homelessness was clear by Meiji's overwhelmingly female first industrial workforce in the 1900s. Because young women were expected to work only provisionally and remain virgins until married, they were subject to lower (non-breadwinner) wages, severely restricted mobility (i.e. dormitories, curfews), and greater job insecurity relative to male counterparts. Shelters and employment services mushroomed around kichinyado. Surveys showed that Asakusa's employment brokerages served mostly women seeking factory and domestic work, yet homelessness predominantly affected men as unemployed women were either rehoused by marriage or lost to trafficking (Kitaura 1913). Increasingly, public agencies centered male experiences of homelessness, often treating women as corrupting factors 
(Sake and women 1926), while expanding both criminalization of sex work and women's assistance programs.

Labor division also shaped urban spatial development, as seen in heightened incorporation of productive (e.g. industrial) and reproductive (e.g. residential) zones and infrastructure in city planning. This birthed yoseba districts as, in the 1920s, Tokyo's newly-founded Social Affairs Bureau invested 500,000 yen (USD\$23 million today) in lodging houses, followed by public markets, cafeterias, and bathhouses to support the reproductive routines of labor-capable men and extend their workforce participation. Officials stressed that material aid would ensure laborers could subsist on dismal wages. Hence, laborers remained poor, and anyone worse off presumably had only themselves to blame.

Recurring crises over the 1910s and 1920s introduced social unrest. Public agencies expanded social programs in response, but refused economic aid lest it create dependency and corrupt "beautiful Japanese traditions of family and community support" (Yasui 1933:77). City government introduced the Homen-Iin system, a volunteer network that infused state authority into everyday lives (Garon 1998) and sought to reduce poverty through inculcating industriousness and conservative values. Inclusionary state programming targeting the working classes_-including universal male suffrage in 1925 — grew with industrialization, especially since imperial growth relied on workingclass labor. Correspondingly, marginalized groups leveraged their productive value in social movements to gain state protections.

Public commitment to welfare led to improved social infrastructure (setsubi), but practitioners prioritized shaping and improving subjects' inner life (seimei) above all else 
(Yamamuro 1925). Diaries of labor-capable men staying at free shelters detail their anxieties—most related to socio-economic factors compelling them to work (Tokyo Social Bureau 1928). This includes verbal abuse by workplace supervisors, discriminatory public attitudes, and distress caused by just the possibility of missing workdays due to weather, illness, abure (being sent away), or need for rest. Diarists articulated problems posed by day labor and proposed solutions like new forms of social assistance, rectification of inequalities, and avenues to steady work, underscoring that policy and prejudices mandating industriousness exacerbated, rather than resolved, hardship.

Welfare as empire’s burden (1930-1945)

Japan faced a financial crisis in 1927 and the global depression in 1930. Together, these revived public skepticism regarding capitalist modernization. As one day-laborer noted, modernization brought convenience like electricity, but also generated "despair and suicide” (Tokyo Social Bureau 1928:64) After the 1931 Manchurian Incident and subsequent military takeover, public agencies abandoned economic liberalism and individualist dogma. Japan instead pursued a centrally-managed "co-prosperity” economy geared towards territorial expansion and mass mobilization, justifying greater micro-level interventions. From here, social policy priorities shifted because, as Japan’s Welfare Council (1956:80) acknowledged, "helping the weak and needy was overshadowed by [concerns] for securing human resources and [expanding] production capacity.” 
The 1929 Public Assistance Act, partly "borne from Western ideas and legacies" (Yasui 1933:3), redefined welfare. Like its predecessor, the Act barred labor-capable adults from assistance. However, it newly obliged the state to provide aid, mediated by state-appointed Homen-Iin agents. Homelessness fell beyond the scope of direct assistance, but state agencies expanded shelters for protected categories of people like youth and single mothers, while offering new accommodations and work programs to labor-capable men. Accordingly, Homen-Iin escorted people to police, employment services, and shelters as necessary. They also visited yoseba to urge laborers to abstain from vice and send remittances home.

In the early 1930s homelessness and unemployment skyrocketed. The Social Affairs Bureau acknowledged that anti-vagrancy roundups were ineffective, given circumstances, and launched new shelter and public work programs. While easing roundups, Tokyo’s Police Superintendent-General visited facilities with reporters in tow to meet “overjoyed” residents (Maruyama’s Visits 1930). However, within months, agencies resumed a critical tone. City government identified vagrants as the capital's "cancer" and "shame”, and justified plans for clearance by pointing to available support (Clearing Asakusa 1931:1205). New repertoires emerged supplementing care with clearance, and vice versa, to seemingly offer subjects a choice between carrots or sticks: assisted integration or banned, degraded existence. For instance, police began distributing lodging tickets and material aid while advising (rather than coercing) vagrants to leave. Similarly, by 1935, men staying in Tokyo's free shelters were being sent to work in Manchurian colonies—by welfare officers. 
The Social Affairs Bureau endorsed public welfare as vital for industrial growth and emblematic of an enlightened national family. The wartime magazine, Manchuria Graph, reinforced this message in one story about a Japanese resident in Shanghai who gives food daily to an elderly Chinese beggar (Sanada 1940). One winter day, he wakes from a fever to find the beggar dead, frozen in his waiting spot. This allegory for benevolent care, commitment to community and empire, and arguably the impossibility of supporting dependent populations concludes with the protagonist's despair for failing the man. Yet, unlike empire's imaginary of its own benevolence, people marked as vagrants felt isolated and scorned. For instance, one diarist bemoans: "Just because we stay at [free shelters] does not mean we are any different as human beings; I don’t understand why society treats us like beggars” (Tokyo Social Bureau 1928:61)

Compassionate and corrective repertoires featured prominently in imperial policies because they explained state interventions—and, hence, relations of domination—in the language and limited democratic systems of liberty, marking what Foucault (2008) calls the democratization of sovereignty. The mandated order-despite claims of generosity—required people like the beggar and shelter residents to remain in precarity, because of imperialist anxieties surrounding dependence, especially where manifested in men. Sociologist Koto Eichi (1933:171) explores what he terms "loneliness" among people without stable abode, suggesting it emanates from both social denial of their humanity and political denial of their rights. His analysis underscores their historical unbelonging — of being granted aid but not full personhood by paternalistic Janus-faced interventions. 
Making then insulating the universal state: discretion, self-reliance, devolution (19451979)

Firebombing and Japan's Fifteen Years War left Tokyo in shambles. The postwar Allied occupation (1945-1952) guided democratization by indirect rule: GHQ/SCAP oversaw policy development while Japanese agencies independently instituted systems. All actors referred to new international models in setting standards, like the Beveridge Report. Specifically, social policy under the Welfare Ministry was deemed fundamental to realizing a stable, democratic society.

Postwar social insurance systems, like their prewar counterparts, were stratified and paternalistically-predicated on male-breadwinner models. Still, there was a conspicuous ideological shift away from reformist “uplift” towards universalist egalitarianism. Japan's Livelihood Protection Act (1946) obliged government to provide aid "without favor or discrimination"; however, one statute contravened this by denying eligibility to persons "lacking will to work". While 1950 revisions eliminated the statute, they also introduced the objectives of "guarantee[ing] basic living standards and promot[ing] self-support”. Hence, the specter of idle vagrants continued to haunt welfare policy.

Tokyo’s population exploded as war survivors and returnees rushed in, many homeless. Tokyo reportedly held three-quarters of Japan's unemployed and Ueno remained synonymous with homelessness. Government agencies renewed imperial-era institutions like roundups, shelters, vagrancy laws, and yoseba districts and reorganized them into systems that distributed aid unevenly, with "true” vagrants granted the least. Police, railroad management, and municipal welfare officers quickly launched roundups 
under GHQ guidance and rehoused thousands in makeshift shelters, albeit without legal basis (Iwata 1992). Agencies classified people in custody according to perceived need, relegating "true vagrants" to the poorest quality accommodations and aid (Iwata 1995). People with any strength typically escaped these shelters, as conditions were better outdoors. Concurrently, city government erected tents in Tokyo’s yoseba, Sanya, where people avoiding shelters or seeking work would go.

A self-organized union of people sleeping in Ueno Station challenged stigma and isolation by posting flyers in 1948 declaring, "To all women and men, young and old... who are penniless... come build a bright and joyous family with us" and take "pride that we are outstanding Japanese citizens, not vagrants” (Otani 1948:146). Yet, Tokyo’s landscape changed as postwar reconstruction progressed. After anti-vagrancy statutes were reintroduced in 1948, police used arrests to drive people into Sanya until it began drawing people naturally in the mid-1950s as a laborers' town. Sanya’s population peaked at 15,000 in 1962, and pre-Olympics construction boosted employment among younger laborers. However, repressive policing, continued from prewar governance, produced tensions that escalated after installation of Japan's second-largest police outpost, dubbed "The Mammoth”. Periodic riots erupted in response to police mistreatment and inaction over labor exploitation. Central and municipal agencies launched Sanya Taisaku (Measures) in 1960, intended to enhance economic security among residents via employment services and work programs, with limited social services for families.

American influence in welfare policy reinforced prewar concerns for dependency and inaugurated casework and discretionary decision-making as pivotal mechanisms for 
staving off moral hazards. Manuals instructed caseworkers to "[fix] problems beyond those addressed by Livelihood Protection” (Japan College 1960:359) such as failure to understand "industriousness and productivity deliver one from poverty" (Furusawa 1955:42). Although livelihood protection was both universal and a constitutional right, welfare offices launched welfare corrections (fukushi teiseika) in the mid-1950s designed to cut recipient benefits and, by extension, ensure "self-reliance" and reduced expenditure (Japan College 1960). Additionally, protocol (until 2003) barred persons lacking stable housing from receiving aid; instead caseworkers directed them to welfare homes that advocated "becoming self-reliant and leaving” (Shinagawa 1955). Moreover, supportive facilities like these deliberately incorporated penalties, like discomfort, to discourage extended use (Akiba 1959). By 1956, sociologist Isomura Eiichi observed that Sanya’s day-laboring residents were "outside the scope of modern welfare" and targeted for scrutiny not despite, but because they lacked secure housing, family, and employment (Iwata 1992:21).

Before the 1964 Olympics, Japan began promoting Tokyo as a "welfare city", highlighting its constitutional guarantees to basic living standards as evidence of its advanced status. This, however, heightened anxiety around homelessness. Citywide clearances targeting tents appeased some, while sweeps conducted by police and welfare officers dispersed rough sleepers. Welfare-city strategies also prompted administrative restructuring (1963-1967), bringing social infrastructure under lower, ward-level management and homelessness-related policies under multiple levels of governance, diffusing authority. With this greater discretionary power, ward offices used sweeps (renamed "street consultations”) and “extra-legal support” measures (i.e. aid outside 
Livelihood Protection, such as emergency rations or transportation fare) to shuttle people between districts and pack them into Sanya (Iwata 1995). Local welfare and police officers swept the city, acting jointly as protectors and enforcers, to direct labor-capable men to Sanya while mobilizing welfare-state resources for protected categories of persons, such as women, children, and the elderly or ill. Welfare officers also worked with psychiatric facilities to direct Sanya's rough-sleepers into voluntary and involuntary commitment.

Over this span, city planners classified Sanya a slum using racialized US definitions concentrating on broken families, blight, and minority enclaves. This affirmed public views of Sanya—already known for its violence, vice, single parents, unregistered children, and proximity to Korean and burakumin neighborhoods—as menacing. Men unable to find work relied on selling blood, such that many fainted and died in the streets. However, this symptom of poverty too was held against them as evidence of an ingrained lazy, shameless, or degenerate character. Quickly, Tokyo launched slum clearance campaigns to relocate married and single-parent households from Sanya's "dark" neighborhoods to nearby wards deemed more appropriate for women and children. By 1970, only unattached labor-capable men remained.

In the 1970s, metropolitan agencies recognized Sanya’s deepening poverty as linked to population ageing and diminished employment but persisted with status-quo solutions: stop-gap labor programs. Despite knowing that employment programs were ineffective in addressing poverty among ageing laborers, authorities declined to act beyond existing paradigms, instead doubling down on self-reliance. As homelessness spread across Tokyo, central and metropolitan development agencies launched small- 
scale clearances around roads and public infrastructure, all while installing fenceenclosures to prevent re/entry. Tokyo Councilor Hosaka Sanzo publicly said that homelessness policy was in a detestable state-particularly in Sanya—citing institutional failures to act regarding public suffering and death. The Sanya Taisaku Office (1976:1) warned that Sanya’s once-renowned “dynamism” had become "stagnant” and asked: "What will become of Sanya’s laborers?”

Turning the public realm private (1980-2019)

Japan’s bubble economy brought record-level affluence co-existing with mounting homelessness. In 1980, a day laborer—mistakenly reported as homeless—set a bus on fire in Shinjuku, killing many. In response, local governments starting with Shinjuku began organizing so-called "environmental cleanup” committees to lead patrols for removing vagrants.

Tokyo’s 1995 report emerged from pressures posed by climbing homelessness, predominantly among labor-capable men over 50, alongside stalled redevelopment in Shinjuku. Metropolitan agencies planned to convert available Sanya Taisaku infrastructure into a centrally-managed city-wide shelter system. However, the televised spectacle of aggressive evictions in 1996 spurred public debate surrounding homelessness, evictions, and human rights. Through 2002, cases carried to the supreme court also elevated related concerns. Hence, government fused ideas from its 1995 report with rights-based frameworks to produce new national policy in 2002.

The 2002 Homeless Self-reliance Support Act established protocol for interventions targeting "homeless persons," defined as people living in parks and public 
facilities. First, the Act explicitly frames homelessness as a constitutional rights violation, obliging action by the Ministry of Health, Labor, and Welfare (MHLW) to "bolster selfsupport” among homeless persons, which affirms only the second aim of Livelihood Protection ("guarantee[ing] basic living standards and promot[ing] self-support”). Funding was channeled to MHLW for outreach services (25\%), temporary shelter accommodation (10\%), and employment services (33\%) to guide people to labor markets. These measures are classified as extra-legal support (hōgai-enjo) because they fall outside of and cannot be used with Livelihood Protection. Second, the Act authorizes public facilities to "ensure appropriate use...wherever occupation by homeless persons hinders this”, overseen by the Ministry of Land, Infrastructure, Transport and Tourism (MLIT).

Over 10,000 people entered the self-support system in its first years, but few from Tokyo’s encampments. Hence, metropolitan agencies launched the 2004 Transition-toCommunity-Life Program, targeting tents in metropolitan parks. Two metropolitan bureaus oversaw the 2004 Program: Social Welfare managed recurring park patrols and voluntary rehousing into subsidized apartments while Construction managed park security to prevent re/settlement and "inappropriate use" of public space. Early on, civic groups and tent residents questioned program terms, including limited two-year contracts to subsidized housing and ineligibility for Livelihood Protection. Nevertheless, the program initially proceeded unmodified, forcing tent residents to choose between subsidized apartments or tents, each potentially untenable in the long term. Within two years, tents declined by half—and in ten years, by $90 \%$. Additionally, post-911 and postearthquake (2011) security concerns became pretext for so-called upgrades in smaller 
parks involving enclosures, privatization, and anti-homeless architecture, further shrinking access to public space.

In 2008, the grassroots Haken-mura campaign brought attention to a mushrooming demographic of young, contingent workers facing homelessness, borne from late 1990s deregulation. Public shock at the co-existence of poverty and employment, particularly among youth, led to public support for correcting discretionary practices that denied Livelihood Protection to labor-capable men. Also, despite the yoseba’s post-industrial decline, government agencies modified policies to bring more people into Sanya. For instance, in the early 2000s, Sanya Taisaku public works programs—once limited to day laborers—began accepting people without day-labor experience. Similarly, Livelihood Protection—once denied to anyone in doya (SRO) accommodation—became accessible in 2003.

Today, metropolitan agencies promote revitalization of urban parks, dubbed "the face of Tokyo”, particularly in Ueno, Shibuya, and Shinjuku (Ishikawa 2007). Recent projects include Shibuya’s New Miyashita Park, a mall-top park modeled after New York City’s High Line and entrusted to Mitsui Fudosan for development. Metropolitan departments also have plans for a new soccer stadium in Shibuya's Yoyogi Park. These projects are preceded and accompanied by evictions and securitization, alongside new housing-first programs under Shibuya governance. Securitization has hinged on prohibitions against tents and other settlements enforced by patrols for ending “inappropriate use” of public space. These modes of control targeting "homeless persons" and complicating their survival is meant to incentivize entry into expanding welfare 
programs. In fact, metropolitan agencies expect uptake of housing-first programs in all twenty-three wards by 2020 .

Neoliberal policies have extended pre-neoliberal strategies of channeling laborcapable men away from universal welfare protections towards stopgap aid and selfreliance programming, albeit via new and more structured fusions of clearance and care. Moreover, while policies include innovations like rights protections and supportive housing schemes, socio-spatial impacts remain unchanged. Anti-homeless securitization proceeds apace, and unsheltered persons are directed to Sanya through revised welfare and public works programs. Yet, government agencies have failed to address historicallyrecurring structural exclusions that fundamentally undercut the efficacy of aid.

Yamada (2008) illustrates this in an analysis of government data showing that Livelihood Protection, or universal aid, performs as well as homelessness-specific "selfreliance” programs in supporting exits from homelessness. Moreover, he shows it would be more effective if not for drop-out rates largely attributable to conditions imposed on people applying while homeless. That is, because regulations prohibit anyone in a state of homelessness from receiving aid, people who are in fact homeless must enter registered medical or residential facilities for accommodation, where aid is conditional on their stay. Yamada reveals that state reliance on these ad hoc spaces—often run by non-profit and private-sector actors—-positively correlates with drop-out rates. In reality, state reliance on these spaces negatively correlates with its ability to adequately support clients inside.

These ad hoc, state-mandated institutions exist not because certain people lack stable homes, but because people experiencing homelessness—historically and today— 
are legally treated as lacking self-governance. This lack ostensibly justifies imposing limitations on their autonomy, including restricting constitutional rights to aid (granted in Japan’s Article 25). Moreover, these facilities necessarily complicate exits from homelessness because, by extending state powers and paternalistic relationships of authority over "homeless persons", they embody unilateral and undemocratic systems of rule over users, dictating their interests and needs, at best, and rendering them vulnerable to abuse and exploitation, at worst.

These spaces have long been essential to the imperial purposes of homelessness regulation, which requires unilaterally correcting the anomaly of homelessness. That is, the legacy of vagrancy law, and the corpus of the imperial formation, rests in policy systems and processes that nullify the right-full existence of people experiencing homelessness as a platform for myriad punitive, supportive, and ambivalent interventions that, furthermore, engender spaces that continue to suspend or diminish rights for the sake of rehabilitation. The Janus-faced nature of regulation functions to validate the necessarily undemocratic delegitimization of homelessness within myriad policy fields. Moreover, this delegitimization, a vessel for relations of domination, obstructs society's only avenue to effectively addressing homelessness: by the knowledge and guidance of people with first-hand experience.

Policy's configuration complicates users' channels for voice and exit, resulting in chronic failure to serve their needs or interests. For instance, regulation is complicit by its inaction in widespread political disenfranchisement, whether due to a lack of address or other conditions hindering political engagement. Additionally, because people experiencing homelessness are systematically excluded from the democratic public, they 
have few avenues for holding public service providers to account. This insulation of public and state-mandated service providers from direct accountability discourages policy users faced with program failures or hazards from exercising voice; instead, they have acquiescence or exit (i.e. street homelessness), where exit is delegitimized by its unlawful/unprotected status. These conditions produced through policy compel users to endure insecurities and indignities such as medicalization (Lyon-Callo 2004) and abuse, or choose unprotected existence (Kitagawa 2010). While homelessness carries innumerable risks, it is nonetheless preferable for many who—-through no fault of their own—find no refuge in the present system. Given the intolerance directed through law and society towards people marked by abnormalities (Foucault 2008), including but not limited to homelessness, some people find open space the most tolerant (Murota 2017).

Neoliberalism’s Imperial Past—and Present

The modern configuration of regulation—-merging punitive, supportive, and ambivalent technologies atop delegitimized existence—-is not accidental. It extends from imperial projects of socio-spatial development founded on asymmetrical relations of power. Social policy and programs developed as instruments atop anti-vagrancy bans, not as alternatives but enhancements. Consequently, prohibitions over time-such as against vagrancy, receiving Livelihood Protection while unsheltered, and "inappropriate use" of public space—-have preserved a socio-legal illegitimacy of homeless existence constraining access to rights and protections. Fundamentally, it is unlawful status, rather than corrective or compassionate action per se, that is weaponized to compel conformity. 
Arrays of punitive and supportive intents offset rudimentary prohibitions to render people hyper-visible as pitiable, contemptible, or otherwise in need of rehabilitation and reintegration (Foucault 2008; Feldman 2004), justifying intervention. Hence, Janus-faced ambitions perfect the modern configuration of regulation as they direct attention to problems created by law, i.e. illegitimate existence, or failing to "live like human beings" (Koto 1933), thereby cloaking the role of law itself, as interventions are contested and reshaped. This socio-legal entanglement, introduced as Agamben’s (1998) Homo Sacer and eloquently applied to homelessness by Feldman (2004), ensnares people targeted by policy—and pervades the temporal and spatial breadth of modern homelessness regulation.

Responses developed atop delegitimization of homelessness necessarily fail policy users and society because of how they normalize and propagate forces of domination like paternalism and violence, which multiply anti-homeless sentiments and spaces across micro-, meso-, and macro-level geographies. Effects include exploitative and abusive practices long-plaguing shelter, employment, and other supportive services (Kitaura 1913; Yamada 2016) and the persistence of policies of questionable efficacy, like Sanya Taisaku, still active today. By its present configuration, homelessness regulation cannot produce humane or adequately responsive solutions because it fundamentally identifies homeless existence as the primary problem, conflating it with “disturb[ance of]...both public and private” (Yokairei 1892), or socio-spatial disorder, necessitating pretexts for engagement and spaces for containment above all else. Stated differently, regulation is schematically-designed to unilaterally correct interruptions of an imperial imaginary and actually-non-existing socio-spatial order. Its construction serves 
only the ideals and whims of power by authorizing public agents to act unilaterally while absolving them of accountability. Most tellingly, this configuration—produced from powers of domination—deprives people experiencing homelessness of legitimate avenues to caring for themselves on their own terms.

By focusing on continuities from the imperial past to the neoliberal present, I do not mean to imply that recent decades of change are unimportant. To the contrary, they connote political and economic currents driving governance itself. For instance, neoliberal-era insistence on redefining homelessness vis-a-vis urban space underscores a definitive shift in public-sector priorities: from maximizing industrial productivity to expanding commercial development through public assets and surplus life (Willse 2015). Policy landscapes suggest that public agencies were attuned to shifting capitalist logics since the 1960s, evident in the fusion of slum clearance and private development, policy stasis vis-a-vis Sanya's escalating poverty, and mounting urban securitization ${ }^{37}$. Today, policies involve trifectas of evictions, accommodation programs, and large-scale re/development like New Miyashita Park, each hinging on public-sector coordination and private- and voluntary-sector implementation. While agencies increasingly embrace innovative supportive programs and protections, aggressive state sanctioning of and investment in measures tackling "inappropriate use" of open space suggests that a "new urbanism” (Smith 2002) and neoliberal financialization, rather than welfarist interest, underpins enduring political will to address "homeless people".

${ }^{37}$ For US-based discussion, see Weber (2002) 
Because Tokyo’s "blurry geography”-marked by “caring means of control” and "spaces of care... bolster[ing] anti-homeless urban geographies” (Hennigan and Speer 2018:2)— traces back to Meiji, it offers a view into how punitive and supportive rhetorics and aims have co-constituted socio-spatial control across history. Blurry geographies viewed over time can telegraph the shifting pace and tone of policy across political-economic restructuring. For instance, two discernable peaks in the synthesis and deployment of technologies emerge in the 1920s and 2000s, each spanning decades. The first overlaps with expanding imperial claims to socio-spatial control (i.e. public assets and services) through democratization and doctrines of "benevolent" public service. Here, care and clearance became so enmeshed in technologies they seem reversed, with police leading aid distribution and social agencies sending vagrants to labor colonies. The latter decades overlap with the neoliberal privatization of socio-spatial control, justified as a people-centric liberation from state rule accompanied by de-democratizing forces like marketization of politics. Here, policies advance privatized re/development in similarly enmeshed form by mobilizing police and infrastructure agencies alongside new modes of welfare provision to oblige relocation. Interestingly, socio-spatial effects in each era include blast points (e.g. parks) and capture points (e.g. Sanya; Manchuria) illustrating control over people and spaces, under both expanding and shrinking state functions.

Also salient is the state's enduring exclusion of housing-insecure populations from democratic publics across and between both eras. This gap between "political freedoms implied and [political limits] experienced” (Kelly and Kaplan 2004:140) is exemplified in not only exclusion from universal systems, but also conditions of 
insecurity and indignity propagated via limited aid. Continuities underscore homelessness regulation's originary function of limiting claims to autonomy—often through, rather than despite, avenues to aid. That is, post-war systems upheld prewar logics and structures designed to enforce limited democracies, which effectively signal a transnational failure to democratize policy systems in the mid-twentieth century. Moreover, the deployment of historically-entrenched tropes associated with penalwelfare structures effectively channels public energies into established paradigms of socio-spatial control (Greene 2014) shrouding and propagating exclusions from social citizenship.

Undoing Imperial Formations

In describing revanchism, Smith (1996) inverts the language of imperialism as he introduces "dark and dangerous" forces of gentrifying "pioneers" wishing to cleanse and reclaim urban frontiers via civil-izing gentrification projects. This characterization offers a unique corrective to historically-entrenched tropes portraying marginal groups as the “dark and dangerous” threats. While his “dystopian” narrative may not provide a full account of neoliberal governance, inclusive of care and ambivalence (DeVerteuil 2012), Smith (1996) does pointedly challenge modern ideas of progress predicated on "taming" people and places. In doing so, he lays domination and the imperial formation bare.

Pushback against revanchist theory has produced a fortunate boon of investigation into the hybrid and intertwining Janus-faced forces of modern regulation. However, this nuance also carries risks. Legacies of empire, by definition, produce a “world conceived in binary terms” (Bhabha 1994:20) in which power negotiates for itself 
more nuance and sympathy. Pursuing nuanced views should not be motivated by our own imperial desires to absolve the present of intentional violence and, instead, relegate it to the past, or otherwise evade reckoning with actual violence in uneven power structures that “darken” the name of today’s civilizing agents—-who are us. We should seek evidence of care, but not solace or pardon by its presence. As Murphy (2009:323) notes, compassionate strategies do not hinder "marginalization... even if some... can be read as kinder and gentler”. Care is often complicit in systematic dehumanization and a far cry from justice.

Imperialism, by definition, regards itself as superior to anything else. In the context of homelessness regulation, this includes actual means employed by people to survive. Socio-legal arrangements propagated under this pretension—ones that unilaterally determine what social existence is legitimate-deliberately deprive people experiencing homelessness of "full personhood” (Feldman 2004), which also absolves the state of responsibility for their well-being. Tokyo’s policy history shows that compassionate and supportive measures-like their corrective and punitive counterparts—-fail to genuinely account for the needs and interests of housing-insecure populations. Instead, they offer anti-democratic responses that constrain socio-spatial mobility and liberties. History evidences that failure to ameliorate homelessness is neither rooted in corrective or therapeutic approaches per se-nor is it resolvable by them. Rather, to achieve these ends, there must be an undoing of the fundamentally hierarchical, patriarchal, and anti-democratic imperial formations delegitimizing homelessness itself. 
Ending "the revanchist city" of clearance requires abandoning its twin, "the seductive city” of care, and ensuring that people have fundamental social, political, and economic rights - and tolerant space (Murota 2017) wherever they choose to be. Policy configurations that invalidate the right-full existence of persons experiencing homelessness, sustained under global and locally-situated processes of modern capitalist development, have propagated anti-homeless "revanchist” urbanisms and injustices across history. Undoing imperial formations requires, above all else, legitimizing and protecting homeless existence. Homelessness regulation under any other conditions will remain, by design, anti-democratic and weighted against the interest of resolving homelessness, no matter how innovative frameworks may otherwise seem. 


\section{CHAPTER 4. COMPASSIONATE ACTORS \\ URBAN REDEVELOPMENT AND THE POLITICS OF CARE}

Introduction

In Tokyo and Kuala Lumpur (KL), profound change has taken place in regulation of homelessness over the last twenty years, especially considering prior policy stability since the 1960s, owing to rapid-fire advance of new regulations, protocols, and programs under myriad government agencies. In both cities, policy reforms began heading in a new direction as civil society organizations (CSOs) took up the banner of addressing and reducing homelessness through the provision of direct aid, which clashed with state aims of reducing the visibility of homelessness through public order measures. In Japan, this began in the mid-1990s when the Tokyo Metropolitan Government launched mass evictions targeting encampments in Shinjuku Station. In KL, it began with increased civic interest and action regarding homelessness in the late 2000s and accelerated in 2014 when federal authorities attempted to clear the capital of homelessness during Ramadan. In subsequent years, friction between public concern for the rights and well-being of unsheltered persons, on the one hand, and state interest in improving the image and marketability of the city via enhanced public order governance, on the other, has birthed multiple waves of new policies and approaches.

Japan's cascade of modifications began with the 2002 Self-Reliance Support Act, which marked the central government's recognition, as per Article 1, of its "duty to provide routine support to prevent homelessness... [and] bolster self-support among the homeless" under an aim "to direct resources [to remedying homelessness] in line with 
rights protections, and advancing civic understanding and cooperation". These duties and aims committed government agencies to efforts that had been sidestepped for decades under Tokyo's devolved welfare system between the 1970s and 1990s. Subsequent measures included the metropolitan-level Transition-to-Community-Life Program (20042009), which offered subsidized housing to persons occupying tents in five of Tokyo’s major parks and ward-level housing-first projects (2017-present), as well as policy reforms such as the 2008 revision of Livelihood Protection Act guidelines to ensure universal access, including by people historically turned away for their presumed “capacity to find work”.

Similarly, in Malaysia, burgeoning public interest in expanding aid has prompted the federal government to establish two new transitional shelters in KL and new forms of cash aid for low-income (including unsheltered) individuals and families. Also, with the accession of Pakatan Harapan and Prime Minister Mahathir to power in 2018, there has been a de facto break in KL's anti-vagrancy operations conducted under the Destitute Persons Act (DPA), Malaysia's central policy on homelessness and a vestige of British colonial vagrancy law. In each city, forceful opposition by CSOs to harsh public order measures led to new public and civic sector partnerships that brought CSOs into policy formulation and implementation. From the perspective of CSOs, such partnerships have produced what would seem to be fresh opportunity to effect policy change-but they have also fractured CSO networks as CSOs who do—and do not—align themselves with government programs are pitted against each other not only in terms of ideological difference but also by uneven distributions of resources and power. 
Moreover, even as CSOs have proceeded to advance more constructive agendas of compassion and aid vis-à-vis social policy, government agencies in each capital have proceeded to advance more rigid control over urban spaces, largely in support of re/development. In Tokyo, the displacement of encampment communities and individuals from urban landscapes through codes mandating "appropriate use" of public land—a

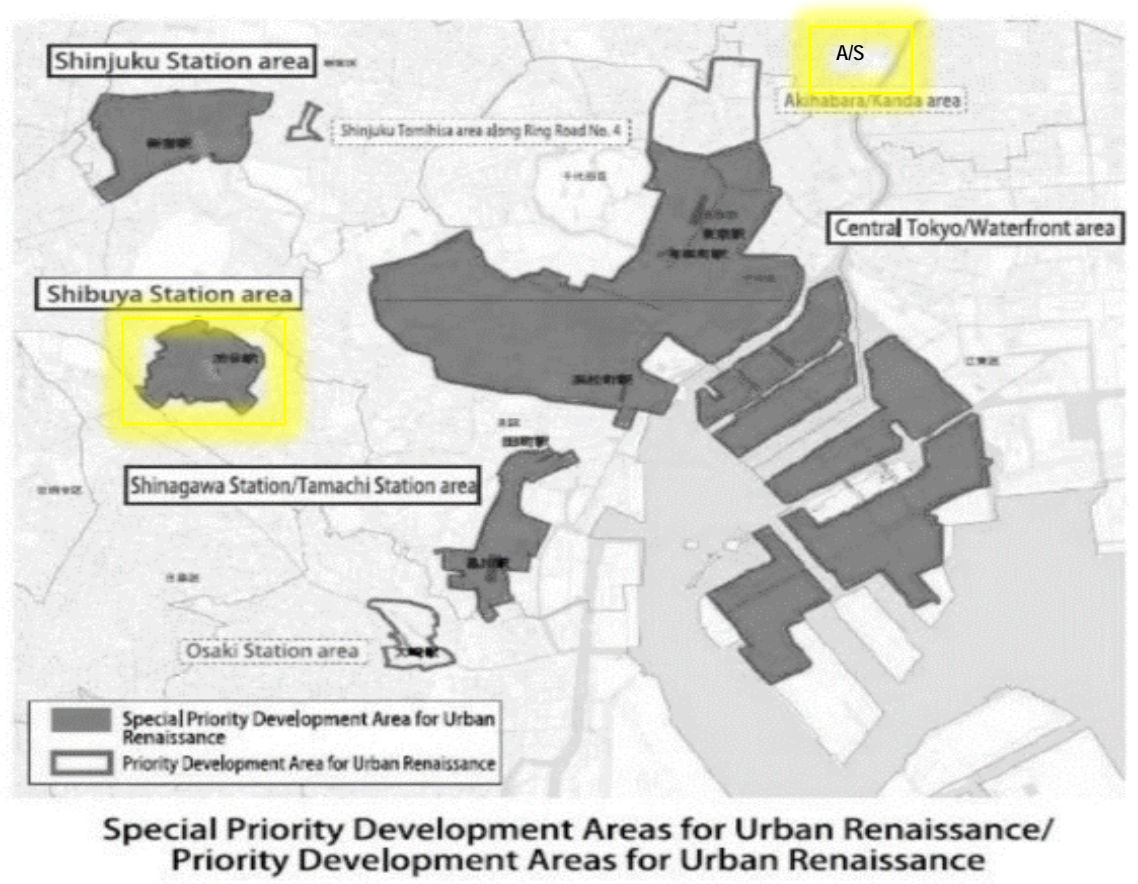

Figure 4. Map of Special Priority Development Areas for Urban Renaissance (shaded).

* My primary field sites include the highlighted areas of Shibuya Station and Asakusa/Sanya (marked "A/S"; added by author).

Source: Tokyo Metropolitan Government (n/d). Bureau of Urban Development

euphemism introduced in the 2002 Self-Reliance Support Act and applied as a

prohibition against survival activities conducted while homeless—has proceeded

alongside re/development projects. Redevelopment initially came into vogue as it

targeted underground corridors in the 1990s before picking up pace in commercial

districts and waterfront regions designated Urban Renaissance Urgent Redevelopment 
Areas (Figure 4) under a 2002 national law ${ }^{38}$ designed to "enhance the attraction of cities and their international competitiveness”. In KL, DPA rescue operations and related institutions have been expanded by federal agencies as public and private sector agents have rushed to fulfill Malaysia’s 2010 Economic Transformation Program (ETP), which

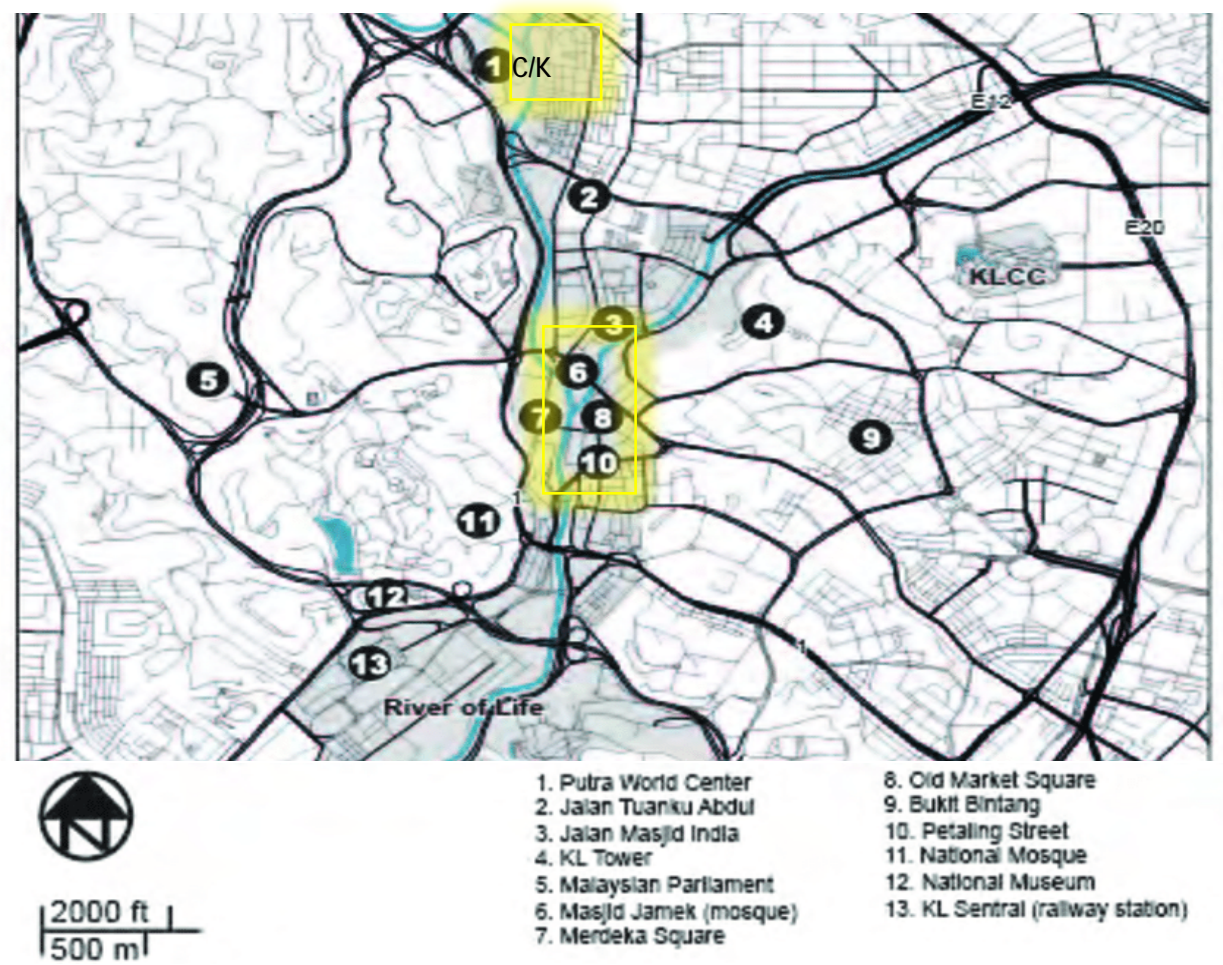

Figure 5. Map of central Kuala Lumpur, showing the River of Life area.

* My primary field site aligns with (6) Masjid Jamek Mosque, (8) Pasar Seni, and (10) Petaling Street, which may be crossed by foot in 20 minutes. )

Source: (Stevens et al, 2016)

includes the transformation of KL's downtown district, where homelessness has historically concentrated, in line with the River of Life (ROL) project (Figure 5). Consequently, in both cities, people experiencing homelessness are not only targeted by public- and civic-sector outreach programs but are also regularly monitored and interrupted by public- and private-sector agents linked to development policies, including

\footnotetext{
38 The Act on Special Measures Concerning Urban Reconstruction
} 
municipal officers, transportation and sanitation workers, police officers, and security guards.

Hannah Arendt (1965:79; see also Degerman 2019) calls attention to dangers inherent to compassion mobilized in the public sphere, especially as a political instrument, owing to its proto-totalitarian potential for being "enjoyed for its own sake, [which] almost automatically lead[s] to a glorification of its cause, which is the suffering of others". This tendency was indeed visible in shifts in homelessness regulation in imperial states_-including Japan — over the first half of the twentieth century, when imperial and colonial authorities wielded benevolence, among other strategies, to justify discrimination and uneven power. Compassion, as constructed in today's socio-political order, is prone to carrying paternalist tendencies that embed in policy the power of compassionate actors. Such paternalism ${ }^{39}$ has been linked to "incoherency, inconsistency, bias, [dysfunction] and possible corruption" in public function (Kato 2015:36) and, furthermore, undercuts democracy to the extent that "categories of gender, race, caste, ethnicity, nationality, and...social class... translate directly into categorical differences in political rights and obligations”, as histories of liberal democracy show (Tilly 2007:75).

Between 2018 and 2019, I spent twelve months in Tokyo (February 2018 February 2019) and six months in Kuala Lumpur (February - August 2019) observing which public policies are currently enforced, how they are enforced, and what conceptions of homelessness that underlie enforcement decisions. A majority of my time

\footnotetext{
39 This paternalism underlies the proliferation of extra-legal systems like Japan's extra-legal aid (hōgai enjō) or Malaysia's rescue operations (operasi mengyelemat).
} 
was spent interviewing and "going along" (Kusenbach, 2003) with people experiencing homelessness to observe policy agents and policy artifacts intersecting with and impacting their lives. This chapter details their engagement with a wide range of compassionate actors, including public officers in open spaces and voluntary agents at CSO-run food distributions. In light of research on the de-democratizing effects of neoliberal marketization in public life, public space, and politics (Tilly 2007; Brown 2015), I interrogate whether the increased inclusion of civic organizations and related supportive, or compassionate, ambitions in policy processes marks a substantive shift towards enhanced democratic governance in Tokyo or KL.

For decades, the fusion of government and non-government institutions and aims has been assumed to have a progressive political effect, as most popularly argued by the United Nations in its Local Agenda 21 initiative. Based on my fieldwork in each city, here I consider how CSO involvement and its legitimation by the state relate to social and spatial governance-and its democratic foundation.

Public Goods and Public Good

Framing the problem: Public agents, perspectives, and powers

—-Site 1. TOKYO: The inappropriate nature of homelessness

In June 2005, Tokyo launched the Transition-to-Community-Life Program in Yoyogi Park by opening a small prefabricated office (see Photo 1, page 153) for counseling and registering potential applicants from among over 300 Park encampment residents. The metropolitan government already completed two rounds of registration elsewhere: first in Shinjuku, Tokyo’s administrative capital, and second in Sumida Park 
by the famed tourist destination of Asakusa. While the metropolitan government arranged for substantial press and fanfare around the launch of this, Japan's pilot Housing-First program, it did not widely transmit information on program terms and eligibility. Articles noted that registrants would receive subsidized housing for 3000 yen per month, and access to public work programs. However, they rarely included that eligibility was limited to people already residing in encampments—only in five designated parks_rather than anyone experiencing homelessness generally. Outreach and registration activities were managed by CSOs like Yurin Association, the quasi-governmental organization responsible for Yoyogi Park’s office. For over 40 years, Yurin Association has acted as a provider of homelessness-related services for multiple municipal governments.

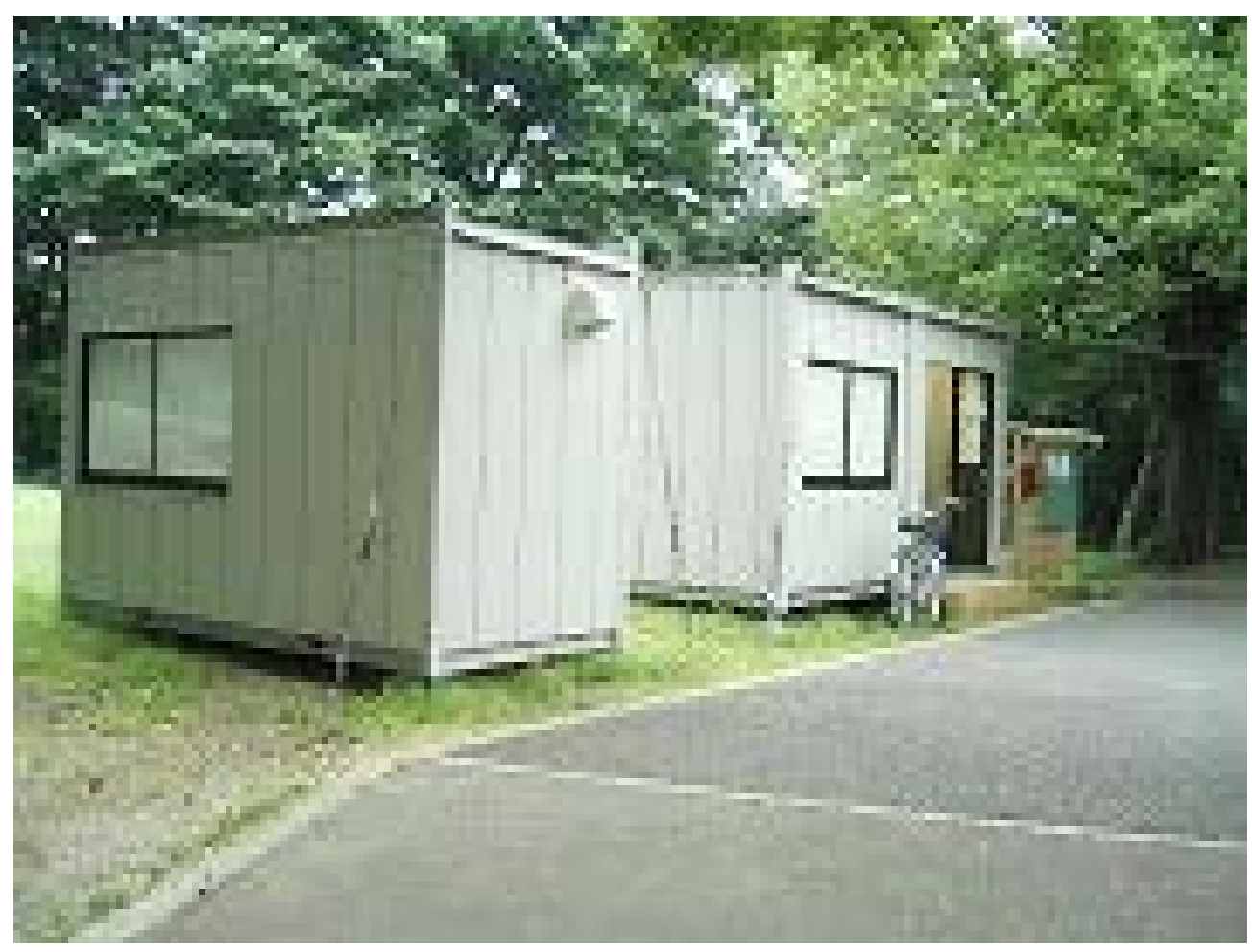

Photo 1. The Transition-to-Community-Life office in Yoyogi Park, 2005. Source: (Murakami, 2005). 
The Program immediately attracted widespread public interest, especially since it came on the heels of the 2002 Self-Reliance Support Act and Japan's unveiling of selfreliance shelters nationwide. Moreover, because the Program was Japan's first attempt at a Housing-First model, it gained support from numerous CSOs, some brought on as implementing agents. At the same time, many CSOs expressed skepticism as metropolitan government officers refused to answer key questions, such as whether housing contracts would be renewable after their four-year baseline, and whether people declining housing would be permitted to stay in parks. Without assurances in either direction, many encampment residents feared the Program was a bait-and-switch: that the offer of temporary housing would be used as a tool to later justify park clearance. Over time, questions of whether to work with or against policy produced tensions among CSOs also, weakening relationships despite decades of history collaborating.

While welfare-oriented public agencies and CSOs were at the frontlines of assistance services and housing provision, agencies responsible for urban infrastructure retained exclusive control over enforcing protocol for "appropriate use" of public facilities targeted under the Program's framework. For example, in 2004 the Tokyo Metropolitan Government’s Construction Bureau instituted its Terrace Improvement Office, responsible for the improvement (tekiseika, lit. corrections) of public space along Sumida River by reducing the number of tents ${ }^{40}$. Similarly, the Ministry of Land, Infrastructure, and Transportation (MLIT), responsible for monitoring national land like riverbanks near Asakusa and a national highway beside Shibuya station, also began

\footnotetext{
${ }^{40}$ Sumida River encampment residents in areas targeted by the Transition to Community Life Program were relocated to alternate sites or evicted after registration for the Program was complete.
} 
patrols—-today managed under its Policy Bureau Division of Planning for Secure Life (Sōgō Seisaku-kyoku Anshin Seikatsu Seisakuka), established around $2007^{41}$. Officers at these and other agencies continue to regularly patrol public spaces today.

In August 2018, I interviewed two officers from the Metropolitan Construction Bureau. Officer Tanaka was responsible for Asakusa’s Sumida River Terrace, while Officer Harada managed nearby roads and bridges. Officer Tanaka explained their aims as follows.

People who are homeless are managed under welfare, so they can consult experts at welfare offices. Our mission, however, doesn't allow for people freely using roads and waterways. Public infrastructure is a public good, and we can't allow people to just live there. At the end of the day, they must go.

National- and ward-level agencies also observe similar missions when monitoring public assets. Moreover, agencies have adopted uniform protocol for implementing policy, one that borrows from CSO strategies for outreach such as using greetings and engaging in conversation (see Figure 6, next page). By approaching people in this manner, agencies like the Terrace Improvement Office are able to communicate information on safety nets like livelihood assistance or Housing First programs. When I interviewed Metropolitan Government officers in charge of welfare policy, they expressed confidence that current measures were sufficient for addressing homelessness; in their view, the stickiness of homelessness as a social problem stems from insufficient public awareness of available

\footnotetext{
${ }^{41} \mathrm{My}$ research regarding this policy division is ongoing. At present, I believe it may have been established as part of a push for "barrier-free" transportation systems in 2007 and has—over time-become a policy division responsible for the interests of marginalized groups such as persons with disabilities, women, children, and persons experiencing homelessness. Management of homelessness under the MLIT's Division of Planning for Secure Life (Anshin Seikatsu) interestingly mirrors its management under the Community Safety Planning (Seikatsu Anzen) Division at the National Police Agency, where the difference between security/safety referenced in each relates to an individual's sense of security (e.g. relief from anxiety) in the first instance, and external security (public order) in the latter.
} 
programs and individual lack of cooperation. Ward-level agencies, on the other hand, expressed more nuanced views acknowledging gaps in policy and problems related to service providers. Simultaneously, however, they too stressed the importance of outreach for informing people experiencing homelessness of options. Hence, government agencies see outreach as a core, indispensable strategy.

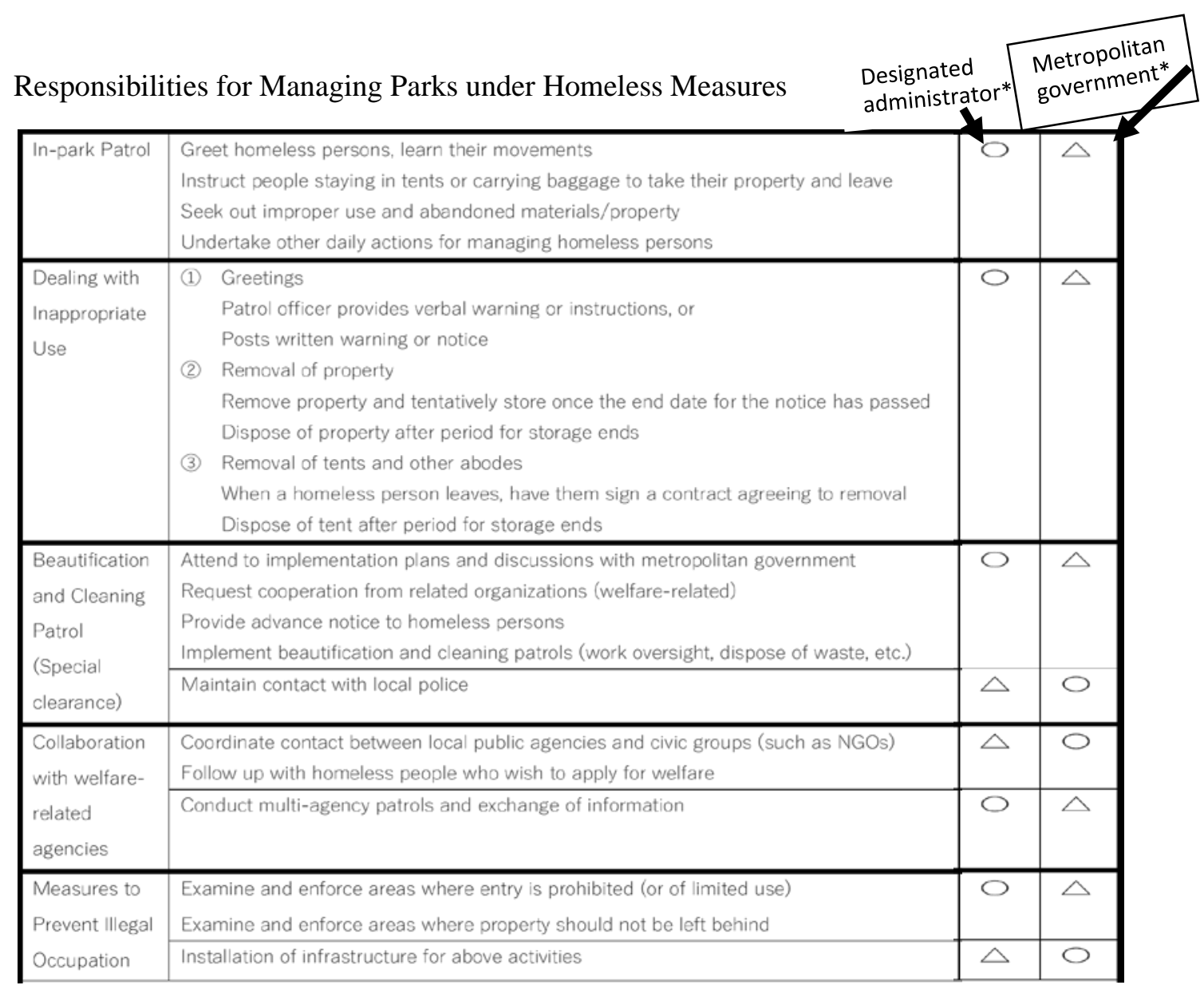

Figure 6. From the Homeless Measures Manual on Improving Park Management.

*Explanation of coding missing from original

Source: TMG Construction Bureau (2016:16; Translation by author).

However, most scheduled patrols targeting public facilities are conducted not by welfare officers, but by public agencies or designated administrators responsible for public assets. As shown in Figure 6, these agents are obligated to "seek out improper 
use”, warn against such use, "instruct people...to take their property and leave”, and "undertake other daily activities for managing homeless persons". The expected outcome is a trip to the welfare office voluntarily taken by policy targets (Figure 7). This appears as a success because homelessness is presumed to be foremost a welfare matter. Consequently, the Tokyo Metropolitan Park Association, a quasi-government agency dedicated to researching park matters, reports that these patrols "send out public officers, sometimes in teams of ten or more, to ensure [facilities] are more safe, secure, and pleasant for users ${ }^{42 ”}$ (TMG Construction Bureau 2011:2). In 2016, the Construction Department publicly reported that "pro-active measures targeting homeless persons have proven valuable and we plan to sustain them as means to improving...security and satisfaction $^{43 "}$ (TMG Construction Bureau 2017).These assessments make clear that
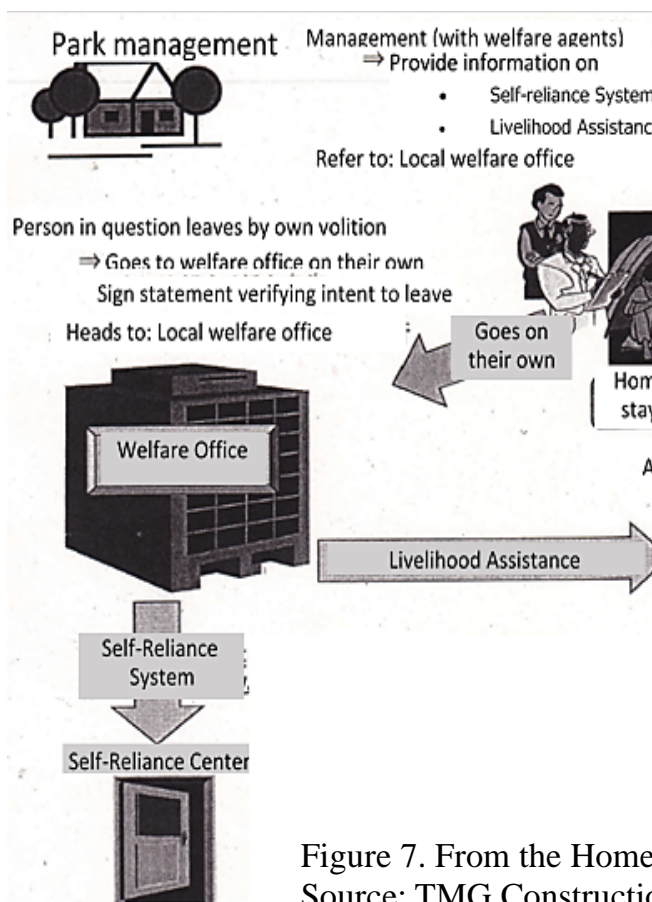
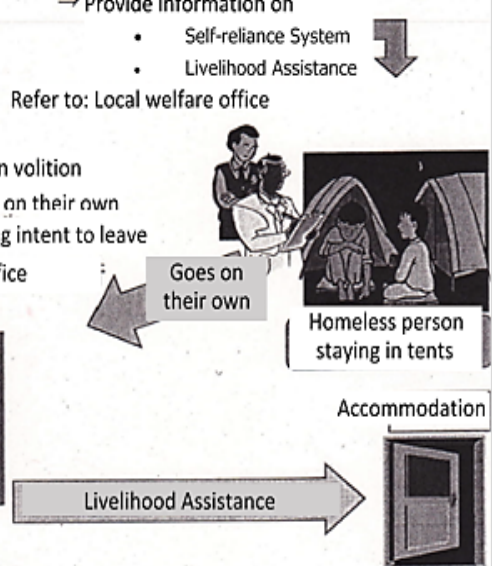

Figure 7. From the Homeless Measures Manual on Improving Park Management. Source: TMG Construction Bureau (2016:22; Translation by author)

\footnotetext{
${ }^{42}$ In Japanese, "Sūjūnin kibo no shokuin de sagyō suru dai-kibo kyōdō sagyō nado no kufū ni yori, anshin anzen na kōen dzukuri, kaitekina kōen tdukuri ni torikunde iru."

${ }^{43}$ In Japanese, "Hōmuresu taisaku... heno sekkyoku-tekina torikumi ha ōini hyōka deki, kongo mo keizoku shite kōen no anzensei kaitekisei no kōjō ni tsutomeruyo kitai suru."
} 
while policy outcomes are evaluated based on benefit to "park users", people experiencing homelessness are not included therein.

When I returned to Tokyo in 2017, I met with Kei, a woman in her mid-40s and one of under 30 remaining encampment residents in Yoyogi Park. When I asked her about her experiences with the Transition-to-Community-Life Program, she began by remarking that Yurin Association had been very helpful during their tenure, offering the example of their intervention into a matter of domestic violence. For this reason, she explained, Yurin seemed interested in assisting all encampment residents, and not just those planning to enroll in the Program. However, she continued, after registration was complete and Yurin left, park management officers began conducting more interventionary patrols that involved dictating new rules regarding park use. According to $\mathrm{Kei}^{44}$, officers took pictures, identified new infractions, and otherwise strained residents' day-to-day lives. "No matter what we did," she noted, "they always found ways to pressure us into thinking we couldn't stay. They started micro-managing our everyday lives to prevent us from doing what we normally did to get by."

Changes included enforcing new rules governing the appearance and structure of tents, which affected whether and how residents did laundry or stabilized shelters against storms. Kei continued, “They weren’t explicitly telling us we had to leave but it was like they were thinking of how to make things difficult for us. Some days, they'd approach someone who was sick or old and ask them, 'Why are you still here in that condition? You should go.'” She also noted that when tent residents requested assistance from park

\footnotetext{
${ }^{44}$ October 10, 2018 interview.
} 
management-like when they saw peeping toms lurking in the woods in spring and summer hoping to catch women urinating - the office would only half-heartedly respond, if at all. Kei has grown accustomed to management's selective attention. Moreover, she has no choice but to sustain tense engagement with officers from other agencies such as the Metropolitan Construction Bureau, Shibuya Ward’s Parks and Greenery Office, and the Tokyo Metropolitan Park Association.

Officer Tanaka of the Metropolitan Construction Bureau offered insight into why taking record of people identified as homeless has become standard practice. Tanaka patrols an area along the east side of Sumida River spanning 15 kilometers, or about 50 tents, and patrols this area each week. He engages not only tent residents but also anyone who appearing homeless. He explained that information collected during patrols, when shared internally, helps officers build rapport with targeted individuals and, ultimately, convey advice.

We let them know the benefits of livelihood assistance. Here, they have no heating or air conditioners, and they can't use fire...but [through livelihood assistance] they can move to an apartment-a one-room apartment—with a kitchen and water. They can be normal, like us, and take baths and showers, use a kitchen, and have AC. Our duty is informing them that the welfare office will provide aid-and, after that, they cannot camp like this again.

The protocol for engaging people deemed homeless stems from duties assigned by the 2002 Self-Reliance Support Act, stipulating that public officers must provide information on welfare assistance, while also enforcing standards of "appropriate use". Consequently, despite agreement among public agencies that homelessness is a matter of welfare, laws and practice governing homelessness reveal a blurring between practices of managing people and those managing public space. Hence, just as welfare officers now regularly 
patrol public spaces for outreach, non-welfare agencies have cemented clear protocol for engaging and even advising persons experiencing homelessness.

The Construction Bureau's mission to scale down "inappropriate use” of public space also colors officers' perceptions of other actions by people experiencing homelessness. For instance, Officer Harada, responsible for roads, also described his concern regarding their poor choices, or behavior, as follows.

It would be a relief for us if they went on welfare. These people earn money collecting aluminum cans...but, frankly, that's stealing... [T]hey carry around large bags (like thieves) and fill them with bottles and cans, even though there are signs stating it's a crime. They don't even earn as much as they would like.... They should just take livelihood assistance.

Harada's personal view expresses a measured rationalism that condenses people's options into two categories: accepting, or refusing, Livelihood Protection. However, the system of values that compels him to conclude that accepting welfare is the only rational choice—or, in Tanaka's words, solid avenue to "be[ing] normal, like us"—is relatively new. Since its postwar occupation, “dependency” on Livelihood Assistance has been stigmatized—and this stigma has only recently been reduced since 2004. The compassionate argument for welfare's importance made by each officer is grounded less in compassion and more in institutional norms that present the refusal of welfare as misguided, or "inappropriate", owing to potential harms to the individual and society. This view—often manifested in the words and actions of agents, as Kei explained—tends to underlie tensions between them and the targets of policy. 
—Site 2. KUALA LUMPUR - People in trouble... or causing trouble I returned to KL in February 2019, after 18 months in Tokyo and a 5-year absence. Immediately I discovered exponential growth in the number of CSOs distributing food, offering medical services, and otherwise conducting outreach. Since homelessness began receiving national attention in 2014—and especially since City Hall began running KL's newest shelters since 2016 — government agencies have been asking CSOs to follow "proper channels" by directing aid and services to governmentestablished facilities, rather than going to people on the streets. Government agencies justify these appeals by arguing that CSO action without government coordination wastes resources by poorly distributing them. As in Tokyo, government agencies like City Hall aim to bring CSOs into policy and programs, often using the carrot of subsidies and influence, and the stick of public censure. Hence, over time, CSOs have been integrated into policy processes, including as implementers of PIT counts, participants in policy consultations, and advisors or leads in research activities. However, many groups also openly disregard government advice. On Hang Lekiu Street, where I spent three nights each week doing fieldwork, I saw about 5-10 organizations independently (without government coordination) delivering anywhere from 15 to 150 meals each, and even more on weekends. All passed notices informing the public not to "give food or material items to people on the streets" (see Photo 2, page 162) but to instead distribute them through Anjung Singgah, KL's first homeless shelter, just 30 meters down the road. 
The halt of anti-vagrancy operations in KL, after Pakatan Harapan ${ }^{45}$ took power in late 2018, appears to have been motivated by a desire to avoid courting tension with CSOs, given recent (2014-2017) upset over anti-vagrancy operations—especially since civic movements played a large role in facilitating the party's rise. Although night-time anti-vagrancy operations were informally suspended in KL (that is, without any formal declaration of a halt), daytime anti-begging operations continued uninterrupted. This shift in targets-from people sleeping on the streets to those begging, both stipulated under Malaysia’s Destitute Person’s Act (DPA)—is likely meant to compensate for the state's truncated ability to enforce the DPA vis-à-vis vagrancy. It appears that the Welfare
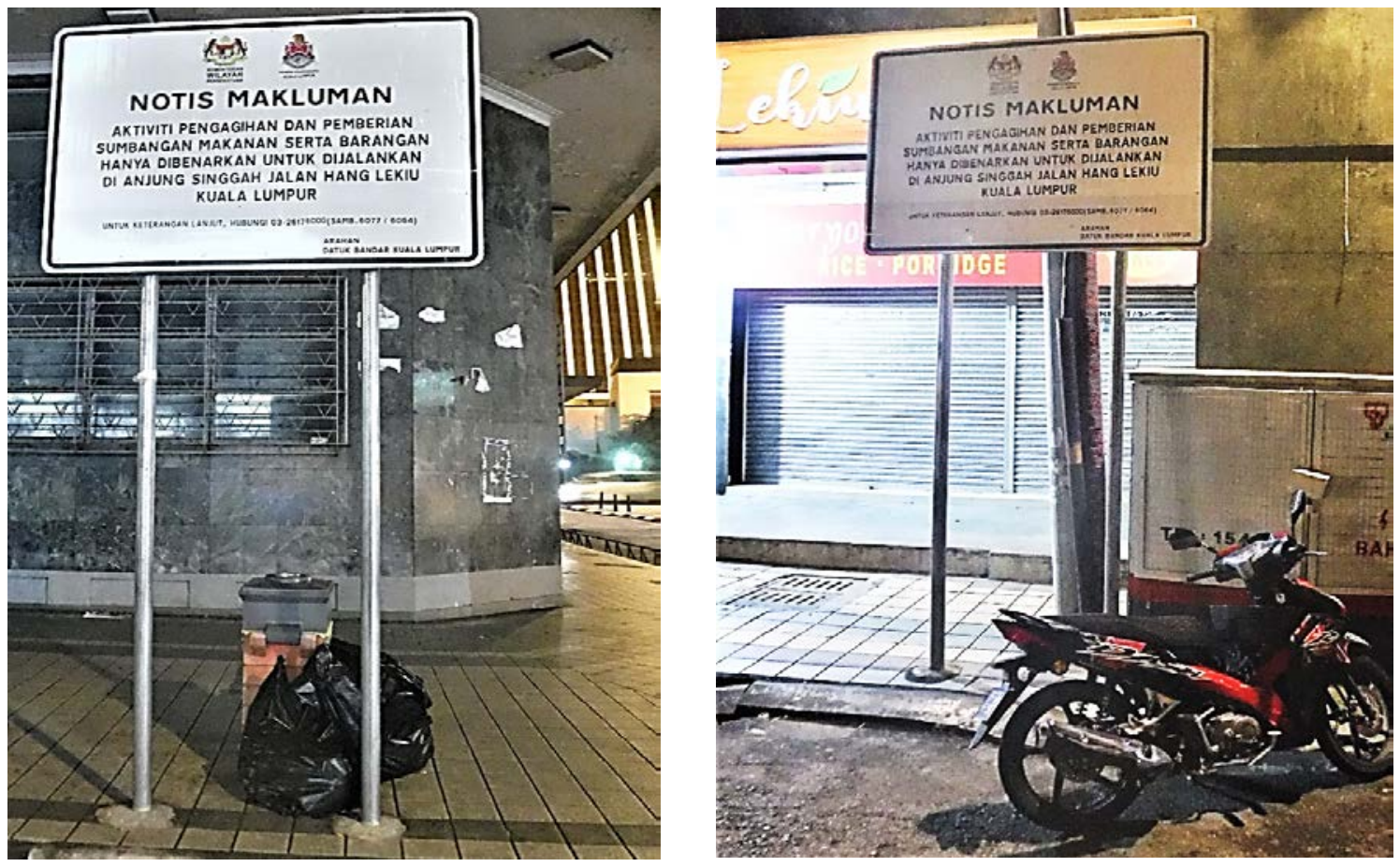

Photo 2. Signs posted by Kuala Lumpur City Hall on Hang Lekiu Street. Photographs by author.

\footnotetext{
${ }^{45}$ Malaysia's first opposition party to win a federal election over Barisan National since independence in 1957.
} 
Department in charge of DPA enforcement has decided to capitalize on largely unchallenged negative views of begging to fulfill objectives of reducing or, in government lingo, "rescuing” so-called destitute persons ${ }^{46}$. The shift of operations from night-time to daytime has been received positively by people sleeping rough as most can now rest at night without fear of capture. However, people earning income from begging—disproportionately women, persons with disabilities, senior citizens, and refugees—now grapple with greater risk of DPA arrest.

Azleena, a 46-year-old trans Malaysian-Malay ${ }^{47}$ woman, told me in an interview that she was caught twice in anti-vagrancy operations, just prior to their halt. When I met her, she was not sleeping on the streets but rented a partitioned room ${ }^{48}$ in Chinatown, which she afforded through sex work and help from friends, alternately. Like many people, she cycles between the rented room and homelessness, depending on her ability to find funds ${ }^{49}$. She also kept her room open to trans and gay youth who would stop to rest, some of whom referred to her as their mother. In summer 2019, she said ${ }^{50}$, she was sitting on Hang Lekiu Street with a large bag that kept her from running when officers appeared.

\footnotetext{
${ }^{46}$ Generally, CSOs insist that begging and homelessness do not overlap; research by Rusenko and Loh (2014) and Syafiq and Selvaratnam (2018) show otherwise.

${ }^{47}$ In Malaysia, convention is to identify ethnicity after Malaysian. People therefore identify as MalaysianMalay, Malaysian-Chinese, Malaysian-Indian, etc

${ }^{48}$ An informal-sector room for rent. Malaysia's traditional two-story Chinese shoplots are often partitioned into 7'x4' cubicles on the second floor, and rented out for 20 Ringgit per night.

${ }^{49}$ Some persons, but not Azleena, qualify for disability or senior assistance and can use that income to double up with a friend to rent rooms, for example.

${ }^{50}$ June 14, 2019 interview.
} 
[One officer] said, if you cooperate with us, you are invited to the lorry, but if you refuse we will force you inside. So, I thought, what can I do? I just take my belongings and go inside the lorry. In my thoughts, I worried I was going to be sent to a camp... [because] the government has the right to arrest [people on the street]... [Once] we arrived at City Hall headquarters ... they grouped us and then asked for IDs... [After two hours] at 3 or 4 o clock I was called.... [and] they asked me what I was doing [outside]. I explained I was resting... and they released me, but they don't send us back. We had to walk. You know how far it is?!

The walk takes one hour for someone healthy, without physical limitations. It takes more for people who are older, disabled, or unwell and is dispiriting for anyone who has been kept up all night for drug tests and questioning. Azleena noted that Social Welfare detained one man who was "rather like childish", and that immigration and police agencies drove away with several arrestees each. She also added that, on a separate occasion, the government van drove her and 10 others straight to Rawang, 20 miles outside of KL, and abandoned them on the side of the road. Although this practice dates back decades, it now makes the news as CSOs have begun to protest its inherent cruelty. As night-time operations have receded and CSOs provide evening meals, Hang Lekiu Street takes on a buoyant energy after dark, especially during its busiest hours of 810pm when over 100 people gather to eat, rest, and chat. However, not all people relying on these meals are homeless. Approximately one-third join from nearby public housing complexes and partitioned rooms. Interestingly, I found that many people attendingregardless of age or geographic origin—saw CSOs as an extension of the government, that is, as bona fide government actors ${ }^{51}$. Thomas, a 33-year-old Malaysian-Indian

\footnotetext{
${ }^{51}$ Such confusion is unsurprising, as political parties in Malaysia have co-opted or created NGOs to serve as the face of party interests, and voluntary government agents - such as RELA, a voluntary police forceare both prominent and widely popular. Hence, as with Japan, the outsourcing of social programs to non-
} 
sleeping on the streets while he is between jobs, responded to my question about the duties of the Social Welfare Department as follows ${ }^{52}$.

Thomas: [They come] down to give donations, food, and necessary items.... Rayna: You see the Department doing this? (Points to people passing out meals.)

Thomas: Oh. It's hard to know, because they don't have uniforms. He could be staff, or maybe he's from an NGO.

Although I initially assumed this mix-up stemmed from his confusion, over time I realized that most people did not differentiate between CSOs and public agencies, and that this was because CSOs were becoming the face of government policy. For example, Loh, in his late 40s, told me that "Every day we have NGOs come and give food. This is how the government takes care of us and I should be thankful to the government for that ${ }^{53}$ ”. CSOs not only distribute food from government shelters and conduct surveys on behalf of agencies but, as Thomas pointed out, public officers patrolling the streets are rarely in uniform anyway.

The most common example would be plain-clothes police-typically young men walking in groups of three or more-who patrol Jalan Hang Lekiu 3-4 evenings a week. Regular patrolling enables them to identify who is new, for questioning. Thomas said they often approach newcomers, to see if they are using drugs or "ask for their ID to [check] ...if they have jumped bail”. Older men who are less likely to be suspected of

\footnotetext{
government actors occurs under neoliberal policy models that seem to offer greater political power, and economic burden, to civil-society, justified via market-oriented and social responsibility rationale.

${ }^{52}$ May 7, 2019 interview.

${ }^{53}$ I have also heard this response in regard to operations, and I understand it is a relatively safe response for an authoritarian context. That is, for example, even where people would talk about the failure of operations, and I would ask for their advice on how to improve, they would assure me that they were grateful that at least the government tried something.
} 
illegal behavior tend to welcome the patrols, believing that frequent police checks deter hardened criminals and drug use, which they fear could bring more danger. Younger people, like Thomas' friends that evening, are more ambivalent. They explained they felt like targets and often dealt with questioning. Most said that, as a precaution, they avoided the area until they were ready to sleep. Their avoidance is interpreted as policy success by some older people who view them as delinquents.

Stereotypes of people experiencing homelessness—and especially youth—as prone to criminality justify intense policing of their public behavior. Fazil, a man of Malay and Chinese descent is in his late 40s, explained ${ }^{54}$ that police presence was for the better because "here, where there are so many homeless people, things can go wrong." Badi, a Malaysian-Malay man in his early 40s and new to the streets, was arrested shortly after I first met him. I heard from his friends that he mistook a plain-clothes officer for an acquaintance and ran up to the officer yelling. When he returned from jail one month later, I asked whether the arrest upset him. He said ${ }^{55}$, "I was Army, so I know what law is for. Malaysia has its laws, and I broke the law." Badi and many others spending time on the streets feel compelled to accept this policing — partly due to the power imbalance, but also partly out of fear, as they generally view, like Fazil, "homeless people” as markers of social and spatial disorder. Ultimately, people sleeping on the streets embrace—albeit reluctantly—state agents as protectors.

\footnotetext{
${ }^{54}$ May 2, 2019 interview.

55 July 13, 2019 interview.
} 
Redevelopment and regulation

—Site 1. TOKYO - The paradigm of steady decline

Data on homelessness reveals two shifts. First, while men have constituted over $90 \%$ of persons counted in national surveys for decades, average age has increased each year, reaching 61 in a 2016 national survey where over half (55\%) of respondents admitted being homeless over 5 years (MHLW 2016). Second, while the Transition-toCommunity-Life Program reduced the number of tents in Tokyo by $90 \%$ in 10 years between 2004-2014, government agencies at all levels have worked hard to further push this decline. This is reflected in the metropolitan government's annual count (Tables 3 and 4 below), initiated in 2003. For instance, results classified by jurisdiction and type of facility (top) show a steady decline across ward, and metropolitan, and national assets (top). Therein, metropolitan facilities show declines in parks riversides, which include both Yoyogi Park and Sumida River. Moreover, the rise until recently in people along

\begin{tabular}{|c|c|c|c|c|c|c|}
\hline & & 2019 & 2018 & 2017 & 2016 & 2015 \\
\hline \multirow[t]{4}{*}{ TMG } & Parks & $123(7)$ & $138 \quad 6$ & $126 \quad 6$ & $148(9)$ & 1936 \\
\hline & Roads & $181(2)$ & 2056 & 2036 & $195(2)$ & $137 \quad 6$ \\
\hline & Riverside & $51(0)$ & 55( & 636 & $70(1)$ & 816 \\
\hline & Subtotal & $355(9)$ & $398 \quad(11)$ & $392(13)$ & $413(12)$ & 4116 \\
\hline \multirow[t]{5}{*}{ Ward } & Parks & $158(11)$ & $162(6)$ & $210(9)$ & $213(15)$ & $210(13$ \\
\hline & Roads & $51(2)$ & $42(0)$ & $64(1)$ & $56(1)$ & $61(1)$ \\
\hline & Riverside & $12(0)$ & 86 & $10(0)$ & $5(0)$ & $17(0)$ \\
\hline & Other & $4(0)$ & 26 & $28(0)$ & $37(1)$ & $37<2$ \\
\hline & Subtotal & $225(13)$ & $214 \quad 6$ & $312(10)$ & $311(17)$ & $325(16$ \\
\hline Railway & & $22(6)$ & 186 & 26( & $31(3)$ & $54<6$ \\
\hline & & $612(29)$ & $646(21)$ & $754(26)$ & 772 ( 33 ) & $816<27$ \\
\hline
\end{tabular}

Table 3. 2019 Tokyo Metropolitan count of homeless people, by type of facility.

*In each column, numbers to the left are count results; numbers to the right are from previous year. Source: Bureau of Social Welfare and Public Health (2019a; Translated by author) 


\begin{tabular}{|l|r|r|}
\cline { 2 - 3 } \multicolumn{1}{c|}{} & 2019 & \\
\hline Chiyoda & 23 & 21 \\
\hline Chuo & 40 & 29 \\
\hline Minato & 24 & 35 \\
\hline Shinjuku & 117 & 124 \\
\hline Bunkyo & 9 & 11 \\
\hline Taito & 61 & 69 \\
\hline Sumida & 55 & 57 \\
\hline Koto & 31 & 32 \\
\hline Shinagawa & 12 & 15 \\
\hline Meguro & 3 & 0 \\
\hline Ota & 22 & 25 \\
\hline Setagaya & 9 & 6 \\
\hline Shibuya & 62 & 70 \\
\hline Nakano & 9 & 5 \\
\hline
\end{tabular}

\begin{tabular}{|l|r|}
\cline { 2 - 2 } \multicolumn{1}{c|}{} & \multicolumn{1}{c|}{2015} \\
\hline Chiyoda & $56(64)$ \\
\hline Chuo & $47(63)$ \\
\hline Minato & $30(56)$ \\
\hline Shinjuku & $70(121)$ \\
\hline Bunkyo & $17(15)$ \\
\hline Taito & $128(135)$ \\
\hline Sumida & $81(101)$ \\
\hline Koto & $30(40)$ \\
\hline Shinagawa & $10(12)$ \\
\hline Meguro & $2(4)$ \\
\hline Ota & $24(28)$ \\
\hline Setagaya & $17(18)$ \\
\hline Shibuya & $89(112)$ \\
\hline Nakano & $12(10)$ \\
\hline
\end{tabular}

\begin{tabular}{|c|c|c|}
\hline & 2004 & \\
\hline Chryoda & 183( & $206)$ \\
\hline Chuo & 198 & 168 ) \\
\hline Minato & 1596 & $139)$ \\
\hline Shinjuku & 982( & $772)$ \\
\hline Bunkyo & 726 & $123)$ \\
\hline Taito & $968<$ & 1,103 ) \\
\hline Sumida & 8486 & 981 ) \\
\hline Koto & 185( & $139)$ \\
\hline Shinagawa & 47( & $27)$ \\
\hline Meguro & 14( & 22) \\
\hline Ota & 103( & $105)$ \\
\hline Setagaya & 100( & $92)$ \\
\hline Shibuya & 574( & $533)$ \\
\hline Nakano & 56( & $70)$ \\
\hline
\end{tabular}

Table 4. 2019 Tokyo Metropolitan count of homeless people, shown by ward.

*In each column, numbers to the left are count results; numbers to the right are from previous year. Source: Bureau of Social Welfare and Public Health (2019b, 2015, 2004; Translated by author)

metropolitan roads underscores the particular focus on park and riverside assets, which have historically had higher populations. All other facilities-whether managed under ward or national agencies or by railway operators—show a steady decline. Tables in Figure 6 also illustrate steady reductions across most wards, except Shinjuku, Koto and Shinagawa.

Metropolitan counts occur during daytime hours, when persons experiencing homelessness are harder to identify in public spaces. Every year since 2016, one Shibuyabased CSO named ARCH has conducted a night-time count and consistently reaches totals 2-3 times higher than metropolitan counts. This gap makes the news each year (Over 1000 unseen 2020) and has inspired speculation as to whether public agencies are deliberately undercounting to minimize impressions of a problem. While this view has merit, I think the numbers also serve another purpose. Population counts are commonly believed to measure the efficacy of supportive policies, but I believe their design reveals 
intent to assess progress in enforcing "appropriate use" of infrastructure. These daytime counts necessarily concentrate on artifacts and people targeted in daytime patrols by the Metropolitan Construction Department and other administrators. Hence, these surveys speak volumes about not only the effects of policies, but also their intensity—and focus—on a very narrowly-defined outcome.

During my 18 months in Tokyo, I saw Shibuya’s landscape transform, especially surrounding Shibuya station. Shibuya closed Miyashita, its largest park ${ }^{56}$, for construction in 2017 with plans to reopen prior to the 2020 Olympics. Officers from Shibuya’s Parks and Greenery Office explained in an interview that they patrolled Shibuya's few remaining parks and adjacent open spaces like bridges and roads to enforce “appropriate” use where necessary. In late 2018, the Office began installing planters along walkways under bridges, such as on Mitake Road (see Photo 3, page 170). The officers admitted that planters serve as part of ward-level measures for addressing homelessness (hōmuresu taisaku) or, stated differently, effectively bar people from taking shelter in open spaces. Moreover, as Kenta called to my attention, ward officers had attached signs identifying planters as part of a work project for people with disabilities; this strategy was meant to undermine the possibility of protest by pitting the interests of two groups against each other.

On Saturdays, I attended an outdoor kitchen in Shibuya where volunteers and attendees—many homeless—shared information about the changing landscape. Small parks were being closed and barricaded, like one small garden in Jingu-Dori Park where

\footnotetext{
${ }^{56}$ While Yoyogi Park is larger in area than Miyashita Park, the former is managed by the metropolitan government while the latter is the responsibility of ward-level agencies.
} 
3-5 men slept. Also, people returning to Shibuya after taking up work, residence, or rough sleeping in another ward would comment that it was harder to find places to sleep in Shibuya. Private guards around Shibuya Station had grown stricter over the years and the availability of public space was in decline. For many people Shibuya was a lifeline because it is one of only two wards (of twenty-three) that has not criminalized cancollecting. Hence, the effects of metropolitan- and ward-level measures intended to
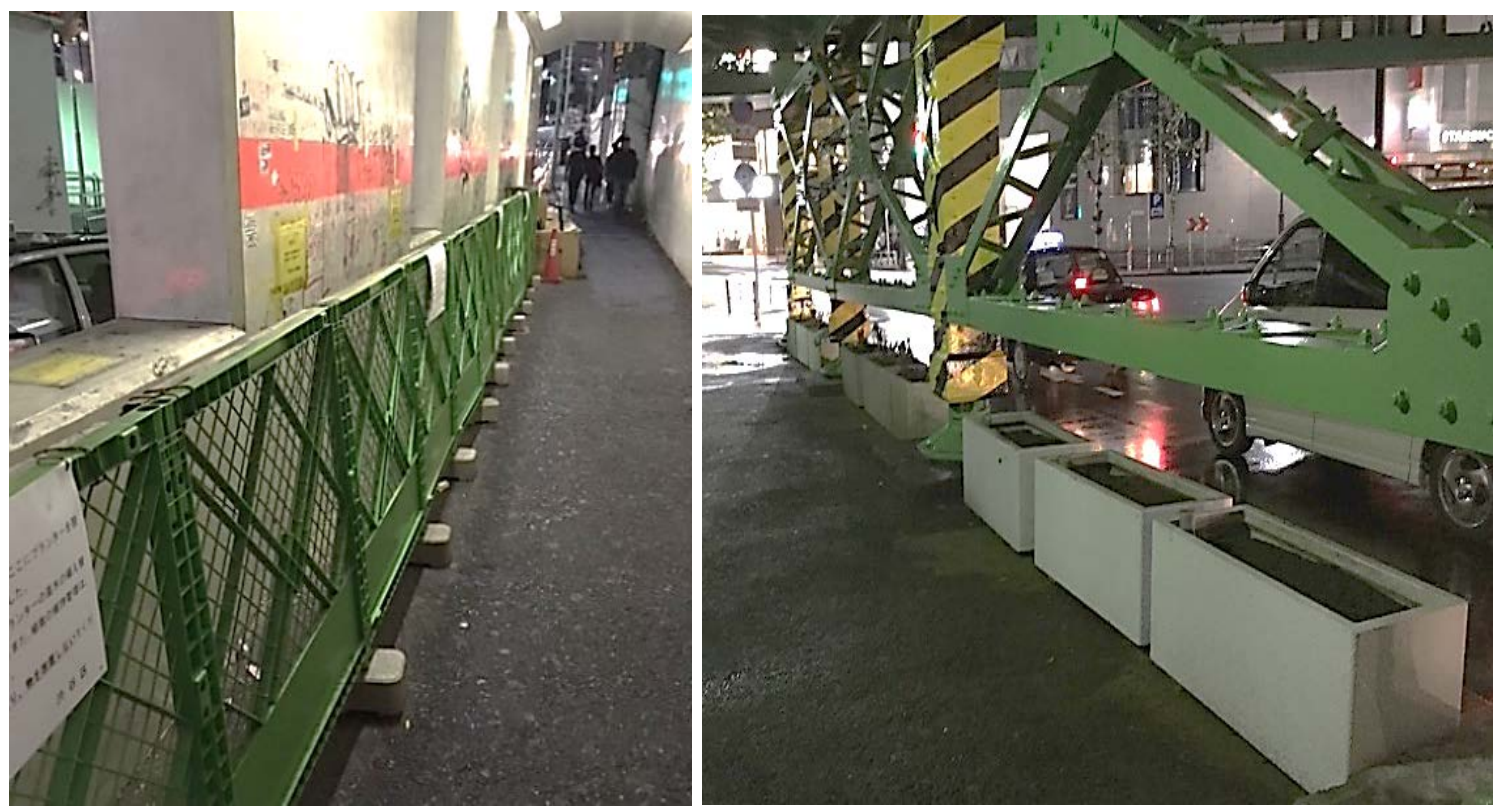

Photo 3. Barriers placed to prevent people from sleeping or resting beneath New Miyashita Park. One cardboard shelter can be seen at the far end. Planters were later installed (right).

(Photographs by author)

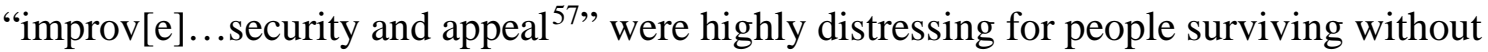
shelter (TMG Construction Bureau 2017). As a result of these and others changes, I found that many, especially younger persons with relatively greater mobility or access to income, felt compelled to either spend money on resting in internet cafes or restaurants, or leaving Shibuya for other parts of Tokyo.

\footnotetext{
${ }^{57}$ In Japanese, "kōen no anzensei, kaitekisei no kōjō."
} 
Among destinations, Tokyo’s historic day-laboring district, or Sanya, was most popular because of its social infrastructure, like public work programs (offering approximately \$75 for one day of work per week) or access to the Johoku Center’s 12hour drop-in center. Also, because homelessness has been concentrated in Sanya for decades, numerous CSOs regularly provide meals, medical services, counseling, and other support daily. While volunteering with one such organization in 2018, I met 76year-old Toya, a former day laborer who has been living and working in Sanya for decades_-both with and without shelter. He told me that Sanya continues to attract new people, which he attributed to public work programs. I asked whether he thought stringent security measures played a role and he responded that policing in Sanya has become, in his words ${ }^{58}$, "softer" over the last decade. Viewed together, policies have enforced decline by sustaining and even expanding Sanya’s public programs while also reducing exclusionary policing in the district to secure its role as a space for containment. Policies governing welfare, policing, and public infrastructure all play equal roles in determining spatial outcomes.

—Site 2. KUALA LUMPUR - Phasing out unilateral rescue, introducing choice Public agencies in KL are currently transitioning to a new paradigm for managing homelessness and evaluating policy. The previous paradigm emerged in the early 1960s as traditional vagrancy laws were modified to ensure both "care and control”, as stated in policy objectives. This produced the Vagrants Act, a welfare-oriented directive

\footnotetext{
${ }^{58}$ January 9, 2019 interview.
} 
facilitating the capture and institutionalization of people deemed vagrants or beggars in remotely located rehabilitation centers. From the Act’s earliest days, data has accentuated big numbers to underscore the reach of its operations, known today as rescue operations, and the Desa Bina Diri rehabilitation centers ${ }^{59}$ run by the Ministry of Women, Family, and Community Development (hereafter, Ministry of Women). National data since 2010 (Table 5) shows an increase in the number of rescued persons year-on-year, representing progress in responses.

\begin{tabular}{|l|l|l|l|l|l|l|l|l|l|}
\hline Year & 2011 & 2012 & 2013 & 2014 & 2015 & 2016 & 2017 & 2018 & 2019 \\
\hline $\begin{array}{c}\text { DPA arrests } \\
\text { (national) }\end{array}$ & 1,446 & 1,223 & 1,048 & 1469 & 1527 & 2278 & 4365 & 3472 & N/A \\
\hline
\end{tabular}

Table 5. Number of people rescued annually, according to Ministry of Women data.

Source: (Jabatan Kebajikan Masyarakat 2012, 2013, 2014, 2015:157, 2016:153, 2017:136, 2018:132)

I have not yet received clarification of who is included in these annual numbers. I know that the number of people admitted to Desa Bina Diri, centers, which are limited to adults (19-59), rarely exceeds 400 persons annually. As I learned in previous years of research (Rusenko 2013), a disproportionate number of people in Desa Bina Diri have disabilities or mental illness, like the "rather like childish" man Azleena saw. Rescue totals also likely account for other people taken into custody by the Social Welfare Department—like single mothers, pregnant women, senior citizens, and children—and sent not to Desa Bina Diri but to specialized facilities for women, children, and the elderly. As Azleena noted, some people are arrested by immigration or police but these

\footnotetext{
${ }^{59}$ In 1965 the first rehabilitation camp was opened in Mersing, Johor. In 2005, a second was opened in Jerantut, Pahang. In the last 15 years three more have opened: one in Kucing, Sarawak, one in Sabah, and one outside of KL.
} 
numbers are probably neither included nor tabulated ${ }^{60}$. I often wonder whether numbers include people taken into custody and subsequently released, which is the vast majority. Given the spike to 4000 in 2017, I now more firmly believe they do.

The newer paradigm for managing homelessness emerged following the Ministry of Women's first homeless survey in KL in 2010, which identified approximately 1400 people sleeping rough in the capital. Shortly thereafter, the Prime Minister's Office and the Minister of Women matched resources ${ }^{61}$ to launch Malaysia’s first transitional shelter-and first alternate to the rescue system-in 2011: Anjung Singgah (Figure 8). This shelter has been limited to voluntary short-term stays and primarily aims to assist people seeking work. Additionally, it also accommodates people who can be transferred to civic or civic welfare institutions, but the limited capacity of such institutions keeps numbers low ${ }^{62}$.

Since 2010, interest in population counts has risen, such that the Town Planning Department at City Hall has taken up GIS mapping of "hotspots” throughout the capital (see Figure 9, page 175). In truth, this mode of collecting and organizing data borrows from data administration under the previous paradigm, used to plan courses for mass roundups. That is, previous generations of officers kept geographic record of where “destitute

\footnotetext{
${ }^{60}$ These numbers are not available. I believe these arrests are not included in annual rescue totals.

${ }^{61}$ Specify here amount of funding from PMO, and the Ministry of Women arranged for one of its own assets to be converted into a shelter, which would be administered by the National Welfare Foundation, a government-established quasi-governmental organization chaired by the Minister of Women.

62 This is generally limited to: orphans, women and children escaping domestic violence, people living with Aids, and some people with disabilities.
} 
persons” gathered to arrange caravans for taking them into custody. However, City

Hall's role in managing data appears new. One officer at the Ministry of Women's Policy

Division clarified in a 2019 interview $^{63}$ that the Federal Territories Ministry and its

subsidiary City Hall are "the one[s] with the resources and logistics" to manage mapping,

while the Ministry of Women was better prepared to concentrate on policy.

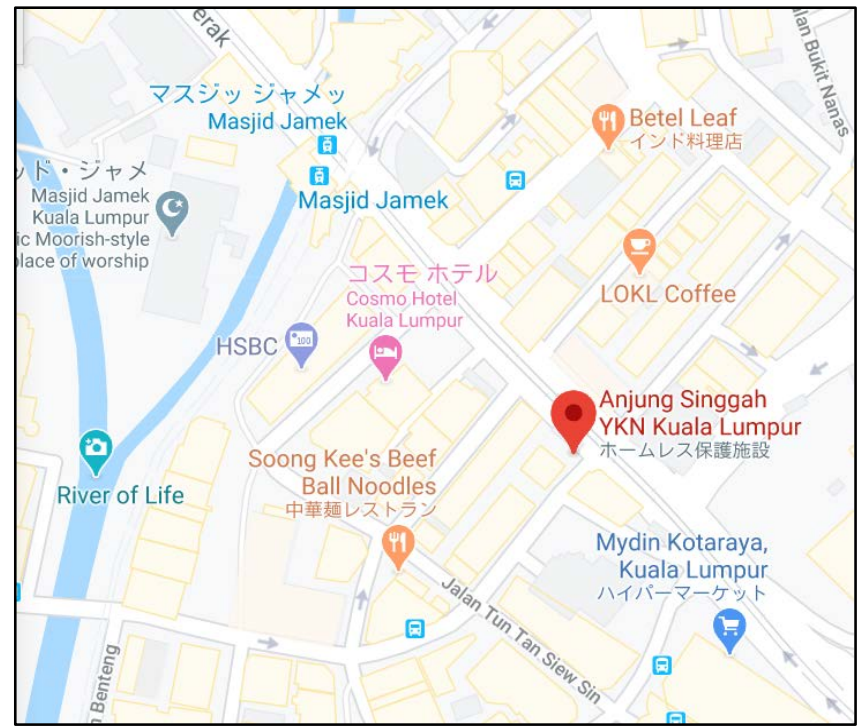

Figure 8. Google map showing Anjung Singgah on Hang Lekiu Street.

Note: Cahaya Suria (see Photos 6 \& 7) is on the opposite side of Mydin Kotaraya, approximately 300 meters or 4 minutes away.

Source: Google Maps

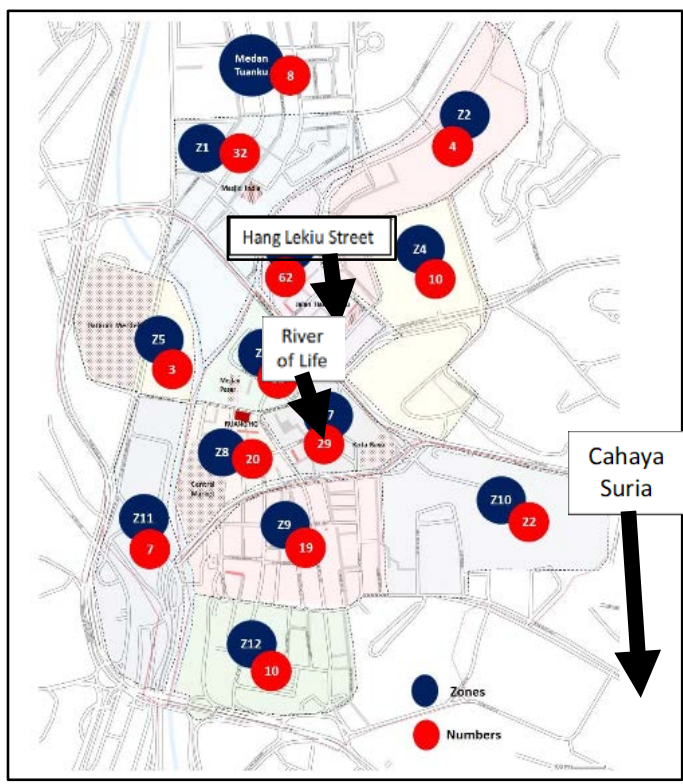

Figure 9. Map of KL Hotspots

Note: Numbers given in red reflect numbers of respondents to a Think City survey; They are not a population count. The locations however were provided by government. Source: Think City (2019:31)

When I returned to KL in 2019, I noticed that the spatial layout of areas

frequented by people experiencing homelessness had changed. I believe this traces in part to new institutional arrangements for shelter operations at Anjung Singgah; that is, rather than having NWF provide all meals and material aid through donations, as it had before,

${ }^{63}$ May 30, 2019 interview. 
a system of "integrating" CSOs was put in place. This system emerged as the federal government asked CSOs to provide assistance only when coordinating with governmentlinked facilities like Anjung Singgah, run by NWF under the Chairship of the Minister of Women (Photo 4). As mentioned earlier, CSOs that refused to cooperate were said to be at the root of litter and improperly distributed resources (Photo 5) As the integrated system took shape, Anjung Singgah also accommodated the wishes of CSOs wishing to distribute meals to people other than shelter residents. Thus, the shelter became a site for hundreds of people to come receive meals, services, and material aid on designated evenings. Consequently, this system brought more people to Hang Lekiu Street, now KL’s largest "hotspot" (see Figures 8 and 9, previous page).

Mohammad, a young Malaysian-Malay man in his 30s with repeated experience

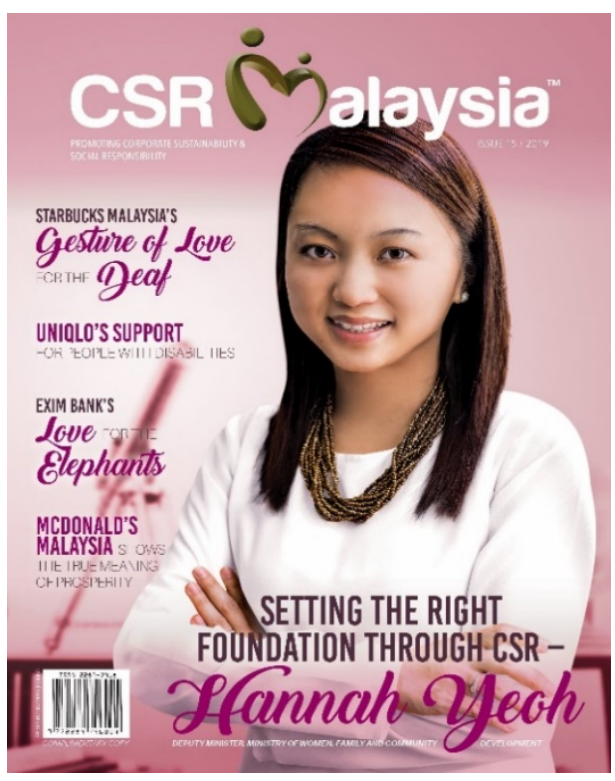

Photo 4. Malaysia's new Welfare Minister on the cover of CSR Malaysia.

Source: CSR Malaysia (2019)

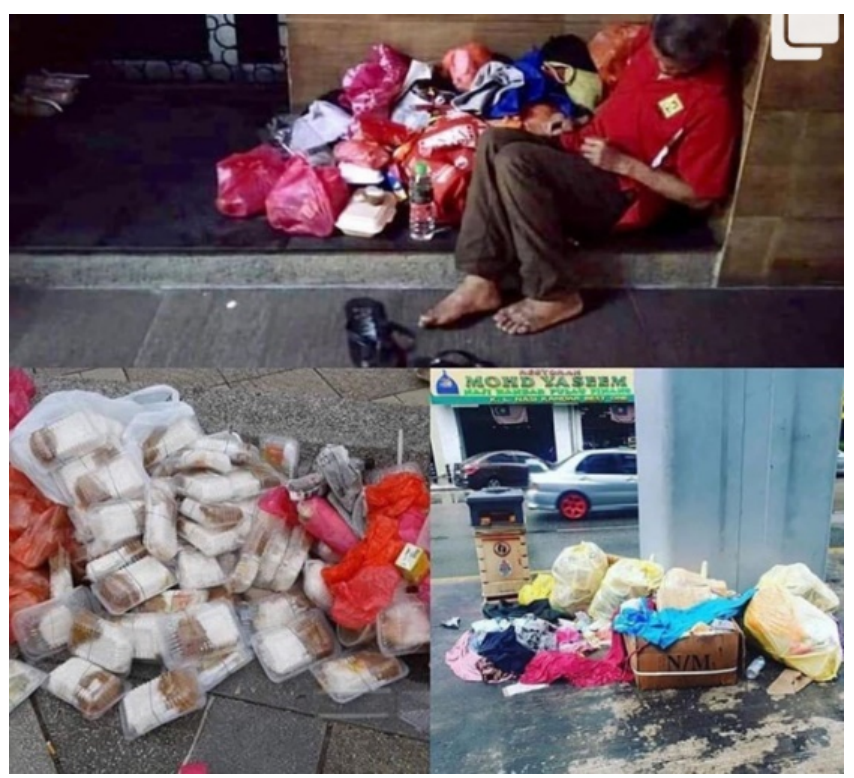

Photo 5. Photos used by media and government to shame CSOs. Source: New Straits Times (2019, May 21)

of homelessness and currently living in employer-provided accommodations—explained that the introduction and expansion of services alone does not explain the growth in 
hotspots. Rather, he notes, the spread of construction and redevelopment projects is also affecting the availability of space, as formerly open spaces are being privatized and/or developed. He explains that the pressure homeless people feel to relocate is not always explicitly targeting them.

Spaces are destroyed and rebuilt because of the development, lah ${ }^{64}$. Sometimes the place needs to change or upgrade. Sometimes it's not to displace the homeless. You see now [in Cahaya Suria Park], they can still sleep there [despite construction]. City Hall and the Social Welfare Department ask them to leave but they can still sleep.

He noted that the partial closure of Cahaya Suria (Photos 6 and 7; also Figure 9, page 175), a hotspot of five years prior, forced many people to seek new sleeping

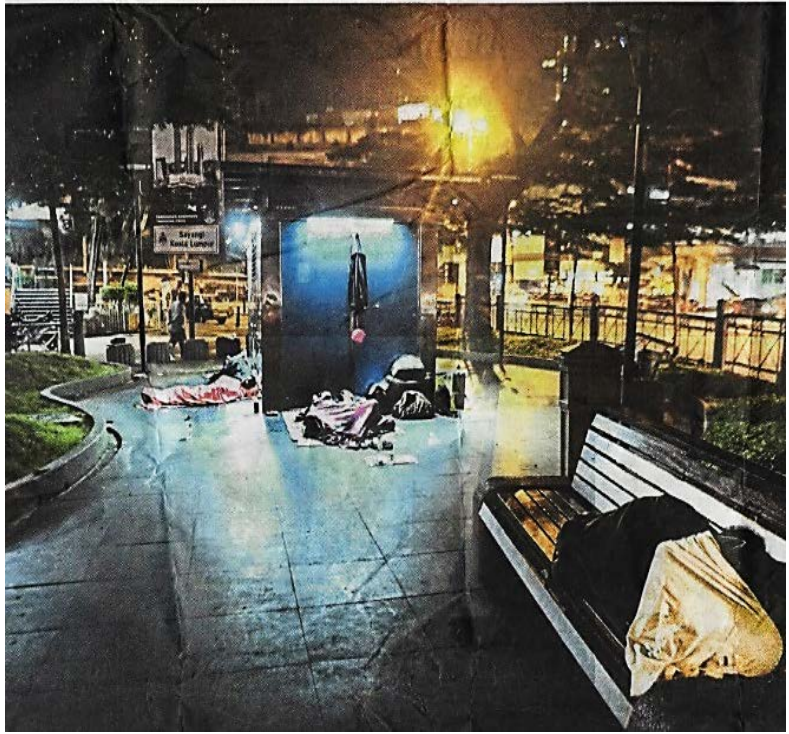

Photo 6. Cahaya Suria Park in 2014, when it was known as a hotspot.

Source: City After Night (2014)

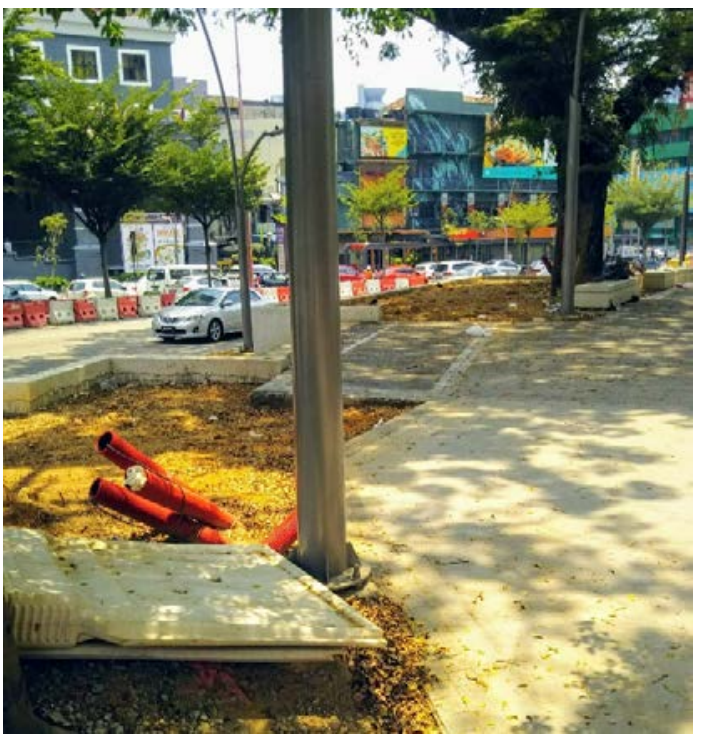

Photo 7. Cahaya Suria Park under construction in 2019. Chinatown can be seen in the background. (Photograph by author)

spaces, as did extended construction along KL's Klang River for the River of Life project. Hang Lekiu Street in 2014 had only about 10 people sleeping regularly in

64 “Lah” adds stress. It reads as if the word preceding it was italicized. 
the vicinity. However, development projects and the expansion of services at Anjung Singgah have led to over $1000 \%$ growth in numbers.

City Hall, which manages the two newer shelters, also relies on integrated CSOs for in-house meal provision and other activities including surveys and counts. The latest survey of persons sleeping rough in KL, conducted by Think City (2019), a government-linked think tank identifies approximately $80 \%$ of respondents as chronically homeless, defined as homeless for over one year, with 37\% homeless for over 6 years. Large open spaces in the capital have become valuable points for CSOs interested in providing aid to meet with potential clients, typically in locations near public transport (in consideration of volunteers and clients) and far from commercial districts (in consideration of City Hall). Increased interest in homelessness and the social value of charity and volunteer work has led to a concentration of activity in the Hang Lekiu Street area, owing in no small part to proximity to Anjung Singgah, which—in largely authoritarian Malaysiadenotes the government's blessings to civic actors interested in getting involved. While police regularly patrol Hang Lekiu Street and other hotspots at night, tourist spots are patrolled by City Hall during the day. Fazil described the purpose of the daytime patrols as being to protect Malaysia’s flourishing tourist industry. He explained that "tourists come between 10am and 4pm so City Hall lets us know that we should not be not be visible [at those times]". In a separate exchange with an officer from the 
Policy Planning Division of the Federal Territories Ministry, which guides City Hall, I was informed ${ }^{65}$ that these agencies are moving to the frontlines of policy because:

City Hall and the Federal Territories Ministry felt that there is an urgent need for our intervention... [because homelessness] carries with it serious ramifications to...Kuala Lumpur if left unchecked, most particularly with regards to the image of the capital city.

More specifically, City Hall and the Federal Territories Ministry, both non-welfare agencies, have taken the lead in intervening in homelessness to remedy what they identify as "discomfort and obstruction to businesses and other city dwellers". Such action is, in their view critical for fulfilling agency objectives of maintaining KL’s international image, particularly vis-à-vis tourism. When it comes to homelessness today, measures under welfare and public infrastructure agencies - the Ministry of Women and City Hall, respectively—are being modified and recalibrated, while policing alone appears to continue with minimal change.

New strategies and in/securities

—Site 1. TOKYO - Eviction: Where force advances, reason recedes

Not all of Tokyo's visible reductions in homelessness are attributable to patrols; there have also been repeated evictions since enactment of the 2002 Self-Reliance Support Act (see Aoki 2010; Sasanuma 2008) counter to its aim to "reintroduce sociallyexcluded persons like the homeless into society to actualize the spirit of the Constitution's Article 11 (Guaranteeing human rights) and Article 25 (Right to minimum standards of living)” (MHLW 2005). Government agencies have enacted several

${ }^{65}$ May 26, 2019 email correspondence. 
evictions under administrative subrogation, such as one in Miyashita Park in September 2010 and several in Koto Ward's Tatekawa Riverbed Park in 2011 and 2012. Other evictions, including one series of three evictions in Shibuya in June 2011, have been premised on the need for urgent infrastructural repairs, and thus use claims of public safety to override legal rights against eviction. More recently, the Olympics have provided public agencies with powerful rhetorical justification for initiating eviction, as evidenced in 2016 at Meiji Park where evictions forced not only park residents but also residents of nearby public housing ${ }^{66}$ (Inaba et al 2018) to make way for the construction of an IOC Headquarters.

Meiji Park’s tent residents spent months protesting the impending eviction, as did many in the public housing complex. Legally, the closure of Meiji Park would violate the Urban Parks Act as the municipal government had failed to establish an alternate park for evacuation purposes, as required. Consequently, encampment residents confronted officers sent to remove them regarding the state's audacity in violating its own laws while "you criticize us for supposedly violating ‘appropriate use’ statutes." (Orinpikku OidashiYamero 2016). Ultimately, the national government handed the project over to the Japan Sports Council, a quasi-governmental agency that used a temporary court order to evict residents. Today, evictees are suing the Japanese government, IOC, and JSC for unlawful eviction because—as one plaintiff, Fukui, says—other agencies might replicate this strategy if government "got a taste of success" ${ }^{\text {67 }}$. Fukui used the Japanese proverb,

\footnotetext{
${ }^{66}$ Ironically, public housing had been built as compensation for households who lost homes due to preparations for the 1964 Olympics.

${ }^{67}$ December 15, 2018 interview
} 
“Where force advances, reason recedes ${ }^{68 ”}$ to explain that the Olympics was accelerating change. As one witness to the Meiji Park eviction remarked, "the special exception [of the Olympics] has given the state opportunity to expand the limits of the law" (OurPlanet-TV 2016).

Over the last decade, rapid growth in the tourist industry in Asakusa around Sensōji Temple has led to commercial development in this historically working-class region, underdeveloped during Tokyo’s modern urbanization because of its historical association with poverty. Today, its antiquated aesthetic makes it popular as a tourist destination that contrasts Tokyo’s flashier regions. Moreover, redevelopment projects have crept into areas that people sleeping rough once freely congregated in including along Sumida River, one of the five areas targeted by the Transition-to-Community-Life Program. In late 2018, I learned that one man at Nishi-sando Arcade, located less than 200 meters from Asakusa’s Sensoji Temple, was appealing to local CSOs for help after police had come one rainy night to evacuate everyone sleeping in the arcade, which is unusual for the area.

I later went to the arcade with a CSO to learn more and met Taka, an ordinarily cheery man about 60 who stayed with a small clique of men who all earned money from public work and picking up odd jobs in Sanya. In an interview, he explained that officers had come multiple times and, each time, they woke everyone up by tapping their shoulders or banging on their cardboard and ordering them to, “Get up, get up!” When I asked him how they justified the clearance, he explained ${ }^{69}$,

\footnotetext{
${ }^{68}$ In Japanese, "Muri o tōseba dōri ga hikkomu".

${ }^{69}$ December 18, 2018 interview.
} 
Here, we are in a relatively weak position, so they don't need to say much. Sometimes they say that we can't sleep here. Each time, I ask, "Well then, where should I go?”... Once it was raining and an older man next to me had a cold, so I said, "You're asking us_-you're asking this sick man-to go out into the rain? Who will be responsible if his condition worsens, or if he dies? Will you take responsibility?!” But he said no.

Taka often recounted this story, usually in an agitated tone, when we would wait in the evening for police activity. Every time, he became very animated as he recalled defiantly confronting the officer while insisting, "Will you take responsibility?!” He seemed to be reclaiming his own importance after not being offered protection, or even consideration.

Despite repeated questioning by local activists and people like Taka who were forced to leave, the police never confirmed what legal foundation they believed justified their action. When I witnessed two such evacuations, the police insisted each time that they were acting — and justified in acting — on anonymous complaints. I tried pointing out that their actions violated multiple tenets of the 2002 Self-Reliance Act and 2018 national police orders (requiring police to honor the rights of homeless people and educate the public on those rights), but officers were firm in their stance that their obligation to the public to resolve complaints was platform enough. Specifically, I was told:

Officer: You do realize that if someone calls the police complaining that there is a problem, the police must take action, don't you?

Rayna: Yes, but there is no legal basis here...

Officer: The bigger issue here is not the legal technicalities but the fact that police officers cannot choose to not respond to a complaint. If we do not respond, people will wonder what it is we do. ${ }^{70}$

\footnotetext{
${ }^{70}$ February 9, 2019 observation. In Japanese, "Meiwaku dakara toiutsūhō ga areba keisatsu ga ugokanai to dame deshō. (Author: Tada hōtekina konkyō ga naito...) Hōritsu dōnokōno yori ha konkai ha tsuhō ga haitta kara nanimo shinai wake ni ha ikanai. Nanimo shinaide ireba tsūhō shite kita hito ga 'aa keisatsu ha nani o yatte irunda' toiu fūni nacchau. Sore, wakarimasu yone."
} 
Unlike other agencies, police officers emphasize a need for expedient results. However, this was accompanied by a presumption—visible across all agencies—-that disorder would be best corrected through unilateral action targeting "homeless persons".

—Site 2. KUALA LUMPUR - From Parens Patriae to Persuasion

In preparing for the 2017 SEA Games, the Ministry of Women arranged a twomonth "boot camp" for people sleeping rough in KL called Kem Pemantapan Jatidiri (Camp Get-Yourself-Together), located at a military training camp two hours from the capital. In an interview at the Ministry of Women’s Policy Division, one officer explained $^{71}$ that federal agencies wanted to clear the city, as it was customary to do so for major events using rescue operations. However, he also reassured me that "taking them away is not [like] locking them in a jail, because they have done nothing wrong." His pre-emptive explanation signaled to me his awareness of regularity of protest over DPA operations since 2014. Today, the Ministry is more careful about planning and justifying its actions.

To succeed with the two-month clearance in autumn 2017, the Ministry adopted three strategies. First, they developed plans for the camp with a "self-help" module incorporating skills training, health, and motivational courses as well as incentives in the form of an allowance (200RM) and a certificate, both received upon completion. The Ministry of Women's officer elaborated on the program design as follows.

The right thing to do is to expose them to certain skills or knowledge so that, we hope, within that 8 weeks they learn something, and they won't cause any trouble to anybody. Hopefully, they can become better and get a job that is

\footnotetext{
${ }^{71}$ May 30, 2019 interview.
} 
better. Or, if they want to connect with family, we assist them. If they don't want to do anything, we release them.

Second, the Ministry and the Welfare Department brought CSOs on board during planning stages by asking them to join the camp and distribute snacks, clothing, and other materials to participants. Lastly, they arranged for the camp to be voluntary. Persons who refused to participate were not forced to attend, as I confirmed through several interviews. However, pressure was nevertheless applied to maximize participation. Multiple rescue operations were conducted over the span of a few weeks "to persuade hundreds of homeless people in the capital to participate”, according to local newspapers (Bernama 2017). They counted approximately 200 participants.

Among people who declined to attend was Jaya, a Malaysian-Malay man in his early 70s, who has been living on the streets for much of the past two decades. He expressed ${ }^{72}$ frustration that agencies did not seem to have "a proper plan and program to address [homelessness or] a long-term solution”. He elaborated:

When they did the raid on us and they published it in the paper, they say, "We take these people and we train them." They [say they improve] our talents so one day we can stand on our own and return to a normal life. But actually, it is a lie. Some people were there for two months but they can only eat and sleep.... [Upon] release some received compensation... but this is not the way to manage people.

Jaya's frustration stems from his past experience with operations, which includes getting picked up multiple times over the last two decades and being detained in Desa Bini Diri in Sungai Buloh once. When I conducted research on operations in 2013, I learned through interviews that people with experience of being caught were most critical of

\footnotetext{
72 July 31, 2019 interview.
} 
interventions associating them with harassment or harm (such as sleep deprivation). Conversely, those without experience took the promise of "rescue" at face value, often assuming government would provide housing. However, even where people are critical of the interventions, few are critical of government agencies per se-or openly critical in interviews, at least. Instead, most clarify that the interventions—albeit detrimental to their interests—are evidence that government is trying to provide for them.

This practice of conducting mass arrests under a welfarist, rather than punitive, law was developed in the early 1960s under British parliamentary draftsman, J.S. Fiennes, who assisted in drafting Malaysia’s constitution. Between 1962 and 1965, he used his constitutional expertise to design the DPA's predecessor, the Vagrants Act to serve as a public order legislation that skirts constitutional rights to freedom of movement, on the one hand, and a social welfare legislation to justify a parens patriae (state-initiated) model of involuntary institutionalization, on the other. In practice today, this policy prioritizes neither detention nor rescue, but instead serves to manage the street-level visibility of homelessness.

Statistics show that even though only around 400 people are admitted to Desa Bina Diri each year, roundups affect growing numbers of people. That is, more people are being captured, interrogated, and released each year (see Table 5, page 171) for two purposes. One is to facilitate drug, immigration, and police arrests while conducting welfarist interventions under Social Welfare or, stated differently, to reduce the number of non-Malaysians, drug users, women, children, and persons with disabilities or mental or physical illness from the homeless population. The other is to compel people to leave the areas regularly patrolled, all generally located in the city center near commercial and 
tourist districts. In previous research, I learned that people who stayed in areas subject to operations were forced to either take on the financial burden of staying in restaurants or night-time accommodations, or the physical burden of stress and lower quality sleep (Rusenko 2013).

Even though roundups have been halted and the atmosphere at Hang Lekiu Street is more relaxed, people remain prone to interpreting certain events as indications of a coming raid. Once, I sat with Helmi and Badi at the center of Hang Lekiu Street, where a small lane cuts through the road and becomes a parking space where CSOs usually distribute materials. Badi was telling stories of his army service during Malaysia’s 2014 floods, when suddenly Helmi stood up and began packing his things. Surprised by the sudden movement, I asked Helmi what happened. He looked down at the ground and said very quietly under his breath, “That man’s a scout. I'm not sleeping here tonight.” Just 30 feet away in the parking area, one man in a red shirt was sitting on his motor bike and fiddling with his phone. I wouldn't have noticed otherwise, but once Helmi directed my attention to him, I agreed something seemed unnerving. Eventually, about eight people caught word of Helmi's concerns and left to sleep elsewhere that evening. There was no raid that night, but I was reminded that many, like Helmi, who’ve experienced seeing them—if not getting caught in them—do not yet feel fully at ease.

\section{Discussion}

Imperiality—or democracy in socio-spatial governance

Prior to the public sector's uptake of social work at the turn of the twentieth century, charitable organizations like Salvation Army single-handedly produced 
programs for addressing poverty, disseminated globally, including in Japan and Malaya. As the material and ideological basis of these organizations—along with their political legitimacy—were rooted in upper-class (imperialist capitalist) imperatives, they generally sought to remedy poverty in ways profitable to the transnational capitalist ambitions of the imperial state—and in the process made a transnational institution of themselves. Salvation Army in Japan, for example, developed programs in conjunction with both public- and private-sector actors designed to instill in the working classes the political, economic, and moral values of ruling/entrepreneurial classes. Such programs, it was argued, would eradicate poverty by creating people who created their own abundant wealth, thereby enriching all of society. As flawed as these assertions are-especially regarding the presumed failings of the working classes and the strengths of their benefactors—it is important to see them for their legacy: the direction of scrutiny in social programs. That is, systems are constructed based on a presumed need for top-down evaluation by enlightened classes—or compassionate actors_-rather than policy processes that would allow working classes to inform systems shaping their lives (Chapter 3). This structure insulates the false premises of such policies from critical bottom-up examination: an uneven relation that is part of imperial legacy.

By the time the state absorbed social work into public projects, compassionate actors remained gatekeepers in programs where they determined not only standards for eligibility, but also what resources would be distributed and what goals would be achieved—and how. History shows that over the next century (from the 1920s to the present) powers held by public-, private-, and civic-sector agents over policy targets have been used to various economic and political ends—some conventionally acceptable, and 
some not, but all determined for rather than with persons experiencing homelessness. The propagation of these relations through law and policy illustrate the salience of Agamben's (1998:53) Homo Sacer: a sacred being that can be killed by anyone but not sacrificed as, in life and death, "homo sacer is the one with respect to whom all [people] act as sovereigns”. That is, by identifying deficiencies within people as the root of homelessness and focus of policy imperatives of correction and care, public-, private-, and civic-sector organizations set in motion the need for scrutiny in the discretionary space that defines social work. Moreover, these presumed deficiencies underlie justification of a lack of checks and balances on discretionary agents by policy users. Hence, public officials within welfare, transportation, public infrastructure and other agencies are endowed with the paternalistic —and imperialistic — authority to make decisions determining the course of other people's lives.

Today, as over history, the aims and substance of public policies are largely determined by public and private sector actors with minimal if any consultation with, much less critical examination by, policy targets or users. The idea of centering the interests and wishes of people who, today, refuse a "one-room apartment" or do not pursue "good money" in Officers Tanaka and Harada's words, or people who otherwise “[need to] learn something, [so] they won’t cause any trouble”, according to the Ministry of Women's Policy Division officer has been met with resistance-even where, "they have done nothing wrong”. For this reason, historically and today, it is presumed that homelessness may only be addressed through the expertise of people who are not only "normal” but also instilled with the "appropriate” values, skills, and knowledge. In other words, as a social problem, homelessness has long been entrusted to—or even understood 
to be a burden of - the normative middle- and upper-classes, typically at the helm of public-, private-, and civic-sector organizations. For this reason, the interests and influence of the middle-class - as captured in CSO programs and protest as well as CSR projects—has shaped the direction of homelessness policy in both Japan and Malaysia, particularly since 1996 and 2014, respectively.

However, even though increased civic engagement has opened avenues to more compassionate measures over time, including housing-first programs and shelters featuring government-linked organizations like Yurin Association and NWF in prominent roles, the introduction of civic groups into policy processes alone does not necessarily improve decision-making or democratic governance—contrary even to promises popularly made by global institutions via initiatives like Local Agenda 21. Instead, these integrated multi-agentic projects—-to the extent that they are arranged through closed consultations, and particularly where exclusion of policy users in policy and political processes is not explicitly addressed—are wont to have profound de-democratizing effects. As agencies in both Tokyo and KL underscored, people experiencing homelessness tend to cause trouble and ought to be removed—or rescued—from public space, and rehabilitated through programs that lead them to "normal" life. Historically and today, the targets of various homelessness-related policies have been characterized as mismatched with modern society; Imperial logic dictates that they are not a part of modernity but have, instead, strayed from it. Such logic suggests that modern society itself is therefore perfected by their absence and fails to reckon with how it has produced—and been contingent on—-their presence. 
Compassion plays a key role in both cloaking and propagating the political marginalization of its objects. The global historical circuits by which social policies have been transmitted and produced have long held compassion to be a foundation for intervention. Imperialist benevolence at the turn of the twentieth century turned compassion into a global currency that led to the formal adoption of welfare- - a marker of civilized society—in post/imperial states like Japan, as well as narratives and systems of "rescue" and benevolent charity (rather than programmatic aid) in post/colonial states like Malaysia. Strictly speaking, while citizens of post/imperial states have been granted rights to minimal standards of living, those belonging to post/colonial states have been subject to the whims of benefactors. It is for this reason, perhaps, that people like Kei and Kenta respond with indignity as their standards (albeit outside of the scope of welfare) are rolled back, while many like Loh are "thankful to the government” for CSO meals. Similarly, these political differences likely underlie the prevalence of CSO interest in the restoration of rights, protections, and "minimal standards" for persons experiencing homelessness in Tokyo, evidenced in new laws and programs, as opposed to CSO interest in KL in offering care and comfort to the "less fortunate" by "feeding the needy", "empowering others", and taking up other causes that borrow from the rhetoric of international humanitarian organizations as they offer aid and services. Arendt's point about compassion as a political instrument, namely, that it necessitates suffering becomes clear when we consider the paradigms of policy. In either case, whether they are expressed through aims to reduce and eliminate homelessness, or rescue destitute people, homelessness is the foundation on which compassion is possible, and compassionate 
action is the foundation on which government agencies - and other compassionate actors-legitimate their authority.

In both Tokyo and KL, compassion for persons experiencing homelessness has indeed provided opportunity for a pivot by which civic, public, and private actors came together and brought resources to the table. However, state responsiveness to civic interest does not, on its own, make a democratic system. As prior chapters illustrate, democracy — by the grace of paternalism—-has long been deliberately limited through raced, classed, and otherwise differentiated categories of political rights. Here, the legacy of such governance manifests itself as parties largely insulated from homelessness debate and negotiate the liberties and needs of people who are most profoundly affected by it. Matters of policy are determined for particular people, but without those people, based on as-yet unexamined imperialist ideas that estimate their existence to be a public harmand their non-existence as the policy ideal/objective. Consequently, in Japan, while innovative housing programs emerge, so do new modes of anti-homeless urban engineering and policing via infrastructural agencies. Similarly, in Malaysia, while public and civic provision of shelters and aid have been mainstreamed, so have daytime patrols to reduce visibility of homelessness and begging. And, in both countries, NIMBY publics rail against CSO activities because the supposedly disorderly and overly generous support of CSOs is often said to exacerbate (if not cause) the problem.

Ultimately, public policy solutions are not solutions, because they fundamentally misunderstand the problem as existing outside of the normal workings of society and, hence, justify ideas and institutions that treat people in states of homelessness as needing 
enlightenment, rehabilitation, or rescue. That is, paternal—or imperialist—forms of compassion are premised on the reformation or rebirth of the other party, and require nothing in the way of reflection on one's relation to them. While action is certainly necessary, current actions fail because compassion—and its manifestation in policy— makes people experiencing homelessness the object, rather than the subject, of social change $^{73}$. The cynicism, as voiced by Jaya and Kei, that some people direct at public and civic services is both well-founded and astute, based as it is on their experience with the pitfalls and promise of normative care.

Socio-spatial security as a foundation of power

Social and spatial concerns are intertwined under capitalism, and global capitalism's concerns with people experiencing homelessness and public space have been no different, in law or practice. This is evidenced in not only the history of vagrancy laws in each city, but also in the welfarist measures that have underpinned concentrations of homelessness and poverty in certain districts, like Sanya in Tokyo and Jalan Pahang in $\mathrm{KL}^{74}$. As Japanese and Malaysian agencies began formally advancing urban redevelopment in the 1990s and 2000s, apparatuses of a social redevelopment also took shape- -in the form of innovative policies offering not only opportunities for (productive)

\footnotetext{
${ }^{73}$ This holds true in other realms where, for example, improving racist, sexist, and transphobic systems cannot be done without the lead of the most deeply affected parties.

${ }^{74}$ The same applies to Pusat Transit, Kuala Lumpur's low-threshold shelter located in the historically working-class Chow Kit district and across the street from the capital's General Hospital, formerly its Pauper Hospital.
} 
labor, but also adjusted avenues to accommodation—especially in Japan where productive labor is of relatively less value.

When applied in welfare states like Japan, neoliberal ideology transfers responsibility for human security from public systems to individuals as part of mechanisms for encouraging merit, efficiency, and incentive. In Japan, this has produced what Suzuki et al (2010) refer to as a "second modernity" of individualization, in which individuals—and particularly young generations and single person/parent households— experience enhanced insecurity in the face of reduced welfare income, public housing, labor regulation, and the like (Galaiou 2018; Hirayama 2013; Kingston 2012; Ogawa 2015; Shibata 2016; Shirahase 2014). At the same time, in Tokyo the effect on people experiencing homelessness has been a roll out of socio-spatial management through systems of meta-governance (Jessop 2007; Willse 2015) like the 2002 Homeless SelfReliance Support Act, which operationalizes multiple policy actors and fields. Although management began with Self-Reliance Centers, it progressively spilled into parks and streets from 2004. KL may follow a similar trajectory, too, once new homelessness regulation, currently under development at the Ministry of Women, is released. However, recent events in both cities, and their histories, suggest that compassionate engagement applied to the realm of socio-spatial regulation generates enhanced top-down, or paternalistic, control that manifests as micro-management of people experiencing homelessness and, especially in the case of KL, non-government-linked CSOs as well. 


\section{Conclusion}

With each era, compassionate actors are financed and re/produced through

processes that fail to reckon with, or remedy, power imbalances_-founded partly in systemic discrimination. Consequently, interventions propagate inequalities that are detrimental to both public good and public goods. For instance, the anti-homeless "hostile” design of benches—now common throughout Tokyo—offers little to no positive social or spatial impact, unless one prioritizes eliminating people’s physical presence above all else. Similarly, as has been argued in the past (Ministry of Welfare Services 1974), rescue operations are of "little positive help” in Kuala Lumpur because resources are concentrated in measures that, by turning a blind eye to the roots of poverty, fail to stall its onset. As long as programming is organized undemocratically in line with the whims and interests of agents who also, uncoincidentally, choose the metrics by which they are evaluated, new forms of homelessness policy offer little more than the status quo adapted to new capitalisms, new technologies, and new cultures and rhetorics.

In this connection, recent modes of delegating power to civil society—often through closed consultation-further unravels, rather than bolsters, democratic practice as it merely redistributes, rather than redresses, paternalistic powers. More vigilant sociospatial management cannot and will not offer greater socio-economic security; instead, it renders states of homelessness more repressive. In both cities, public-civic and publicprivate programs innovated through CSO cooperation include attributes that undermine people’s ability to survive unconditionally. Hence, what may appear to be democratization - and compassion-is opportunity for the state offer some control of the 
reins to limited private and civic actors, interested in leveraging their own power-albeit for altruistic aims in some cases. This offers an important opportunity to consider: to what degree do civil society organizations_-and each of us in civil society—share undemocratic power, and what do we gain? 


\section{CHAPTER 5. PINHANE}

\section{THE SQUEEZE OF CONTAINMENT AND CONTROL OF MOBILITY}

Introduction

Mobility took on new meaning in the late nineteenth century when technological changes accelerated capitalist industrialization, the expansion of imperialism and related ideas and institutions globally. In colonial and metropolitan societies alike, global capitalist systems created new avenues for geographic and social mobility as wealth offered opportunity to enhance social status, and geographic movement offered opportunity for wealth. Consequently, mobility became embedded in capitalist rhetoric, seen in discourse of self-advancement, that popularized capitalist principles of productivity, commercialism, resource exploitation, and consumerism as well as imperialist principles of enlightenment and scientific/intellectual practice.

As social and geographic mobility became more fluid in societies linked into global capitalism, public institutions for regulating the flow and distribution of economic resources and wealth became necessary. Initially police were central to social and spatial management as they protected mobile and immobile properties and directed uprooted people to the appropriate institutions in nineteenth century Tokyo (Chapter 3) and Kuala Lumpur (Chapter 2). Then, social infrastructure and related public agencies emerged around the turn of the twentieth century to facilitate the creation of a more enlightened social order capable of enhancing industrial production and coordinating re/distribution of wealth through less coercive means grounded in the ethos of "self-reliance” (Chapter 
4). Ultimately, state-run social programs and related institutions in the early twentieth century became the foundation for emergent public economies of care-thriving both because of need among the working classes and because of interest among middle- and upper-class agents in propagating enlightened culture, state benevolence, and ideas of “(self-)advancement” in colonies and metropoles alike.

Foucault (1998:137) refers to this shift as one marking the emergence of biopower, which 'exerts a positive influence on life [and] endeavors to administer, optimize, and multiply it, subjecting it to precise controls and comprehensive regulations”. While biopower, as envisioned by Foucault, addresses a transformation in governance occurring in metropoles—one that scales down repressive control and enhances caring, or benevolent, "positive influence on life"—a similar calculus of biopolitics was applied to European colonies including Malaya where British and Japanese experts also consulted with each other (Wellington 1927) as Japan made similar changes across its own metropole and colonial territories (Baxstrom 2000; Fujitani 2011; Lynteris 2011; Manderson 1999; Park 2014). Over this same span, as governments sought to "[locate] skilled and unskilled labor where it was most needed" (Wallis 1902:773) at the turn of the twentieth century, social policies were also calibrated to bolster and extend life in accordance with raced, classed, gendered, and abled systems of valuation—both within metropoles and across empires (i.e. globally- and locally-ordered stratification). Consequently, resulting systems effectively cultivated biopolitical divides between insured and non-insured lives, which also served as instruments of socio-spatial control (Duffield 2008). 
In this chapter, I explore how social policy systems and related institutions of welfare, labor, and care in Tokyo and Kuala Lumpur continue to be used in socio-spatial control today, based on interviews with people with first-hand experience of homelessness. In this connection, I introduce and discuss the concept of pinhane, or exploitation by bosses and brokers. Historically and today, the concept of pinhane has been widely used by people experiencing (and adjacent to) homelessness in Tokyo, but is also evident in narratives in Kuala Lumpur. In my discussion, I illustrate how pinhane reveals the foundation of socio-spatial control, i.e. uneven relations of power, or imperial formations, and why it exists. Ultimately, this chapter asks, how do socio-spatial controls inhibit exits from homelessness, and what advantages do they offer to non-homeless people?

Between a Rock and a Hard Place Japan

I was introduced to Keisuke by a coordinator for Tsukuroi Fund, a housing-first program run independently of recent metropolitan government pilot (2018-2019) programs. The coordinator had explained to me that Keisuke, a young athletic-looking man in his early 30s, had just moved from Tsukuroi’s transitional shelter into his own apartment one year prior. When I met Keisuke, we chatted for a few minutes before I asked about his experiences with Livelihood Protection. He explained ${ }^{75}$ somewhat selfconsciously that he had first visited a welfare office about ten years ago when he was sleeping in Shinjuku Central Park. He said that a man had approached him and asked

\footnotetext{
${ }^{75}$ January 4, 2019 interview.
} 
whether he would like a room at a privately-run facility near Tokyo. The man took Keisuke to a welfare office in Saitama where they filed his first application for Livelihood Protection. The facility had Keisuke settle in as soon as he arrived. The process took one month and, Keisuke noted, the facility directly handled all contact with the welfare office. Keisuke saw this as a relief because, as he explained, "I was sure the business would do what they needed to settle everything, like telling the office how much I needed help. I knew they’d stick up for me because they wanted me to stay.”

Keisuke also stated early in our interview that the business, unlike Tsukuroi, “pretty much did a trick (pinhane) on me for meals ${ }^{76 ”}$. From his overall monthly welfare allocation of approximately 120,000 yen (\$1100 USD), the facility provided him with a 500 yen (\$4.60) daily allowance and a 5000 yen (\$46) monthly supplement, or 20,000 yen (\$185) in cash. The facility was entitled to the remainder by way of a contract he signed in exchange for a private room, canteen meals, and utilities. On the other hand, Tsukuroi, which helped Keisuke locate his new apartment, takes none of his public benefits. ${ }^{77}$ Keisuke stayed only for a few months before he decided to leave-largely because of harassment he experienced from staff and residents. I asked if he had mentioned this harassment to the welfare office, and he responded that he was unable to broach it with them, explaining "it seemed like the business had some ties to the welfare office and so... I was scared. The facility would send us to the welfare office for appointments in their cars [so I knew people from the facility were there with

\footnotetext{
${ }^{76}$ In Japanese, "Shokuhi de kanzen pinhane sareta toiuka".

${ }^{77}$ The housing allowance from Keisuke's benefits was used to cover his stay in the transitional shelter. However, this portion of welfare assistance is as a rule transferred to landlords, rather than recipients.
} 
me.]...Therefore, I figured I just had to deal with it (the harassment), even if I was unhappy.”

After leaving the house in Saitama, Keisuke estimates he stayed in about 10 other facilities before finding his current apartment with Tsukuroi. As he talked about a decade of his experience, he described a process of acclimating, or acquiescing, to living conditions in the institutions he himself admits were hinkon bijinesu (lit. "poverty businesses"; companies that deliberately capitalize on homelessness and poverty). Keisuke said:

I'm grateful for what I had. I was able to eat... Around me, people would give lip to how bad the food was and how terrible things were, but I wasn't working so I figured I couldn’t complain. I learned how to live off [my allowance] and began to accept that this was all I had. I wasn't miserable.... Even though I didn't like it, I was grateful. I'd been homeless and knew I was better off indoors when it's raining.

His reflection offers a glimpse into his feelings regarding how "bad", "terrible”, "miserable", and "unhappy" his situation was—or not. His repeated attention to these elements over the course of our conversation seemed to underscore an underlying desire to retain optimism and shelter in the face of challenging circumstances. While he expresses gratitude for having an alternative to street homelessness, his inclination to feel gratitude also underscores the dearth of choice he perceives in his situation more generally. He went on to elaborate:

I had to go....I had only this option, and I wanted to make it work. I knew they were taking advantage of me but, still, I think I did a good job getting through it and coming this far... Even with everything I was [grateful for], though, I know now that I wasn't happy. [To be happy is] having freedom. To wake up and make your own breakfast and decide what to do for yourself. It's doing what you want with your time and your life. Some facility can't do that for us, it's something we do for ourselves. 
While Keisuke's stays at facilities across Tokyo, Saitama, and Aichi are evidence of his resilience and determination to stay housed, the housing itself did not resolve the economic, social, and even personal insecurities at the root of his troubles; these were, at best, suspended and, as Keisuke noted, reemerged periodically—often threatening his housed status. Because his root problems relating to family, addiction, and economic insecurity were not addressed, Keisuke explained that every time he left a facility, he would find himself back in Shinjuku Park. However, it was only after entering Tsukuroi, where life was less structured and enhanced by access to guidance and peer support, among other things, he experienced substantial progress. Ultimately, he attributes his happiness to having more control over his life.

As I spent more time in Shibuya and Sanya, I found that it was not unusual to hear people talk of spending time moving between multiple facilities to avoid the streets. In Ueno Park, I met Tetchan, a man in his early 70s—much older than Keisuke, who had spent the last six years moving between at least four hinkon bijinesu in Tokyo and Yokohama. He recalled—with indignity—-that the last facility he was in, in Chiba, had asked him to leave because he insisted on taking evening walks. He explained ${ }^{78}$ that the neighborhood had been hostile to the facility because it was known for bringing "homeless people" and he sensed early on that neighbors followed him with their eyes whenever he went out. Eventually complaints about his evening walks prompted the facility to ask that he stop and, when he refused, they had him leave for good. As he saw

\footnotetext{
${ }^{78}$ January 17, 2019 interview.
} 
it, there was no point in staying if it meant giving up certain things, and so he decided to go.

When I interviewed Toya, a former day laborer in his mid-70s sleeping rough in Sanya, he spoke at length about how hinkon bijinesu have multiplied as Livelihood Protection has become more accessible. He also expressed distaste—or maybe annoyance—at how facilities send agents to pick up clients from the streets, and how welfare offices turn to turn a blind eye to the problems inside. Over the last two decades, he says ${ }^{79}$, he has "been approached so many times...[by agents who] say there's no point in being on the street and I should consider welfare.” He remarked that, especially in the last ten years, people sleeping rough in Sanya have new attitudes around welfare: "it used to be that no one wanted it, and now it’s hard to find someone who doesn't!” He attributes this change to how "you never hear of people getting turned away anymore", which he himself found to be true. He explained that several years ago he went to the welfare office with some friends to ask about moving into a doya. However, they were told that only rooms at SSS were available so Toya refused because, as he says, he did not want to stay at a hinkon bijinesu. He added that some friends went but they "all ran away” within weeks. Toya says he’s not yet interested in going because he is skeptical: "Places like SSS constantly bring people in and put them on welfare, and welfare offices go along with anything because they keep rent costs down.” While these facilities may not keep rent costs down per se, Toya is right to note that welfare offices benefit from the

\footnotetext{
79 January 9, 2019 interview.
} 
use of these facilities as they reduce logistic trouble experienced by caseworkers—-known to carry heavy caseloads—in visiting numerous clients.

Daisuke, a man I met in Ueno Park in his early 40s, said that he became interested in Livelihood Protection when he first became homeless in 2010. He went on his own to the Sumida Ward welfare office but said that the officer at the front instructed him to enter a Self-Reliance Support Center. As he told his story ${ }^{80}$, he stressed his surprise that the public officer had arranged for his transportation before Daisuke could even ask for a welfare consultation. Daisuke succeeded in finding work at the Center and simultaneously secured a transitional apartment run by the metropolitan government. However, after one year, he decided to leave both the job and his apartment after conditions at work became unbearable for him. Before leaving, he had considered consulting with the welfare office so that he could keep the apartment but ultimately decided against it as he was unsure of whether he should trouble his caseworker and felt that he might have better chances if he returned to Tokyo anyway.

Near Sanya, I also spoke with three men who cycled between hanba, the SelfReliance Center, and earning money through public work and odd jobs while on the streets. One of them, Takeda, told $\mathrm{me}^{81}$ that he spent two years after first becoming homeless at a hanba after a labor broker approached him in Ueno Park to offer him a job. He said he was in his early 50s and had no experience in casual labor but, as hard as it was, he said he enjoyed learning working in construction. At the same time, though, his employer instituted wage penalties for poor performance, so that he earned less while he

\footnotetext{
80 January 17, 2019 interview.

${ }^{81}$ December 18, 2018 interview.
} 
was starting. In Shibuya, one woman in her late 30s told me about nearby cafes that young women in need of a place to stay, or money or food, would go. The cafes provide them with snacks and drinks for free and, in exchange, they are expected to talk to male customers. She said that while the cafes do not ask or in any way obligate women to leave with customers, some will—either with the right offer or without feasible alternatives.

I met Yanagi towards the end of my stay in Tokyo, walking home one winter evening at 8pm. I lived in an old apartment in a gentrifying neighborhood along Sumida River, just a 20-minute (1.5km) walk from the Sanya drop-in center. Each day, a mix of young families with strollers, sociable yet stern "grannies”, aging day laborers, and police officers crossed paths at the local park beside my neighborhood's library. I was walking in this direction on my way back from the supermarket, when I saw figures walking towards me in the dark. From a distance, they appeared to be two policemen half-carrying and half-dragging an elderly man by his arms towards the main road. I intuitively thought the man might be homeless based on how they manhandled him, and how they didn't allow him the dignity of fixing his pants, which were undone and falling. When I asked, the two officers insisted he was drunk, but Yanagi denied it. He said he did not feel well and that he wanted to go to a hospital, so we had the police call an ambulance.

Yanagi was hospitalized that evening at Kosei Central Hospital in Meguro, one of the few hospitals that readily accepts people known, or thought, to be homeless. Yanagi ended up staying nearly two months. He recovered almost fully in the first three weeks and then spent another three weeks waiting for the welfare office to process his release. As I visited, I slowly came to realize that the ward was dedicated to in-patient care for 
people who had been homeless. The visitor's log had only about four visits per weektwo being myself—despite a generally full ward of 30-40 men, all generally in their 60s and 70s, organized 5-6 persons to a room. Moreover, supervision seemed unusually stringent as staff kept an eye on all movement, and placed a heavy table lengthwise in front of the elevator to prevent patients from leaving without permission.

Two weeks after his recovery, Yanagi whispered to me that most men in the ward were generally recovered and healthy, and were merely biding time as the hospital received money for extending their stay. Based on this, and the fact that most beds in his room were empty, he thought his own release might be delayed, which it was. Over this time, however, his caseworker arranged for him to move into a doya in Arakawa where he could receive Livelihood Protection, according to his wishes. In fact, he stayed just across the street from where I first met him, near my apartment and the neighborhood's small police station.

Malaysia

In Kuala Lumpur, welfare assistance has improved in recent decades—in terms of accessibility, as seen in Tokyo, but also quantity ${ }^{82}$. However, the system remains piecemeal and limited in scope. On Hang Lekiu Street, I often met senior citizens who

\footnotetext{
${ }^{82}$ As civic movements have grown, along with a Malaysian middle class, Malaysia's welfare system has actually been beefed up slightly, albeit in a manner that underscores its piecemeal nature. For example, aid available to seniors, persons with disabilities, and single mothers was increased from RM100 to RM350RM400 between 1980 and 1990, when movements regarding these communities gained strength. In the subsequent decades, the number of people claiming these benefits has also increased. However, this economic aid cannot be claimed while homeless, although some people do collect through bank transfers set up prior to their homelessness.
} 
enrolled in elderly assistance ${ }^{83}$ (RM350 per month) and then pooled incomes to share partitioned rooms or SROs (approx. RM600 per month each) in the Chow Kit area. In 2012, the federal government began offering annual lump-sum benefits to people qualifying as low-income, amounting to RM250 for singles (RM400-500 in 2019) and RM500 for households (RM1000-1200 in 2019). In addition, the Federal Territories Islamic Religious Council (MAIWP) distributes through its offices baitulmal aid to Muslim (Muslim-born and convert) applicants, such as emergency aid for a maximum of RM50 two to four times per month and monthly aid similar to state welfare programs, e.g. for single mothers, seniors, and persons with disabilities. Importantly, however, doubling up on secular and Islamic welfare aid is strictly prohibited. Also, MAIWP has begun outreach services like meal distributions of its own in recent years. Nevertheless, welfare aid offered by the welfare department and MAIWP are neither available to all persons experiencing homelessness nor are they sufficient for exiting homelessness. Considering the sparse availability of financial aid, the introduction of three government-linked shelters and the upsurge in meal distributions by civic- and privatesector organizations has made remarkable impact. While I was on Hang Lekiu Street, I met no more than 3 or 4 people who had stayed in a shelter within the last year. Although this can be seen as unfortunate, it is not surprising. Research has shown that few people staying in shelters come from the streets ${ }^{84}$, and many people on the streets are skeptical of shelters. For instance, non-Malay Malaysians—or approximately $40-50 \%$ of the

\footnotetext{
${ }^{83}$ This can be quite difficult, as social workers may ask for letters and other evidence that children or relatives are unwilling to care for the applicant.

${ }^{84}$ Instead, most have been found to enter shelters to avoid street homelessness.
} 
homeless population (ThinkCity 2019) — generally tend to avoid government programs due to feelings that they will be sidelined in Malay-dominated government institutions ${ }^{85}$. Also, many people sleeping rough remain unconvinced that shelter services offer adequate, or unique, support. For instance, Kuala Lumpur’s shelters generally limit use to 2-8 week stays for people seeking employment, which tends to be insufficient for anyone not ready to almost immediately begin work. Also, people who are homeless and ready to start employment often already have access to information on jobs through social networks and contact with NGOs. Since many such jobs include accommodation at asrama (worker dormitories), one can technically find housing quickly regardless of whether one enters a shelter or not. During a tour of Pusat Transit, Kuala Lumpur's lowbarrier shelter launched in 2016, I learned that the facility limits its 200 beds to men who are seeking work or currently employed. Anjung Singgah, on the other hand, operates at a smaller capacity of two 40-bed rooms while referring men and women to employment, and, where possible, also connects senior citizens, children, and families to welfare homes or other assistance.

Asri, originally from East Malaysia, came to Kuala Lumpur to find work over a decade ago, and has been on the streets for about six years. He often works in construction, security, or other casual labor gigs in the daytime. In the evenings, he returns to his regular spot on Hang Lekiu Street where he and his friends congregate. The only times I have seen him lose his cool is when we talk about work, and his frustration

\footnotetext{
${ }^{85}$ This is based on racial quotas for civil service positions, instituted in 1970 and renewed in 1990 as a form of affirmative action to ensure Malays are no longer shut out from the modern political economy, as they were during the British colonial era.
} 
becomes apparent. During our interview, he explained ${ }^{86}$ this frustration as follows.

[At one company, sometimes] we wouldn't get paid, or our wages would be late, or we would work overtime with no compensation. And, when we complained, we were told that filing a report was useless because someone had connections to [police officers in] Bukit Aman. We were told it would be impossible to pursue so we should just let it be. They also said we were free to leave if we didn't want to work... It's maddening. 30 days pass and we get nothing. And then, the pay, when we get it, is so small. Like RM700 or RM800. You lose the will to work getting cheated like that. And there are so many cheats. It's exhausting.... Our work ethic would be better if we got paid, but we don't. We only get cheated and so we hate working these jobs ${ }^{87}$.

Asri’s experience underscores an important point: the abundance of low-skill jobs available to people experiencing homelessness is a source of anxiety, not relief, as is popularly assumed. The failure of public agencies to advocate improved labor protections and enforcement results in greater pressure on workers to vet employment opportunities and advocate for themselves even though decks are stacked against them. Pusat Transit and Anjung Singgah each have counselors that specialize in providing employment referrals, but neither has yet developed a system for better ensuring that clients are fairly compensated following hire ${ }^{88}$.

\footnotetext{
${ }^{86}$ July 1, 2019 interview.

${ }^{87}$ In Malay, "sangat sakitlah. kita orang orang susah ni, kalau 30 hari begitu rasa macam pecah kan kepala. Betul tak? Lagipun gaji bukan besar sangat. Paling banyak pun rm700, rm800 macam tu, so bila kena tipu lagi macam tu, rasa semangat untuk kerja. Terus terpadam macam tu, malas nak kerja lagi la. Taukeh banyak tipu macam tu kan, perasaan kita banyak fed up lah. Hate akan keluar. Benci tu akan keluar. Walaupun tad kita punya semangat pekerjaan lebih kuat kan untuk dapat gaji untuk mengubah hidup, tapi kalau kita kena tipu, kita akan benci pada pekerjaan tadi."

${ }^{88}$ I was informed by an officer with the Special Programs Department at the Federal Territories Ministry (responsible for Pusat Transit accommodations) that a blacklist system based on client complaints exists at present. This would at least prevent labor-sourcing to known violators, but processes for receiving and honoring complaints are not clear.
} 
Because government-linked shelters serve primarily as employment referral ${ }^{89}$ centers, it is easier to see why so few people who are already homeless access them. If employment itself is of dubious efficacy for improving one's situation, these shelters offer little in the way of aid. Older men who generally experience more difficulty in finding work see this as well. Rafi, a man in his late 60s with mixed Southeast Asian roots, explained ${ }^{90}$ his views as follows.

Anjung Singgah was created over political mileage.... Corruption has been a culture or, really, the culture of this country. To do business in Malaysia, it doesn't matter who you are. It matters who you know. [Anjung Singgah] is something they created so that these people [who are homeless] will become normal. But... to me this is all rubbish. It's a failure... [because] they (government officers) never study. It is just for their political mileage.

Rafi also sees the boom in CSO visibility—and especially meal provision—similarly.

[Among CSOs, there are] two categories: one getting funding from the government and the other getting funds from the company that has corporate responsibility....So now... someone [at these CSOs] is making money... Some just give [us] simple food and make so much money... I [heard CSOs receive] 20 ringgit [to produce each packet but] what are we getting? It is a chicken so small and rice, which isn't a lot of money. Where does [that money] go? [My friend] says they claim for the staff. Logistically or blah blah blah blah blah. So, if that's the case... might as well let [us] line up and give [us] the RM20. Or maybe 15, or 10.

I have not yet confirmed whether CSOs receive funding from government for providing food. However, CSOs and government-linked organizations ${ }^{91}$ absolutely do receive private financial donations in support of their programs, including meal distributions. Similarly, linkups between CSOs and private businesses, when reported in media typically benefit both parties. Rafi's insight is valuable because it illuminates how

\footnotetext{
${ }^{89}$ Although they may also refer clients to other government services, albeit limited, such as private or civic shelters for seniors, women, and OKU or public housing for families.

${ }^{90}$ April 24, 2019 interview.

${ }^{91}$ Like the National Welfare Foundation, which runs Anjung Singgah.
} 
he views the political economy that is not only built upon circumstances of homelessness, but also designed to largely bypass people experiencing homelessness. He captures this view by stressing that people like himself would benefit more if only meal distributions were substituted with cash. This point, moreover, also calls into question time spent on debating, critiquing, and praising CSO activity like meal distributions, when people experiencing homelessness never explicitly asked for, much less demanded, them. Scrutiny of these activities rarely, if ever, involves their point of view.

At Hang Lekiu Street, I did not precisely count the number of people I met who had been caught in rescue operations, but there were tens of them—and most noted that they were simply released, like Azleena, after being questioned and drug tested. I also met a handful of people who had spent time in the DBD holding center at Sungai Buloh ${ }^{92}$ and/or the 2017 SEA Games boot camp. However, over the course of six months, although I heard a lot of talk about what people had heard of the DBD rehabilitation centers in Mersing and Jerantut, I only met two people who had spent time there. One was Sim, a young Malaysian-Chinese man with an intellectual disability in his early 40s, and the other was Zali, a Malaysian-Malay man in his early 50s with schizophrenia. Both men described their stays as traumatizing, especially Zali who generally refused to talk about it with anyone, and both had made an escape after staying for two years in the three-year program.

\footnotetext{
${ }^{92}$ People caught by welfare officers in rescue operations are, at the discretion of caseworkers and, then, by order of a magistrate, sent to Desa Bina Diri (DBD; by law, for persons aged 18-59) for a 3-year rehabilitation program, or Rumah Seri Kenangan (RSK; by law, for persons 60 and above) permanently. Until the magistrate's order is obtained, people may be held in Sugai Buloh (or an RSK facility in states beyond Selangor) for up to a month as social welfare officers investigate the background of inmates and produce a report).
} 
Stigma surrounding mental illness in Malaysia is far-reaching and breeds fearespecially where it is discussed in conjunction with homelessness. As a result, people managing mental health conditions while homeless have to contend with a lot of stress. At the same time, because Malaysia's health care system allows for people without income to receive free medical care at public clinics and hospitals, many people like Zali and our common friend Asmawati could regularly visit and consult with doctors or specialists, as necessary, and continue prescriptions. Zali, in particular, seemed comfortable disclosing and discussing mental health, including his feelings about medication, which he preferred to not take. He and Asmawati, and some other people I met, were comfortable discussing mental health, doctors, and medication openly with me and their circle of friends. However, I also met several women and men in their 20s, 30s, and 40s who became isolated because of anxiety around seeking help and fear that they would not have and social support from friends if they shared.

I met Zali at Hang Lekiu Street where he would come to socialize and eat. A friend of his recommended I talk to him as I was expressing interest in Desa Bina Diri. Zali told me that he had spent nearly three years in Mersing but eventually ran off one night. I asked a little about what the facility was like, but he declined to share for the most part. He offered a little insight into his distress at having to live with bedbugs and receiving rotten food. He also mentioned being upset by seeing people restrained. Later, during my own visit to Mersing in July 2019, I saw conditions at the facility—originally built in 1965 and largely in the same archaic condition—-that verify his experience likely was, and remains, common. Sim, on the other hand, had been sent to Jerantut, which was built in 2006 —40 years after Mersing. Consequently, Jerantut's facilities—whether 
medical rooms, dormitory rooms, bathing spaces, dining infrastructure, and so on—were a stark contrast to, and fortunate upgrade from, what Zali had known. I understood why Sim reported ${ }^{93}$ being unhappy with the bedbugs but nothing else in terms of infrastructure. According to him, each day was almost pleasant. He started with breakfast in the cafeteria, and chatted with friends until he would be sent to work in a garden. Then, everyone would have lunch and spend afternoons entertaining visitors from charity or school groups. Lastly, after dinner, they would watch TV before retiring. After two years, he decided to leave because his stay was affecting him emotionally.

Rayna: "Did you tell the staff before you left?"

Sim: "No. I run away. ... I don't know what happened. For two years, I was very far. I was very tired. I felt not well. After I come back to KL, I was not well also. My friends say, why did you run away? I said I was not well. I could not do anything."

"When did you run away?"

"No one could see. In the night time. I was scared."

"There is no fence?"

"Got."

"So you climbed?"

(Nods.) "Dangerous."

"Then you walked to Kuala Lumpur?"

(Shakes head.) "People give me money so I buy the ticket to come."

Like Zali, Sim was doing well for himself when I met him. He stayed by a bridge with about four other men and had multiple friends at Jalan Hang Lekiu. After we talked about Jerantut, I asked Sim what he thought the government should do for people in his situation.

\footnotetext{
${ }^{93}$ May 4, 2019 interview.
} 
"I want money," he answered. "No money, cannot do anything. Not well." "With money, you can find a place to stay?” I asked.

"Anywhere can. Hotel can. I can buy anything. No money, cannot do anything. [Having money is] better."

"You mean better than Jerantut?"

"Yeah."

Pinhane

The expression “pinhane” has been used by day laborers in Japan since at least the mid-twentieth century. It refers to wage stealing by labor brokers and other middlemen — typically through debts, fees, or other forms of wage cuts — effectively trapping or squeezing workers at their place of employment. Exploitative practices such as these were rampant throughout Japan over the course of early industrialization and imperial expansion, particularly in mining, manufacturing, and other industries that relied on disproportionately burakumin, indigenous, female, colonial (e.g. Taiwanese, Korean, Chinese, etc.), or other globally and locally marginalized labor forces. In recent decades, the expression pinhane — still in use-often emerges as people discuss their experiences with Livelihood Protection, just as Keisuke did when he said that businesses "pretty much did a trick (pinhane) on me for meals”. These hinkon bijinesu have proliferated in Japan by offering accommodations, not unlike shelters or SROs, for people experiencing homelessness and claiming or facilitating Livelihood Protection on behalf of their clients, in exchange. These businesses specifically target people who would otherwise experience difficulty in receiving assistance owing to scrutiny by welfare officers.

Although yoseba are no longer serve as a central space for brokers or middlemen to find workers, casual laborers in Japan continue to experience pinhane via today's 
hanba ${ }^{94}$ systems and the emergence of haken (lit. dispatch) brokers. Moreover, just as labor brokers and middlemen profited over the course of industrialization by capitalizing on the housing and economic insecurity of their laborers through finder's fees, accommodation fees, and other charges, hinkon bijinesu in Japan’s post-industrial service-based economy saddle people mired in identical insecurities with overblown fees for meals, utilities, and other managerial costs. For this reason, use of the concept pinhane in the context of poverty businesses seems to naturally extend from its history in the industrial-era yoseba. Moreover, in both contexts, conditions of exploitation tend to be regularly, often systematically, overlooked by the state as long as the marginalized groups targeted by middle-men are channeled into industries propping up the economy and, thus, "integrated" into the ideal social order.

The expression pinhane necessarily captures two entangled sentiments: of being constrained (or “caught”) and exploited. It communicates the speaker's frustration at having little to no alternative—and this lack of alternatives being used against them. This practice — and experience—is not limited to Japan; Asri referred to it as he complained, “They...said we were free to leave if we didn’t want to work... It’s maddening”. I first heard of pinhane in reference to homelessness in 2001 in Suginami Ward, located far from the yoseba, where local CSO volunteers active in helping people enroll in Livelihood Protection would warn each other of SSS, an accommodation services organization known to practice pinhane. That is, as Keisuke described, where welfare recipients received $\$ 1400$ per month, SSS would keep all but $\$ 100-200$ to cover rent,

\footnotetext{
${ }^{94}$ Hanba are employer-provided accommodations_-also dating back to the Meiji era (1868-1912) that operate as spaces where employers exploit both the productive capacity and reproductive needs of laborers.
} 
food, and utilities—-thereby charging well above the market rate for facilities that are made even more profitable by under-serving clients. For instance, Keisuke had described how facilities would cut costs by doubling people up in dormitory-style rooms, serving instant noodles as a meal, and assigning mandatory chores (to save on cleaning costs).

The term hinkon bijinesu has become widely known in Japan as facilities like these have mushroomed over the last two decades. The term is often associated with incidents of exploitation or abuse that make the news. For instance, in March 2017 the Saitama district court awarded two men—both of whom were scouted by brokers in public spaces-approximately $\$ 150,000$ in compensation for living conditions they were subjected to at a hinkon bijinesu (Saitama Sōgō Hōritsu Jimusho 2017), and that same year one woman died as a result of abuse by a facility director in Ichikawa (Resident at Ichikawa Welfare Facility Dies 2017). While some cases are widely publicized and thus legitimated through public and even judicial scrutiny, countless instances of harassment or trouble are also conveyed widely through social (and "whisper") networks that people like Toya and CSOs volunteers rely on when considering Livelihood Protection and accommodation providers. CSOs and welfare users have pushed for greater regulation of accommodation providers since the early 2000s, but public agencies have dragged their heels. As a result, many potential users like Toya, pause at the idea of welfare and/or entering housing. In this regard, the "chronic" nature of chronic homelessness ought to be more readily understood as fundamentally indicative of the failure of public and private agencies to deliver acceptable levels of aid and services. However, narratives surrounding homelessness prompt the public, including public officers, to misrecognize the problem 
as rooted in individuals who have no interest in housing or help but are, instead, hooked on homelessness.

People faced with exploitation and/or abuse at facilities often feel they have little choice but to discontinue their stays. This is particularly true where, like Keisuke, facility residents are dissuaded or fearful of reporting problems because government agencies appear visibly aligned with service providers. Moreover, exiting accommodations like Keisuke without notifying or making pertinent arrangements with caseworkers effectively results in the termination of livelihood protection, recorded as termination due to “disappearance”. While numbers of "disappearances” vary across Japan, they are often substantial proportion of all terminations, generally ranging between $10-40 \%$ nationally ${ }^{95}$. CSOs and legal professionals (i.e. Tokyo Bar Association 2016) have called attention to how inaction by caseworkers and public agencies regarding "disappearances" not only fails the immediate interests of welfare users (whose access to welfare should, for example, be reinstituted in many cases), but also systematically undermines the capacity of the overall welfare system to ensure human rights and securities.

In Malaysia, too, pinhane-type practices have existed since as far back as the early nineteenth century, although varying in character and name according to whether they fell under British, Indian, Chinese, Japanese, or post-independence Malaysian systems of labor recruitment. As in Japan, the deliberate squeezing of laborers at global capitalism's margins led to disproportionate homelessness among these laborers (e.g. yoseba laborers in Japan, and "coolie” and plantation laborers in Malaya/Malaysia) since

\footnotetext{
${ }^{95}$ As seen in ward and prefectural level data from 2008-2016.
} 
the nineteenth century. To the present day, labor, land, and commodities in Malaysia, unlike those in welfare states like Japan, have remained in largely unregulated and underregulated shadow zones ${ }^{96}$. These informal markets have-historically and todayfunctioned as a blessing and a curse for people like Azleena, Asri, and most everyone I met at Hang Lekiu Street. That is, the informal sector serves as a buffer zone enabling many to earn an income or access goods ${ }^{97}$, such as through sex work, participation in pasar karat (black market vending), and some forms of casual labor-but such markets are necessarily rife with abuse and exploitation, some of which constitute-as Asri noted - the "maddening" experience of pinhane.

Offering uplift_-or constraining mobility?

In Kuala Lumpur, like Tokyo, as service industries have come to dominate the economy, new methods of pinhane have emerged alongside growing demand for unskilled labor in security, food and beverage, hotel, and construction industries. People experiencing homelessness — especially those under 40-are systematically channeled into these positions through labor brokers and scouts who recruit by approaching people in public spaces, asking CSOs to refer people looking for work, and even working with government-linked shelters to advertise jobs, often with employer-provided accommodation. Many people, like Asri, entering these kinds of positions find that their wages are withheld or reduced, or that living conditions become unbearable. For

\footnotetext{
96 This is not to say informal markets do not exist in Japan. As the cases of Takeda and unnamed women in Shibuya show, informal markets are a lifeline for people globally, but their scope relative to formal markets is much larger in so-called Third World countries.

${ }^{97}$ In many places informal markets can be used to even procure land, but not in KL.
} 
example, limited data available on employment referrals at Anjung Singgah shows that a majority of shelter clients receiving placements felt compelled to leave new jobs within the first year, if not within weeks or months (Rusenko 2014).

The income and housing insecurity and poor labor conditions usually intrinsic to low-wage work available through these programs are not often independently identified or addressed within homelessness policy as problematic; not at least to the same degree that refusal on the part of policy users to accept such work is. Despite high turnover rates, evident since 2011, government and government-linked agencies in KL have not instituted processes for systematically following up on clients placed to verify conditions of labor and accommodation. Similarly, Tokyo metropolitan agencies tout high placement rates in service-sector and manufacturing jobs as evidence that Self-Reliance Support Centers help upwards of 50\% of entrants exit or avoid homelessness ${ }^{98}$, while being less transparent around data on turnover. In this way, government agencies and civic groups either actively propagate or passively reinforce popular narratives that high turnover and low uptake rates related to such jobs are rooted in policy users’ laziness, lack of motivation, and dependency on public compassion and free meals. In both cities, the public misrecognizes homelessness as rooted in people who are "hooked" on homelessness and therefore eschew policy solutions like housing or income. Rarely is there serious consideration of even the possibility of problems inherent to policy, or policy-linked institutions.

\footnotetext{
${ }^{98}$ Yuji Yamada, Self-Reliance Support Administrator at the Bureau of Social Welfare and Public Health, Tokyo Metropolitan Government, Interview and email correspondence, November 23, 2018
} 
Narratives used to attribute policy failure to users are based on unspoken assumptions that people in states of homelessness are resistant to social values and norms presumably adopted by people who are not. In postindustrial Japan, for example, these values and norms dictate that people ought to enter Self-Reliance Support Centers wherever they (like Daisuke) may exit homelessness by finding employment—or they ought to embrace Livelihood Protection and, where need be, residence in welfare facilities if not (like Toya). In contemporary Malaysia, people are expected to find work, like Asri, or enter transitional shelters to receive referrals where additional support is needed. Additionally, DBD and RSK facilities exist to care for people who are unable to support themselves or receive support from family. In both Japan and Malaysia, people who defy these expectations or policy solutions — and especially those classified as “chronically” homeless—are presumed to be incompatible with—or resistant to—-modern society, including the material relief and security it provides.

Ultimately, however, these channels to labor and channels to care meet with resistance because they offer little in the way of socio-economic uplift or stability. More attention ought to be paid to the actual material in/security and conditions of life that people are subjected to when enrolled in programs designed to resolve homelessness. The prevalence of cyclical experiences of homelessness among people who have used policy—such as Tetchan, Keisuke, Rafi, and Sim—speaks volumes about socioeconomic immobility that programming generally reinforces. Here, pinhane plays a central role. That is, more often than not, the quality of jobs and accommodation as well as the economic and existential security granted to people through policy are all a far cry from what would be deemed adequate for people if they had not been recently assigned to 
the particular category of "homeless person". While these labor and living conditions, as well as the dignity that is denied to people by such disparities, are in and of themselves problematic, I wish to emphasize that, here in this context, they are created under and through the powers and authority of policy. This gap—and the failure of policy to ensure even a floor for "minimal standards of living" —one that would at least prohibit exploitation and abuse—is keenly recognized by people who have chosen to avoid public programs like Toya and Asri.

Over ten years spent in about ten facilities, Keisuke learned that "I had only this option, and I wanted to make it work”. Therefore, he accommodated to life in welfare facilities like SSS as best as he could. Even still, he often found himself returning to the proverbial "square one" in Shinjuku Park, due to conditions at facilities that were difficult to tolerate, on the one hand, and his limited set of options, on the other. The same applies to Zali and Sim, who stayed for years at government-prescribed programs In Jerantut and Mersing, before deciding to escape and return to KL. Toya and Rafi have avoided government-linked programs and manage as best as they can, while sleeping on the street or at employer-provided accommodation.

While policy solutions in both KL and Tokyo offer opportunities that some people choose to—or, in the case of Zali and Sim, had to—accept, these programs are not the sweeping equalizers many non-homeless people believe them to be. In both cities, policies and programs profoundly constrain the options of people grappling with homelessness. Consequently, people develop a sense of the limits of their own social and geographic mobility owing to insecurities in employment, income, and housing. The gap that exists between what is granted to policy users versus what comprises actual social 
norms for material comfort and security is typically justified in rhetoric of individuals needing to "earn" their status—and/or being given anything is still better than nothing (i.e. “beggars can’t be choosers”). However, for many, the conditions endemic to entering institutions of labor or care represent not a benefit (i.e. a "step up") but a risk, as their conditions fail to improve, which in and of itself (even barring outright exploitation or abuse) places a squeeze on policy users. This squeeze is not rooted in policy users' incapacity, but in the risks and harms of policy itself.

The welfarist aims of social policies, as shown over the last 150 years of modern development, has effectively channeled individuals into corrective and compassionate spaces meant to uplift, enlighten, reform, rehabilitate, and reintegrate people so that they may be recognized as "normal”, or fully human. Ironically, although compassionate actors argue that their objectives are inclusionary, policies governing street homelessness are necessarily exclusionary. Socially and economically, policy users are granted only marginal benefit—often in the form of low wages and less stigmatized (but not unstigmatized) existence. Moreover, without social or economic resources of their own, people generally remain reliant on public- and private-sector actors for legitimized access to these. Spatial movement does open up new opportunity, but until one has access to social and economic resources, one's options are extremely constrained. That is, because access to public space—and therefore mobility—is intrinsically limited by rules around the use of public and private property (Waldron 1992), mobility is also reliant on privateand public-sector actors (or bosses, brokers, and policy agents). Consequently, welfarist policies become fertile ground for pinhane practices as policy users—by virtue of their lack of resources-have little to no greater choice than whether to accept terms offered, 
or walk away, as noted by Keisuke and Asri. This squeeze deliberately plays with the social and economic limits of some people's survival for the benefit, or profit of others. More specifically, it serves as a basis for the social and economic power of private and civic sector actors involved in policy interventions, as I cover in the next section.

Mobilizing the middle and upper classes

As covered in the last chapter, while civil society often views the rise of civic action—such as meal distribution and housing-first programs—as a win that brings government "closer to the people" — and people closer to government, the integration of CSOs into policy processes does not, on its own, necessarily have a democratizing effect. As the experiences of Rafi, Toya, and other interviewees illustrate, policy users in institutions of care and labor have few if any avenues to influence or control policy outcomes, other than "mak[ing] it work", as Keisuke says ${ }^{99}$. Visible increases in these institutions in both countries are accompanied by policies that skirt matters of accountability with regard to policy failure-most evident in the outsourcing of programs—in part or as a whole—-to civic and private actors like NWF and SSS, thus undercutting processes for systematically addressing micro and macro issues at the root of homelessness.

For example, protest against eviction and CSO-based demands for expanded aid led to new policy approaches in Tokyo—including Self-Reliance Support Centers and, eventually, greater access to Livelihood Protection and housing. Similarly, public protests

\footnotetext{
${ }^{99}$ This is an important point for the Japanese context, considering the integral role that CSOs have played in policy formation and implementation for over two decades already.
} 
against roundups and CSO-based demands for the expansion of aid in Kuala Lumpur also led to new policy approaches_-including employment referrals, transitional shelters, and free meals and other services. However, in both cities, the greatest beneficiaries of such systems are private and public sector actors who gain politically and economically not only from public order measures, which effectively underwrite redevelopment, but also from social measures such as employment referrals and housing programs—visible in the proliferation of exploitation: either in street-level care like meal distribution and material aid (Chapter 4), or pinhane by labor brokers and hinkon bijinesu (arguably engulfing, as seen in Yanagi's case, medical care providers). To the extent that policy users are denied influence or control over policy outcomes, public order and social measures alike act as a wedge against their interests.

In each city, private- and civic-sector actors are capitalizing not only on economic opportunity, as referenced above, but also political interest and cultural currency related to engagement. While these policies also offer material and social benefit to persons experiencing homelessness, there are also limitations systematically placed on benefits granted to clients and service users-limitations that are not so rigorously limited or enforced for benefactors and service providers. Thus, the construction of policy tends to benefit actors with economic and political influence over operations. Employers, for one, gain new channels for readily procuring labor, arguably reducing the need to improve labor conditions or otherwise prevent turnover. Stated differently, because high turnover rates can benefit employers by keeping labor costs down, they are not generally addressed as a policy problem until employers' interests are threatened. 
Similarly, public agencies also benefit politically and economically from programs, primarily in how they help to achieve an "orderly" city by placing people in employment and accommodation, even if only tentatively as Anjung Singgah and SelfReliance Support Centers have both shown. Insecurities impacting users are generally not addressed until their inefficacy or even failure can be traced to public- or private-sector agencies, which occurs only rarely. For instance, historically and today, employerprovided accommodations including Japan's hanba, and Malaysia's asrama, have been utilized by public agencies to resolve homelessness and unemployment in one fell swoop. Sometimes problems traced to an employer will result in blacklisting of that employer from public programs, but the overall system will remain the same, largely owing to what would otherwise appear to be its success in channeling people to employment.

However, from the view of individuals seeking income or shelter, employerprovided accommodation is the most insecure of possible options. This is not only because one is prone to losing both as quickly as they were gained, but also because such conditions expand opportunity for pinhane, or profiteering through exploitation. Just as public agencies have failed to bring an end to pinhane as it occurred in hanba over Japan's modern history, little is being done to address hinkon bijinesu, or pinhane as experienced today. The recent shift towards the provision of housing in Tokyo, and shelter in Kuala Lumpur, has created greater opportunity for private- and civic-sector groups to build new economies premised on labor, welfare, housing, and care (e.g. meal distributions) that are, indeed, founded on fundamental social and economic insecurities underlying homelessness. In this regard, although welfarist measures have historically and today claimed to act as a platform for uplift, in truth, uplift often constitutes little 
more than systematically treating users as surplus labor or surplus life, which means users benefit the least from these systems (Willse 2015).

For some, like Daisuke and Asri, having housing and/or employment is far more desirable than not having them—and access can therefore be life-changing. However, as their experiences reveal, access alone does not necessarily guarantee any advantageparticularly where protections either do not exist, or systematically fail. On a macroscale, privatization, devolution, and state practices of inaction (e.g. failing to prevent pinhane through regulation) and passive action (e.g. selectively blacklisting actors suspected of pinhane after it occurs) that, together, characterize neoliberal-era welfarist policy offer little assurance to persons experiencing homelessness. While many people may gain short-, medium-, and even long-term security through such measures-as Daisuke, Keisuke, Sim, and Zali each have to varying degrees—success relies too much on people "mak[ing] it work" and not enough on processes that ensure that policy will work, in their interest and for their sake. The security that Keisuke has gained at Tsukuroi stands as evidence of the importance of weeding out pinhane if we are to provide more effective support to people seeking housing, employment, and other forms of assistance. Policy users should not have to gamble on whether or not any given service provider or employer is sufficiently responsible, respectful, or kind. Ensuring exits from homelessness, as well as greater livelihood and housing security, requires enough political will to ensure that institutions "make it happen".

Just as importantly, political will cannot—and must not—-be framed as essential to providing assistance for people experiencing homelessness, but rather as essential to providing assistance more democratically according to and with people. Widely held 
skepticism regarding programs, as articulated by Rafi and Toya, for instance, and problems like "disappearances” stemming from negative experiences with programs are products of the failure to adequately consider the experiences and interests of policy users. For this reason, it is imperative that public agencies recognize these problems as indicative of trouble in policy (rather than policy users) and remedy them by ensuring people like Sim, Toya, Tetchan, and Mohammad have greater influence and control over the formation of policy and the determination of policy outcomes. Otherwise, people experiencing homelessness are left with little recourse but to ensure their own security, such as by conducting their lives in public spaces wherever alternatives are not available or not tolerable. Similarly, to the extent that broader society fails to ensure livelihood security, many people will feel they have little recourse but to enter low-paying or illicit vocations, such as collecting recycling, panhandling, or engaging in black market vending or sex work. These choices occur not because people reject social values and norms, but because social values and norms deny particular people adequate humanity.

\section{Conclusion}

Social policy emerged in the early twentieth century to provide "uplift" to the working classes at a time where governments sought to locate "skilled and unskilled labor where it was most needed” (Wallis 1902:773).While many programs did indeed improve quality of life, they nonetheless prioritized aims that reflected the political and economic interests of the middle- and upper-classes as, in a limited democracy, only the latter had platforms for shaping policy. Consequently, institutions of welfare, labor, and

care-developed in the interest of extending capitalist productivity, that is, bolstering and 
extending life in accordance with raced, classed, gendered, and abled systems of valuation—offered only limited socio-spatial mobility, much as democracy itself was limited.

Although policy systems were recalibrated over the post-WWII era, this process, largely overseen by American and British agencies, generally replicated prewar institutions, practices, and norms (Garon 1998; Harper 2001; also, Chapters 2 and 3), though it was organized into new systems that rhetorically foregrounded welfare ideals of egalitarianism in Japan and developmentalism and philanthropy in Malay(si)a.

Consequently, although postwar policies were upheld by international institutions as infrastructure for leveling the playing field on both global and local scales, results have been uneven. While some policy users indubitably benefit from policy, positive outcomes should not overshadow the injustice inherent to programs that systematically consign people to conditions of social and economic insecurity and even fail to protect them from exploitation and harm.

This is not to say that welfarist institutions of care are inherently exploitative or abusive. However, they have accommodated practices of pinhane, or labor exploitation, in both Tokyo and Kuala Lumpur across the twentieth and twenty-first centuries and this relationality between pinhane and public institutions is not often enough directly addressed. Scholarship has explored the limits of social and spatial mobility imposed by homelessness and homelessness policy through conceptualization of the medicalization (Lyon-Callo 2004) and value of homelessness (Willse 2015). More research is needed to better identify how and why the socio-spatial mobility, or liberty, of resourced actors has 
been historically and today founded on the political, social, and geographic immobilization of others through policy. 


\section{CONCLUSION}

Lessons from History

Neoliberal transformations

Neoliberal shifts have altered distributions of wealth and perceived need for state programs in both Japan and Malaysia. Moreover, from among these changes, two in particular have shaped homelessness regulation in each country's capital. One is the transnationalization of labor markets and production processes over the last half-century as this underpinned deindustrialization, economic restructuring, and labor deregulation in Japan (Hasegawa 2005; Simeon and Ikeda 2003) and the concentration of transnational service $^{100}$ and manufacturing industries and migration corridors in Kuala Lumpur and Southeast Asia (Kaur 2010). The other key factor is the international financialization of municipal debt and redevelopment, which has spurred accelerated growth in urban infrastructure-including through transfer of public assets to the private sector (GlobalCapital 2007; Jessop 2015; Kirkpatrick 2017; Rutland 2010). Together, these shifts have altered avenues by which individuals and households may achieve socioeconomic security directly through employment and social services and indirectly through public- and private-sector investment in urban infrastructure.

These shifts have also shaped the tone and form of civic action and political movements in both cities. In Tokyo, for instance, increased collective insecurity in housing and employment has led to new kinds of poverty, identified through neologisms

\footnotetext{
${ }^{100}$ In particular, transnational services such as call centers.
} 
like freeters, net café refugees, and the precariat (Allison 2014; Amamiya 2007; Obinger 2009; Ronald and Hirayama 2009). In Japan, where publics had identified overwhelmingly as middle-class through the late twentieth century, these changes have fueled public demand for the reinforcement and strengthening of socio-legal protections: while left-leaning publics call for the fortification of welfare-state programs and civic rights right-leaning publics turn to so-called traditional systems of patriarchal (and ethnonationalist) protection. Moreover, although many civic actors from various political camps openly critique neoliberal shifts, they also tend to view past welfare-state and/or other patriarchal systems with nostalgic rose-colored lenses. This nostalgia reduces attention to the intrinsically exclusionary—rather than inclusionary—nature of these historic models, thus enabling their propagation.

Conversely, in Kuala Lumpur, predominantly middle-class civic movements seeking to reduce the social and economic tensions of a highly unequal society has claimed active interest in philanthropic interventions—ranging from welfarist measures like financial relief to neoliberal remedies prescribing employment-based "self-reliance" and the prohibition of life-sustaining activities. While civic movements have gained democratic strength, they also overwhelmingly choose apolitical approaches to aid that sidestep critique of prevailing political-economic systems of distribution ${ }^{101}$, which are now weighed in the favor of the middle class. Consequently, civic groups tend to support or endorse solutions that align with—and even strengthen—dominant global capitalist systems, including those that assign responsibility for public well-being to individuals,

\footnotetext{
${ }^{101}$ Except for when it comes to corruption, assumed to be the primary barrier to a more functional and fair capitalist democracy.
} 
households, and (ethnic) communities as opposed to public- or private-sector institutions. These dynamics exacerbate problems for working-class communities and households not only because labor and welfare protections remain weak—thus, prolonging livelihood insecurity—but also because accelerating urban development necessarily suspends and invalidates informal markets, resulting in greater dispossession and impoverishmentamidst fewer avenues to security.

These transformations underscore the past and present role of formal labor and housing markets—and, in advanced capitalist countries, welfare-state systems—in ensuring generally uniform standards of living for normative households. Conversely, the piecemeal nature of markets and social policies has long complicated livelihood security for people in post/colonial countries, which have uncoincidentally served as global capitalism's reserve pools of labor and land. In Malaysia, community, family, and informal markets have been critical buffers for reproduction, and survival, in lieu of the welfare state. Concurrently, the role of police and other agencies concerned with social and spatial security have been, across both contexts, deployed to bring order to areas beset by insecurity. In post/imperial Tokyo, the welfare state has insulated large swathes of the population from homelessness and other forms of socio-economic insecurity, thus making it seem like a much more exceptional problem—more easily attributable to individual fault. Hence, security measures like Sanya Taisaku were adopted only on a smaller scale. In both countries, the scope of security measures has little to do with the people thrust into insecurity, and everything to do with the globally circulating capitalist ethos surrounding social and spatial disorder itself. 
Hence, political-economic shifts have also stirred a resurgence in historically entrenched ideas that cast poverty as contrary to modernity. In Kuala Lumpur (Chapter 2), economic growth and the ever-increasing visibility of affluence has reinforced an Other-ing of urban poverty and stoked interest in erasing evidence of such so-called "backwardness" from view. In Tokyo (Chapter 3), the neoliberal abandonment of welfare-state ideals—once viewed as evidence of a "civilized" society—amidst the Global North's race to the bottom has triggered longstanding anxieties surrounding (racialized) "idle” persons prone to "deviance" and "dependency”. Consequently, in each country, civic compassion is necessarily tempered by defensive concerns that "uncivilized”—or anti-social—marauders seek to prey on generosity (also see Kaika 2017). The neoliberal state has largely benefited from these rising insecurities and tensions by offering civil society the mantle of "civilized" welfarist action, while public agencies dedicate themselves to the marketization of public space and the rational management of public order, designed to minimize the physical presence of people on the streets (Chapter 4) and relocate and rehabilitate people through housing-first and workfirst programming (Chapter 5). Against this background, many middle-class organizations have welcomed the devolution, or responsibilization, of welfare as they are granted greater "leadership” over clients, as well as greater material resources and political influence.

Imperial legacy

Understanding continuities and changes across time requires knowing the origins and structure of welfarist aid. The advance of social policy in the early twentieth century, 
particularly within democratizing imperialist states like Japan, offered enhanced protections but only to the extent permitted under locally and globally raced, gendered, classed, and abled divisions of labor, modified across time but fundamentally sustained. Consequently, the distribution of welfare aid for people deemed unproductive (and, conversely, labor protections for those deemed productive) did not then, nor does it now, protect all people equally. Hence, while particular forms and degrees of inequality may shift over time, the uneven nature of the landscape remains fundamentally unchanged. For instance, historically and today, people who are born into marginalized positionsand especially those who defy gendered, abled, raced, and/or classed conventions ${ }^{102}$ reinforced via socio-legal norms—experience reduced access to education, employment, housing, and social support by virtue of their social position. This uneven terrain not only underlies specific vulnerabilities to becoming homeless but also guides exclusionary tendencies in homelessness regulation as policy targets are scrutinized in programs designed to rehabilitate them in line with the same unevenly determined conventions and norms.

Consequently, historically and today, the process of providing people experiencing homelessness with assistance typically involves granting facilities the authority—via implicit or explicit approval by state institutions—-to unilaterally impose on residents certain standards of living (such as those determining privacy and diet) and/or regulations of conduct. Historical examples include early twentieth century workcamps or mid-twentieth century arranged marriages for homeless women and girls,

\footnotetext{
${ }^{102}$ Which, for most, dictate being a dependent in and/or becoming dependent on someone else's household.
} 
and postwar institutionalization of persons with disabilities and mental health needs. Today, uneven standards and practices-illustrative of a systematically-reinforced gap in material security between people who are raced, classed, gendered, and abled in varying ways persist in both Japan and Malaysia. For instance, just as men who did not fulfill breadwinning norms were historically segregated within employment-centric disciplinary institutions (including Japan's yoseba), similarly labor-capable men today are expected to make use of Self-Reliance Support Centers and transitional shelters like Pusat Transit. Other people such as single mothers, people with disabilities, and foreign citizens, are also managed using particular disciplinary institutions (Foucault 1977, 1998) that offer users limited choices, thereby compelling conformity or bearing the risk of unprotected existence like homelessness.

Institutions of labor and care are, thus, shaped by patriarchal relations of power that guide the social and economic prospects—and future course — of most individuals in society. These relations of power between ostensibly normative and non-normative actors explain how policy users are systematically subjected to not only institutionalization (forced detention), "medicalization,” and "pathologization” (Lyon-Callo 2004; Mills 2015; Willse 2015) but also pinhane, or exploitation too. However, it is also worth considering why public- and private-sector actors have for so long actively or passively condoned these and other practices violating the rights and dignities of policy users. As discussed in Chapter 4, these practices are not only undemocratic, but anti-democratic, as they manifest indifference to the will and the well-being of policy targets and users. So why would they prevail for over a century of modern policy, including over a halfcentury of ostensibly democratic rule? 
These institutions appear paradoxical because of how they deliberately limit, and even undermine, the material security and socio-political rights of policy users, all while asserting that such limitations are in users' best interests. But this structure lies at the root of the imperial formation borne from Lockean ideas of liberal citizenship determined through litmus tests that bar inclusion to people viewed as insufficiently civilized or capable of reason. This template for social order fundamentally functions to affirm the social and political claims to power of people—-predominantly in the middle and upper classes—who view themselves (despite their own individual nonconformities ${ }^{103}$ ) as a normative modern public. That is, in both post-imperial countries like Japan and postcolonial countries like Malaysia, people presumed to embody social values and norms — often merely by virtue of their race, class, gender, and ability—-have much to gain from homelessness regulation in terms of political and economic protections and benefits, including those shaping democratic systems.

\section{Global capitalism, Compassion, and Paternalism}

In Tokyo and Kuala Lumpur alike, avenues provided under policy for ameliorating homelessness generally prioritize the provision of employment and/or accommodation. Historically, these were offered in each country through public sector institutions like welfare homes (kōsei shisetsu) and yoseba in Japan, and Desa Bina Diri in Malaysia. The scope and range of supportive aid in Tokyo prior to the 1990s was far

\footnotetext{
${ }^{103}$ In law and practice, benefits accrue to people according to their fulfillment of norms, including class, or material norms. The trick underlying meritocracy is that possession of material wealth, by definition, stands as evidence of one's merit, thus offering a "pass" to people of middle- and upper-class status to violate norms.
} 
more extensive than that in Kuala Lumpur, owing to the welfare state's financial and institutional resources, on one hand, and political will invested in achieving full employment, on the other. Both stemmed in large part from the global importance of welfare and full employment as markers of advanced status and national stability. However, while welfare-state infrastructure has been gradually dismantled in advanced post/imperial states globally, access to welfare has grown in Malaysia, particularly since the 1990s. That said, welfare aid remains as a rule piecemeal and meagre; however, its expansion in the regulation of homelessness does spotlight avenues to labor, as seen in government-established Anjung Singgah shelters.

In Kuala Lumpur, policy approaches to resolving homelessness have shifted considerably over the last decade. Where mass roundups, compulsory detention, and rehabilitation programming once constituted the core of policy solutions ${ }^{104}$, direct and voluntary avenues to temporary accommodation and private-sector employment are now treated as most favorable. This work-first approach has been instituted into policy through the proliferation of government-established Anjung Singgah shelters and the newer men’s facility, Pusat Transit. In addition, officers at Anjung Singgah are also responsible for accepting and referring users to existing public- or civic-sector services, where possible, such as those for women escaping domestic violence, pregnant women, senior citizens, and persons with disabilities. These changes stem from recent decades of economic growth, which have led to extensive demand for low-wage labor in service industries like hospitality and security, on one hand, as well as the rise of a Malaysian

\footnotetext{
${ }^{104}$ It is important to remember that across their history, these measures have also been continually touted as compassionate.
} 
middle class interested in further advancing in socio-economic status via entrepreneurship relying on low-wage labor or philanthropic expressions of compassion.

This model of differentiated service coordination in Kuala Lumpur's shelters effectively functions to "sort” through people experiencing homelessness, much like rescue operations still do. However, while shelters generally link individuals to aid that splits them between productive and reproductive realms, rescue operations are designed to reduce the public presence of particular populations-such as non-citizens, drug users, and persons with disabilities as detained by Immigration, the Anti-Drug Agency, and Social Welfare Department, respectively. Stated differently, local homelessness regulation in particular, and welfare policy systems in general, have come to resemble those once considered archetypical in industrialized welfare-state systems, except for their distinct: a) lack of rights to and guarantees for protection, and b) more devolved and privatized form. Labor-capable persons_-predominantly men-are channeled to privatesector employers, while non-labor-capable others are directed to public- and civic-sector spaces of care.

Sustained national growth may underlie increasing public, private, and civic sector generosity but poor enforcement of labor regulations, where regulations exist at all, and a lack of secure, regularized access to public aid means that most people experiencing homelessness have few options besides seeking refuge in spaces like Hang Lekiu Street, where Kuala Lumpur's non-profit industrial complex (Willse 2015) is arguably taking shape. Consequently, as compassionate actors from all sectors converge on Hang Lekiu Street to provide direct aid, so do opportunistic agents of pinhane exploitation. That is, both compassionate and exploitative agents are necessarily drawn to 
these spaces because of their social and economic disparities. Moreover, while compassionate acts are not necessarily deliberate acts of exploitation, they nonetheless benefit actors in myriad ways.

At the same time, as shelter infrastructure has been maintained and slightly expanded through the late twentieth and early twenty-first century in advanced capitalist countries, policy innovations have tended to gravitate towards housing. In Japan, homelessness policy increasingly centers housing security above that for employment. This partial shift, akin to Kuala Lumpur's partial shift from "rescue" to shelters, is generally credited to the advance of more caring and constructive approaches by voluntary and civic agents. However, the diffusion and continuation of these policies also rests on the political and economic interests of resourced actors—and especially those in the public sector tasked with the redistribution of public accountability, public cost, and public assets amidst rising urbanization and austerity (Peck 2015).

Hence, in Tokyo, for example, wherever public sector programs direct people in need to housing or employment, not only do pinhane agents emerge to profit from policy, but the political will necessary to stop them fails to surface. This inaction directly results in harm to policy users. Moreover, it inspires and sustains their reluctance to consider public aid. An identical pattern is visible in Kuala Lumpur where companies and labor brokers seek potential workers for low-wage and/or outright exploitative work at government-established shelters, CSO activities, and parks and other public spaces. Government refusal to address problems such as these underpins reduced interest in public shelters, one way in which people may protect themselves from the negative 
ramifications of policies that fail to honor their interests ${ }^{105}$. However, the uneven, topdown nature of governance means that responses tend to paternalistically treat this resistance to programs as evidence of the "uncivilized" or unruly character of policy targets, thereby justifying measures aimed at bolstering public order and coercing welfare uptake rather than improving programs in line with input from prospective and current users.

Institutions of care and control

Since the twentieth century, both welfare and public order measures have had profound effect on the mobility of people experiencing homelessness, especially in light of their socio-economic circumstance. Public order measures, for one, render people experiencing homelessness a target and thereby limit their ability to move through public space, such as where quality-of-life rules or other regulations require reproductive (survival) activities be conducted in private space (Skolnik 2018; Waldron 1991). Second, social policy effectually controls mobility by regulating both opportunity for movement and its terms. This can be seen in how it facilitated Keisuke's move from Shinjuku Central Park to multiple facilities around Tokyo, each accessible only through gatekeeping agents at the welfare office and accommodation facilities alike. Similarly, Lim moved between Kuala Lumpur and Desa Bina Diri in Jerantut, initially under the authority of law and later in contravention of it. That is, by obligating or offering accommodation, social programs and policies facilitate relocation but always contingent

${ }^{105}$ Also see Skolnik (2018). 
on conditions that tend to deliberately guide movement to or from particular centrally and remotely located regions.

Controls on mobility constitute another legacy of empire, formed in the image of global imperialist networks for procuring human resources. That is, the movements of policy users facilitated through welfare and public order interventions illustrate how the socio-legal delegitimization of homelessness has served - historically and today-to mobilize people (human resources) across globally-formed public- and private-sector networks. Functionally, public- and private-sector agents of these networks offer social and economic support only on the condition that people agree to geographic relocation. Moreover, despite claims that it stands as an opportunity for social and economic advance, geographic mobility has long been fraught with risk-even where facilitated through public sector institutions. Seen in this light, the dubious past and present outcomes of social policies governing homelessness are indeed systemic.

Social policy and public order regulation also control social, in addition to geographic, mobility. This is achieved through legal limits on material and economic benefits, as well as through pinhane exploitation. For instance, historically and today, supportive facilities have deliberately incorporated penalties like discomfort to discourage extended use. Similarly, economic aid has long been limited, ostensibly to prevent dependency. These controls constrain social mobility to varying degrees, but are regularly justified as essential for incentivizing independence and self-reliance. Control of both social and geographic mobility enforced in public space (Chapter 4; also Column A of Table 6) and related welfare institutions (Chapter 5; also Column B of Table 6) have 
been replicated over generations because of how they necessarily benefit resourced groups, from public and private sector actors to the public at large.

\begin{tabular}{|c|c|c|c|c|}
\hline \multicolumn{2}{|c|}{\begin{tabular}{|l|} 
Policy-based \\
Governance of \\
$\ldots$ \\
\end{tabular}} & A. Street Homelessness & $\begin{array}{l}\text { B. Shelters and other } \\
\text { Rehabilitative or Custodial Spaces }\end{array}$ & C. Channels of Labor \\
\hline \multirow[t]{2}{*}{ Malaysia } & Public & $\begin{array}{l}\text { Multi-agency } \\
\text { operations (Anti- } \\
\text { begging; Anti- } \\
\text { vagrancy) } \\
\text { BR1M (One-off welfare; } \\
\text { national) } \\
\text { Baitulmal (One-off } \\
\text { welfare; Muslim } \\
\text { only) }\end{array}$ & $\begin{array}{l}\text { Anjung Singgah (Welfare \& Labor) } \\
\text { Pusat Transit (Men only; Labor) } \\
\text { Desa Bina Diri (Persons with } \\
\quad \text { disabilities, mental health } \\
\text { conditions, etc.) } \\
\text { Rumah Seri Kanangan (Seniors) }\end{array}$ & $\begin{array}{l}\text { Employer-provided } \\
\text { Accommodation } \\
\text { (e.g. Restaurants, } \\
\text { Construction, } \\
\text { Security, } \\
\text { Manufacturing, } \\
\text { etc.) }\end{array}$ \\
\hline & Civic & $\begin{array}{l}\text { CSO meal services, } \\
\text { clothing distribution, } \\
\text { medical care, } \\
\text { counts/surveys, etc. }\end{array}$ & $\begin{array}{l}\text { CSO shelters addressing homelessness } \\
\text { among specific demographic } \\
\text { groups, i.e. women, children, } \\
\text { persons living with AIDS }\end{array}$ & $\begin{array}{l}\text { Skills training } \\
\quad \text { programs } \\
\text { Internships } \\
\text { Etc. }\end{array}$ \\
\hline \multirow[t]{2}{*}{ Japan } & Public & $\begin{array}{l}\text { Multi-agency outreach } \\
\text { (initiated under } \\
\text { Transition-to- } \\
\text { Community-Life } \\
\text { Program) } \\
\text { Extra-legal assistance } \\
\text { (One-off welfare) }\end{array}$ & $\begin{array}{l}\text { Livelihood Assistance } \\
\quad \text { (Apartment/Doya/SRO/etc) } \\
\text { Self-Reliance Center + Transitional } \\
\quad \text { Housing (Labor) } \\
\text { Housing-First Pilots (Not reviewed) }\end{array}$ & $\begin{array}{l}\text { Employer-provided } \\
\text { accommodation, } \\
\text { i.e. Asrama/Hanba } \\
\text { (Construction, } \\
\text { Manufacturing) }\end{array}$ \\
\hline & Civic & $\begin{array}{l}\text { CSO meal services, } \\
\text { clothing distribution, } \\
\text { medical care, } \\
\text { counts/surveys, etc }\end{array}$ & $\begin{array}{l}\text { CSO shelter and } \\
\text { Housing-first programs } \\
\quad \text { addressing homelessness among } \\
\text { non-specific and specific } \\
\text { demographic groups }\end{array}$ & Big Issue - Japan \\
\hline
\end{tabular}

Table 6. Institutions involved in public order and social welfare measures.

The addition of multiple agencies — and multi-agency teams — to outreach and rescue operations in Tokyo and Kuala Lumpur, respectively, has served to maximize the efficacy of interventionary objectives_-and especially those related to public order 
enforcement: the reduction of inappropriate use of public space, or visible street homelessness. These interventions undermine the ability of people experiencing homelessness to claim their basic rights to public space—and the free exercise of rights in such space (Waldron 1992). This is made clear in instances where Kei was regularly photographed and disciplined by public officers in Yoyogi Park, Yanagi was physically removed from a residential park near Sanya, and Azleena and Sim were taken into custody during rescue operations in Kuala Lumpur. Exclusionary public order measures are designed to incentivize and compel the uptake of social programs, or self-reliance more generally, while also protecting public property from perceived disorder or harm. Such measures benefit the non-homeless public in subtle ways by, for example, leveraging the latter's claims to public property. In Tokyo, this advantage is founded on the supposedly "appropriate” or law-abiding nature of their public space use, whereas in Kuala Lumpur it is founded on the distinction of not being a "destitute person".

Capitalist divisions of labor and global homelessness

Moreover, social and geographic mobility in each city has also been controlled according to globally and locally determined divisions of labor. That is, a review of each city's policy landscape reveals that the direction, or outcome, of street-level interventions generally hinge on a target's gender, class, race, and ability because these factors are taken to be indicators under capitalism of individual propensity for reproductive and productive labor and, by extension, the trajectory of modern life. More specifically, as shown in transhistorical analyses of policy in Kuala Lumpur (Chapter 2) and Tokyo (Chapter 3), consideration of physical and mental health, citizenship, (perceived) gender, 
linguistic ability, age, ethnic background, and state of dress, among other things, are considered key factors for determining assistance, whether through institutions of care or control such as employment referral services, hospitals, immigration officers, or police. While individuals have some degree of agency and choice, disproportionate power is granted to gatekeeping public- and private-sector policy agents including bureaucrats determining policy and implementation.

Historically, within institutions of care such as hospitals and shelters, aid has been allocated paternalistically in line with what policy agents deem to be necessary or deserved. For instance, in Kuala Lumpur and Tokyo in the 1930s, girls and women experiencing homelessness were provided shelter where they were trained as wives for marriage. Today too protection offered to women and girls both reflects and reinforces their ties to the reproductive realm as aid and accommodation concentrate on protecting them from domestic abuse, supporting single mothers, and generally keeping them off the streets and apart from men. Similarly, welfare programs offering immediate aid for children, persons with disabilities, senior citizens, and other protected groups have also existed in both cities. However, access to aid or shelter in and of itself guarantees neither the quality nor sufficiency of assistance. Moreover, target groups are generally granted only limited right to refuse such care—as illustrated by Zali and Sim's experience with Desa Bina Diri and Kei's explanation of how elderly and ill persons in Yoyogi Park are targeted for discipline, or advice, by patrols.

Historical analysis shows that in each city across time, particularly from the early twentieth century, policies addressing the homelessness of labor-capable men offered substantial material support and enabled greater mobility—but limited economic aid to 
prevent so-called dependency; together, these measures were designed to bolster men's self-governance. As recognized by Isomura Eiichi in 1959 (Iwata 1992:21), this also ultimately resulted in their positioning "outside the scope of modern welfare". Moreover, the disproportionate social and political influence of heterosexual men in patriarchal society, cutting across social institutions, resulted in a privileging of their voices and interests and, consequently, the power of their claims — as long as these aligned with dominant notions of respectability. Concurrently, organizations centered or sidelined the voice and interests of people according to perceived status via considerations beyond gender alone, such as race, ethnicity, age, citizenship, and ability. Hence, public and civic institutions alike, when working with homelessness policy, have historically tended to invest more political urgency and economic resources in resolving homelessness as it relates to, for instance, cis heterosexual male unemployment—albeit tempered by a modicum of investment in persons with disabilities, women, senior citizens, and other groups wherever they are perceived as deserving of aid. Today, these tendencies are expressed in the quick provision of shelters and other facilities for employable persons, and especially men, as seen in Tokyo's Self-Reliance Center and Kuala Lumpur's Anjung Singgah and Pusat Transit.

Gendered norms—and masculinist demands for breadwinning and "self-reliance" in postwar Japan were instrumental in producing a masculine stigma against accepting welfare, viewed as dependency on the state, and a feminine stigma against refusing paternalist care from partners, birth family, or the state. In postcolonial countries like Malaysia, on the other hand, the state insisted that all members of the public had to take care of themselves; hence, self-reliance is more generally applied to all of society. Seen 
in this light, it becomes clear that neoliberalism reintroduces norms once imposed by imperial countries on their former colonies (Halperin 2015). As industries grew more globally mobile in the 1970s and 1980s, and the emergent neoliberal economy took shape, it gained its footing by reducing expenses incurred in the procurement of human and natural resources, much like the industrial economy that preceded it. This manifested in the feminization and transnationalization of labor from the 1970s, the automation of labor from the 1980s, and widespread labor deregulation from the 1990s.

Socio-spatial Governance: The Relation between Public Order and Welfare

The social and spatial management of street homelessness in Tokyo and Kuala Lumpur falls under more than just penal and welfare arrangements. Non-welfare agencies managing transportation, sanitation, parks, and immigration enforcement at national and municipal levels of government also have clear and concrete protocol for engaging with persons experiencing homelessness, as seen in policy, protocol, and practice in both cities under Japan’s MLIT, Malaysia’s Immigration Bureau, the Tokyo Metropolitan Government, and KL City Hall, among others. This co-integrated multi-agency approach has advanced rapidly over the last thirty years, gaining ground with each new wave of law and policy. In the case of Tokyo, it was formally instituted in national law ${ }^{106}$ in 2002 with the enshrinement of powers to "enforce appropriate use" of public facilities in Article 11 of the Self-Reliance Support Act. These powers were then systematically operationalized in 2004 through the establishment of new institutions and protocols for

\footnotetext{
${ }^{106}$ Albeit preceded in practice by railway and other transportation and urban infrastructure authorities.
} 
enforcement in Tokyo’s Transition-to-Community-Life Program. In Malaysia, changes took shape sooner as, initially, immigration and anti-drug agencies were incorporated into frontline operations in the 1980s and 1990s. Then, over the last decade, City Hall and the Federal Territories City Planning Department (both non-welfare agencies) have taken increasingly active and dominant roles in the management of Kuala Lumpur's homelessness programming — both in terms of street (rescue) operations and transitional (welfare) shelters.

Neoliberalization of the Janus face

This broader landscape of Janus-faced compassionate and corrective ambitions in law and practice carries two distinguishing characteristics animatedly differently through Japan's welfare-state and Malaysia's non-welfare-state infrastructure. The first characteristic is that contemporary policies necessarily fuse public order and welfare measures. As detailed in each of Kuala Lumpur's and Tokyo's policy histories, this fusion of caring and controlling structures and functions traces back to the incorporation of welfarist measures into public order governance at the turn of the twentieth century. Today, the neoliberal expression of these policy aims is realized in Japan's dual focus on individual socio-economic self-reliance and "appropriate use" of public assets, while Malaysia’s dual concern centers on imperatives of care and control—for the sake of rescue and image. In each country, policy narratives surrounding these dual focuses tend to imply that failure in one regard, namely, social or spatial development, necessarily threatens the other. 
The second characteristic of Janus-faced regulation is the pairing of overbroad and vague public order statutes with welfare provisions that narrowly define targets and are commonly operationalized in an extra-legal sphere. In practice, this is seen in Kuala Lumpur in application of the Destitute Persons Act as a means to clear the streets, and how this is offset by the practice of providing shelter or welfare assistance to only limited categories of persons, where contemporary modes of the former is administered by civic, private, or quasi-government organizations. In Tokyo, it is found in the practice of overbroad prohibitions against "inappropriate use" balanced by welfare assistance limited to either extra-legal support (hōgai enjō) channels outside of Livelihood Protection, or channels within Livelihood Protection where extra-legal consideration of an applicant's unsheltered status results in their referral to specific institutions, facilities, or treatment. This distinct trend in law and practice has emerged from increased public sector prioritization of urban redevelopment, investment markets, and the devolution of social protections.

On one hand, the public order measures in this pairing enable government to incorporate increasing numbers of agencies ${ }^{107}$ into measures like Tokyo's park patrols or Kuala Lumpur's rescue operations, while also adjusting target groups or actions over time. For instance, although enforcement in Tokyo initially focused on five park encampments, it has since expanded to include new geographic regions, management agencies, and "inappropriate" uses of public space such as sleeping on benches, resting on sidewalks, and leaving bags unattended. Similarly, in Kuala Lumpur, new multi-agency

\footnotetext{
${ }^{107}$ As law itself does not specifies authorities with purview.
} 
teams now tackle begging, rather than vagrancy, in an expansion of prior multi-agentic applications of the Destitute Persons Act. On the other hand, welfare measures targeting people experiencing homelessness limit the scope of persons eligible for aid, and the number of public agencies responsible for such aid. For instance, assistance through the Transition-to-Community-Life Program (2004-2009) was offered only to tent residents in five select parks, and only under particular terms and conditions. Similarly, Taito Ward’s Housing First pilot program (2019) grants aid only to persons identified as chronically homeless. In Malaysia, shelter programs revolve around linking people to employment or, to a lesser degree, already-limited public and civic resources. As a result of overbroad public order directives and narrowed welfarist protections, new policies propagate social and spatial insecurities by facilitating clearance and limiting access to aid. Moreover, implementation in each case may well bypass civic rights.

This Janus-faced structure is itself a legacy of imperial governance. It renders unsheltered existence illegitimate through the enforcement of broad public order regulation and restricted welfare measures. That is, while public order measures may more perceptibly delegitimize street homelessness, welfarist measures achieving the same ends more subtly by foreclosing access to aid and other modes of protection to people in states of homelessness. That is, while distributions of emergency aid such as meals or clothing may reach people lacking housing, long-term forms of supportive assistance require applicants enter state-mandated or approved rehabilitative accommodation. Stated differently, substantive aid is rarely granted to people in states of homelessness because welfare has historically served to incentivize compliance with social divisions of labor and, where one does not work, subordination to paternalistic care, all organized spatially. 
As Chapter 4 shows, people approached by policy agents today are systematically pointed towards available public resources or aid, such as Tokyo's self-reliance and housing-first programs or Kuala Lumpur's rehabilitation centers and shelters. Yet, as illustrated in Chapter 5, aid is typically conditional on entry to institutions that have authority to unilaterally determine what is best for policy users. As reported by Jaya in Kuala Lumpur and Officer Tanaka in Tokyo, policy agents are responsible for prescribing how to "be normal". Moreover, in many instances, people who refuse avenues to aid—such as Kei, Jaya, and Toya—will experience reproach. Ultimately, both public order and welfare aims are designed to meet the prerogatives of state agentsoften focused on urban redevelopment and the financialization of markets—rather than the unconditional strengthening of human security. This bias is reflected in policy objectives that, for example, prioritize the reduction of tents above all else in Tokyo or the integration of CSO actors into Kuala Lumpur's "proper [government] channels” for aid.

Animation across welfare-state and non-welfare-state infrastructure

Neoliberal era shifts in homelessness regulation necessarily differ across Tokyo and Kuala Lumpur in line with each capital's developmental context and, more specifically, its historically entrenched public order and welfare systems. In Japan, where the welfare state is presumed to serve as a floor for managing social protections and public needs, including those pertaining to homelessness, the question of public order has also fallen to separate, specialized agencies such as those charged with responsibility for ensuring “appropriate use” today. As a result, even though management of homelessness 
itself is both social and spatial (as epitomized in patrols by welfare agents and social outreach by non-welfare agents), agencies must nevertheless ultimately align their objectives with either public order or welfare goals. However, in Malaysia, the lack of a welfare state has meant that welfare and public order ambitions relating to homelessness have long been fused within a single policy ${ }^{108}$ —and, for the most part, the only policy to address homelessness. Hence, narratives produced by agencies in Kuala Lumpur are simultaneously concerned with security- and welfare-oriented aims of clearance and rescue as a means to justify actions (like the SEA Games two-month "boot camp") that resolve both in one fell swoop. New shelters too are expected to help clear the streets, as evidenced by government insistence that not only people experiencing homelessness but also CSOs offer services in government facilities rather than on the streets.

Interestingly, government data collection methods in both cities suggest that between welfare and public order measures, the latter rank as a higher priority among public agencies ${ }^{109}$. For instance, data tabulated and publicly released regarding entrants in Tokyo's Transition-to-Community-Life Program seems to end in 2009, the Program's final year of registration, making it difficult to determine the effectiveness and long-term outcomes of assistance. However, annual counts of tents throughout Tokyo, first collected in 2004, are easily found, regularly updated, and actively utilized by multiple agencies today, as are yearly street counts and surveys. In Kuala Lumpur, the state has

\footnotetext{
${ }^{108}$ Today this policy is the Destitute Persons Act, an adaptation from the Vagrants Act (1965) and its predecessor colonial-era vagrancy law.

${ }^{109}$ Meta-governance of social services (Willse, 2010) may be taking shape in Japan, and public order controls would certainly support its aims. However, the effect of recent regulation on case management and facilities themselves is beyond the scope of my research.
} 
yet to develop a system for following up on former shelter clients at Anjung Singgah (est 2011) or Pusat Transit (est 2015) to measure the short-, medium-, or long-term impacts of employment referrals, but GIS maps of "hotspots" and other geographic and demographic data on street homelessness is produced and updated regularly using PIT counts. Hence, qualitative or quantitative data illustrating whether and how supportive programs may succeed in either Tokyo or Kuala Lumpur is sparse, contrasting ample quantitative charts of street homeless populations.

Moreover, because public-, civic-, and private-sector organizations carry disproportionate power in controlling narratives about services, failure tends to be attributed to the shortcomings of policy users. That is, imbalances in power mean that the effects of policy are woefully misunderstood. Policy narratives reveal these imbalances as they advance misunderstandings often rooted in the whims and fancies of compassionate actors. For instance, the idea advanced in Kuala Lumpur that someone can be "rescued" from the streets is, as Sim and Zali's experiences suggest, a profound misrepresentation of how homelessness is experienced and what could be done to reduce it, not to mention a misrepresentation of policy action itself, as Azleena would point out. Similarly, the idea of self-reliance as a solution, popularized in policy in Tokyo, is equally problematic considering that surviving street homelessness, on the one hand, requires remarkable capacity for self-reliance and, on the other, that the roots of policy failure lies less in moral or disciplinary failing and more in how users are compelled to sacrifice individual liberty, socio-economic security, and/or psychological well-being to "make [programs] work", as Keisuke found. 
Similarly, the recent proliferation of concepts like "chronic homelessness" and "service resistance” in Japanese and Malaysian literature and programming are more telling of a relatively global ubiquity of problems inherent to policy responses and ways of thinking about homelessness, than qualities inherent to people grappling with homelessness itself. These trends—often borrowing from conceptual frames that relate homelessness to addiction, disease, and non-conformity—speak volumes about scientific ignorance of problems ingrained in institutions delivering services, which profoundly and repeatedly shapes policy knowledge transnationally. Attention I have given to users' experiences underscores how institutional problems are often at the root of resistance to services (see also Willse 2010), rather than any inherent failing of people experiencing homelessness. The blind eye directed at the institutional roots of policy failure reflect and reinforce compassion that, as (Arendt 1965:79) warned, may be "enjoyed for [its] own sake, and almost automatically lead to a glorification of its cause, which is the suffering of others". That is, compassion rooted in uneven power relations and imperial legacies inspires governance that cannot but see people as needing rescuing, guidance, and reform.

This is because compassion plays out in policy in ways that necessarily defer to the wishes of the more resourced actors: policy agents. In Japan, the introduction of the Self-Reliance Support Act as well as the subsequent shift to subsidized housing and housing-first programs each prioritizes the agenda of public actors in their focus on particular solutions, such as employment or the use of aging and devalued housing stocks. Similarly, in an era where public agencies seek to minimize accountability for welfare programming, integrating civic- and private-sector organizations in policy 
formation and implementation processes has served their interests. Uncoincidentally, these shifts reflect globally-mobile ideas advanced in the most resourced—and, like the US and UK, racially stratified—of countries, and are thus part of a global offloading of public responsibility for poverty onto private and voluntary actors.

Historically, the prominence of any given solution — whether it be marriage, employment, housing, or reconciliation with family — has been more telling of the agenda of the state, than with actual needs of individuals experiencing homelessness. This has been substantiated by social science in the US, UK, and Japan ${ }^{110}$ on homelessness regulation illustrating that rigid top-down approaches and gatekeeping practices associated with standardized measures like involuntary commitment (Failer 2002; Feldman 2004), warehousing people in shelters (Hopper and Baumohl 1994; Iwata 1985, 1995), the medicalization (Lyon-Callo 2004) and pathologization (Mills 2015) of homelessness and poverty, and the non-profit industrial complex (Willse 20015) tend to exacerbate problems rather than solve them (also Bretherton et al 2013; Collin 1984;. Cowan 2019; Iwata 2007; Kawano 1999; Shima 1999; Wasserman and Clair 2010; Yamada 2009). Against this background, policy narratives that imagine public, private, and civic sector agents as compassionate actors, in fact, justify and deflect critical analysis of social and political power imbalances that make these and other unilaterallyorganized actions and misrepresentations of policy need and effect possible.

\footnotetext{
${ }^{110}$ In Malaysia, little academic work has been done on federal approaches to addressing homelessness, much less critical work. However, an unpublished report by the Ministry of Welfare Services (1976) contains numerous critiques regarding the inefficacy of sweeps and detention as a solution to destitution, particularly in light of Malaysia's lack of preventative measures. Similarly, journalistic work critiquing government approaches, dating as far back as Dregs of Society (1981) have appeared from time to time.
} 
Less consideration is given to the interests and ideas of the least resourced-and most experientially knowledgeable_-actors: policy users. Instead, the posture of compassion stands as both cause and effect of the non-responsive-_and even antidemocratic nature — of homelessness regulation. It explains frustration and fatalism, as well as passive gratitude, expressed by people faced with policy in/action like Azleena, Kei, Thomas, and Taka as they have little choice but to carefully accommodate or resist policy approaches and goals set by the state. Moreover, policy designs that delegitimize_-in welfare and public order measures—-states of homelessness such that people are shut out from rights and protections mean only one thing: policy success necessarily complicates lives conducted while still homeless, including (but not limited to) those of the people that policy has already failed. This underscores how democratic systems and political rights are tied to survival, particularly where people cannot shape policies determining the course of their lives. Fukui, my one interviewee eager to see his actions shape policy through the process of a lawsuit, also stands as evidence of the paucity of options available to people interested in responsive, democratic governance. One of the many effects of homelessness is lacking access to the material and social resources necessary to pursue advance recognition and justice so often denied.

The truth is, as Willse (2015) has covered, in spite of many of their stated ideals and intentions, compassionate actors benefit from both security and insecurity, order and disorder. In neoliberal Japan, where universal protections and insurance programs are increasingly rolled back, security has been gradually commoditized for younger generations marketed today in the form of housing, for instance. Consequently, while middle- and upper-class households secure space in centrally located high-rise residential 
buildings, often found near commercial and leisure properties produced through redevelopment, persons experiencing homelessness are transferred to devalued housing stocks and properties through subsidized programs and livelihood assistance. That is, social programs benefit people seeking housing but also housing markets and propertyowners that would otherwise be disrupted by emergent trends.

In Malaysia, where foreign investment and work opportunities have expanded since the new international division of labor, swelling middle classes equating security with material wealth and health take on roles as compassionate actors re/distributing food, clothing, and services. These projects are funded, moreover, by upper classes interested in capitalizing on "social responsibility”. Stated differently, insecurity and disorder are addressed only in contexts that affect middle- and upper-class interests, rendering moot the experiences of people who are working-class or experiencing homelessness. Ultimately, austerity and the dismantling of social programs in Global North contexts like Japan, not only benefit compassionate actors economically, but also socially and politically through the powers it grants them over the insecure. Similarly, as disinvestment in Global North publics has led to increased flows of wealth to middle- and upper-class networks in the Global South, compassionate actors there, too, have become invested in these new global austerity economies.

The Unevenness of Democratic Power in the Present

Neoliberal-era regulation in both Tokyo and Kuala Lumpur has been profoundly shaped by the growing influence of middle-class social movements desirous of a more compassionate and just society—one reproduced in their image. Consequently, 
homelessness policies and programs in postindustrial Japan—and in Tokyo, in particular—have gradually shifted to housing-centric rather than employment-centric solutions in addition to rights-based protections like access to welfare assistance. However, at the same time, policy reform has also foregrounded public- and privatesector interest in market-based urban redevelopment, as seen in the widely heralded advance of public-private projects, and the integration of CSOs into infrastructure for policy implementation. Against this background, the government response to problems like everyday resistance to welfare uptake and the recurring "disappearances" of welfare recipients, as recorded in data, has tended towards public order measures that compel "homeless persons", defined in law as people living in public spaces, to accept welfare policies rather than directly address pinhane exploitation, abuse by service providers, and other factors underlying policy failure.

Homelessness policies and programs in Malaysia, a middle-income country, have increased access to practical protections and assistance - both in terms of liberties and aid—for persons experiencing homelessness, though these remain far from what would be considered a floor for social and economic security or an exit from homelessness. Nowhere has change in policy been more pronounced than in Malaysia's federally administered capital city, Kuala Lumpur. Here, as in Tokyo, new waves of public and civic assistance have emerged in a responsive but piecemeal fashion alongside attention to civic rights. Moreover, here too political will favors market-oriented urban planning, a programmatic reorganization of public order measures, and improved CSO participation in policy processes, rather than addressing extant gaps in assistance visible in resistance 
to shelters and high levels of flight from Desa Bina Diri, employment referral programs, and related institutions.

This restructuring of social infrastructure and urban management has profound implications for democracy in both countries. First, state propensity for directly integrating CSOs into policy formation and implementation processes has enabled not only an outsourcing of government accountability but also a sidelining of democratic processes that could or would otherwise be part of policy formation and oversight. In other words, a de-democratization of controls over public good (read: welfare) is taking place. Second, the marketization of public spaces—or public goods—also diminishes their democratic potential. That is, as private actors have enhanced claims to public space, the possibility of social and political representation shrinks. Such effects can be seen in the redevelopment of Miyashita Park in Tokyo and the configuration of a twomonth "boot camp" for people from Kuala Lumpur during the SEA Games. Relocation of Miyashita Park to the top of a 5-story mall not only undercuts open access to the park, particularly by non-consumer publics, but also the possibility of public assemblies, political protests, and other forms of democratic expression as parks serve as crucial venues for such events. In Kuala Lumpur, deference to private actors affiliated with the SEA Games (and, to a lesser degree, CSOs interested in providing aid) manifested in the one-off federal boot camp project, which sets yet another precedent for diminishing the constitutional rights of people experiencing homelessness in favor of programs advancing clearance in exchange for limited material and economic aid.

Cross-country studies of democratization across the twentieth century show that political stability and democratic potential are impossible without inclusionary political 
and social programs to address and reduce inequalities (Boix 2003; Hicks et al 1995). While programmatic governance contributes to long-term state stability, this alone cannot produce a functional democracy because wherever exclusionary political and social programs or processes emerge, these reduce democratic prospects and tip the scales towards inequitable, authoritarian regimes (Tilly 2007; Tudor and Slater 2015). Conventional liberal principles have limited democratic practice throughout the twentieth and twenty-first centuries by justifying the establishment and propagation of legal limitations on political participation, thereby preserving inequalities (Sigman and Lindberg 2019). In the case of homelessness regulation, too, policy structures have granted social, political, and economic rights only on a limited, conditional basisjustified as a means for ensuring conformity to contemporary socio-spatial codes, orders, and ideals. History reveals how these conditions, rather than serve the true interests of beneficiaries, undergird uneven power relations — and the foundation for pinhane exploitation and abuse—as policy agents are granted authority by law over persons with first-hand experience of homelessness.

Neoliberal welfare and public order measures—-like their pre-neoliberal predecessors—-work together to maximize social and spatial control in the interest of the economy. In the case of Tokyo, this has spurred the creation of new multi-agentic modes of micro-managing street homelessness under aims of clearing public space and filling underutilized housing stocks. In Kuala Lumpur, at present, management of street homelessness directs people into casual and low-income labor markets and props up an emergent non-profit industrial complex. These policies are intertwined with the neoliberal austerity politics of community and corporate social responsibility and 
compassion, which justify enclosures of collective space, a toughening of urban security, and the transfer of social infrastructure administration to voluntary, corporate, and quasigovernmental actors, all with negligible positive effect, if not dire consequences, for people who grapple with a lack of access to adequate protections and aid.

Inequalities that emerge from contemporary policy are just as much the product of exclusionary mechanisms inherent to policy and liberal governance, designed as it was amidst regimes of imperial rule, as they are distinctly neoliberal. Effectively reducing and eliminating inequalities and injustices that endanger the survival of marginalized social groups requires a reorganization of welfare and public order systems that also simultaneously resists implicit or explicit romanticization of pre-neoliberal imperial or postwar models. Regulation cannot be improved without undoing the socio-legal entanglements, and legacies of empire, that deprive people experiencing homelessness of "full personhood" (Feldman 2004) and social and political autonomy. True democratic governance and effective solutions to homelessness both require that people have unconditional access political and social space and voice while they are homeless.

Historically and today, homelessness has been (re)constructed as a problem of social and spatial disorder threatening spiritual and material modernity. While particular policy ideas and institutions reflecting the post/colonial and post/imperial political economy of Kuala Lumpur and Tokyo, respectively, have changed over time, the fundamental delegitimization of homelessness across multiple policy fields stands as the primary legacy of vagrancy laws: effectively rendering homelessness grounds for criminalization, eviction and sweeps, public assistance disqualification, and political disenfranchisement, among other things. Recent policy innovations have relied heavily 
on legal frameworks that classify homelessness as an illegitimate—and, hence, unprotected—state of existence. The problems posed by these policy systems hamper our collective ability to resolve homelessness and weaken democratic governance itself.

To resolve homelessness, there is a critical need for better democratic systems, and not just technical fixes, in policy solutions. In light of this, addressing homelessness in a democratic and humane manner requires its full legalization and formal public recognition as not an aberration but an unexceptional variation in modern distributions of wealth and power. There is an urgent need for a reckoning with the role of homelessness regulation in processes underlying dispossession and urbanization, along with clear interventions to ensure that the political and social rights, dignity, and human securities of persons with experience of homelessness are recognized and restored so that, by extension, they are no longer barred from contributing to authentic change. 


\section{LIST OF REFERENCES}

Adler, J.S. (1989). A Historical Analysis of the Law of Vagrancy. Criminology, 27(2), 209-229.

Agamben, G. (1998). Homo Sacer: Sovereign Power and Bare Life. Stanford University Press.

Akaishi, K. (1982). Jukkyū-Kizoku no Seiritsu [Enacting Poor Relief Regulation]. Waseda-Hō-Daigaku, 57(39):301-344.

Akiba, T. (1959). Seikatsu-Hogohō ni Okeru Jiritsu Jochō no Mondai [Problems in SelfReliance and Welfare]. Seikatsu to Fukushi, 45:18-19.

Allison, A. (2014). Precarious Japan. Duke University Press.

Amamiya, K. (2007). Ikisasero! Nanminka suru wakamono-tachi [Let us live! Today's Youth as Refugees]. Tokyo: Ōtashuppan.

Aoki, H. (1989). Yoseba Rōdōsha no Sei to Shi [The Lives and Deaths of Yoseba Laborers]. Akashi Shoten.

Aoki, H. (2010). Haijo suru Kindai [The Modern Era of Exclusion]. In Aoki, H. (ed.), Hōmuresu Sutadiizu -Haijo to Hōsetsu no Genjitsu [Homeless Studies: Reality of Exclusion and Inclusion]. Minerva Shobo

Arendt, H. (1965). On Revolution. Penguin Books.

Aspengren, H. (2013). Empire: A Question of Hearts? The Social Turn in Colonial Government, Bombay c.1905-1925. In Duffield, M. and Hewitt, V. (eds.) Empire, development and colonialism: the past in the present, pp. 45-58. HSRC Press.

Baker, T., Smith, M.P., Roy, A., McCann, E., McGuirk, P., Mountz, A., Peck, J., Theodore, N. (2016). Reading Jamie Peck and Nik Theodore's Fast Policy. Political Geography, 53:89-99.

Bassuk, E. and Franklin, D. (1992). Homelessness Past and Present: The Case of the United States, 1890-1925. New England Journal of Public Policy, 8(1):67-85.

Baxstrom, R. (2000). Governmentality, Bio-Power and the Emergence of the MalayanTamil Subject on the Plantations of Colonial Malaya. Crossroads: An Interdisciplinary Journal of Southeast Asian Studies, 14(2):49-78.

Bayliss, J. (2013). On the Margins of Empire. Harvard University Press 
Bayly, C.A. (2004). The Birth of the Modern World:1780-1914. Blackwell.

Beckett, K. and Herbert, S. (2010). Banished: The new social control in urban America. Oxford University Press.

Begging Bares Root of Vagrancy Problems. (1979). New Straits Times, December 21, p.8.

Beier, A.L. (1974). Vagrants and the social order in Elizabethan England. Past and Present, 64:3-29.

Beier, A.L. and Ocobock, P. (eds.) (2008). Cast Out: Vagrancy and Homelessness in Global and Historical Perspective. Ohio University.

Beier, A. (1986). Masterless Men: The Vagrancy Problem in England, 1560-1640. Methuen.

Belfield, H. (1904). The Vagrant Ward, January 30.[R.G.O.736/04]. File\#1957/0583982. Arkib Negara Malaysia.

Bell, E. (2010). Anglo-Saxon Sociologies of the Punitive Turn: A Reply. Champ pénal (Penal field), Vol.VII.

Benton, L.A. (1996). From World Systems Perspective to Institutional History. Journal of World History 7(2): 261-295.

Benton , L.A. (2002). Law and Colonial Cultures: Legal Regimes in World History, 1400-1900. Cambridge University Press.

Benton, L.A. (2016). Rage for Order. Harvard University Press.

Bhabha, H.K. (1984). The Other Question: Difference, Discrimination and the Discourse of Colonialism. In Barker, F. et al. (eds.) Literature, Politics, and Theory (pp. 148172). Methuen.

Bhabha, H.K. (1994). The Location of Culture. Routledge.

Bhambra, G. (2007). Rethinking modernity: Postcolonialism and the sociological imagination. Springer.

Bhambra, G.K. (2010). Historical Sociology, International Relations and Connected Histories. Cambridge Review of International Affairs, 23(1): 127-143.

Bernama. (2017, August 1). Gelandangan KL Sertai Program Bantu Kehidupan. Retrieved from Perak Today: https://peraktoday.com.my/2017/08/gelandangan-klsertai-program-bantu-kehidupan/ 
Black, D. (1993). The Social Structure of Right and Wrong. Academic Press.

Blaut, J. (1970). Geographic Models of Imperialism. Antipode, 2(1):65-82.

Borchard, K. (2012). Ethics and Studying Homelessness: Tales from the Field. In Valado, T. (Ed.), Professional lives, personal struggles: Ethics and advocacy in research on homelessness. Lexington Books.

Botsman, D. (2005). Punishment and Power: The Making of Modern Japan. Princeton University Press.

Braddell, R. S. (1921). Law and Crime. In Braddell, R.S. One hundred years of Singapore : being some account of the capital of the Straits Settlements from its foundation by Sir Stamford Raffles on the 6th February 1819 to the 6th February 1919 (pp. 160-290). Murray.

Bretherton, J., Hunter, C., and Johnsen, S. (2013). "You Can Judge Them on How They Look ... ": Homelessness Officers, Medical Evidence and Decision-making in England European Journal of Homelessness, 7(1):69-92.

Bunnell, T. (1999). Views from above and below: the Petronas Twin Towers and/in contesting visions of development in contemporary Malaysia. Singapore Journal of Tropical Geography, 20(1), 1-23.

Bunnell, T., Barter, T.A., Morshidi,S. (2002). Kuala Lumpur Metropolitan Area. Cities, 19(5):357-370.

Bunnell, T. (2002). Cities for Nations? International Journal of Urban and Regional Research, 26(2):284-298.

Bunnell, T. (2004). Re-viewing the Entrapment controversy. GeoJournal, 59:297-305.

Bunnell, T. (2015). Antecedent Cities and Inter-referencing Effects. Urban Studies, 52(11):1983-2000.

Bureau of Social Welfare and Public Health. (2004). Shisetsubetsu Gaisu Chōsa Ichiran (Heisei 16 2gatsu). Retrieved from:

https://www.fukushihoken.metro.tokyo.lg.jp/seikatsu/rojo/gaisuchosa.files/H16.2. pdf

Bureau of Social Welfare and Public Health. (2015, March 12). Rōjō Seikatsusha Chi'ikibetsu Gaisu Chōsa Ichiran (Heisei 27 1gatsu). Retrieved from https://www.metro.tokyo.lg.jp/tosei/hodohappyo/press/2015/04/60p4s201.html

Bureau of Social Welfare and Public Health. (2019a, March 11). Rōjō Seikatsusha Shisetsubetsu Gaisu Chōsa Ichiran (Heisei 31 1-gatsu). Retrieved from 
https://www.metro.tokyo.lg.jp/tosei/hodohappyo/press/2019/04/26/documents/03 _02.pdf

Bureau of Social Welfare and Public Health. (2019b). Rōjō Seikatsusha Chi'ikibetsu Gaisu Chōsa Ichiran (Heisei 31 1gatsu). Retrieved from Bureau of Social Welfare and Public Health:

https://www.metro.tokyo.lg.jp/tosei/hodohappyo/press/2019/04/26/documents/03 _01.pdf

Burton, A. and Ocobock, P. (2008). The "Travelling Native": Vagrancy and Colonial Control in British East Africa. In Beier, A.L. and Ocobock, P. (eds.) Cast Out: Vagrancy and Homelessness in Global and Historical Perspective (pp. 270-301). Ohio University.

Cain, P.J. and. Hopkins, A.G. (1993). British Imperialism: Innovation and Expansion, 1688-1914. Longman.

Chakrabarty, D. (2000). Provincializing Europe: Postcolonial Thought and Historical Difference. Princeton University Press.

Chamayou, G. (2012). Manhunts: A Philosophical History. Princeton University Press.

Chambliss, W.J. (1964). A Sociological Analysis of the Law of Vagrancy. Social Problems, 12(1):67-77.

Chatterjee, P. (1993). The Nation and Its Fragments: Colonial and Postcolonial Histories. Princeton University Press.

Choo, K. (1925). Correspondence, January 21 [Sel.450/25]. File\#1957/0234368. Arkib Negara Malaysia.

Christy, R. (2004). The Making of Imperial Subjects in Okinawa. In Weiner, M. (ed.) Race, Ethnicity and Migration in Modern Japan (pp. 173-198). Routledge.

City after Night. (2014, May 17). Retrieved from Malay Mail.

Clapham, D. (2007). Homelessness and Social Exclusion. In: Abrams, D. Christian, J. and Gordon, D. (eds.) Multidisciplinary Handbook of Social Exclusion Research. (pp. 79-94). John Wiley and Sons, Ltd.

Clearing Asakusa Park [Asakusa Kōen no Furōsha Issō] (1931). Tōkyō-shi Kōhō. July 2.

Clement, P.F. (1983). The Transformation of the Wandering Poor in Nineteenth-century Philadelphia. In Monkkonen, E.H. (ed.) Walking to Work: Tramps in America, 1790-1935. University of Nebraska Press. 
Cloke, P., May, J., and Johnsen, S. (2010). Swept up lives? Re-envisioning the homeless city. Wiley-Blackwell.

Collin, R.W. (1984). Homelessness: The Policy and the Law. The Urban Lawyer, 16(2):317-329.

Comaroff, J.L. (1998). Reflections on the Colonial State, in South Africa and Elsewhere: Factions, Fragments, Facts and Fictions. Social Identities, 4(3):321-361.

Comaroff, J.L. (2001). Introduction: Colonialism, Culture, and the Law: A Foreword. Law and Social Inquiry, 26(2):305-314.

Comaroff, J. and Comaroff, J. (2006). Law and Disorder in the Postcolony: An Introduction. In: Comaroff, J. and Comaroff, J. (eds.) Law and Disorder in the Postcolony. University of Chicago Press.

Connell, R.W. (1997). Why Is Classical Theory Classical? The American Journal of Sociology, 102(6):1511-1557.

Connell, R. (2007). Southern Theory: The Global Dynamics of Knowledge in Social Science. Polity Press.

Cook, T., and Braithwaite, G. (1979). The Problem for Whom? In Cook, T. (ed.) Vagrancy: Some New Perspectives. Academic Press.

Cooper, F. 2005. Colonialism in Question: Theory, Knowledge, and History. University of California Press.

Cover, R. (1986). Violence and the Word. Yale Law Journal, 95(8):1601-1629.

Cowan, D. (2019). Reducing Homelessness or Re-ordering the Deckchairs? The Modern Law Review, 82: 105-128.

Cresswell, T. (2001). The Tramp in America. Reaktion.

Daniels, C.W. (1906) Studies from the Institute for Medical Research:Vol.4. Beri Beri. Institute for Medical Research.

Das, D.K. and Verma, A. (1998). The Armed Police in the British Colonial Tradition: The Indian perspective. Policing, 21(2):354-367.

Daston, L. and Galison, P. (2007). Objectivity. Zone Books.

David, E. (1950). Federal Secretariat Circular No.34 [F.S.O.1709/49], December 20. File\#1957/0345908. Arkib Negara Malaysia. 
Davis, D.E. (2005). Cities in Global Context: A Brief Intellectual History. International Journal of Urban and Regional Research, 29(1):92-109.

Degerman, D. (2019). Within the heart's darkness: The role of emotions in Arendt's political thought. European Journal of Political Theory, 18 (2):153-173.

Dej, E. (2016). Psychocentrism and Homelessness: The Pathologization/Responsibilization Paradox. Studies in Social Justice, 10(1):117135.

DeVerteuil, G. (2006). The Local State and Homeless Shelters: Beyond revanchism? Cities, 23:109-120.

DeVerteuil, G., May, J., and Von Mahs, J. (2009). Complexity Not Collapse: recasting the geographies of homelessness in a 'punitive' age. Progress in Human Geography, 33(5):646-666.

DeVerteuil, G. (2012). Does the Punitive Need the Supportive? Antipode, 46(4):874-893.

Dewan Rakyat. (1973, July 23). Pengemis di Kaki-kaki Lima. Malaysian Parliament website. Retrieved from:www.parlimen.gov.my/files/opindex/pdf/AUMDR24071973.pdf.

Dikotter, F. (1997). Introduction. In Dikotter, F. (ed.) The Construction of Racial Identities in China and Japan (pp. 1-11). University of Hawaii Press.

Doherty, J., Busch-Geertsema,V., Karpuskiene,V, Korhonen,J., O’Sullivan,E., Sahlin,I., Tosi,A., Petrillo, A., and Wygnańska, J. (2008). Homelessness and Exclusion. Surveillance and Society, 5(3):290-314.

Dohi, M. (1994). Edo-kara Tōkyō heno Hinmin-Shūyō no Seidoteki-Henka to ToshiŌpensupēsu no Henka ni Kansuru Kansatsu [Change in Relief and Open Spaces during Edo-Tokyo Transition]. Zoen Zasshi, 57(5):55-60.

Dowden, R. (1927, November 9). Memorandum [Sel.4916/24]. File\#1957/0250395. Arkib Negara Malaysia.

Dregs of Society. (1981). New Sunday Times, October 4, p.3.

Driscoll, M. (2010). Absolute Erotic, Absolute Grotesque: The Living, Dead, and Undead in Japan's Imperialism, 1895-1945. Duke University Press.

Dubber, M.K. (2005). The Police Power: Patriarchy and the Foundations of American Government. Columbia University Press.

Duffield, M. (2008). Global Civil War. Journal of Refugee Studies, 21(2):145-165. 
Duffield, M. and Hewitt, V. (2013). Introduction. In Duffield, M. and Hewitt, V. (eds.) Empire, Development and Colonialism: The past in the present (pp. 1-15). HSRC Press.

Durkheim, E. (1984). The Division of Labor in Society (trans by W.D. Halls). Free Press. Eguchi, E. (1979). San'ya. Miraisha

Emerson, R. (1964). Malaysia: A Study in Direct and Indirect Rule. University of Malaya Press.

Esping-Andersen, G. (1990). The Three Worlds of Welfare Capitalism. Polity Press.

Escobar, A. (1995). Encountering Development: The making and unmaking of the Third World. Princeton University Press.

Elliott, J. (1957, July 4). Beggars [Sel.Sec.2014]. File\#2001/0069879. Arkib Negara Malaysia.

Failer, J.L. (2002). Who Qualifies for Rights?: Homelessness, Mental Illness, and Civil Commitment. Cornell University Press.

Fassin, D. (2015). At the Heart of the State. The Moral World of Institutions. Pluto.

Feldman, L.C. (2004). Citizens Without Shelter. Cornell University Press.

Ferguson, J. (2006). Global Shadows: Africa in the Neoliberal World Order. Duke University Press.

Fiennes, J. (1962). Vagrancy Act, October 8. File\#1990/0006344. Arkib Negara Malaysia.

Finfgeld-Connett, D. (2014). Content Analysis for Knowledge-building and Theorygenerating Qualitative Systematic Reviews. Qualitative Research, 14(3):341-352.

Fischer-Tine, H. (2005). Britain’s Other Civilising Mission: Class prejudice, European loaferism and the workhouse-system in colonial India. The Indian Economic and Social History Review, 42(3):295-338.

Fitzgerald, R. (1934, May 17). Accommodation [N.S.G.626/34]. File\#1957/0455497. Arkib Negara Malaysia.

Foucault, M. (1977). Discipline and Punish. Penguin.

Foucault, M. (1978). The History of Sexuality. Pantheon Books.

Foucault, M. (1980). Power/Knowledge. Pantheon. 
Foucault, M. (1988). Madness and Civilization: A History of Insanity in the Age of Reason. Vintage Books.

Foucault, M. (1998). The Will to Knowledge: The History of Sexuality Volume 1 (trans. R Hurley). Penguin.

Foucault, M. (2004). The Birth of Biopolitics - Lectures at the Collège de France 197879 (transl. by Graham Burchell). Palgrave Macmillan.

Foucault, M. (2008). "Society Must Be Defended”. Lectures at the Collège de France, 1975-76 (transl. by David Macey). Palgrave Macmillan.

Fowler, E. (1996). San'ya Blues. Cornell University Press.

Frank, A.G. (1966). The Development of Underdevelopment of Latin America: Underdevelopment or Revolution. Monthly Review Press.

Fraser, N. (1989). Unruly Practices: Power, Discourse, and Gender in Contemporary Social Theory. University of Minnesota Press.

Friedman, T.L. (2005). The world is flat: A brief history of the twenty-first century. Farrar, Straus and Giroux.

Fujitani, T. (2011). Race for Empire: Koreans as Japanese and Japanese as Americans during World War II. University of California Press.

Furusawa, T (1955) Furōsha-Mondai ni Tsuite no Kantanna Kōryō [Consideration of Vagrancy].Toshi-Mondai, 46(2):218-225

Galaiou, K. (2018). Neoliberalism and Labour Inequality in Japan. Leiden University: Masters Thesis.

Ganachari, A. (2002). 'White Man's Embarrassment' European Vagrancy in nineteenth Century Bombay. Economic and Political Weekly, 37(25):2477-2486

Garland, D. (1985). Punishment and Welfare: A History of Penal Strategies. Gower.

Garland, D. (2001). The Culture of Control. Oxford University Press.

Garon, S. (1998). Molding Japanese Minds: The State in Everyday Life. Princeton University Press.

Gatrell, V.A.C. (1996). The Hanging Tree: Execution And The English People 17701868. Oxford University Press.

Giddens, A. (1990). The Consequences of Modernity. Polity Press. 
Gill, T. (2001). Men of Uncertainty: The Social Organization of Day Laborers in Contemporary Japan. State University of New York Press.

GlobalCapital. (2007). Japan's municipal bond revolution. Retrieved from GlobalCapital website at: https://www.globalcapital.com/article/k53f9dh29nrs/japans-municipalbond-revolution

Go, J. (2008). Global Fields and Imperial Forms. Sociological Theory, 26(3):201-229.

Go, J. (2012). Letter from the Chair: Globalizing Comparative-Historical Sociology. Trajectories: Newsletter of the ASA Comparative-Historical Sociology Section (online at http://www2.asanet.org/sectionchs/newsletter/)

Go, J. (2013). “For a Postcolonial Sociology.” Theory and Society. 42(1):25-55.

Go, J. (2008). Global Fields and Imperial Forms. Sociological Theory, 26(3):201-229.

Go, J. (2016). Globalizing Sociology, Turning South. Sociologica, 2/2016:0-0

Gowan, T. (2010). Hobos, Hustlers, and Backsliders: Homeless in San Francisco. University of Minnesota Press.

Greene, J. (2014). Managing poverty, managing dissent: homeless politics and collective action in London. Policy and Politics, 42(3):315-331.

Grosfuguel, R. (2008). World-System Analysis and Postcolonial Studies: A Call for a Dialogue from the "Coloniality of Power" Approach. In Krishnaswamy, R. and Hawley, J.C. (eds.) The Post-Colonial and the Global (pp. 94-104). University of Minnesota Press.

Haggard, R. F. (2001). The Persistence of Victorian Liberalism: The Politics of Social Reform in Britain, 1870-1900. Greenwood Press.

Halperin, S. (2004). War and Social Change in Modern Europe: The Great Transformation Revisited. Cambridge University Press.

Halperin, S. (2015). Imperial City States, National States, and Post-National Spatialities. In Halperin, S. and Palan, R. (eds.) Legacies of Empire: Imperial Roots of the Contemporary Global Order (pp. 69-96). Cambridge University Press.

Hane, M. (2016). Peasants, Rebels, and Outcasts: The Underside of Modern Japan. Rowman and Littlefield.

Haney, L. and Pollard, L. (2003). Introduction: In a Family Way: Theorizing State and Familial Relations. In Haney, L. and Pollard, L. (eds.) Families of a New World: Gender, Politics, and State Development in a Global Context (pp. 1-14). Routledge. 
Hansen, A. (2007). Exhibiting Vagrancy, 1851: Victorian London and the "Vagabond Savage". In Phillips, Lawrence A., A Mighty Mass of Brick and Smoke: Victorian and Edwardian Representations of London (pp. 61-84). Rodopi.

Haraguchi, T. (2016). Sakebi no Toshi [Cry of the City]. Rakuhoku Shuppan

Harcourt, B.E. (1998). Reflecting on the Subject: A Critique of the Social Influence Conception of Deterrence, the Broken Windows Theory, and Order-Maintenance Policing New York Style. Michigan Law Review, 97(2):291-389

Harcourt, B. (2010). Neoliberal Penality: A Brief Genealogy. Theoretical Criminology, 14(1):1-19.

Hare, G. (1897). Erection of a Ward for Vagrants, December 12. File\#1957/0076302. Arkib Negara Malaysia.

Hansen, A (2007). Exhibiting Vagrancy, 1851. In Phillips, LA.(ed.) A Mighty Mass of Brick and Smoke, 61-84. Rodopi.

Harrison, M.L. (1999). Theorising homelessness and "race". In Kennett, P. and Marsh, A. (eds.) Homelessness - Exploring the New Terrain (pp. 101-122). The Policy Press.

Hartog, J. (1972). The intervention system for mental and social deviants in Malaysia. Social Science and Medicine, 6:211-220.

Harvey, D. (1989). The Condition of Postmodernity: An Enquiry into the Origins of Cultural Change. Blackwell.

Hasegawa, M. (2005). Economic Globalization and Homelessness in Japan. American Behavioral Scientist, 48:989-1012.

Hasegawa, M. (2006). We are Not Garbage!. Routledge.

Hay, D. and Craven, P. (1993). Master and Servant in England and the Empire: A Comparative Study. Labour / Le Travail, 31:175-184.

Hay, D. and Craven, P. (2004). Masters, Servants, and Magistrates in Britain and the Empire, 1562-1955. University of North Carolina.

Hayashi, M. (2015). Rescaled "Rebel Cities”, Nationalization, and Bourgeois Utopia. Antipode, 47(2):418-441.

Hennigan, B. and Speer, J. (2018). Compassionate revanchism. Urban Studies, 56(5):906-921. 
Herbert, S. and Brown, E. (2006). Conceptions of Space and Crime in the Punitive Neoliberal City. Antipode, 38(4):755-777.

Herbert, S. (1997). Policing Space: Territoriality and the Los Angeles Police Department. University of Minnesota Press.

Herbert, S and Beckett, K. (2010). 'This is home for us': questioning banishment from the ground up. Social and Cultural Geography, 11(3):231-245.

Hirayama, Y. (2013). Public Housing and Neoliberal Policy in Japan. In S. M. Chen J., The Future of Public Housing (pp. 143-161). Springer.

Hiro-Chusa Hyoei. (1913). Hinmin-Seido narabini Kyūsai-Jigyō. Kangoku Kyōkai

Hirota, M. (1998). Sabetsu no shisen: kindai Nihon no ishiki kōzō [The Gaze of Discrimination: On the Structure of Modern Japan’s Consciousness]. Yoshikawa Bunkan.

Hirschman, C. (1986). The Making of Race in Colonial Malaya: Political economy and racial ideology. Sociological Forum, 1(2):330-361.

Holloway, T.H. (2008). Doing Favors for Street People: Official Responses to Beggars and Vagrants in Nineteenth Century Rio de Janero. In Beier, A.L. and Ocobock, P. (eds.) Cast Out: Vagrancy and Homelessness in Global and Historical Perspective (pp. 162-183). Ohio University.

Home, R. (1997). Of Planting and Planning. E and FN Spon.

Honig, B. (1994). Difference, Dilemmas, and the Politics of Home. Social Research, 61(3):563-597.

Hopper, K. and Baumohl, J. (2014) Held in abeyance: rethinking homelessness and advocacy. American Behavioral Scientist, 37(4).

Housing First Kenkyūkai. (2013). Tōkyō-to Hōmuresu Chi'iki Seikatsu Ikō Shien Jigyō 2004-2009: Jiritsu Shien to Ketsugō shita Haujingu Fāsuto Apurōchi ni Chakumoku shita Bunseki. Research report by Akiko Nakashima, Michiko Bando, Gen Ozaki, Yutaka Maruyama, and Yasue Suzuki.

Howell, D.L. (2005). Geographies of Identity in Nineteenth-Century Japan. University of California Press

Huggins, M. (1985). From Slavery to Vagrancy in Brazil: Crime and Social Control in the Third World. Rutgers University Press.

Hunt, A. (1993). Explorations in law and society: Toward a constitutive theory of law. Routledge. 
Hussain, N. (2003). The Jurisprudence of Emergency: Colonialism and the Rule of Law. The University of Michigan Press.

Iida, Y. (2002). Rethinking Identity in Modern Japan: Nationalism as aesthetics. Routledge.

Inaba, N., Ogawa, T. and Suzuki, N. (2018). The Right to Adequate Housing: Evictions of the homeless and the elderly caused by the 2020 Summer Olympics in Tokyo. Leisure Studies, 37(1):89 - 96.

Ishikawa, M. (2007). Tōkyō-Orinpikku-Jitsugen ni Mukete no Yotsu-no-Senryaku [Four Strategies for a Tokyo Olympics]. Tōken Geppō, 2(706)

Iwata, M. (1985). Sengō Seikatsu Hogohō no Keisei-Teichaku to Seikatsu Hogo Shisetsu [Welfare Institutions under the Daily Life Security Law in the Post War Era]. Jinbun-Gakuhō, 179:165-193.

Iwata, M. (1992). Shakai Fukushi to Ijū no Fuantei [Housing Insecurity and Welfare]. Jinbun-Gakuhō, 233:19-59.

Iwata, M. (1995). Sengō Shakai Fukushi no Tenkai to Daitoshi-Saiteihen [Postwar Welfare and Urban Underclasses]. Minerva Shobo.

Iwata, M. (2007). Gendai no Hinkon: Wākingu Pūa/Homuresu/Seikatsu Hogo. Chikuma Shobo.

Jacobs, A.M. (2015). Process-tracing the Effects of Ideas. In Bennett, A. and Checkel, J.T. (eds.), Process Tracing in the Social Sciences: From Metaphor to Analytic Tool. Cambridge University Press.

Japan College of Social Work. (1960). Nihon no Kyūhin-Seido. Keiso Shobo.

Jessop, B. (2015). Hard cash, easy credit, fictitious capital: Critical reflections on money as a fetishised social relation. Finance and Society, 1(1):20-37.

Jisseki Hyokasho. (2005, August). Retrieved from Ministry of Health, Labour, ad Welfare: https://www.mhlw.go.jp/wp/seisaku/jigyou/05jisseki/7-2-2.html

Johnsen, S. and Fitzpatrick, S. (2010). Revanchist Sanitisation or Coercive Care? Urban Studies, 47(8):1703-1723.

Kahan, D.M. (1997). Social Influence, Social Meaning, and Deterrence. Virginia Law Review 83: 349-395.

Kaika, M. (2017). Between compassion and racism: how the biopolitics of neoliberal welfare turns citizens into affective 'idiots'. European Planning Studies, 25(8):1275-1291. 
Kato, D. (2015). Liberalizing Lynching: Building a New Racialized State. Oxford University Press.

Kaur, A. (2010). Labour migration trends and policy challenges in Southeast Asia. Policy and Society, 29(4):385-397.

Kawano, Y. (1999). Nojukusha wo Kyotaku Hogo Seyo. Chingin to Shakai-Hōshō, 1249:46-51.

Kelly, J. and Kaplan, M. (2004). My Ambition is Much Higher than Independence. In Duara (ed.) Decolonization (pp.131-151). Taylor and Francis.

Kennedy, S.M. (2016). Urban policy mobilities, argumentation and the case of the model city. Urban Geography, 37(1):96-116.

Khoo, B.T. and Loh, K.W.F. (2002). Introduction. In Khoo, B.T. and Loh, K.W.F. (eds.), Democracy in Malaysia (pp.1-18). Curzon Press.

Kiddey, R. (2017). Homeless Heritage: Collaborative Social Archaeology as Therapeutic Practice. Oxford.

King, A.D. (1976). Colonial Urban Development. Routledge and Kegan Paul.

King, A.D. (1990). Urbanism, Colonialism and the World Economy. Routledge.

Kingston, J. (2012). Contemporary Japan: History, Politics, and Social Change since the 1980s. Wiley.

Kinzley, W. (1988). Japan's Discovery of Poverty: Changing Views of Poverty and Social Welfare in the Nineteenth Century. Journal of Asian History, 22(1):1-24.

Kirkpatrick, L.O. (2017). The New Urban Fiscal Crisis: Finance, Democracy, and Municipal Debt. Politics \& Society, 44(1):45-80.

Kitagawa, Y. (2010). Hōmuresu to Shakaiteki-Haijo [The Homeless and Social Exclusion]. Riron to Dōtai, 3:71-86.

Kitaura, T. (1913). Tōto Furō-Nikki [East Tokyo Vagrant’s Diary]. Subunkan Shoten.

Knox, P.L. (1995). Introduction. In Knox, P.L. and Taylor, P.J. (eds.), World Cities in a World-system (pp.3-20). Cambridge University Press.

Komori, Y. (2001). Posuto-koroniaru [Postcolonial]. Iwanami Shoten.

Koto, E. (1933). Furōsha wo Kataru [On Vagrants]. Daidokan Shoten. 
Krishnaswamy, R. (2008). Postcolonial and Globalization Studies: Connections, Conflicts, Complicities. In Krishnaswamy, R. and Hawley, J.C. (eds.) The PostColonial and the Global (pp. 2-21). University of Minnesota Press.

Ishizuka, H. (1977). Tōkyō no Shakai Keizai Shi: Shihonshugi to Toshi Mondai [The socio-economic history of Tokyo: capitalism and the urban problem]. Kinokuniya Shoten

Jabatan Kebajikan Masyarakat [Social Welfare Department]. (2012). Laporan Statistik 2011 Bhg. B 9 - Orang Papa [2011 Statistics Report Dept B 9 Destitute Persons]. Retrieved from Jabatan Kebajikan Masyarakat: http://www.jkm.gov.my/jkm/uploads/files/pdf/laporan_statistik/statistic_2011/BH G\%20B\%209\%20-\%20ORANG\%20PAPA.pdf

Jabatan Kebajikan Masyarakat [Social Welfare Department]. (2013). Laporan Statistik 2012 Bhg. B 9 - Orang Papa [2012 Statistics Report Dept B 9 Destitute Persons]. Retrieved from Jabatan Kebajikan Masyarakat: http://www.jkm.gov.my/jkm/uploads/files/pdf/laporan_statistik/statistic_2012/BH G\%20B\%209\%20-\%20AOP.pdf

Jabatan Kebajikan Masyarakat [Social Welfare Department]. (2014). Laporan Statistik 2013 Bhg. B 9 - Orang Papa [2013 Statistics Report Dept B 9 Destitute Persons]. Retrieved from Jabatan Kebajikan Masyarakat: http://www.jkm.gov.my/jkm/uploads/files/pdf/laporan_statistik/statistic_2013/BH G_B_9-AOP.pdf

Jabatan Kebajikan Masyarakat [Social Welfare Department]. (2015). Laporan Statistik 2014 [2014 Statistics Report]. Retrieved from Jabatan Kebajikan Masyarakat: http://www.jkm.gov.my/jkm/uploads/files/pdf/Buku\%20JKM\%202014.pdf

Jabatan Kebajikan Masyarakat [Social Welfare Department]. (2016). Laporan Statistik 2015 [2015 Statistics Report]. Retrieved from Jabatan Kebajikan Masyarakat: http://www.jkm.gov.my/jkm/uploads/files/penerbitan/Buku\%20JKM\%202015\%E 2\%80\%A2Final.pdf

Jabatan Kebajikan Masyarakat [Social Welfare Department]. (2017). Laporan Statistik 2016 [2016 Statistics Report]. Jabatan Kebajikan Masyarakat. Retrieved from Jabatan Kebajikan Masyarakat: http://www.jkm.gov.my/jkm/uploads/files/penerbitan/Buku\%20statistik\%202016. pdf

Jabatan Kebajikan Masyarakat [Social Welfare Department]. (2018). Laporan Statistik 2017 [2017 Statistics Report]. Jabatan Kebajikan Masyarakat. Retrieved from Jabatan Kebajikan Masyarakat: http://www.jkm.gov.my/jkm/uploads/files/Bahagian\%20Kawalan\%20Standard/O 
P\%E2\%80\%A2Latest\%20FINAL\%E2\%80\%A2Buku\%20Laporan\%20Statistik\% 202017\%20JKM(1).pdf

Jomo K.S. and Gomez, E.T. (2000). The Malaysian Development Dilemma. In Mushtaq H. Khan and Jomo K. S. (eds.), Rents, Rent-Seeking and Economic Development: Theory and Evidence in Asia (pp. 274-303). Cambridge University Press.

Kapoor, I. (2008). The postcolonial politics of development. Routledge.

Kozawa, Y. (1955). Furōsha Mondai ni Tsuite no Kantan-na Kōryō - Iwayuru Putaro no Jittai wo Chūshin to Shite [A Basic Consideration of the Vagrant Problem: Concerning the Truth about So-called "Putaro"]. Toshi-Mondai, 46(2):218-225.

Kubota, A. (2009). Rōjō-Seikatsu-sha Shien-to Jūtaku-Seisaku ni-Okeru HaujinguFāsuto-no Donyū-ni Mukete [Housing-First Approaches in Assistance and Housing Policy]. Toshi-Keikakuron Bunshū, 44(3):715-720.

Lange, M. (2013). Comparative-Historical Methods. London: SAGE Publications Ltd.

Larner, W. (2000). Neoliberalism: Policy, Ideology, Governmentality. Studies in Political Economy, 63(1):5-25.

Laurenson, P. and Collins, D. (2006). Beyond Punitive Regulations? New Zealand local government responses to homelessness. Antipode, 39: 649-667.

Lawton, P. (2018). Situating Revanchism in the Contemporary City. City, 22(5-6):867874.

Lazonick, W. (1974). Karl Marx and Enclosures in England. Review of Radical Political Economics, 6(2):1-59.

Legg, S. (2005). Foucault's population geographies. Population, Space and Place, 11(3):137-156.

Leonard, J. (1995). Foucault and (the Ideology of) Genealogical Legal Theory. In: Leonard, J. (ed.), Legal Studies as Cultural Studies: A Reader in (Post)Modern Critical Theory (pp. 133-51). SUNY Press.

Leong, W. (1977, September 1). Akta Orang-Orang Papa. File\#2007/0047368. Arkib Negara Malaysia.

Lepawsky, J. and Jubilado, R. (2014). Globalising Kuala Lumpur and Rationalising the Street: Hawkers and the Aporias of Urban Renewal along Petaling Street and Jalan Masjid India.In Yeoh, S.G. (ed.) The Other Kuala Lumpur: Living in the Shadows of a Globalising Southeast Asian City (pp. 22-40). Routledge. 
Lessig, L. (2005). The Regulation of Social Meaning, University of Chicago Law Review, 943: 1039-40.

Lim, H. K. (1978). The Evolution of the Urban System in Malaya. University of Malaya Press.

Lim, M. (1970, August 6). Masa'alah Pengemis2. File\#1989/0009985. Arkib Negara Malaysia.

Lowe, L. (2015). The Intimacies of Four Continents. Duke University Press Books.

Lynteris, C. (2011). From Prussia to China: Japanese Colonial Medicine and Gotō Shinpei's Combination of Medical Police and Local Self-Administration. Medical History, 55(3): 343-347.

Lyon-Callo, V. (2004). Inequality, Poverty, And Neoliberal Governance: Activist Ethnography in the Homeless Sheltering Industry. University of Toronto Press.

MacPherson, S. (1982). Social Policy in the Third World: The Dilemma of Underdevelopment. Wheatsheaf Books.

Magubane, Z. (2005). Overlapping Territories and Intertwined Histories. by Adams, J., Clemens, E. and Orloff, A. (eds.) Remaking Modernity: Politics, History, and Sociology (pp. 92-108). Duke University Press.

Mahmud, T. (1999). Colonialism and Modern Constructions of Race: A Preliminary Inquiry. University of Miami Legal Review, 53:1219-1246.

Mahmud, T. (2012). Cheaper than a Slave: Indentured Labor, Colonialism and Capitalism. Seattle University School of Law Research Paper No. 12-34.

Mahoney, J. and Rueschemeyer (2003). Comparative Historical Analysis in the Social Sciences. Cambridge University Press.

Manderson, L. (1996). Sickness and the State: Health and Illness in Colonial Malaya, 1870-1940. Cambridge University Press.

Manderson, L. (1999). Public Health Developments in Colonial Malaya: Colonialism and the politics of prevention. American Journal of Public Health, 89(1):102-7.

Manning, P. (2007). Legacies of Slavery: Comparisons of Labour and Culture. In Fernandes Dias, M.S. (ed.) Legacies of Slavery: Comparative Perspectives (pp. 16-34). Cambridge Scholars Publishing.

Manickam, S.K. (2009). Common Ground. Journal of Southeast Asian Studies, 40:593612. 
Marr, M. D. (2015). Better Must Come: Exiting Homelessness in Two Global Cities. Cornell University Press.

Marr, M. (2016). Urban Welfare Regimes, Organizational Cultures, and Client-Staff Tie Activation: A Comparison of Transitional Housing Programs in Los Angeles and Tokyo. Journal of Urban Affairs, 38(2):214-235.

Maruyama’s Visits [Maruyama-Sōkan ga Furōshagai wo Shisatsu] (1930). Asahi Shimbun, December 31.

Marx, K and Engels, F. (1996). Capital: Volume One (trans. Samuel Moore and Edward Aveling). International Publishers.

Marzec, R. (2010). Empire, the Question of Representation, and the Erasure of Inhabitancy. In Nagy-Zekmi, S. and Zabus, C. (eds.) Colonization or Globalization?: Postcolonial Explorations of Imperial Expansion (pp. 3-12). Lanham.

Massey, D. (1994). Space, Place and Gender. University of Minnesota Press.

Matsuzawa, T. (2006). Tennō Teikoku no Kidō: Okami Suihai, Haigai, Haigai no Kindai Nihonshi (On a Path to Imperial Japan: A Japanese History of Okami Reverence, Adulation of the Foreign, and Anti-Alien Sentiment). Renga Shobo Shinsha.

Mattei, U. and Nader, L. (2008). Plunder: When the Rule of Law is Illegal. Blackwell Publishing.

May, J. and Cloke, P. (2014). Modes of attentiveness: Reading for difference in geographies of homelessness. Antipode, 46(4):894-920.

Mbembe, A. (2001). On the Postcolony. University of California Press.

McCann, E. (2011). Urban Policy Mobilities and Global Circuits of Knowledge. Annals of the AAG, 101(1):107-130.

McCormack, N. (2007). Civilising the urban other: poverty as a national problem. Ritsumeikan Annual Review of International Studies, 6:21-43.

McClintock, A. (1991). "No Longer in a Future Heaven: Women and Nationalism in South Africa.” Transition, 15:104-23.

McLaughlin, J. (2000). Writing the urban jungle: reading empire in London from Doyle to Eliot. University Press of Virginia.

McVeigh, B. (2004). Nationalisms of Japan: Managing and Mystifying Identity. Rowman and Littlefield Publishers. 
Mehta, U.S. (1999). Liberalism and Empire. University of Chicago Press

Metropolitan Policy Planning Office. (1995). Aratana Toshi-Mondai to Taiō no Hōkō [A New Urban Problem and Future Responses]. Metropolitan Office.

Midgley, J. (2011). Imperialism. colonialism, and social welfare. In: Midgley, J. and Piachaud, D. (eds.), Colonialism and Welfare: Social Policy and the British Imperial Legacy. (pp. 36-54). Edward Elgar.

Mignolo, W.D. (2000). Local Histories/Global Designs: Coloniality, Subaltern Knowledges, and Border Thinking. Princeton University Press.

Mignolo, W. and Tlostanova, M. (2008). The Logic of Coloniality and the Limits of Postcoloniality. In Krishnaswamy, R. and Hawley, J.C. (eds.) The Post-Colonial and the Global (pp.109-123). University of Minnesota Press.

Mills, C. (2015). The Psychiatrization of Poverty: Rethinking the Mental Health-Poverty Nexus. Social and Personality Psychology Compass, 9(5):213-222.

Ministry of Health, Labor, and Welfare (2003) Hōmuresu no Jittai ni Kansuru ZenkokuChōsa Hokokusho no Gaiyō [Summary of the Report on the National Survey of Conditions of Homelessness]. Ministry of Health, Labour, and Welfare. Retrieved from: https://www.mhlw.go.jp/houdou/2003/03/h0326-5.html

Ministry of Health, Labour and Welfare. (2016, March 11). Hōmuresu Jittai ni Kan suru Zenkoku Chōsa (Seikatsu Jittai Chōsa) no Kekka (Gaiyōhan). Retrieved from Ministry of Health, Labour and Welfare: https://www.mhlw.go.jp/file/04Houdouhappyou-12003000-Shakaiengokyoku-ShakaiChiikifukushika/01_homeless28_kekkagaiyou.pdf

Ministry of Welfare Services. (1974). Report on the Preliminary Study of Beggars and Vagrants in Sungai Patani, Kedah. Ministry of Welfare Services.

Ministry of Welfare Services. (1976). Survey on Beggars and Vagrants in Peninsular Malaysia. (unpublished) Ministry of Welfare Services.

Minister orders checks. (1996). New Sunday Times, February 17, p.15.

Mitchell, D. (1997). The annihilation of space by law: The roots and implications of antihomeless laws in the United States. Antipode, 29(3):303-335.

Mitchell, D. (2001). Postmodern geographical praxis? The postmodern impulse and the war against homeless people in the "post-justice" city. In Minca, C. (ed.) Postmodern Geography: Theory and Praxis. (pp. 57-92). Blackwell.

Mohamed Din bin Ali (1961) The Beggar Problem [Sel.Sec.2014-27], February 11. File\#1957/0301175. Arkib Negara Malaysia. 
Mohr, J. W. (2014) The classificatory logics of state welfare systems: Towards a formal analysis. In McNeely, C. (ed.), Public Rights, Public Rules: Constituting Citizens in the World Polity and National Policy (pp. 207-238). Routledge.

Moyana, J.K. (1976). The Political Economy of the Migrant Labour System: Implications for Agricultural Growth and Rural Development in Southern Africa. Africa Development 1(1): 34-41.

Murakami, C. (2005, May 22). Hōmuresu Chi'iki Seikatsu Ikō Shien Jigyō (Yoyogi Koen). Retrieved from Tokyo Homeless: https://ameblo.jp/chinamin/entry10001925378.html

Murota, H. (2017). Kanyōna-Ba to Shite no Rōjō [Tolerant Space of the Streets]. Rironto Dōtai, 10:6-23.

Murphy, S. (2009). “Compassionate” Strategies of Managing Homelessness. Antipode, 41(2):305-325.

Muzenshi. (1903). Ryōko-Byōnin niTsuite no Kenkyū [Study on Sick Travelers]. TōkyōYōikuin Gesshū, 34:3-6.

Nakanishi, Y. (2003). Meiji-Makki "Furōsha” Mondai no Shozai to Sono Rongi [Definition and Discussion of the "Vagrant" lssue in late Meiji era]. Social Welfare Studies of Aichi-Kenritsu Daigaku Bungaku Bunkazai Kenkyūjo.

Narayan, U. (1995). Colonialism and its Others: On Rights and Care Discourses. Hypatia, 10(2):133-140.

Neary, I. (1997). Burakumin in Contemporary Japan. In M. Weiner, Japan's Minorities: The Illusion of Homogeneity (pp. 59-83). Routledge.

Neocleous, M. (2000). The Fabrication of Social Order: A Critical Theory of Police Power. Pluto Press.

Ness, G.D. (1967). Bureaucracy and Rural Development in Malaysia. University of California Press.

New Straits Times. (2019, May 21). Maya Karin sees red over incompetence leading to food wastage during Ramadan. Retrieved from New Straits Times: https://www.nst.com.my/lifestyle/groove/2019/05/490262/showbiz-maya-karinsees-red-over-incompetence-leading-food-wastage

Nishikawa, M. (2006). 19-Seiki Kōhan no Eiryō Indo no Furōsha Mondai to Yōroppa-jin Furōsha-Hō [The Problem of Homelessness in Late-Nineteenth Century India and the European Vagrancy Act]. Konan Daigaku Kiyo Bungaku-hen [Konan University Bulletin of the Literature Department], 141:29-57. 
Nurbaiti Hamdan (2014). Move to curb beggars, April 9. The Star.

Obinger, J. (2009). Working on the Margins: Japan's Precariat and Working Poor. Retrieved from the Electronic Journal of Contemporary Japanese Studies at: http://www.japanesestudies.org.uk/discussionpapers/2009/Obinger.html

O’Connor, A. (2001). Poverty Knowledge: Social Science, Social Policy, and the Poor in Twentieth-Century US History. Princeton University Press.

Ocobock, P. (2006). 'Joy Rides for Juveniles': Vagrant Youth and Colonial Control in Nairobi, Kenya, 1901- 52. Social History, 31(1):42-43.

Ocobock, P. (2008). Introduction. In Beier, A.L. and Ocobock, P. (eds.) Cast Out: Vagrancy and Homelessness in Global and Historical Perspective, pp. 1-35. Ohio University.

Ogawa, A. (2015). Lifelong Learning in Neoliberal Japan: Risk, Community, and Knowledge. SUNY Press.

Oguma, E. (2002). A Genealogy of 'Japanese' Self-Images. (trans. by David Askew) Trans Pacific Press.

Oncu, A., Weyland, P. (1997). Introduction. In Oncu, A., Weyland, P. (eds.) Space, Culture and Power: New Identities in Globalizing Cities (pp. 1-20). Zed Books.

Ong, A. (2006). Neoliberalism as exception. Duke University Press.

Ooi, K. (2003). Three-Tiered Social Darwinism in Malaysian Ethnographic History. Southeast Asian Studies, 42(3):162-179.

Orinpikku Oidashi-Yamero Kokuritsu-Kyōgijō Shūhen de Kurasu Nojuku-Seikatsusha wo Ōen suru Yūshi. (2016). 9/30Meiji-Kōen Haishi (2)DaikoKōenha10km saki no Tamagawa-Ryokudō, October 2. Retrieved from Youtube: https://www.youtube.com/watch?v=kQah3X7Zaxg

Orloff, A.S. (2003). Markets Not States? The Weakness of State Social Provision for Breadwinning Men in the U.S. In: Haney, L. and Pollard, L., Families of a New World (pp.217-45). Routledge.

Orloff, A.S. (2005). Social Provision and Regulation: Theories of States, Social Policies, and Modernity. In Adams, J., Clemens, E.S., and Orloff, A.S. (eds.) Remaking Modernity: Politics, History, Sociology (pp. 92-108). Duke University Press.

O'Sullivan, E. (2012). Varieties of Punitiveness in Europe. European Journal of Homelessness, 6(2):69-97. 
Otani, S. (1948). Ikiteiru Ueno-Chikadō no Jittai [Life in Ueno's Underground]. Yujinsha.

OurPlanet-TV. (2016). Nojukusha Haijo Yamero Shinkokuritsu Kyōgijo-Yoteichi, January 8. Retrieved from YouTube: https://www.youtube.com/watch?v=C56yMSe5dDw

Over 1000 unseen [Inai koto ni sareta 1000nin kyo]. (2020). January 27. Retrieved from Mainichi Shimbun: https://mainichi.jp/articles/20200127/k00/00m/040/142000c

Park, J. (2014). Bodies for empire: biopolitics, reproduction, and sexual knowledge in late colonial Korea. Ui Sahak (Korean Journal of Medical History), 23(2):203-38.

Parmer, J. N. (1989). Health and Health Services in British Malaya in the 1920s. Modern Asian Studies, 23(1):49-71

Parsons, T. (1951). The Social System. Free Press.

Patil, V. (2017). Sex, Gender and Sexuality in Colonial Modernity: Towards a Sociology of Webbed Connectivities. In Go, J. and Lawson, G. (eds.) Global Historical Sociology (pp. 139-155). Cambridge University Press.

Peck, J. (2001). Neoliberalizing states. Progress in Human Geography, 25(3):445-455.

Peck, J. and Tickell, N. (2002). Neoliberalising space. Antipode, 34(3):380-404.

Peck, J. (2003). Geography and Public Policy. Progress in Human Geography, 27(2):222232.

Peck, J. (2011). Geographies of policy: from transfer-diffusion to mobility-mutation. Progress in Human Geography, 35(6):773-797.

Peck, J. (2015). Austerity urbanism: The neoliberal crisis of American cities. Rosa Luxemburg Stiftung.

Perlman, J. (1976). The Myth of Marginality: Urban Politics and Poverty in Rio de Janeiro. UC Press.

Piven, F. and Cloward, R. (1993). Regulating the Poor: The Functions of Public Welfare. Vintage Books.

Pleace, N. (1998). Single Homelessness as Social Exclusion: The Unique and the Extreme. Social Policy and Administration, 32(1):46-59.

Pleace, N., Burrows, R. and Quilgars, D. (1997). Homelessness in Contemporary Britain; Conceptualisation and Measurement. In Burrows, R. Pleace, N. and Quilgars D. (eds.) Homelessness and Social Policy (pp. 1-18). Routledge. 
Polanyi, K. (1944). The Great Transformation. Farrar and Rinehart.

Prisons Commissioner. (1946, July 25). Policy Regarding Vagrants. File\#1957/0620014. Arkib Negara Malaysia.

Prisons Commissioner. (1961). Beggar Problem [Prs.Pqrs.466/53], June 6. File\#2001/0069879. Arkib Negara Malaysia.

Quijano, A. (2000). Coloniality of Power, Eurocentrism, and Latin America. International Sociology, 15(2):215-232.

Raja Abdul Jalil Azman. (1958). Che Allang, September 8. File\#1957/0301175. Arkib Negara Malaysia.

Ramlan S. (1993). Raids on Vagrants Leave Little Impact. New Straits Times, October 11.

Rands, D. (2014). Function-Based Spatiality and the Development of Korean Communities in Japan. Lexington Books.

Residency Surgeon. (1894). Minutes, December 17. File\#1957/0052579. Arkib Negara Malaysia.

Resident at Ichikawa Facility Dies [Chiba Ishikaa no Fukushi Shisetsu Nyukyosha Shibō Shogai Chishi Yōgi de Kanrinin no Onna Taiho]. (2017, September 19). Retrieved from Sankei Shimbun: https://www.sankei.com/affairs/news/170919/afr1709190027-n1.html

Rigby, W. (1933). Desirability of Amending Enactment No.9. File\#1957/0272023. Arkib Negara Malaysia.

Roberts, D, and Mahtani, M (2010). Neoliberalizing Race, Racing Neoliberalism. Antipode, 42(2):248-257.

Robinson, C. J. (1983). Black Marxism: The Making of the Black Radical Tradition. University of North Carolina Press.

Robinson, F. (2016) Paternalistic Care and Transformative Recognition in International Politics. In Hayden, P. and Schick, K. (eds.) Recognition and Global Politics (pp.159-174). Manchester University Press.

Robinson, J. (2006). Ordinary cities: Between Modernity and Development. Routledge.

Robinson, J. (2011) Cities in a World of Cities. International Journal of Urban and Regional Research 35(1), 1-23. 
Robinson, W. (2014). Global Capitalism and the Crisis of Humanity. Johns Hopkins University Press.

Rodney, W. (1972). How Europe Underdeveloped Africa. Bogle-L'Ouverture Publications.

Ronald, R., and Hirayama, Y. (2009). Home Alone: The Individualization of Young, Urban Japanese Singles. Environment and Planning A: Economy and Space, 41(12):2836-2854.

Rudner, M. (1972). Draft Development Plan of the Federation of Malaya 1950-55. Journal of Southeast Asian Studies, 31(1):63-96.

Rusche, G. and Kirchheimer, O. (1968). Punishment and Social Structure. Columbia University Press.

Rusenko, R.M. (2018). Imperatives of Care and Control in Homelessness Regulation in Kuala Lumpur: 1880s to Present. Urban Studies.

Rusenko, R.M and Loh, D.Y. (2014). Begging, the Destitute Persons Act 1977, and punitive law: An exploratory survey. Paper presented by at the University of Malaya Seminar on Homelessness in Kuala Lumpur, Malaysia.

Rutland, T. (2010). The Financialization of Urban Redevelopment. Geography Compass, 4/8:167-1178.

Ryan, K. (2007). Social Exclusion and the Politics of Order. Manchester University Press.

Sabri, S., and Yakuup, A. (2008). Multi-Criteria Expert Based Analysis for Ranking the Urban Gentrification Drivers in Developing Countries. Paper presented at the 2nd International Conference on Built Environment in Developing Countries. Retrieved at: http://eprints.usm.my/34862/1/HBP12.pdf

Saitama Sōgō Hōritsu Jimusho. (2017). Hinkon Bijinesu no Ihōsei o Mitome Sōgaku Yaku-1580 Man-en no Songai Baishōtō o Meijiru, March 1. Retrieved from Saitama Sōgō Hōritsu Jimusho: https://saitamasogo.jp/archives/69382

Sake and Women [Sake-to-Onna]. (1926). Yomiuri Shinbun. July 1.

Said, E. (1977). Orientalism. Penguin.

Sanada, M. (1940). Shina-Kojiki [Chinese Beggar]. Manshū-gurafu, 8(3):73.

Sandhu, K.S. (1969). Indians in Malaya: Some Aspects of Their Immigration and Settlement (1786-1957). Cambridge University Press. 
Sanya Taisaku Office. (1976). San’ya ni Okeru Kōrei-Rōdōsha no Jittai to Taisaku. Tokyo Metropolitan Archives: Fukushi-A280

Sasanuma, H. (2008). Hōmuresu to Jiritsu/Haijo [Homeless and SelfReliance/Exclusion]. Otsuki Shoten

Sassen, S. (1990). The Global City: New York, London, Tokyo. Princeton University Press.

Skolnik, T. (2018). How and Why Homeless People Are Regulated Differently. Queen's Law Journal, 43(2):297-324.

Sechiyama, K. (2013). Patriarchy in East Asia. Brill.

Seidman, S. (1997). Difference Troubles: Queering Social Theory and Sexual Politics. Cambridge Cultural Social Studies.

Selangor Journal. (1896). The Selangor Journal, Volume 4. Selangor Printing.

Selangor State. (1902). Rules Made by the Resident. File\#1957/0101382. Arkib Negara Malaysia.

Shibata, S. (2016). Resisting Japan's Neoliberal Model of Capitalism: Intensification and Change in Contemporary Patterns of Class Struggle. British Journal of Industrial Relations, 54(3):496-521.

Shima, K. (1999). Gendai Nihon no Nojuku Seikatsusha [Street Sleepers in Modern Japan]. Gakubunsha.

Shimokawa, P. (2013). Recent changes in forced evictions and homelessness in Japan. HIC-HLRN. Retrieved from:

http://www.hlrn.org/activitydetails.php?id=o3FtZA==\#.XojRF3IpD9M

Shinagawa Welfare Office. (1955). Furōsha Kōsei Shisetsu Toritsu-Hamakawaryō. Tokyo Metropolitan Archives: Fukushi-B325.

Shinjuku Ward. (2006). Shinjuku-ku Hōmuresu no Jiritsu-Shiento ni Kan suru SuishinKeikaku.[Implementation Plans for Shinjuku Ward Self-Reliance Support]. Shinjuku Ward. Retrieved from https://www.city.shinjuku.lg.jp/content/000041544.pdf; also, https://www.city.shinjuku.lg.jp/fukushi/file04_02_00005.html

Shinjuku Ward. (2013). Dai-2 Kai Sakutei-I’inkai Shiryō [Reference Materials for the Second Policy Review Committee]. Shinjuku Ward. Retrieved from http://www.city.shinjuku.lg.jp/content/000147274.pdf

Shirahase, S. (2014). Social Inequality in Japan. Routledge. 
Sibley, D. (1995). Geographies of Exclusion. Routledge.

Siddle, R. (2004). With shining eyes: Ainu protest and resistance, 1869-1945. In Weiner, M. (Ed Race, Ethnicity and Migration in Modern Japan (pp. 337-375). London and Routledge.

Sigman, R. and Lindberg, S.I. (2019). Democracy for All: Conceptualizing and Measuring Egalitarian Democracy. Political Science Research and Methods, 7(3):595-612.

Silver, A. (1967). The demand for order in civil society: a review of some themes in the history of urban crime, police and riot. In Bordua, D.J. (ed.) The Police: six sociological essays (pp. 57-82). Wiley.

Simeon, R., and Ikeda, Y. (2003). The Hollowing Out Phenomenon in Japan. Journal of Business \& Economics Research (JBER), 1(6):1-12.

Snow, D.A. and Anderson, L. (1987). Identity Work Among the Homeless: The Verbal Construction and Avowal of Personal Identities. American Journal of Sociology, 92(6):1336-71.

Smith, N. (1996). The New Urban Frontier. Psychology Press.

Smith, N. (2002). New Globalism, New Urbanism. Antipode 34(3):427-450.

Social Welfare Department. (1955). Beggars in the Federation of Malaya. Caxton Press.

Social Welfare Department. (1955). Beggars in the Federation of Malaya. Caxton Press Ltd.

Social Welfare Ministry. (n.d.) Draft Memorandum. File\#2001/0069879. Arkib Negara Malaysia.

Soejima, N. (2014). Meiji-Zenki ni Okeru Furōsha/Kojiki no Fukushiteki-Shogū [Early Meiji Treatment of Vagrants and Beggars]. Shakai-Fukushi, 55:173-186.

Somers and Roberts. (2008). Toward a New Sociology of Rights: A Genealogy of "Buried Bodies" of Citizenship and Human Rights. Annual Review of Law and Social Science, 4:385-425.

Snow, D.A. and Mulcahy, M. (2001). Space, Politics, and the Survival Strategies of the Homeless. American Behavioral Scientist, 45:149-169.

Sparks, T. (2012). Governing the Homeless in an Age of Compassion. Antipode, 44(4):1510-1531. 
Spivak, G.C. (1988). Can the Subaltern Speak? In Nelson, C. and Grossberg, L. (eds.) Marxism and the Interpretation of Culture (pp. 271-313). Macmillan Education.

Spivak, G.C. (2008). Other Asias, Blackwell.

Stauts, H.C. (2000) Parens Patriae. Journal of the Center for Children and the Courts, 2(139):139-152.

Steinmetz, G. (2013). A child of the empire: British sociology and colonialism, 1940s1960s. Journal of the History of the Behavioral Sciences, 49(4):353-78.

Stenson, M.R. (1980). Class, Race, and Colonialism in West Malaysia: The Indian Case. University of Queensland Press.

Stevens, Q., Kozlowski, M., and Ujang, N. (2016). Contrasting Global Imagery to Local Realities in the Postcolonial Waterfronts of Malaysia's Capital Cities. International Journal of Architectural Research, 10(1):240-256.

Stewart, F. (2000). Crisis Prevention: Tackling Horizontal Inequalities. Oxford Development Studies, 28(3):245-262.

Stoler, A.L. (1995). Race and the Education of Desire: Foucault's History of Sexuality and the Colonial Order of Things. Duke University Press.

Stoler, A.L. (2002). "Colonial Archives and the Arts of Governance." Archival Science 2 (1-2): 87-109.

Stoler, A.L. (2006). Haunted by Empire. Duke University Press.

Stoler, A.L. (2008). Imperial Debris. Cultural Anthropology 23(2):191-221.

Stoler, A.L. (2009). Along the Archival Grain. Princeton University Press.

Stone, D. (2008). Global Public Policy, Transnational Policy Communities, and Their Networks. Policy Studies Journal, 36(1):19-38.

Stringer, E. (2007). Action Research. London: Sage Publications.

Stuart, F. (2016). Down, Out and Under Arrest: Policing and Everyday Life in Skid Row. University of Chicago Press.

Susser, I. (1996). The Construction of Poverty and Homelessness in US Cities. Annual Review of Anthropology, 25:411-435.

Suzuki, M., Ito, M., Ishida, M., Nihei, N., and Maruyama, M. (2010). Individualizing Japan: searching for its origin in first modernity. The British Journal of Sociology, 61(3):513-538. 
Swarr, A. (2012). Sex in Transition: Remaking Gender and Race in South Africa. SUNY Press.

Syafiq S. and Selvaratnam, D.P (2018). Strategi Kelangsungan Hidup Gelandangan di Pusat Bandaraya Kuala Lumpur [The Homeless' Survival Strategy in Kuala Lumpur City]. Sains Humanika, 10(2):19-29.

Sylvestre, M. (2013). Narratives of Punishment. European Journal of Homelessness, 7(2):363-369.

Takenaka, R. (1969). San’ya: Toshi-Hanron no Genten [San’ya: Source of Urban Revolt]. Marusan Bunko.

Think City. (2019). Registry Week Report, May 27. Retrieved from: https:/thinkcity.com.my/wp/wp-content/uploads/2019/09/2019_05_21-RegistryWeek-Report.pdf

Tierney, R. (2010). Tropics of savagery: the culture of Japanese empire in comparative frame. University of California Press.

Tilly, C. (1985). War Making and State Making as Organized Crime. In Evans et al. (eds.) Bringing the State Back In (pp. 169-186). Cambridge University Press.

Tilly, C. (1993). Coercion, capital and European states, A.D. 990-1992. Penguin.

Tilly, C. (1998). Durable Inequality. University of California Press.

Tilly, C. (2007). Democracy. Cambridge University Press.

Tokubetsu-ku Kyōgikai. (2017). Tokubetsu-kusei Kenkyū 8: Rojō-Seikatsusha Mondai ni Kan suru Toku Kentōkai. 2017 Research Report.

Tokyo Bar Association. (2016). Jinken-Shingai Kyusai-Moshitate Jiken niTsuite, March 28. Retrieved from Tokyo Bar Association: https://www.toben.or.jp/message/20160328.pdf

Tokyo Metropolitan Government (TMG) Construction Bureau. (2004). Pāku Manejimento Masutā Puran [Park Management Master Plan]. Tokyo Metropolitan Construction Bureau.

TMG Construction Bureau. (2011). Toritsu Koen to no Shitei Kanrisha no Kanri Unei Jyōkyō ni Tai suru Hyōka. Retrieved from Tokyo Metropolitan Government Construction Bureau: https://www.kensetsu.metro.tokyo.lg.jp/hyouka/pdf/20hyouka_kouen.pdf 
TMG Construction Bureau. (2016). Hōmuresu Taisaku Manyuāru - Kōen no Kanri Tekiseika [Homeless Measures Manual on Improving Management in Parks]. Tokyo Metropolitan Construction Bureau.

TMG Construction Bureau. (2017). 23-nen Shitei Kanrisha Kanri Unei Jyōkyō Hyōka . Retrieved from Tokyo Metropolitan Government Construction Bureau: https://www.kensetsu.metro.tokyo.lg.jp/content/000000711.pdf

Tokyo Metropolitan Government. (n/d). City Planning Vision for Tokyo: Special Urban Renaissance Districts. Retrieved from Tokyo Metropolitan Government: https://www.toshiseibi.metro.tokyo.lg.jp/pdf_e/015.pdf

Tokyo’s Maggots [Tōkyō-no-Uji]. (1891). Yomiuri-Shimbun. August 26.

Tokyo Social Bureau. (1928). Hiyatoi-Rōdōsha no Nikki [Day Laborers’ Diaries]. Tokyo Social Bureau.

Trundle, C. and Kaplonski, C. (2011) Tracing the political lives of archival documents. History and Anthropology 22(4):407-414.

Tsu, T. (2010). Japan's “Yellow Peril”: The Chinese in Imperial Japan and Colonial Korea. Japanese Studies, 30(2):161-183.

Vagrancy Bill. (1906). The Eastern Daily Mail and Straits Morning Advertiser, January 20, p.2.

Vorspan, R. (1977). Vagrancy and the New Poor Law in Late-Victorian and Edwardian England. The English Historical Review, 92(362):59-81.

Vorspan, R. (1977). Vagrancy and the New Poor Law in Late-Victorian and Edwardian England. The English Historical Review, 92(362):59-81.

Wacquant, L. (2001). The Penalisation of Poverty and the Rise of Neo-Liberalism. European Journal on Criminal Policy and Research, 9:401-412.

Wacquant, L. (2009). Punishing the Poor: The Neoliberal Government of Social Insecurity. Duke University Press.

Walby, K., and Lippert, R. (2012). Spatial regulation, dispersal, and the aesthetics of the city: Conservation officer policing of homeless people in Ottawa, Canada. Antipode, 44(3):1015-1033.

Waldron, J. (1992). Homelessness and the Issue of Freedom. UCLA Law Review 39(1):295-324.

Waley, P. (2007). Tokyo-as-World-City: Reassessing the Role of Capital and the State in Urban Restructuring. Urban Studies, 44(8):1465-1490. 
Wallerstein, I. (2006). World-Systems Analysis: An Introduction. Duke University Press.

Wasserman, JA. and Clair, J.M. (2010). At home on the street: people, poverty, and a hidden culture of homelessness. Lynne Rienner Publishers.

Watson, M. (2014). Tokyo Ainu and the Urban Indigenous Experience. In M. L. Hudson, Beyond Ainu Studies (pp. 69-85). University of Hawaii Press.

Watson, S. and Austerberry, H. (1986). Housing and Homelessness: A Feminist Perspective. Routledge and Kegan Paul.

Weber, R. (2002). Extracting Value from the City. Antipode 34(3):519-540

Weiner, M. (1997). The Invention of Identity: Race and Nation in Pre-War Japan. In Dikotter, F. (ed.) The Construction of Racial Identities in China and Japan (pp. 96-117). University of Hawaii Press.

Welch, J. (1894). "Prison Ward" [No.3130/94], November 22. File\#1957/0052579. Arkib Negara Malaysia.

Welfare Council. (1956). Social Work in Japan. Zenkoku Shakai-Fukushi Kyōgikai.

Welfare Services Ministry. (1975). Survey on Beggars and Vagrants. Welfare Services Ministry.

Wellington, A. (1927). Hygiene and Public Health in Japan, Chosen and Manchuria. Report on Conditions Met with During the Tour of the League of Nations Interchange of Health Officers. Federated Malay States Government Printing Office.

Whiteford, M. (2010). Hot Tea, Dry Toast and the Responsibilisation of Homeless People. Social Policy and Society, 9(2):193-205.

Willse, C. (2010). Neo-liberal biopolitics and the invention of chronic homelessness. Economy and Society, 39:2, 155-184.

Willse, C. (2015). The Value of Homelessness: Managing Surplus Life in the United States. University of Minnesota Press.

Wolch, J. and Dear, M. (1993). Malign neglect: Homelessness in an American city. Jossey-Bass.

Woollacott, A. (2006). Gender and Empire. Palgrave Macmillan.

Yamada, S. (2008). Jichitai-Hōmuresu-Taisaku niMiru Hōmuresu-Taisaku no Kadai [Lessons from Local Homelessness Measures]. Chingin to Shakai-Hōshō, 1468:18-31. 
Yamada, S. (2016). Muryōteikaku-Shukuhakusho no Kenkyū [Research on Free and Low-Cost Accommodations]. Akashi Shoten.

Yamamuro, G. (1925). Shakaijigyōka no Yōsei. Central Social Work Association.

Yasui, S. (1933). Shakai-Mondai to Shakai-Jigyō [Social Issues and Social Work]. Sanseido.

Yeager, P.C. (1993). The Limits of Law: The Public Regulation of Private Pollution. Cambridge University Press.

Yeager, P.C. (1995). Law, Crime and Inequality: The Regulatory State. In Hagan, J. (ed.) Crime and Inequality. Stanford University Press.

Yokairei. (1892). Asahi Shimbun, January 30.

Young, I.M. (200). Structural injustice and the politics of difference. In Christiano, T. and Christman, J. (eds.) Contemporary Debates in Political Philosophy. WileyBlackwell. 
VITA

\section{RAYNA MARLENE RUSENKO}

Born, Syracuse, New York

1993-1997

B.A., Asian Studies

Occidental College

Los Angeles, California

2011-2013

Master of Public Policy

University of Malaya

Kuala Lumpur, Malaysia

2014-2016

MA-Asian Studies

Florida International University

Miami, Florida

2014-2020

Doctoral Candidate

Florida International University

Miami, Florida

\section{PUBLICATIONS AND PRESENTATIONS}

Rusenko, R. (2020) Homelessness Regulation and Neoliberalism's Imperial Past: The Janus Face of Anti-Homeless Urbanism and Tokyo's Modern Socio-Spatial Development. Antipode 52(6).

Rusenko, R.M. (August, 2019) When Policy Narratives Collide: Challenges in Making Policy Work for Housing Insecure Populations. Panel presentation, with Ananti Rajasingham and Jerry Teo at the International Conference on Emerging Issues in Public Policy: Kuala Lumpur, Malaysia.

Rusenko, R.M. (2018) Imperatives of Care and Control in Homelessness Regulation in Kuala Lumpur. Urban Studies 55(10): 2123-2141.

Rusenko, R.M. (July, 2018) The Relationship of Public Policy to Gentrification and Displacement of Homeless Persons: Modern Tokyo and 150 Years of Vagrancy Measures. Paper presented at the Special Meeting of the Human Geographical Society of Japan: Tokyo.

Rusenko, R.M. (January, 2018) Legacies of Vagrancy Law in Contemporary Homelessness Regulation: Findings. Research presented at the Japan Foundation Fellows Meeting: Tokyo. 
Rusenko, R.M (August, 2016) Race, Class, and Gender in Homelessness Regulation in Kuala Lumpur, 1870-1930. Paper presented at the American Sociological Association Annual Meeting: Seattle, Washington.

Rusenko, R.M. (June, 2015) Homelessness and Related Policies in Japan and Malaysia. Invited presentation at the Institute of Global Homelessness and DePaul University Conference on Homelessness in a Global Landscape: Chicago, Illinois.

Rusenko, R.M and Loh, D.Y. (October, 2014) Begging, the Destitute Persons Act 1977, and punitive law: An exploratory survey. Paper presented by at the University of Malaya Seminar on Homelessness in Kuala Lumpur, Malaysia.

Rusenko, R.M. (2014) Homelessness, Human Insecurities, and the Government Agenda in Malaysia: The Simultaneous Inclusion and Exclusion of Anjung Singgah. Asian Journal of Social Sciences 42(1):45-74.

Rusenko, R.M. (2014) Violating the Constitutional and Human Rights of Homeless Persons: Anti-vagrancy Measures and the Destitute Persons Act. In Suara Inisiatif (ed.) Malaysia Human Rights Report 2013: Civil and Political Rights, pp. 185-192. Suaram.

Rusenko, R.M. (August, 2013) The Anjung Singgah Strategy. Paper presented at the American Sociological Association Annual Meeting: New York, New York.

Rusenko, R.M. (January, 2013) Hasil Kajian Mengenai Anjung Singgah Dan Golongan Gelandangan (Report on Anjung Singgah and Homelessness). Paper presented at Malaysian Ministry of Women, Family, and Community Development: Putra Jaya, Malaysia.

Rusenko, R.M. (December, 2012) Human Insecurity and Street Homelessness. Paper presented at the 10th ASEAN Inter-University Conference on Social Development: Brunei Darussalam, Brunei. 